\title{
IUCN
}

Enhancing food security through forest landscape restoration: Lessons from Burkina Faso, Brazil, Guatemala, Viet Nam, Ghana, Ethiopia and Philippines
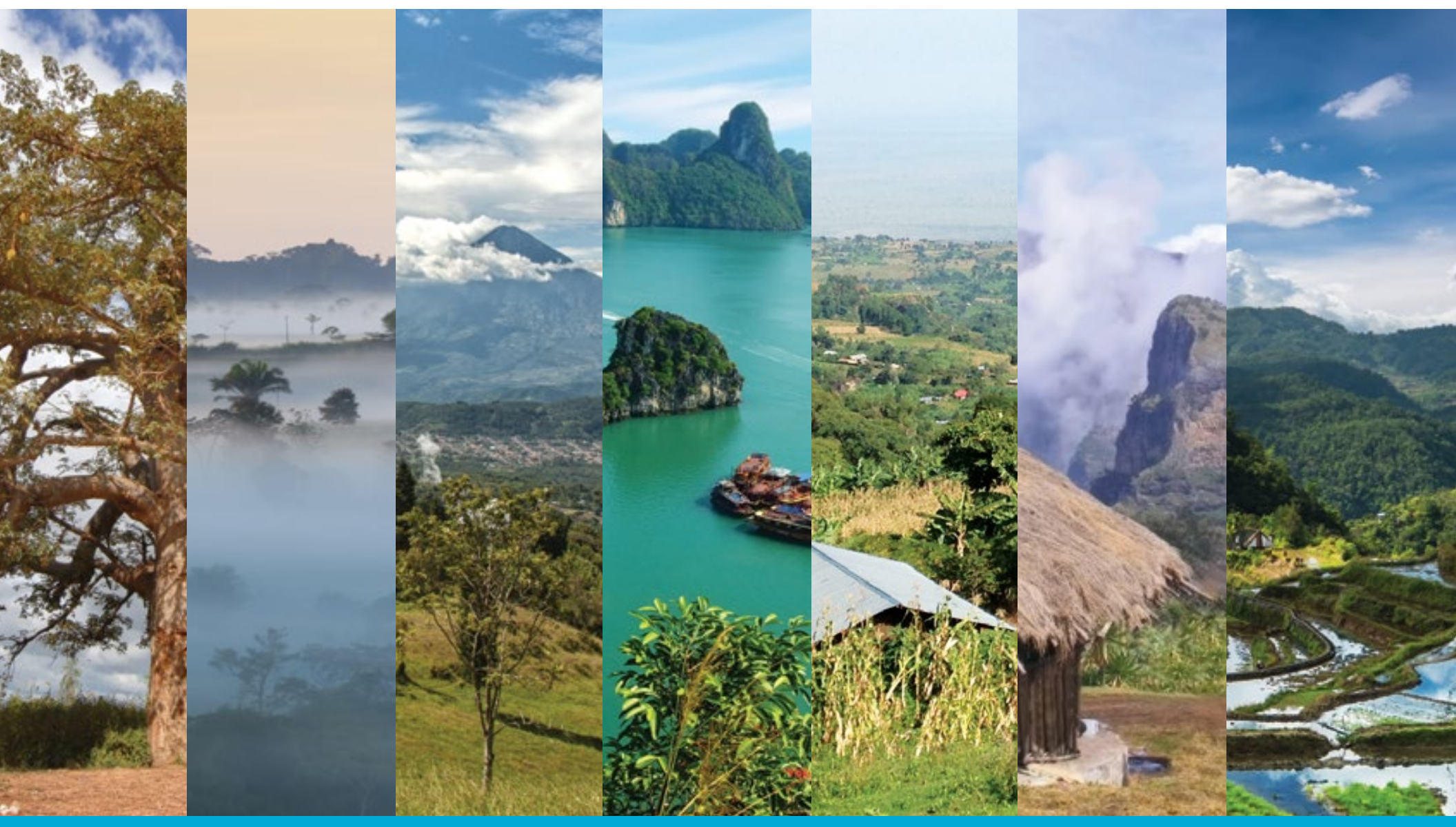


\section{Enhancing food security through forest landscape restoration: Lessons from Burkina Faso, Brazil, Guatemala, Viet Nam, Ghana, Ethiopia and Philippines}


The designation of geographical entities in this book, and the presentation of the material, do not imply the expression of any opinion whatsoever on the part of IUCN concerning the legal status of any country, territory, or area, or of its authorities, or concerning the delimitation of its frontiers or boundaries.

The views expressed in this publication do not necessarily reflect those of IUCN.

This publication has been made possible in part by funding from UK Department for International Development (DFID).

Published by: IUCN, Gland, Switzerland

Copyright: @ 2015 International Union for Conservation of Nature and Natural Resources

Reproduction of this publication for educational or other non-commercial purposes is authorized without prior written permission from the copyright holder provided the source is fully acknowledged.

Reproduction of this publication for resale or other commercial purposes is prohibited without prior written permission of the copyright holder.

Citation: Kumar, C., Begeladze, S., Calmon, M. and Saint-Laurent, C., (eds.). (2015). Enhancing food security through forest landscape restoration: Lessons from Burkina Faso, Brazil, Guatemala, Viet Nam, Ghana, Ethiopia and Philippines. Gland, Switzerland: IUCN. pp. 5-217.

Djenontin, I. and Djoudi, H. (2015). 'From degraded to functional restored forest land: Smallholder farmers curbing food insecurity in central Burkina Faso.' In: Kumar, C., Begeladze, S., Calmon, M. and Saint-Laurent, C., (eds.). Enhancing food security through forest landscape restoration: Lessons from Burkina Faso, Brazil, Guatemala, Viet Nam, Ghana, Ethiopia and Philippines, pp. 18-41. Gland, Switzerland: IUCN.

Gomes, C., Garcia, E., Alves, E. and Queiroz, M. (2015). 'Cocoa agroforestry system as an alternative for degraded pastureland restoration, food security and livelihoods development among smallholders in a Brazilian Amazon agricultural frontier.' In: Kumar, C., Begeladze, S., Calmon, M. and Saint-Laurent, C., (eds.). Enhancing food security through forest landscape restoration: Lessons from Burkina Faso, Brazil, Guatemala, Viet Nam, Ghana, Ethiopia and Philippines, pp. 42-69. Gland, Switzerland: IUCN.

Maradiaga, J. (2015). 'Agroforesty system kuxur rum enhancing food and nutritional security in Guatemala.' In: Kumar, C., Begeladze, S., Calmon, M. and Saint-Laurent, C., (eds.). Enhancing food security through forest landscape restoration: Lessons from Burkina Faso, Brazil, Guatemala, Viet Nam, Ghana, Ethiopia and Philippines, pp. 70-105. Gland, Switzerland: IUCN.

Cuc, N. (2015). 'Mangrove forest restoration in northern Viet Nam.' In: Kumar, C., Begeladze, S., Calmon, M. and Saint-Laurent, C., (eds.). Enhancing food security through forest landscape restoration: Lessons from Burkina Faso, Brazil, Guatemala, Viet Nam, Ghana, Ethiopia and Philippines, pp. 106-121. Gland, Switzerland: IUCN.

Nunoo, I., Darko, B. and Owusu, V. (2015). 'Restoring degraded forest landscape for food security: Evidence from cocoa agroforestry systems, Ghana.' In: Kumar, C., Begeladze, S., Calmon, M. and Saint-Laurent, C., (eds.). Enhancing food security through forest landscape restoration: Lessons from Burkina Faso, Brazil, Guatemala, Viet Nam, Ghana, Ethiopia and Philippines, pp. 122-143. Gland, Switzerland: IUCN.

Weldesemaet, Y. (2015). 'Economic contribution of communal land restoration to food security in Ethiopia: Can institutionalization help?' In: Kumar, C., Begeladze, S., Calmon, M. and Saint-Laurent, C., (eds.). Enhancing food security through forest landscape restoration: Lessons from Burkina Faso, Brazil, Guatemala, Viet Nam, Ghana, Ethiopia and Philippines, pp. 144-173. Gland, Switzerland: IUCN. 
Gregorio, N., Herbohn, J., Harrison, S., Pasa, A., Fernandez, J., Tripoli, R. and Polinar, B. (2015). 'Evidencebased best practice community-based forest restoration in Biliran: Integrating food security and livelihood improvements into watershed rehabilitation in the Philippines.' In: Kumar, C., Begeladze, S., Calmon, M. and Saint-Laurent, C., (eds.). Enhancing food security through forest landscape restoration: Lessons from Burkina Faso, Brazil, Guatemala, Viet Nam, Ghana, Ethiopia and Philippines, pp. 174-217. Gland, Switzerland: IUCN.

ISBN: 978-2-8317-1757-9

DOI: http://dx.doi.org/10.2305/IUCN.CH.2015.FR.2.en

Artwork, graphics, layout and design by: Vanesa Prodanovic

Cartography by: Nieves López Izquierdo and Federico Labanti

Cover photos: IUCN/Aaron Reuben, Shutterstock.com (Copyright: africa924, Joakim Lloyd Raboff, PhotoSky, ANDRE DIB, Perfect Lazybones, Igor Plotnikov)

Available from:

IUCN (International Union for Conservation of Nature)

Global Forest and Climate Change Programme

Rue Mauverney 28

1196 Gland, Switzerland

Tel +41229990000

Fax +41229990002

GFCCP@iucn.org

www.iucn.org/knowledge/publications_doc/publications/

\section{Acknowledgements}

These seven case studies were selected through a call by IUCN for abstracts on "Enhancing food security through forest landscape restoration" and have been developed through collective inputs from IUCN's partners and colleagues. External reviewers have also provided extensive input into the analysis and rationale of each case study. Special thanks to all authors for their contribution to research, comprehensive analysis and collaboration on this joint effort.

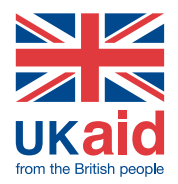

This report was produced as part of the KNOWFOR program, funded by UKaid from the UK government. 



\section{Introduction}

For several decades, forest landscape restoration (FLR) has been used as an integrated approach to improve the resilience of landscapes and the livelihoods they support. In our resource-constrained world, under the threat of climate change, restoring degraded ecosystems is key to safeguarding natural capital and ensuring food and nutrition security.

Some progress has been made towards achieving global hunger targets, as the number of undernourished people has fallen to under 800 million from between the time of the World Food Summit in 1996 through the era of the Millennium Development Goals to 2015. However, as we transition to the new Sustainable Development Agenda (20152030) the fight against eradicating hunger continues as about 795 million people globally still remain undernourished, 780 million of whom live in developing countries (FAO, IFAD, WFP, 2015). Poverty is a key indicator of hunger. But poverty is the result of unresolved global challenges - whether conflict, sluggish economic development, climate change, rising food prices, overharvested ecosystems or weather-induced disasters - that underlie economic growth and development and must be addressed to foster global sustainability and ensure food security. Alongside these challenges, the current world population is projected to increase from 7.2 billion to 9.6 billion by 2050 (UN DESA, Population Division, 2015) placing continuing pressure on already depleting natural resources. The majority of the world's poor live in rural areas in low-income countries where agriculture remains the main source of income and employment for about 2.5 billion people (IFPRI, 2015). Future agricultural production will have to rise to meet this growing demand for food.

It is well known that climate change threatens global food systems, with plenty of evidence worldwide indicating an increase in droughts and a decrease in crop yields. According to current projections, if the world becomes warmer than the current trend by 2050, the decline in crop yields will be further exacerbated. Without the capacity for mitigating climate change, it will become even more difficult to expand and intensify food production due to water scarcity and land degradation.

There are more than 2 billion hectares of deforested and degraded land globally (GPFLR, 2013) directly affecting 1.5 billion people (UNCCD, 2014). Global deforestation accounts for about 20 per cent of global greenhouse gas emissions. Currently, about $25 \%$ of total global emissions arise from the land use sector and about $40 \%$ of the world's agricultural land is already degraded. Land degradation affects the functionality and productivity of 
food systems, on which we depend for livelihoods. Population pressure and the expansion and intensification of agricultural practices, along with the impacts of climate change, pose a range of threats to the security of food, energy, water and resources. Meeting the global demand for food, either through agriculture expansion or agricultural intensification without taking environmental risks is very challenging. Massive loss of forests and land degradation are evident across the world. Reducing the current trend in deforestation and land degradation will require economic incentives, and change in practices and policies that induce preservation and conservation and encourage restoration of forest and forest landscapes.

FLR is a coherent approach that has the potential to mitigate the underlying conditions of erosion, soil degradation and nutrient depletion, and enhance the opportunity for obtaining greater output from degraded land. It is a long-term process of regaining ecological functionality and enhancing human well-being across deforested or degraded forest landscapes. It focuses on restoring forest functionality: that is, the goods, services and ecological processes that forests can provide at the broader landscape level, as opposed to solely promoting increased tree cover at a particular location (Maginnis \& Jackson, 2002). It is not just about planting trees - it involves tailoring the solution to the context in order to bring back or improve the productivity of landscapes that are deforested or degraded so they can sustainably meet the needs of people.

There is increasing evidence that FLR interventions deliver multiple benefits to the environment and society. The framework offers a wide range of restoration options based on the characteristics of each agro-ecological zone. For example:

If the land, due to deforestation or degradation, requires increasing forest cover, then a suitable intervention could be to plant forests and woodlots, or undertake silviculture or natural regeneration to increase the number of trees in an area. This is highly important for approximately 1.6 billion forest-dependent people worldwide who in some way depend on high-economic value tree species for income generation, fuelwood, timber, medicines and fruit; for high nutrition intake as well as enhancing habitat.

For degraded agricultural land, improved fallow or agroforestry practices are suitable for bringing back the biological productivity of the land by increasing soil fertility, enhancing water retention and improving crop productivity. This can directly benefit more than 1 billion people who practice such farming systems.

Because FLR involves entire landscapes in all jurisdictions, it also offers watershed protection and enhancement of mangroves along coastal areas. Mangrove restoration not only tends to safeguard the coastal areas against weather-induced catastrophic events but 
also improves the livelihoods of coastal communities. At a watershed level, FLR enhances groundwater levels while protecting downstream communities and hydraulic infrastructure.

In addition to these social and ecological benefits, FLR's long-term benefit to the environment is its potential for carbon sequestration.

\section{Enhancing food security through forest landscape restoration: Seven case studies}

The case studies from Brazil, Burkina Faso, Ethiopia, Ghana, Guatemala, the Philippines and Viet Nam highlight how FLR interventions enhance food security. They illustrate the 'win-win' solutions that can enhance land functionality and productivity, develop resilient food systems and explore the long-term potential outputs and enabling conditions for FLR interventions. A greater emphasis on the impacts of degradation and deforestation and other indicators are exemplified throughout these case studies in order to better understand the results from FLR interventions and their relationship to land productivity. The case studies offer a number of key findings.

In Burkina Faso, natural resources constitute the main source of employment and revenue, and for the poorest households, forests and tree resources play an important role in coping with food scarcity. In 2001, an FLR approach evolved in areas where forest resources were depleting, particularly in the central and northern parts of the country. These investments in soil and water conservation have led to restoring the productivity of degraded land for agriculture and have generated new agroforestry parklands as a co-benefit. The land restoration activities developed by Tiipaalga involve assisted natural regeneration of tree resources to increase availability of forest and agricultural products, as well as increasing biodiversity across three provinces of central Burkina Faso: Kadiogo, Kourweogo and Oubritenga. The results indicate that smallholders, who restored lands, are able to harvest on average six different products, ranging from non-timber forest products (NTFPs) used for food to non-edible forest products, fodder for livestock, small wildlife, and crops including cereals and legumes. This case study provides evidence that small-scale reforested lands offer an appropriate strategy and means of diversification of food sources to help curb food deficits in the months before the major harvest of food grains. Furthermore, most of the farmers perceived that the restored forest lands function as a safety net and they have seen improvements in soil fertility regeneration, biodiversity regeneration, and erosion reduction in the restored areas.

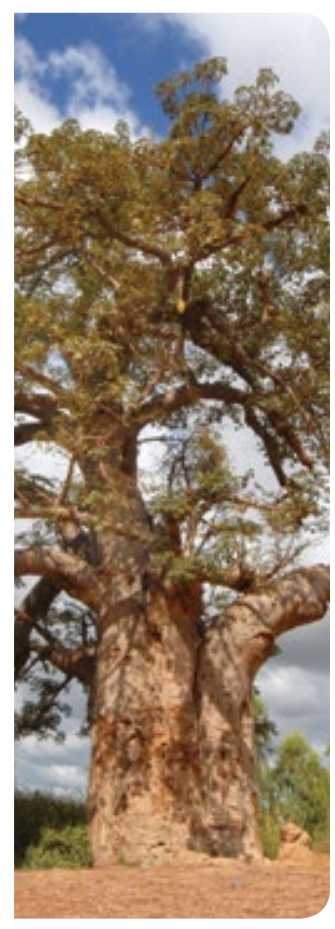




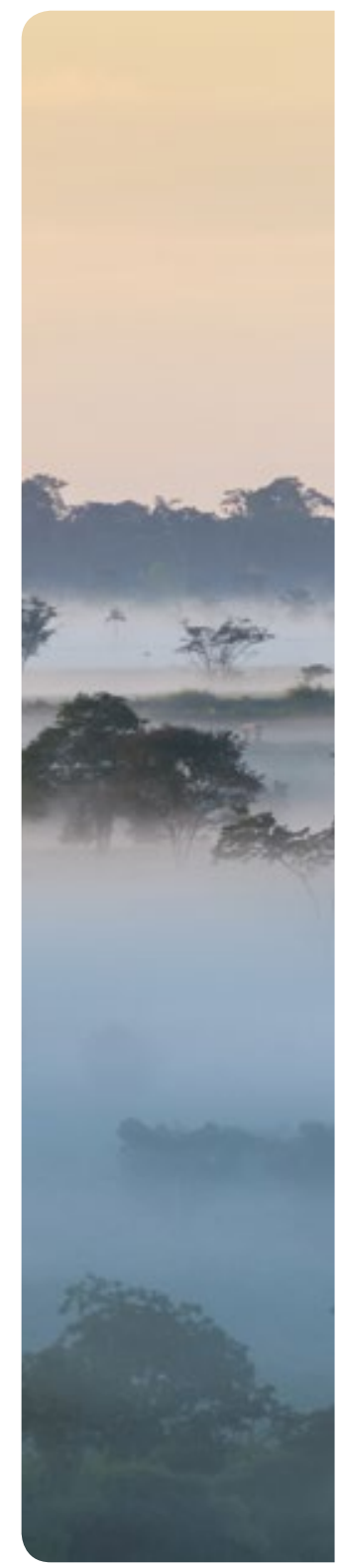

In the last few decades human activities have rapidly depleted natural resources in the Brazilian Amazon, leading to the loss of forest and related ecosystem services. Nearly $60 \%$ of the deforested area was converted into pasturelands, and the lack of proper livestock management practices resulted in degradation and abandonment of approximately 10 million hectares. To find ecological, economic and food security alternatives for small landholders, from 2011, restoration of degraded pastures has been implemented with cocoa (Theobroma cacao)-based agroforestry systems in São Félix do Xingu (SFX), located in the eastern portion of the Brazilian Amazon. The adoption of cocoa-based agroforestry generated significant environmental benefits. Among the initial annual crops, cassava (Manihot esculenta) and maize (Zea mays) stood out for their important role in food security for family-based farming. All farmers who have chosen banana trees (Musa sp.) due to their provisional shading role for cocoa generated income for three to five years before the cocoa started to produce.

The choice of species was also based on the farmer's socioeconomic profile: the most favoured fruit tree species were açaí (Euterpe oleracea) for growing regional market demand and golosa (Chrysophyllum cuneifolium (Rudge) A.C.D.) for pulp and juice. Due to market demand for its seeds, mahogany (Swietenia macrophylla) was the farmers' most preferred species while copaiba (Copaifera spp.) and andiroba (Carapa guianensis) were also highlighted as commercially valuable for the extraction and sale of oil. Given that the cocoa trees were, at most, two years old at the time of the case study, no economic return from them had yet been generated. However, the implementation of a cocoa-based agroforestry system has allowed the generation of income from other initial crops, particularly cassava, maize, banana and other fruit-bearing shade trees. This potential for diversifying income generation was an essential strategy for managing the risks of family farming production systems, ensuring an important economic return at the initial phase of the project. In the current socioeconomic context, cocoa-based agroforestry represents a profitable longterm alternative, with a range of 1.5 to 10 hectares planted per farm, an income between US\$ 3,750 and US\$ 25,000 per year per farm, plus revenue from fruits, woods and oils. Because cocoa is a global, high-demanded commodity with an established market chain and the potential for high economic return, we believe that this case study presents a promising opportunity for restoration while strengthening food security among small-scale farmers in critical Amazon development frontiers today. 
The Ethiopia case study demonstrates that institutionalizing community-based natural resource management and investing in restoration interventions and their proper planning management are vital to achieving food security. The results from this study show that restoration of communal areas can substantially improve the economic capacity of rural beneficiaries and thereby ensure their food security. This case study further suggests that instead of initiating small-scale restoration initiatives, economically viable large-scale landscape restoration initiatives are better, especially when large-scale communal land holdings are widely available in the country. Furthermore, if communal area beneficiaries are institutionalized and given the proper tools and incentives to restore their communal areas, the beneficiaries can effectively ensure their food security and sustain their livelihoods.

Cocoa production is an essential component of rural livelihoods and its cultivation is considered a 'way of life' in rural communities in Ghana. This case study presents an overview of the food production and FLR potential of cocoa agroforestry systems in Ghana, where increasing human population pressure and levels of land degradation are aggravating scarcity of arable land. Cocoa agroforestry has emerged as a promising landuse option to overcome the problem of land degradation and food insecurity. The direct and indirect benefits derived from such interventions have shown the potential to ensure food sufficiency. Econometric analysis indicates that planting hybrid cocoa varieties, extension services, membership of farmers' association and training are key factors in the adoption of cocoa agroforestry among smallholders in Ghana. Medium-shade cocoa agroforestry systems are seen as a win-win solution that can support the restoration of deforested and degraded forest landscapes by focusing on intercropping cocoa plantations with 10 to 15 trees per hectare (four trees per acre). The study recommends that smallholder cocoa farmers should be encouraged towards these systems by connecting them with distributors of information and knowledge through the creation of networks, promoting the practice, and providing training programmes and relevant extension services. Cocoa agroforestry systems are seen as a sustainable practice that combines forestry and agriculture, making it one of the most promising strategies to increase food production without additional deforestation.
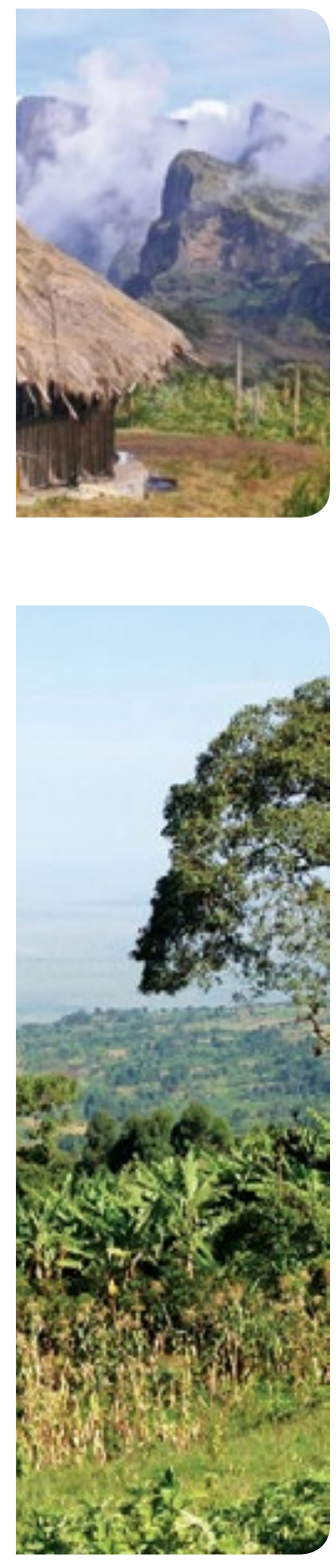


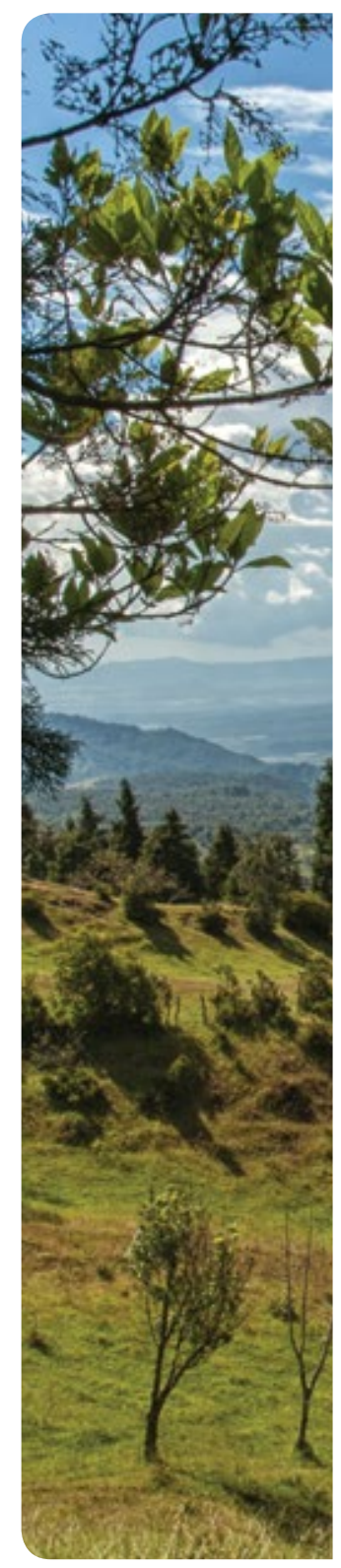

In Guatemala, it is estimated that $70 \%$ of the land is used for agricultural and forestry activities, including family farming and agribusiness. Guatemala is experiencing high levels of food insecurity and malnutrition as a result of irregularities in rainfall, recurrent natural disasters, environmental degradation, inadequate agricultural infrastructure and poor agricultural policies, among other factors. Family farmers depend on natural resources, but their practices are often the main cause of the degradation. Land and water are experiencing the highest rates of degradation and deterioration in Latin America. Most of these losses have been caused by fuelwood collection, unsustainable agricultural practices and land expansion for intensive agriculture use.

In 2000, in response to the high levels of hunger and malnutrition in the dry corridor, FAO, in coordination with the Ministry of Agriculture of Guatemala and local authorities, launched a special food security programme located in the province of Chiquimula. The scope of the project was to identify good practices in reducing food insecurity, with an emphasis on gender and ancestral knowledge, to create linkages between family farmers and national policies; and to establish an institutional framework aimed at combating hunger and malnutrition. The ancient and sustainable practice of planting dispersed trees of Gliricidia sepium within the plot of annual crops was used. The main objective of this practice was to provide protection to soil and crops from the erosive effect of rain and preserve soil moisture during the drought period, through the shade of the trees reducing evapotranspiration and the addition of organic matter through the leaves of the trees that naturally fall on the plot. The interaction of the local indigenous people and technical professionals from the programme created an alternative technology based on ancient knowledge, making use of multipurpose native trees from the dry forest. Based on analysis, this ancient agroforestry system, known as kuxur rum, has proven to be a good initiative in improving food and nutritional security, and is a practice with cultural relevance, revitalizing and perpetuating ancient and traditional ecological knowledge. It allows farmers to take advantage of local natural resources and decreases dependence on foreign inputs, resulting in an increase in yields and better soil moisture retention. Results also indicate that kuxur rum contributes to the four main dimensions of food and nutrition security: availability, by increasing crop productivity, principally of staple crops; access to food, by diversification of agricultural products and services; utilization, by reduction in water deterioration and unsafe food; and stability, by reducing the risk of crop failure. 
Mangroves contribute significantly to the economies of coastal communities and, as such, their maintenance is important for livelihoods and food security throughout the Pacific. From a food security and livelihoods perspective, mangroves support many types of fisheries - artisanal, commercial and recreational - and numerous types of fish, lobsters, crabs, molluscs and many other species. In Viet Nam, with about 169,000 hectares of mangroves along its 3,260-km coastline, mangroves are considered an important resource for socioeconomic development. Despite their importance, mangrove forests have declined significantly over recent decades, primarily through loss and degradation associated with population pressure, wood/firewood extraction and conversion to other land uses such as shrimp ponds, agricultural fields, salt pans, settlements, ports and coastal industrialization. This case study illustrates how restored mangrove ecosystems have enhanced the food security and livelihoods of poor coastal inhabitants by supporting fisheries, nurseries and habitats, as well as protecting coastal communities from natural disasters (such as typhoons and waves). Although the assessments in this research could not quantify all the values of mangroves in northern Viet Nam, this study indicates clear evidence that livelihoods have been enhanced through small-scale restored mangroves. In particular, the livelihoods of poor women have been enhanced and stabilized as a result of mangrove forest-based activities, such as collecting aquatic products and raising honeybees.

Community forestry, employed in many countries in Asia, involves people in communities working together to establish tree plantations or manage existing stands while simultaneously planting fruit trees and agricultural crops to satisfy food requirements and enhance livelihoods. In the Philippines, community forestry has been a major government strategy to promote sustainable development in the uplands for nearly four decades. This case study demonstrates that the key to successful FLR programmes lies in addressing the socioeconomic and food security issues of these community and smallholder farmers. The ecological reason for reforestation of denuded uplands is widely understood. However, when a reforestation programme does not provide short- and long-term financial benefits and is in conflict with smallholders' subsistence farming activities in terms of time, labour and use of the land, the programme is unlikely to succeed. The case study identifies and provides examples of financial return and food security as the prime motivators for communities to engage in watershed rehabilitation projects, conserve biodiversity and sustainably manage their forests.

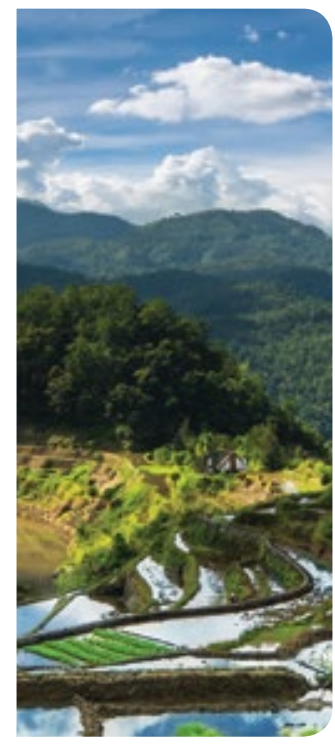


As part of the effort to fight climate change by reducing greenhouse gas emissions and stopping deforestation, we must consider that agricultural production - a key driver of forest clearance - will increase as the global population grows (Knoke, et al., 2012). However, agricultural practices can be sustainably managed through an integrative landscape approach that encompasses an FLR framework. As demonstrated in the Ghana, Brazil and Guatemala case studies, agroforestry systems that combine forestry and agriculture are instrumental in assuring food security and enhancing ecosystem resilience (Sanchez, 1999). Natural regeneration adopted at household level has shown the potential to increase yields and enhance food security during times of vulnerability in Burkina Faso. Case studies from Ethiopia, Viet Nam and Philippines illustrate the trade-offs between yield and environmental services; and adopt a multidisciplinary approach that goes beyond traditional practices and finds ways to directly improve the livelihoods of the millions of people who depend on forests and farming as their primary source of food and income.

\section{Why restore forest landscapes?}

The speed and intensity of disasters induced by climate change is outpacing the population's capacity to cope with food losses. As the climate warms, the adverse events will impact land quality and water availability. Land degradation leads to food insecurity, increased pests, biodiversity loss, reduced availability of clean water and increased vulnerability of affected areas and their populations to climate change and other environmental changes. Ecosystem resources are already stressed by overexploitation, pollution, habitat destruction, degradation and fragmentation. As estimated, about 1.5 billion people depend on degraded land (UNCCD, 2014); 1.6 billion people live in areas with water scarcity (World Bank, 2014); 2.6 billion people worldwide are dependent on wood fuel and charcoal for cooking and heating, mainly in developing countries (FAO, 2015); and about 795 million people are undernourished globally (FAO, IFAD, WFP, 2015). How can we address these existing challenges and feed 9 billion people by 2050 ?

FLR is an opportunity to safeguard our natural capital and support food and nutrition security. It promotes the sustainable use of natural resources, enhances the resilience of ecosystems, protects and restores the landscape - not only the forests, but also the agriculture, agroforestry, mangroves, and more, that sustain the lives of urban and rural communities. With nearly 2 billion hectares of degraded and deforested lands across the world that can potentially be restored through a wide range of FLR interventions, our legacy should not be measured by how much we did in the past, but by how much we leave for the future. 


\section{References}

FAO (2015). Soils are the Foundation for Vegetation which is cultivated or managed for feed, fibre, fuel and medicinal products. Rome, Italy: Food and Agriculture Organization.

FAO, IFAD, WFP (2015). The State of Food Insecurity in the World 2015. Meeting the 2015 international hunger targets: Taking stock of uneven progress. Rome, Italy: Food and Agriculture Organization.

GPFLR (2013). Assessing national potential for landscape restoration: A briefing note for decision makers. Brochure. Washington, DC, USA. Global Partnership on Forest Landscape Restoration (GPFLR).

IFPRI (2015). 2014-2015 Global Food Policy Report. Washington, DC: International Food Policy Research Institute.

Knoke, T., Román-Cuesta, R., Weber, M. and Haber, W. (2012). 'How can climate policy benefit from comprehensive land-use approaches?' Frontiers in Ecology and the Environment 10:438-445.

Maginnis, S. and Jackson, W. (2002). 'Restoring forest landscapes'. ITTO Tropical Forest Update 12(4):9-11.

Sanchez, P. (1999). 'Delivering on the Promise of Agroforestry'. Environment, Development and Sustainability 1(3):275-284

UN DESA, Population Division (2015). World Population Prospects: The 2015 Revision, Key Findings and Advance Tables. Working Paper No. ESA/P/WP.241. United Nations, Department of Economic and Social Affairs.

UNCCD (2014). Land Degradation Neutrality: Resilience at local, national and regional levels. Bonn, Germany: United Nations Convention to Combat Desertification.

World Bank (2014). Water and Climate Change. Available: http://water.worldbank.org/topics/water-resourcesmanagement/water-and-climate-change [accessed 30 November 2015]. 



\section{Contents}

Abbreviations

From degraded to functional restored forest land: Smallholder farmers curbing food insecurity in central Burkina Faso

Introduction

Forest context in Burkina Faso and rationale of the case study 23

Forest restoration interventions in central Burkina Faso 26

Methods 28

Analytical results and discussion $\quad 31$

$\begin{array}{ll}\text { Conclusion and implications } & 37\end{array}$

Cocoa agroforestry system as an alternative for degraded pastureland restoration, food security and livelihoods development among

smallholders in a Brazilian Amazon agricultural frontier 42

Introduction $\quad 45$

Challenges of forest landscape restoration $\quad 47$

Forest landscape restoration intervention: Innovative participatory approach 52

Results and analysis $\quad 57$

Lessons learned and recommendations 66

Agroforesty system kuxur rum enhancing food and nutritional security $\begin{array}{ll}\text { in Guatemala } & \mathbf{7 0}\end{array}$

$\begin{array}{ll}\text { Introduction } & 73\end{array}$

$\begin{array}{ll}\text { Forest landscapes and the dry corridor } & 76\end{array}$

Research questions and methods 89

Case study results 93

$\begin{array}{lr}\text { Conclusion and recommendations } & 101\end{array}$

Mangrove forest restoration in northern Viet Nam 106

$\begin{array}{lr}\text { Introduction } & 109\end{array}$

$\begin{array}{ll}\text { Methodology and data } & 112\end{array}$

$\begin{array}{ll}\text { The role of restored mangrove ecosystem in resilient food systems } & 114\end{array}$

Mangrove forests and livelihoods of coastal communities 115

$\begin{array}{ll}\text { Conclusion } & 119\end{array}$ 


\section{Restoring degraded forest landscape for food security:}

Evidence from cocoa agroforestry systems, Ghana 122

Introduction 125

Deforestation - a critical environmental issue 127

$\begin{array}{lr}\text { Objectives of the study } & 129\end{array}$

Justification of the study 130

$\begin{array}{ll}\text { Case study area } & 131\end{array}$

$\begin{array}{lr}\text { Conceptual and analytical framework } & 133\end{array}$

Results and discussion 134

$\begin{array}{ll}\text { Conclusion and recommendations } & 141\end{array}$

Economic contribution of communal land restoration to food security

in Ethiopia: Can institutionalization help? 144

$\begin{array}{ll}\text { Introduction } & 147\end{array}$

$\begin{array}{ll}\text { Background } & 148\end{array}$

$\begin{array}{lr}\text { Restoration interventions } & 149\end{array}$

Case study analysis 152

Results 156

$\begin{array}{ll}\text { Discussion } & 161\end{array}$

Conclusion and outlook 165

\section{Evidence-based best practice community-based forest restoration}

in Biliran: Integrating food security and livelihood improvements into watershed rehabilitation in the Philippines

$\begin{array}{ll}\text { Restoration context and research questions } & 179\end{array}$

Implications for improved community-based forest restoration projects 189

Progress and impact of the pilot watershed rehabilitation project 201

Key initial findings in implementing the pilot watershed rehabilitation project 208

Conclusion 213 


\section{Abbreviations}

\begin{tabular}{|c|c|}
\hline ACIAR & Australian Centre for International Agricultural Research \\
\hline ACTMANG & Action for Mangrove Reforestation, Japan \\
\hline AECID & Spanish Agency for International Development Cooperation \\
\hline AFS & agroforestry systems \\
\hline CAPPRU & Alternative Cooperative of the Small Rural and Urban Producers (Brazil) \\
\hline CAS & cocoa agroforestry systems \\
\hline CBD & Convention on Biological Diversity \\
\hline CBFMA & Community-Based Forest Management Agreement (the Philippines) \\
\hline CBFMP & Community-Based Forest Management Program (the Philippines) \\
\hline CDF & cumulative distributive function \\
\hline CELAC & United Nations Economic Commission for Latin America and the Caribbean \\
\hline CEPLAC & $\begin{array}{l}\text { Comissão Executiva de Planejamento da Lavoura Cacaueira (Executive CommissionFor } \\
\text { Cocoa Farm Planning), Brazil }\end{array}$ \\
\hline $\mathrm{ClF}$ & community investment fund \\
\hline CRP & Contract Reforestation Project (the Philippines) \\
\hline DENR & Department of Environment and Natural Resources (the Philippines) \\
\hline FFS & Farmer Field School (Guatemala) \\
\hline $\mathrm{FIPI}$ & Forest Inventory and Planning Institute (Viet Nam) \\
\hline FLR & forest landscape restoration \\
\hline GDP & gross domestic product \\
\hline GPFLR & Global Partnership on Forest and Landscape Restoration \\
\hline ITTA & International Institute of Tropical Agriculture \\
\hline KFAl & Kawayanon Farmers Association Incorporated (the Philippines) \\
\hline MARD & Ministry for Agriculture and Rural Development (Viet Nam) \\
\hline ML & maximum likelihood \\
\hline NGO & non-governmental organization \\
\hline NGP & National Greening Program (the Philippines) \\
\hline NORAD & Norwegian Agency for development and Cooperation \\
\hline NTFPs & non-timber forest products \\
\hline REDD & Reducing Emissions from Deforestation and Forest Degradation \\
\hline SEMAGRI & São Félix Municipal Bureau of Agriculture \\
\hline SFX & São Félix do Xingu (Brazil) \\
\hline STCP & Sustainable Tree Crop Program \\
\hline TNC & The Nature Conservancy \\
\hline UDP & Upland Development Program (the Philippines) \\
\hline UNFCCC & United Nations Framework Convention on Climate Change \\
\hline WFP & World Food Programme \\
\hline
\end{tabular}




\section{From degraded to functional restored forest land:}

Smallholder farmers curbing

food insecurity in central

\section{Burkina Faso}

Ida Nadia S. Djenontin, ${ }^{1}$ Houria Djoudi ${ }^{2}$ 


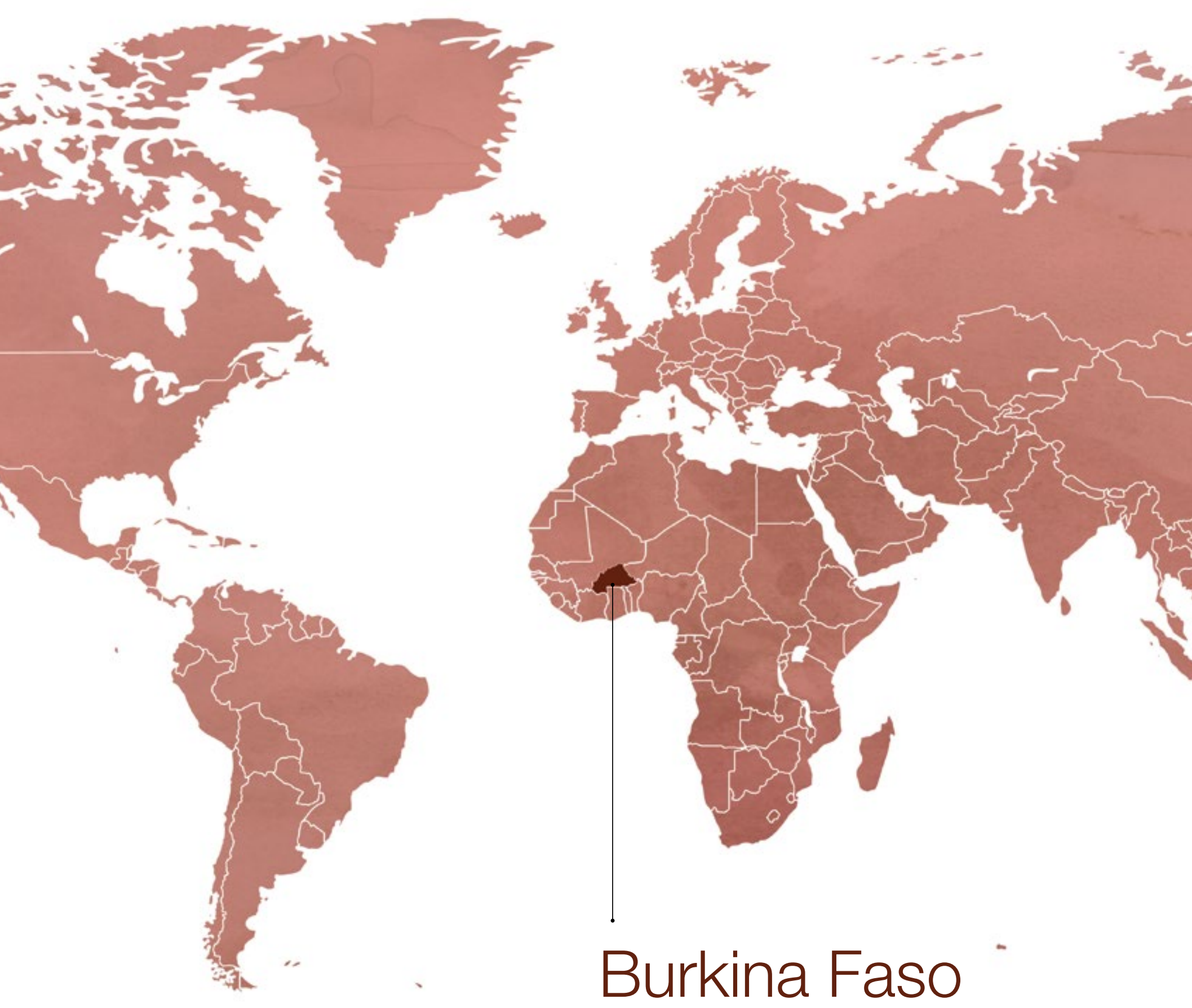

Country in West Africa

Size: cca 274,200 square kilometres in size

Population: 16.93 million (2013 World Bank)

Capital: Ouagadougou 


\section{Introduction}

Burkina Faso is a West African landlocked country of 15,234,000 inhabitants living on $274,000 \mathrm{~km}^{2}$ of land (INSD, 2006; FAO, 2011). Its urban population is $20.4 \%$ of the total (UNDP, 2011; World Bank, 2011). The country's economy depends predominantly on agriculture and livestock with $85 \%$ of the active workforce engaged in these sectors (CBD, 2010). Approximately $45 \%$ of the population lives below the poverty threshold of US\$1.25 a day (Human Development Index, 2013) and in rural areas, the poverty rate was estimated at $52.8 \%$ of the population in 2009 (World Bank, 2015).

Based on climate and phytogeography characteristics, the country is subdivided in two main zones: Sahelian and Sudanian, which is shown in Figure 1 (Ouédraogo, et al., 2010).

Along a north-south gradient (Nikiema, et al., 2001), the Sudanian vegetation includes savanna, dry or open forests, forests and gallery forests (MEDD, 2011) while the Sahelian vegetation is composed of scrublands dominated by acacia spp. and steppe shrubs

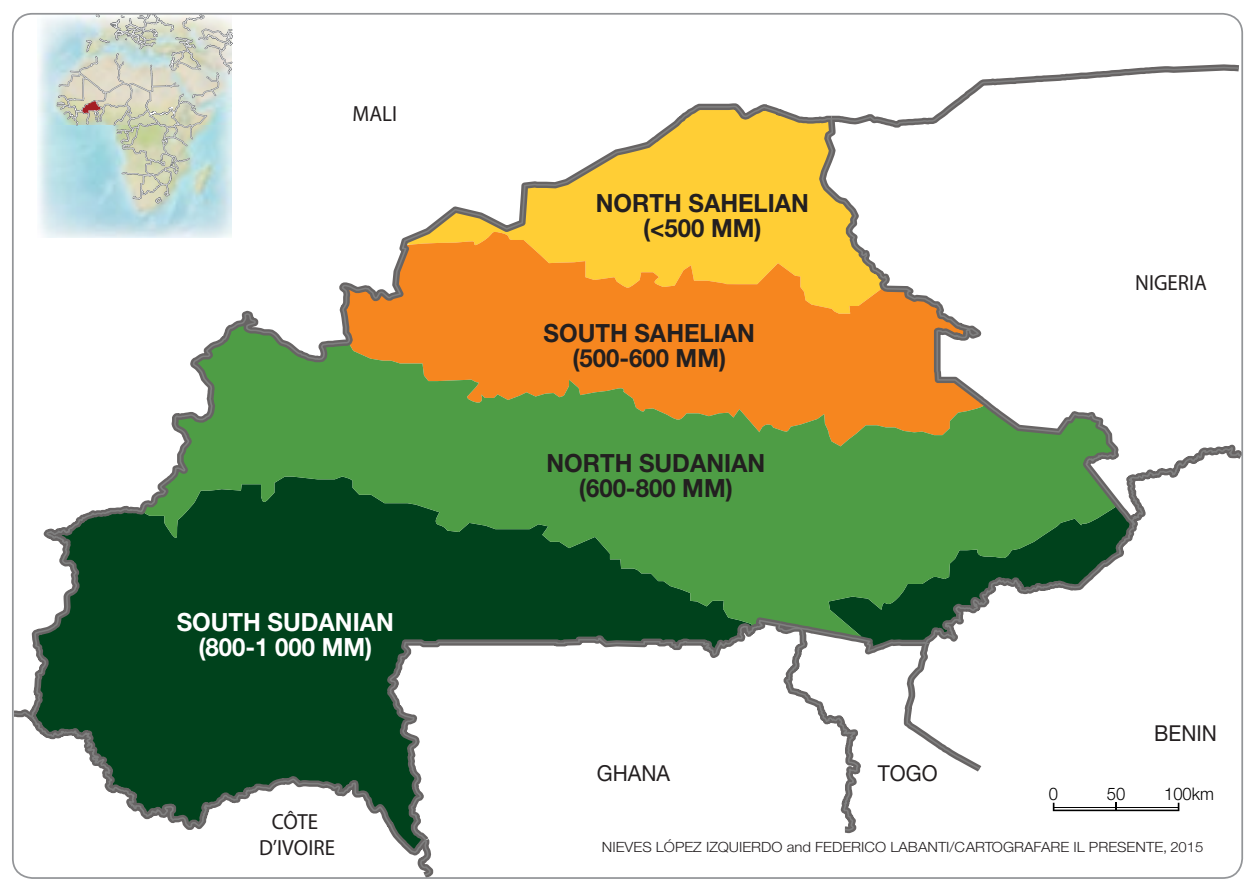

Figure 1.

Phyto-geographic and climatic zones of Burkina Faso 
with scattered trees. In line with the most widespread traditional land use system in West Africa (Boffa, 1999), the environment of this Sahelian country is a mosaic of savanna woodland, patches of forest, pasture and farmland, which provides goods and services to meet livelihood needs. Specifically, the most important categories of vegetation cover are savanna, wooded grassland, fallow and agroforestry parkland dominated by Vitellaria paradoxa, Parkia biglobosa, Tamarindus indica and Adansonia digitata (MEDD, 2011).

Natural resources constitute the main source of employment and revenue in Burkina Faso (Belem, et al., 2011), and, for its energy supply, the population is highly dependent on woody vegetation. (Ouédraogo \& Ferrari, 2012; Ouédraogo, et al., 2013). Though the country does not have substantial forest resources (Blin, et al., 2007), biomass contributes $85 \%$ of its energy consumption of which fuelwood and charcoal represent $97 \%$ (MEDDREEB III, 2011; Ouédraogo, 2011). Non-timber forest products (NTFPs) are important to many rural people (Hill, et al., 2007; Ouédraogo \& Ferrari, 2012; Ouédraogo, et al., 2013). These products augment revenue from livestock and agricultural resources, and contribute to food security, medicine and cultural value systems (FAO, 2010). Shea nuts (Vitellaria paradoxa), néré (Parkia biglobosa) and baobab (Adansonia digitata) leaves are key supplements to the diets and income of rural households, with studies showing that NTFPs represent 16-27\% of women's income in Burkina Faso, which is mostly used to purchase food in seasons of resource scarcity (Lamien \& Vognan, 2001). In 2008, shea (Vitellaria paradoxa) production contributed CFA franc 15.5 billion to the national economy of which 0.5 billion was tax revenues and 13.5 billion foreign exchange earnings (MECVIPE, 2010). In addition, during extreme climatic (and non-climatic) events, and especially for the poorest households, forests and tree resources play an important role in coping with food scarcity (Djoudi, et al., 2013). 


\section{Forest context in Burkina Faso and rationale of the case study}

In jurisdictional terms, forests are divided into classified areas (25\%) and protected areas (75\%) (Kambire, et al., 2015). Rights over forest resources are tightly linked to rights over land in Burkina Faso. Forest governance cannot be addressed effectively without looking at land tenure, which is governed by law 014/96/ADP of 1996 about agrarian and tenure reform. This law implies that all land belongs to the state (Thieba, 2009) and therefore all forests (classified and protected) belong to the state. In both classified and protected areas, strictly legal restrictions apply, where local people's use rights over the natural resources only include subsistence extraction of dead wood, as well as of fruits and plants for food or medicinal uses (Pouliot, et al., 2012). All forms of marketing are excluded. Agriculture and grazing are authorized in addition to the usufruct rights in the protected domain according to the forestry code (law 006/97/ADP of 1997).

Despite the legal and regulatory frameworks for land and forest management at national scale, the forests and trees are often managed at the local level under customary agreements (USAID, 2010; CRS, 2014). Trees and tree ownership are strong indicators of land ownership (Brockhaus, et al., 2012). Customary tenure determines the rights of access to resources. This trend has been recently consolidated in law 034-2009/AN of 2009 on rural land tenure which enables a legal recognition of rights legitimated by customary norms and rules (USAID, 2010): individual and collective land rights; the transfer of certificates of rural land ownership through inheritance; oral and written rural land leases are formally recognized. Local land management institutions have also been created including a rural land service, village land commissions and local consultative bodies for land-related matters in rural municipalities. The law seeks to protect property rights, prevent and manage land conflicts, and build a framework for ensuring rural land tenure security.

The Global Forest Resources Assessment programme of FAO estimated a total forest area of 5,649,000 hectares in Burkina Faso, which represents $21 \%$ of the national territory (FAO, 2010) while national statistics reported 13,305,238 hectares in 2002 representing $48.52 \%$ of the national territory (MECV, 2009). These forest resources are unevenly distributed across the country, which is due to differences in rainfall and population density. The north and central regions are exposed to drought and desertification and thus, are less 
covered. The southern regions fall in the South Sudanian climatic zone and offer better conditions for forest and trees development (Ouédraogo, et al., 2010). One characteristic of Burkina Faso's environment is the rapid pace of forest degradation (Kambire, et al., 2015). The annual rate of forest loss in dry ecosystems in Africa was $0.2 \%$ in 2000 (Bodart, et al., 2013) and the annual deforestation rate for Burkina Faso is estimated to range from 0.91 to $1.03 \%$ (Fischer, et al., 2011; Pouliot, et al., 2012) because of over-exploitation and unsustainable land management (Ouédraogo, et al., 2010). Loss of forest cover in Burkina Faso between 1990 and 2010 was an average of 59,900 hectares or $0.87 \%$ per year (FAO, 2010). In total, between 1990 and 2010, Burkina Faso lost $17.5 \%$ of its forest cover $(1,198,000$ hectares), with the parkland systems degrading fastest (Wardell, et al., 2003; Ouédraogo, et al., 2011).

The drivers of land degradation and deforestation are associated mainly with expansion of agriculture by using extensive techniques and other harmful practices (cash crops requiring large areas, agro-business, bush fires) that result in converting forest and woodland into cropland. Paré, et al., (2008) and Ouédraogo (2006a) reported that between the early 1980 s and early 2000 s, cropland increased at an annual rate of $1 \%$. Other factors contributing to land degradation and deforestation include the high demand for wood fuel and charcoal, overgrazing, bush fires, mining activities (Kambire, et al., 2015), population growth and migration from the Central Plateau to areas with higher rainfall and better soils (Ouédraogo, et al., 2009).

Climate change - unpredictable rainfall patterns and extreme weather events - is becoming a threat to agriculture in the Sahel and in Burkina Faso where rainfall is highly variable (Zorom, et al., 2013; Christensen, et al., 2007). In some years this has dramatic impacts on forest ecosystems and food security (Gonzalez, 2001; Schozle, et al., 2006). Thus, food security and livelihood strategies of smallholder farmers are threatened by the magnitude of the effects of climate variability (Sendzimir, et al., 2011) and also by the depletion of forests. However, while advocating for environmental sustainability, there is a constant and intensified emphasis by developers and donors on achieving food security (Maxwell, et al., 2013).

In the Sahel, after the devastating droughts and famines that occurred in the 1970 s and 1980s, re-greening to rebuild resilience has been the focus of scientists, development agencies, government and non-governmental organizations (NGOs) (West, et al., 2008; Sendzimir, et al., 2011). Reforestation has been extensively promoted and adopted to restore or enhance the provision of ecosystem goods and services (Chidumayo \& Gumbo, 2010; Jindal, et al., 2008) to meet food security and livelihood needs. Government, donors and NGOs have supported land restoration activities by farmers and communities (Olsson, 
et al., 2005; Reij, 2006; Sendzimir, et al., 2011; Sop \& Oldeland, 2013). However, to achieve the Bonn Challenge of September 2011 which calls for the restoration of 150 million hectares of deforested and degraded lands by 2020 (including the commitments of the Convention on Biological Diversity (CBD) Aichi Target 15, the UNFCCC REDD+ goal and the Rio+20 land degradation target), a significant and effective increase in efforts is still required in the forest landscape restoration interventions in the Sahel. Land restoration and ecosystem rehabilitation interventions in northwestern Burkina Faso have been documented (Sawadogo, 2011). Going beyond that, this research contributes to show how land restoration intervention can specifically enhance food security needs in order to further advocate its integration into policy and practice. This case study in central Burkina Faso emphasizes the potential of forest landscape restoration interventions to mitigate food insecurity of smallholder farmers by providing an understanding of its role and capacity in terms of enhancing land productivity, provision and regulation services that contribute to food security especially during the lean season. 


\section{Forest restoration interventions in central Burkina Faso}

In 2001, a group of forest restoration experts who met in Segovia, Spain defined forest landscape restoration as: 'a planned process that aims to regain ecological integrity and enhance human well-being in deforested or degraded landscapes' (Mansourian, et al., 2005; ITTO \& IUCN, 2005). The concept has evolved to accommodate new perspectives and ideas on what it entails and what sets it apart from other more conventional approaches to putting trees back into the landscape (Mansourian, et al., 2005). Likewise, in Burkina Faso, restored forest lands are defined as 'fallow protected against any forms of pressure from human activities - such as grazing, wildfire, logging - to allow vegetal cover regeneration with enhanced primary production and modification the structure of the vegetation' (Sawadogo, 2011). The restoration actions that are ongoing in Burkina Faso illustrate the country's engagement toward securing its environment. The initiative of restoring forest lands in the early 2000s led by NewTree/Tiipaalga NGO ${ }^{1}$ involved the areas where forest resources were already very rare particularly in the central and northern parts of the country. Indeed, the general consensus among researchers and policy makers is that the environment of the central region in Burkina Faso continues to degrade (Reij, et al., 2005) although significant results in terms of scale and impacts have been achieved by investments in soil and water conservation in these regions (Reij, et al., 2009). These investments have led to restoring the productivity of degraded land for agriculture and have generated new agroforestry parklands as a co-benefit.

The land restoration activities developed by Tiipaalga involve assisted natural regeneration of tree resources to increase availability of forest and agricultural products, as well as increasing biodiversity. This is in line with IUCN's view which states that forest land restoration is a stakeholder engagement process to restore the function and productivity of degraded forest land - through a variety of place-based interventions, including tree planting, managed natural regeneration or improved land management.

At household level, about 3 hectares of degraded land (mostly land that used to be cultivated) is enclosed to allow the natural regeneration of woody and herbaceous

1 An Ouagadougou-based association, which started formally in 2006 but operated in Burkina Faso from 2003 under the name NewTree. 


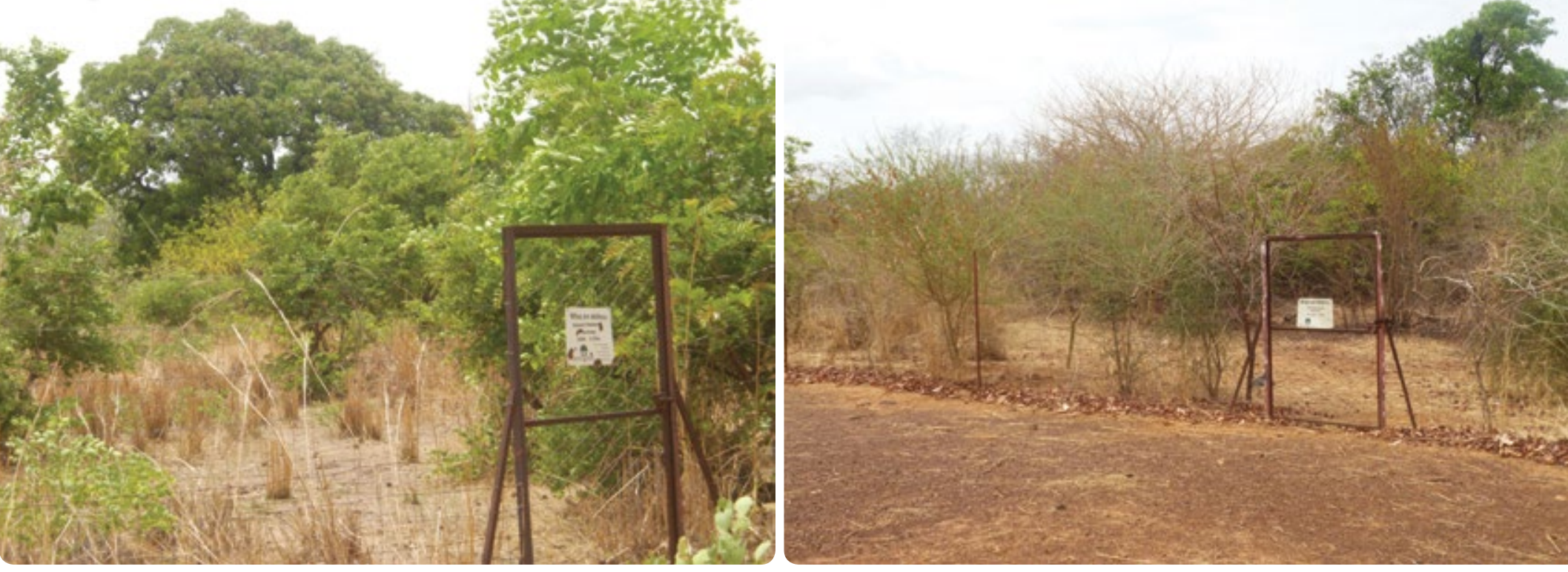

vegetation. The area is fenced to protect it against livestock pressure, and a 10-m strip around the perimeter, which is equal to 0.8 hectares, is cultivated to serve as a firebreak (Figure 2). To stick with IUCN's view, the current restoration activities are more than just planting trees - they are about restoring land productivity, forest resources and ecosystem functions 'forward' to meet present and future needs and provide multiple benefits and accommodate multiple uses over time. Both men and women of the household are engaged in the activities of the reforested area. By December 2014, 247 such enclosures in 109 villages in 8 provinces in Burkina Faso has been recorded, accounting for a total of 722 hectares of reforested lands under Tiipaalga's leadership.

A provisional administrative document is attributed to the lands to confirm their tenure. This document proves the households' rights over the land and stands as a crucial step towards acquiring legal tenure certificates according to the land reform in Burkina Faso. The objective of restored forest lands was firstly to restore not only the vegetation cover in order to assure the provision of ecosystem services for communities in affected areas, but also to create potential carbon storage in a climate change mitigation strategy. As such, this initiative is emerging as a promising opportunity to enhance the resilience of smallholders' livelihoods.
Figure 2.

Land restoration at household level in the central Burkina Faso (photo credit: Ida Nadia Djenontin) 


\section{Methods}

\section{Analytical framework}

Food security exists when all people, at all times, have physical and economic access to sufficient, safe and nutritious food that meets their dietary needs and food preferences for an active and healthy life (Bickel, et al., 2000). Indicators to assess food security are primarily based on four main pillars of food security defined by FAO, and reported by Barrett (2010): food availability, food access, food utilization and food stability or vulnerability.

In this paper, the analysis at a household level is mainly linked to the first two pillars of food security: food availability and food access. To envision the role and importance of restored forest lands for enhancing food security, we first looked at the diversity of products from the reforested lands, the share of the different products in the total produce, their usage purposes and their perceived importance to contributing to food security. Secondly, we examined the role of the reforested lands as a safety net during the lean seasons. We assessed whether harvesting and consumption periods of products from the restored lands is linked to the periods of food deficit recorded among smallholder households. Furthermore, we analysed, based on smallholders' perceptions, the potentialities of those restored areas to provide regulation services such as slowing down erosion, improvement of soil fertility and biodiversity. Figure 3 presents how the measured parameters of restoration of forest lands in assessing food security connect with food security pillars and their indicators.

\section{Study area and data}

The restored forest lands in this case study are located across three provinces of central Burkina Faso: Kadiogo, Kourweogo and Oubritenga (Figure 4). These provinces straddle the South Sahelian and the North Soudanian zones and register about 700-800 $\mathrm{mm}$ rainfall annually. The vegetation in these provinces consists of shrubs and small trees, agroforestry parklands and, occasionally, small dense thicket. There is an average annual temperature ranges of $30^{\circ} \mathrm{C}$ with a seasonal amplitude of $10^{\circ} \mathrm{C}$. The area benefits from many development interventions as it is one of the poorest zones in the country (Reij, et al., 2005).

In the framework of a global forest and climate change adaptation project in the West Africa Sahel, primary data on different land uses were collected, from May to July 2014, 


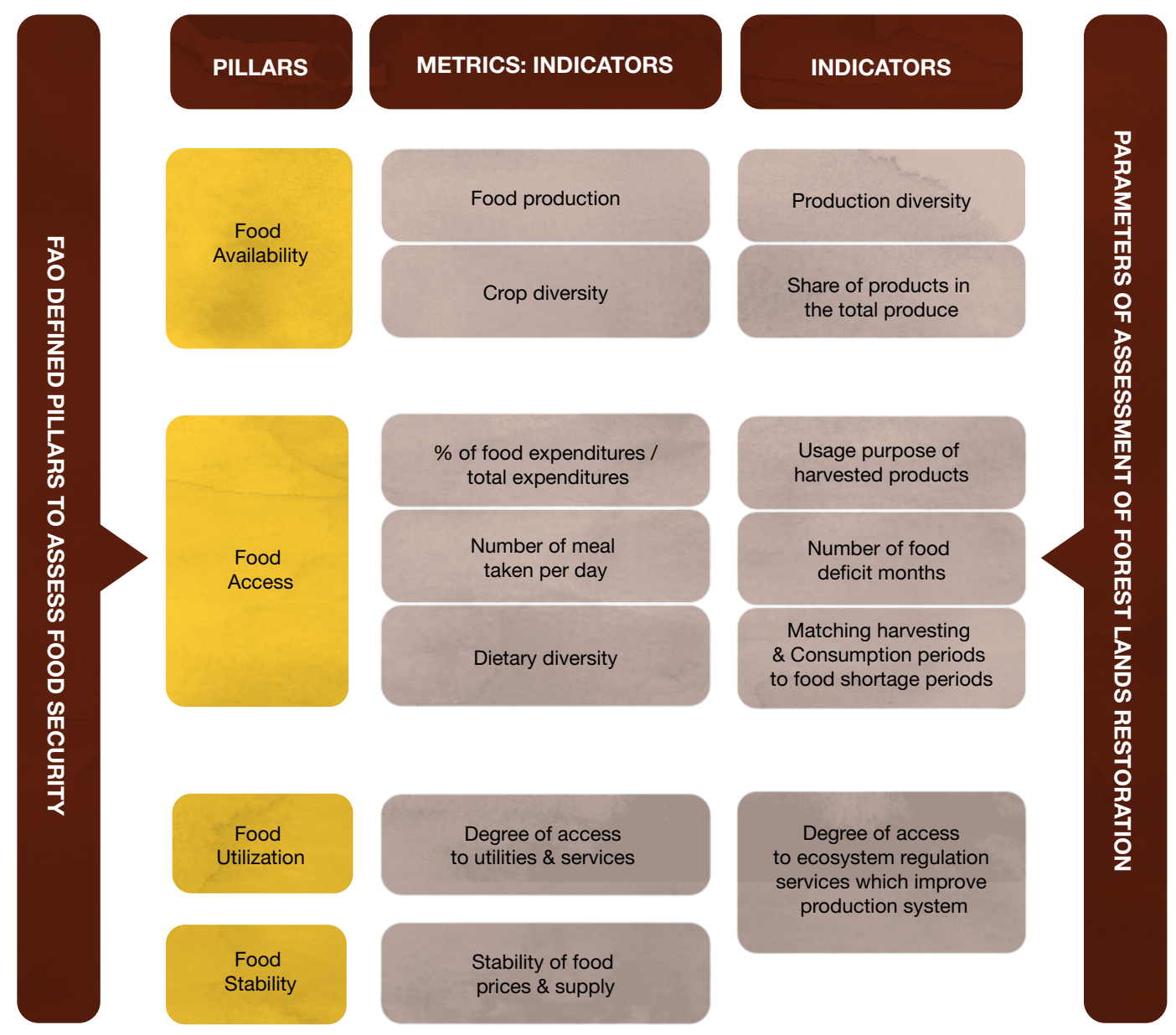

using a structured questionnaire at household level. A stratified random selection of 38 key informant households among the beneficiaries of land restoration interventions by Tiipaalga in the above-mentioned provinces was used for interviews. The collected data, both Figure 3. Integrated analytical framework of the study quantitative and qualitative, include household socioeconomic characteristics, livelihood assets, food security aspects, production from the restored areas, food deficit months, as well as perceptions of land restoration interventions contributing to food security and improving regulation services (soil fertility, erosion reduction, etc.). Project coordinators and members were also interviewed when necessary. Data were entered in a CSPro input mask and analysed with Stata 12.1 and Excel software in line with the objective of the paper. 
Figure 4.

Case study sites in central Burkina Faso

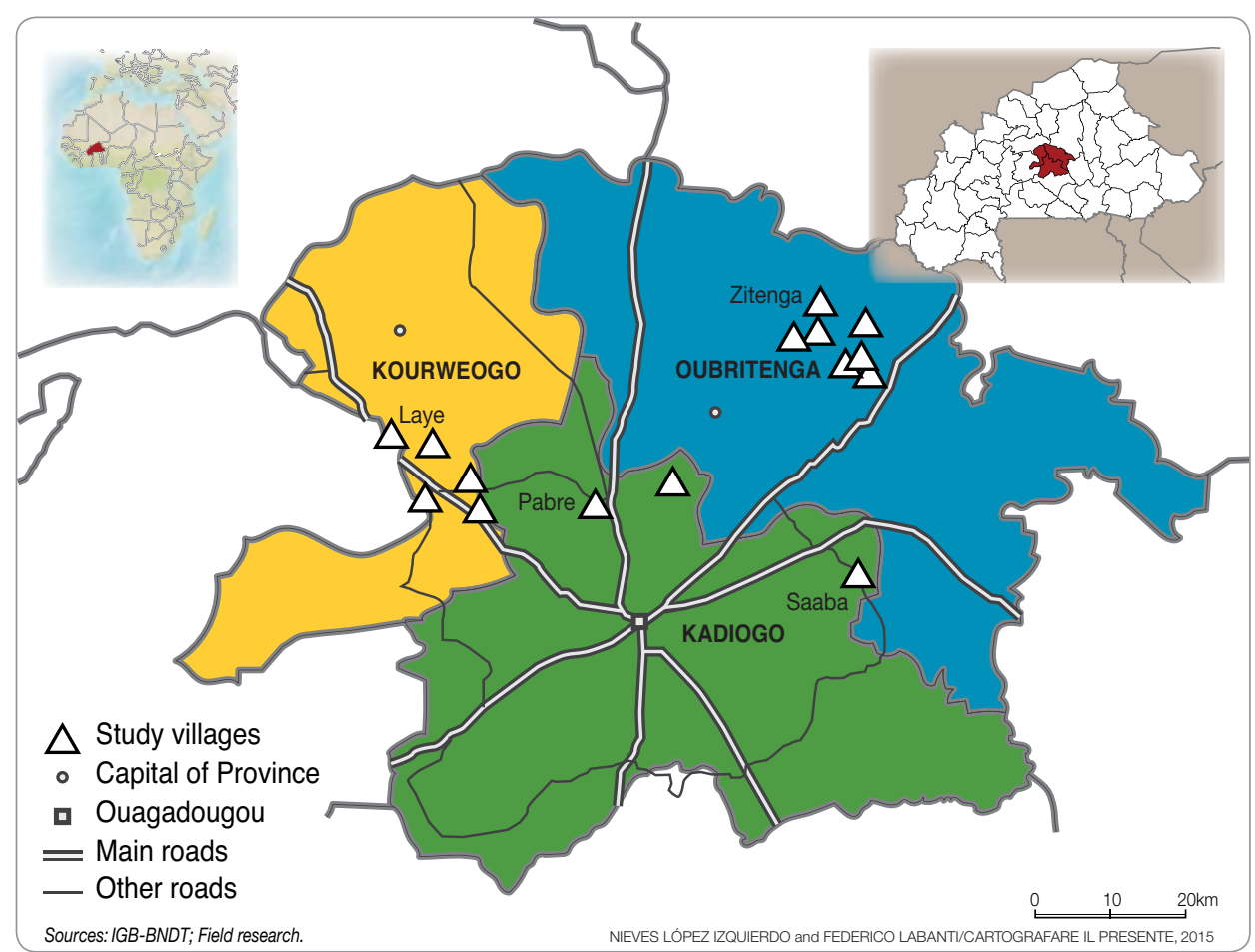




\section{Analytical results and discussion}

\section{Products diversity and their share in total production}

The different products harvested from the restored area are categorized into six product types including NTFPs used for food, cereals, legumes, non-edible forest products, fodder for livestock and other products. The share of total production by category: is food NTFPs (26.58\%), legumes (23.63\%), non-edible forest products (18.57\%) and fodder for livestock (17.30\%). Cereals and other products account, respectively, $7.17 \%$ and $6.75 \%$. This is confirmed by the specific products harvested by households who implement forest lands restoration strategies. Results indicate that, on average, about $6( \pm 2)$ different products are harvested by households (Figure 5).

Agricultural products

(Cereals \& legumes crops)

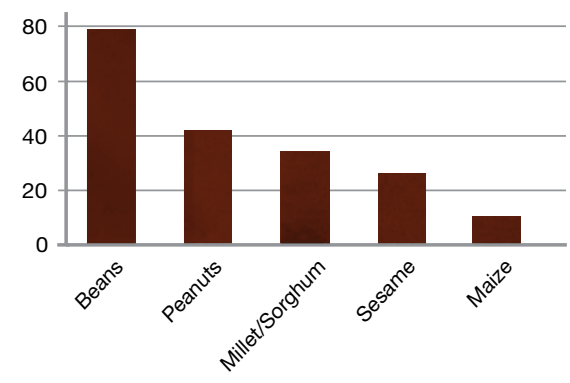

Non-food Forest Products

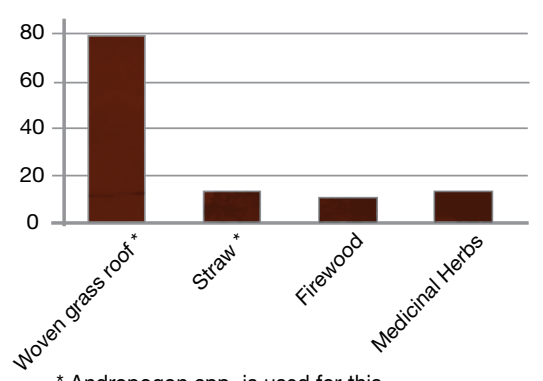

Food NTFPs

(Fruits, or Nuts, or Leaves of species)

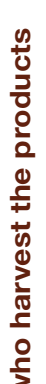

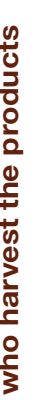

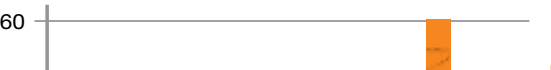

0

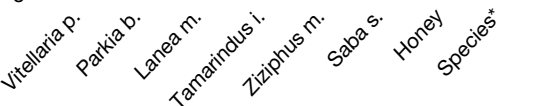

* Leaves of Moringa o.; Bombax c.; Adansonia d.

\section{Fodder for livestock \& other products} (wildlife)

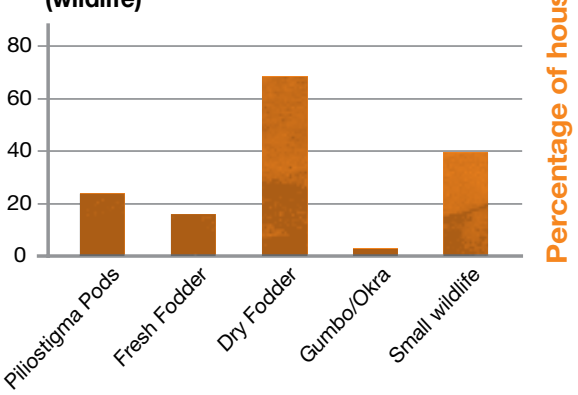

Figure 5.

Different products and product types harvested from restored lands 
The major products harvested are beans, peanuts, Andropogon spp. used for weaving grass roofs, honey, dry fodder, nuts of Vitellaria paradoxa, and small wildlife, birds and rodents (squirrels, partridges, rats, hedgehogs, hares and foxes). Among the food NTFPs, Vitellaria paradoxa nuts and Parkia biglobosa fruit are considered major NTFPs in Burkina Faso (Teklehaimanot, 2004; Coulibaly- Lingani, et al., 2009), but the other NTFPs are also important (Chidumayo \& Gumbo, 2010).

\section{Use of harvested products}

The harvested products are used differently at household level and the usages include either own- consumption by the households or commercialization or both. The share of home consumption and commercialization of products reveals that cereals are entirely and exclusively used for household food consumption. For instance, maize and millet/ sorghum harvested, from the 10-m strip round the perimeter serving as firebreak, are used for household consumption only. Also legumes and small rodents are mainly used for household consumption. Beans and peanuts are harvested for consumption while sesame is marketed. Honey and nuts of the shea tree (Vitellaria paradoxa) are commercialized whereas the other food NTFPs are consumed by household members. The trends in the use of the harvested forest products confirm the findings of related studies on household use of forest products (Hill, et al., 2007; Ouédraogo \& Ferrari, 2012; Ouédraogo, et al., 2013). The results indicate that the products from the restored forest lands are primarily used for household level needs and to overcome food scarcity rather than for purposes of income generation.

\section{Perceived food security impacts of restored forest lands}

On average, the lands were under restoration for $4.8( \pm 1.4)$ years. When asked, both men (household head) and women (household wives) assessed the contribution of the restored forest land to meeting food availability: $66 \%$ of the interviewed households attributed a high importance with a ranking scale from 0 to 3 ('no' to 'high' importance). The restored forest land is given a medium importance by $13 \%$ of the households and a low importance by $21 \%$ of the households. These statistics imply that most of the households perceived a relatively high importance of their restored forest land to contributing to meet food availability. The low importance recorded comes from households whose reforested lands are still new (two to three years old). In addition, as described in Table 1, four out of the six types of harvested products from the reforested lands are ranked as relatively high by households. 


\section{Product types}

Importance for food security ${ }^{a}$

Cereals (millet/sorghum, maize)

2.87

Legumes (beans, peanut, sesame)

2.69

Food NTFPs (honey, nuts of Vitellaria paradoxa, fruits of Parkia biglobosa, Tamarindus indica, Saba senegalensis, Zizyphus mauritiana, and Lannea microcarpa, leaves of Bombax costatum, Moringa oleifera and Adansonia digitata used for sauces and medicines)

Non-food NTFPs (firewood, Andropogon spp. used for straw) and woven grass roof; medicinal herbs)

Fodder for livestock (fresh fodder, dry fodder, pods of Piliostigma spp. Piliostigma spp.)

Other products: gumbo/okra small wildlife (squirrels, partridges, rats, hedgehogs, hares, foxes)

Notes: a: No importance = 0; low importance = 1; medium importance $=2$; high importance $=3$.

\section{Restored lands as safety net}

The results from case study analysis indicate that the average number of food deficit months among the households is around $3( \pm 1)$. More precisely, Figure 6 below shows that the food deficit occurs mostly in the months of May, June, July and August.

These results are in line with studies of Millogo-Rasolodimby (2001), Janin (2004; 2006) and Thiombiano, et al. (2012) who found that the lean season in Burkina Faso is variable but falls within the period between the beginning of the rainy season to the harvest (May to August).

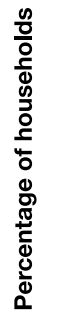

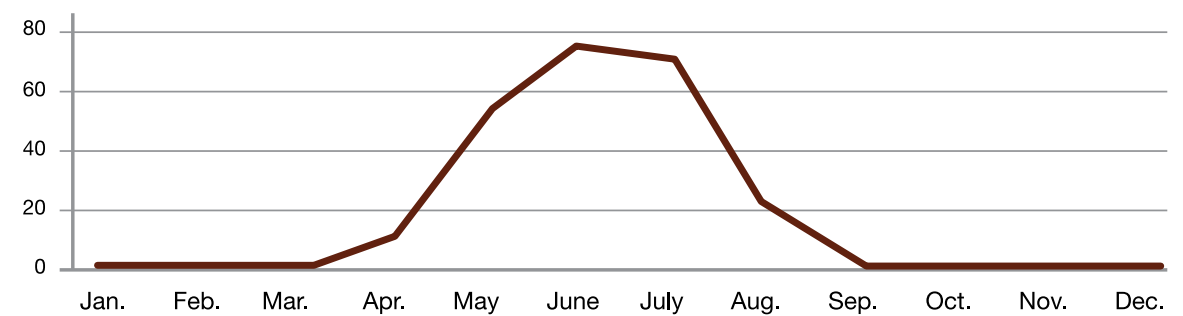

\begin{tabular}{|c|c|c|c|c|c|c|c|c|c|c|c|c|}
\cline { 2 - 10 } & Jan. & Feb. & Mar. & Apr. & May & June & July & Aug. & Sep. & Oct. & Nov. & Dec. \\
\hline $\begin{array}{c}\text { \% of HH } \\
(\mathbf{n}=38)\end{array}$ & 0 & 0 & 0 & 14.81 & 59.26 & 77.78 & 74.07 & 22.22 & 0 & 0 & 0 & 0 \\
\hline
\end{tabular}

Table 1.

Perceived importance of products, harvested from the restored lands, for food security
Figure 6.

Food deficit months and percentage of households experiencing food deficit 
Figure 7.

Yearly trend of harvesting of different product types in the restored forest lands

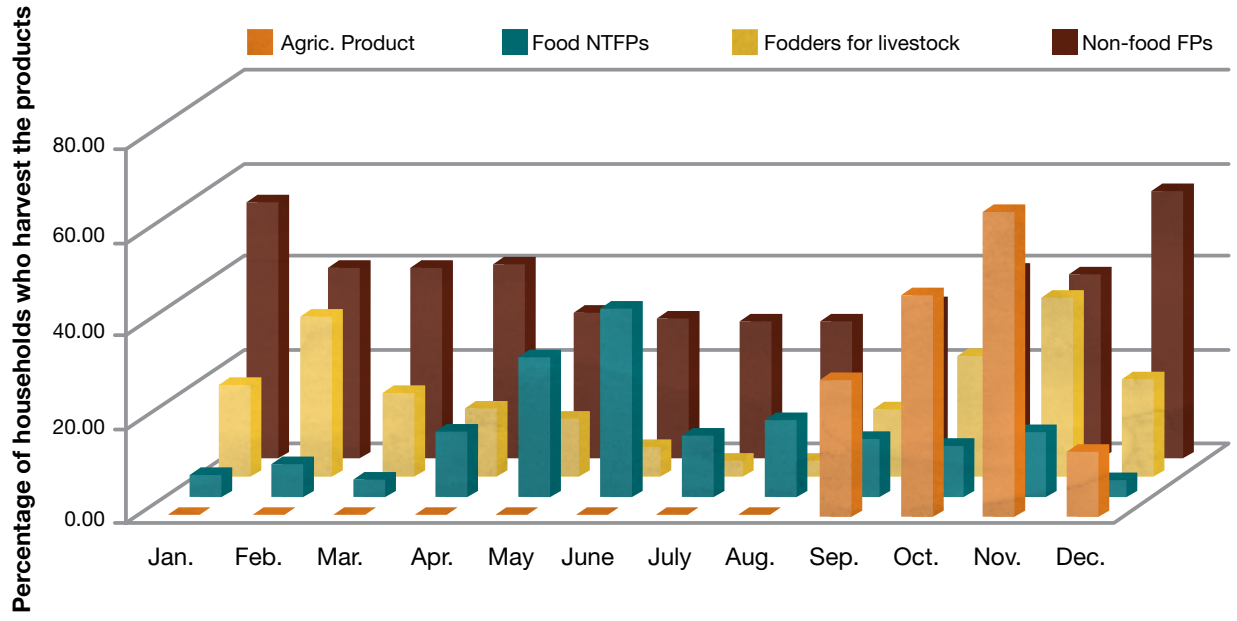

Regarding the harvesting periods of the products from the restored lands, results indicate that food NTFPs are harvested from April to November with May, June and August registering the greatest amount of harvesting among households (Figure 7).

The graph indicates that the lean season depicted among households( May to August) is covered by the progressive availability of food NTFPs. For instance, nuts of Vitellaria paradoxa and leaves of Bombax costatum, Moringa oleifera and Adansonia digitata, that are used for sauces, are harvested consistently from May to September. Fruits of Parkia biglobosa, Saba senegalensis, and Lannea microcarpa are harvested in May and June.

Such findings corroborate patterns observed and pointed out in related works done by Millogo-Rasolodimby (2001) and Thiombiano, et al. (2012). The species, their related harvesting period, as well as their consumption to overcome the period of food shortage are consistent with the studies mentioned above. Honey is harvested all year long, but mostly in April, May and September. Non-food NTFPs are also relatively available to households during the lean season with firewood as the main product.

In addition to their availability, the actual consumption occurs also in the same months of harvesting, especially for food NTFPs (Figure 8). This is not because they are quickly perishable, but it shows the obvious needs to overcome a food deficit. These features imply that the restored lands reflect a strategy and means of diversification of food sources to overcome food shortages. These results align with those of Little, et al. (2001) who stated that poor small farmers manage risks by diversification of food sources. Janin (2004) and 


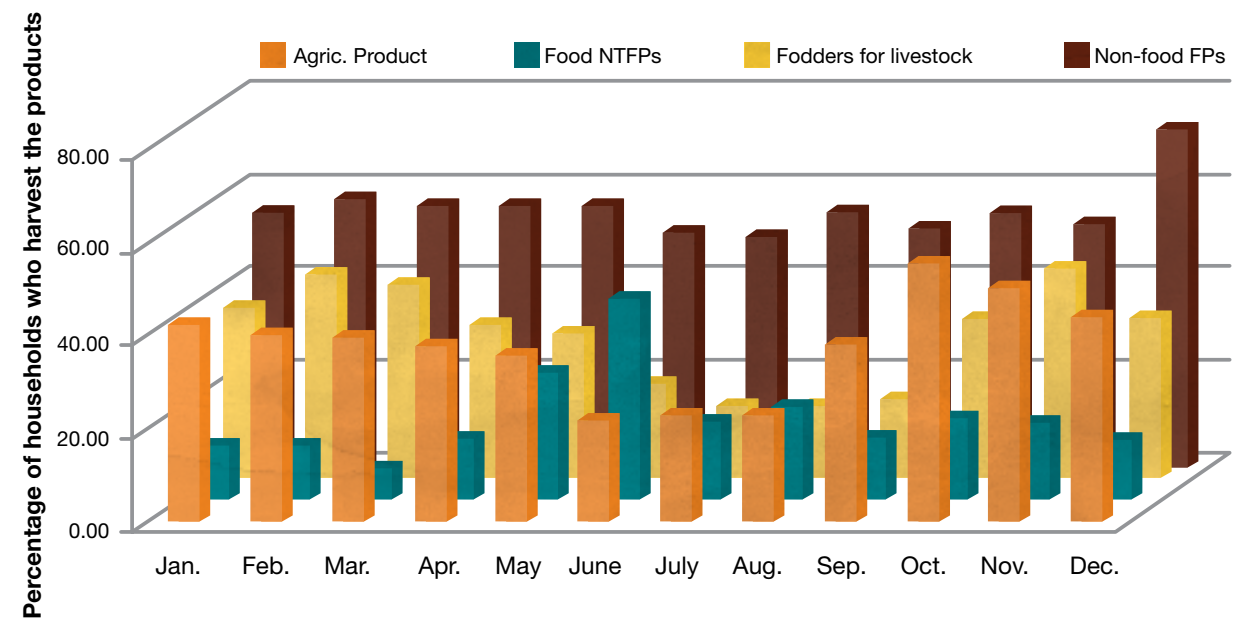

Ouédraogo (2006) reported three types of responses developed by the Sahelian farmers of Burkina Faso among which is the harvesting of wildlife products to acquire additional food commodities.

In contrast to a study of Wunder, et al. (2014), which fails to identify the importance of forest resources for seasonal gap-filling, we find here that the restored forest lands function as safety nets. Our findings align with those of Djoudi, et al. (2013) and also Kalinganire, et al. (2008) who argue that tree-based systems act as safety nets during months when grain is in short supply and during years of intense drought as they are sources of food including fruits, fats, oil, leafy vegetables, nuts and condiments that serve as complements to local staple food crops.

\section{Restored forest lands and regulation services}

The restored forest lands also contribute to providing ecosystem services which enhance production. Table 2 highlights the perceived role of the restored forest lands in terms of soil fertility regeneration, biodiversity and reduction of erosion. Results reveal that households perceive significant ecosystem services provided by the restored forest lands. Respectively 92\%, $81 \%$ and $79 \%$ of households perceive a strong improvement in soil fertility regeneration, biodiversity and erosion reduction in the restored areas.
Figure 8.

Yearly trend of consumption of different product types in the restored forest lands 
Table 2.

Household perception of ecosystem regulation services provided by the restored lands

\begin{tabular}{lll}
\hline Variables $(\mathbf{n}=\mathbf{3 8})$ & Parameters of assessment (\%) & Percentage of households \\
\cline { 2 - 3 } Soil fertility regeneration & Slightly & 0.00 \\
\cline { 2 - 3 } & Moderately & 2.60 \\
\cline { 2 - 3 } & Strongly & 5.30 \\
\hline Biodiversity regeneration & Not at all & 92.10 \\
\cline { 2 - 3 } & Slightly & 0.00 \\
\hline & Moderately & 5.30 \\
\hline & Strongly & 13.20 \\
\hline & Slightly & 81.60 \\
\hline & Moderately & 10.50 \\
\hline & Strongly & 10.50 \\
\hline
\end{tabular}

These patterns in household perception of regulation services confirm a study of Sawadogo (2011), which pointed out that restored lands are considered as a biological technique for conserving water and soil. Similarly, Kessler, et al. (1998) reported that the enclosure of a degraded pastoral zone in Bam province (Zanamogho) in Burkina Faso reduced the rate of bare soil by $19 \%$ through regeneration of herbaceous cover $(+137 \%)$ and wood (+19\%) between 1990 and 1994. 


\section{Conclusion and implications}

Environmental degradation that is exacerbated by climate change is threatening smallholders' food security in the Sahel. Forest land restoration is emerging as a promising opportunity to enhance the resilience of landscapes and livelihoods. This practice of reforesting lands goes beyond planting trees for ecological benefits, and also integrates the value of trees for livelihoods, as well as the diversity of trees to provide food in times of scarcity. This case study provides evidence that small-scale reforested lands offer an appropriate strategy and means of diversification of food sources to help curb food deficits in the months before the major harvest of food grains. However, the implementation of forest land restoration actions toward enhancing food security may be constrained at household level by some institutional processes mainly related to land tenure. Therefore, even with resource availability and the necessary will to engage in this practice, policies and legislation should develop enabling conditions to help households to invest in land restoration. Such research-based evidence is important to mainstream and strengthen adequate actions and should be used to inform policy dialogues on the importance of integrating restoration into land use plans to ensure food security of smallholders in the Sahel. More studies are also needed to understand the overall socio-environmental impacts at the landscape level. 


\section{References}

Barrett, C. (2010). 'Measuring Food Insecurity'. Science 327:825-828.

Belem, M., Bayala, J. and Kalinganire, A. (2011). 'Defining the poor by the rural communities of Burkina Faso: Implications for the development of sustainable parkland management'. Agroforestry Systems 83:287-302.

Bickel, G., Nord, M., Price, C., Hamilton, W. and Cook J. (2000). Guide to measuring food security, revised 2000. Alexandria VA, USA: US Department of Agriculture, Food and Nutrition Service.

Blin, J., Ficini, C., Faugere, G. and Dabat, M.H. (2007). Conférence internationale sur les enjeux et perspectives des biocarburants pour l'Afrique. Note de cadrage pour le Burkina Faso, p.41.

Bodart, C., Brink, A.B., Donnay, F., Lupi, A., Mayaux, P. and Achard, F. (2013). 'Continental estimates of forest cover and forest cover changes in the dry ecosystems of Africa between 1990 and 2000'. Journal of Biogeography 40(6):10361047.

Boffa, J.-M. (1999). 'Agroforestry Parklands in Sub-Saharan Africa'. FAO Conservation Guide 34, December 1999. Agroforestry Systems 52(2):169-170.

Brockhaus, M., Djoudi, H. and Kambire, H. (2012). 'Multi-level governance and adaptive capacity in West Africa'. International Journal of the Commons 6(2):200-232.

CBD (Convention sur la diversité biologique) 2010. Quatrième rapport national du Burkina Faso à la Conférence des Parties. Ouagadougou, p.119.

Chidumayo, E.N. and Gumbo, D.J. (2010). The Dry Forests and Woodlands of Africa: Managing for Products and Services, pp.288. London: Earthscan.

Christensen, J.H., Hewitson, B., Busuioc, A., Chen, A., Gao, X., Held, I., Jones, R., Kolli, R.K., Kwon, W.-T., Laprise, R., Magaña Rueda, V., Mearns, L., Menéndez, C.G., Räisänen, J., Rinke, A., Sarr, A. and Whetton, P. (2007). 'Regional climate projections'. In: Solomon, S., Qin, D., Manning, M., Chen, Z., Marquis, M., Averyt, K.B., Tignor, M. and Miller, H.L. (eds) Climate Change 2007: The Physical Science Basis. Contribution of Working Group I to the Fourth Assessment Report of the Intergovernmental Panel on Climate Change, pp.847-940. Cambridge, United Kingdom: Cambridge University Press.

Coulibaly-Lingani, P., Tigabu, M., Savadogo, P., Oden, P.-C. and Ouadba, J.M. (2009). 'Determinants of access to forest products in southern Burkina Faso'. Forest Policy and Economics 11:516-524.

CRS (Catholic Relief Service) (2014). Literature review of land tenure in Niger, Burkina Faso, and Mali: Context and opportunities. August 2014. Oliver Hughes, CRS Niger.

Djoudi, H., Brockhaus, M. and Locatelli B. (2013). 'Once there was a lake: Vulnerability to environmental changes in northern Mali'. Regional Environmental Change 13(3):493-508.

FAO (2011). State of the World's Forests 2011. Rome, Italy: Food and Agriculture Organization.

FAO (2010). Évaluation des ressources forestières mondiales 2010 : Rapport principal. Études FAO/Forêts, $n^{\circ} 163$; Rapport national Burkina Faso, FRA2010/032 : 70. Rome, Italy: Food and Agriculture Organization.

Fischer, C., Kleinn, C., Fehrmann, L., Fuchs, H. and Panferov, O. (2011). 'A national level forest resource assessment 
for Burkina Faso - A field based forest inventory in a semiarid environment combining small sample size with large observation plots'. Forest Ecology and Management 262:1532-1540.

Gonzalez, P. (2001). 'Desertification and a shift of forest species in the West African Sahel'. Climate Research 17:217-228.

Hill, T., Ouédraogo, Y. and Conditamde, L. (2007). 'L'entreprise villageoise d'exploitation des arbres au Burkina Faso : appuyer le développement des petites entreprises dont l'activité est fondée sur les produits forestiers non ligneux, in "La foresterie à petite échelle"'. Unasylva 228(58). Rome, Italy: Food and Agriculture Organization.

INSD (Institut national de la statistique et de la démographie, Burkina Faso) (2006). Rapport général sur le recensement de la population.

ITTO (International Tropical Timber Organization) and IUCN (The World Conservation Union) (2005). Restoring Forest Landscapes: An introduction to the art and science of forest landscape restoration. ITTO Technical Series No. 23, ISBN 4902045230.

Janin, P. (2004). 'La gestion spatio-temporelle de la soudure alimentaire dans le sahel burkinabe'. Revue Tiers-Monde 180:909-33.

Janin, P. (2006). 'La vulnérabilité alimentaire des Sahéliens : concepts, échelles et enseignements d'une recherche de terrain'. L'Espace Géographique 35:355-66.

Jindal, R., Swallow, B. and Kerr, J. (2008). Forestry-based carbon sequestration projects in Africa: Potential benefits and challenges. Natural Resource Forum 32(2):116-130.

Kalinganire, A., Weber, J.C., Uwamariya, A. and Kone, B. (2008). 'Improving rural livelihoods through domestication of indigenous fruit trees in parklands of the Sahel'. In: Akinnifesi, F.K., Leakey, R.B.B., Oluyede, C., Ajayi, O.C., Sileshi, G., Tchoundjeu, Z., Matakala, P. and Kwesiga, F.R. (eds) Indigenous fruit trees in the Tropics: Domestication, Utilization and Commercialization, pp.186-203. Wallingford, United Kingdom: CABI International Publishing.

Kambire, H.W., Djenontin, I.N.S., Kabore, A., Djoudi, H., Balinga, M.P.B., Zida, M. and Assembe-Mvondo, S. (2015). La REDD+ et l'adaptation aux changements climatiques au Burkina Faso: Causes, agents et institutions. Document occasionnel 123. Bogor, Indonesia: CIFOR (Center for International Forestry Research).

Kessler, J.J., Slingerland, M.A. and Savadogo, M. (1998). 'Regeneration of sylvo-pastoral lands in the Sahel zone under village management conditions'. Land Degradation and Development 9:95-106.

Lamien, N. and Vognan, G. 2001. Importance of non-wood forest products as source of rural women income in Western Burkina Faso. INERA Ouagadougou WP - INERA-4.

Little, P.D., Smith, K., Cellarius, B.A., Coppock, D.L. and Barrett, C.B. (2001). 'Avoiding disaster: Diversification and risk management among East African herders'. Development and Change 32(3):401-433.

Mansourian, S., Vallauri, D. and Dudley, N. (2005). Forest restoration in landscapes: Beyond planting trees. Springer Science \& Business Media

Maxwell, D., Coates, J. and Vaitla, B. (2013). How Do Different Indicators of Household Food Security Compare? Empirical Evidence from Tigray. Medford, USA: Feinstein International Center, Tufts University.

MEA (Millennium Ecosystem Assessment) (2005). Ecosystems and Human Well-being: Synthesis. Washington, DC: Island Press.

MECV (Ministère de l'Environnement et du Cadre de la Vie) (2009). Programme National de Gestion Durable des Ressources Forestières et Fauniques du Burkina Faso (2006-2015). Document provisoire, mai 2009. 
MECV-IPE (Ministère de l'Environnement et du Cadre de la Vie - Initiative Pauvreté Environnement) (2010). Évaluation Economique de l'Environnement et des Ressources Naturelles au Burkina Faso : Analyse économico-environnementale au niveau national (Phase 1). SBA, Ecosys Genève, CEDRES, PNUD, PNUE.

MEDD (Ministère de l'Environnement et du Développement Durable) (2011). Programme d'Investissement Forestier (PIFBurkina Faso) : Plan d'Investissement Forestier. Version finale.

MEDD-REEB III (Ministère de l'Environnement et du Développement Durable) (2011). Troisième Rapport sur l'état de l'environnement au Burkina Faso (REEB3).Version provisoire. Secrétariat Permanent du Conseil National pour l'Environnement et le Développement Durable.

Millogo-Rasolodimby, J. (2001). L'homme, le climat et les ressources alimentaires végétales en périodes de crises de subsistance au Burkina Faso au cours du 20e siècle. Thèse d'etat en biologie et écologie, Université de Ouagadougou (Burkina Faso).

Nikiema, A., Ouédraogo, S.J., Boussim, J. (2001). Situation des ressources génétiques forestières du Burkina Faso. Note thématique sur les ressources génétiques forestières.

Olsson, L., Eklundh, L. and Ardö, J.A. (2005). 'A recent greening of the Sahel - Trends, patterns and potential causes'. Journal of Arid Environment 63:556-566.

Ouédraogo, B. and Ferrari, S. (2012). Incidence of forest income in reducing poverty and inequalities: Evidence from forest dependent households in managed forest areas in Burkina Faso. Cahiers du GREThA, n²012-28.

Ouédraogo, F.C. (2006). La vulnérabilité alimentaire au Burkina Faso. Ouagadougou (Burkina Faso) : L'Harmattan.

Ouédraogo, I. (2006a). 'Land Use Dynamics in Bieha District, Sissili Province, southern Burkina Faso, West Africa'. UMOJA: Bulletin of the African and African American Studies Program 1(2):18-34.

Ouédraogo, I., Savadogo, P., Tigabu, M., Cole, R., Odén, P. C. and Ouadba, J.M. (2009). 'Is rural migration a threat to environmental sustainability in Southern Burkina Faso?' Land Degradation \& Development 20(2):217-230.

Ouédraogo, I., Tigabu, M., Savadogo, P., Compaoré, H, Odén, P.C. and Ouadba, J.M. (2010). 'Land cover change and its relation with population dynamics in Burkina Faso, West Africa'. Land Degradation \& Development 21(5):453-462.

Ouédraogo, I., Savadogo, P., Tigabu, M., Cole, R., Oden, P.C. and Ouadba, J.M. (2011). 'Trajectory Analysis of Forest Cover Change in the Tropical Dry Forest of Burkina Faso, West Africa'. Landscape Research 36(3):303-320.

Ouédraogo, K. (2011). L'étude prospective du secteur forestier en Afrique. Rome : FAO.

Ouédraogo, M., Ouédraogo, D., Thiombiano, T., Hien, M., Lykke, A.M. (2013). 'Dépendance économique aux produits forestiers non ligneux : Cas des ménages riverains des forêts de Boulon et de Koflandé, au Sud-Ouest du Burkina Faso'. Journal of Agriculture and Environment for International Development 107(1):45-72.

Paré, S., Söderberg, U., Sandewall, M. and Ouadba, J.M. (2008). 'Land use analysis from spatial and field data capture in southern Burkina Faso, West Africa'. Agriculture, Ecosystems \& Environment 127(3-4):277-285.

Pouliot, M., Treue, T., Obiri, B.D. and Ouédraogo, B. (2012). 'Deforestation and the Limited Contribution of Forests to Rural Livelihoods in West Africa: Evidence from Burkina Faso and Ghana'. Ambio 41(7):738-750.

Reij, C. (2006). More success stories in Africa's drylands than often assumed. Conference proceedings, Forum sur la Souveraineté Alimentaire, Niamey, 7-10 November 2006. Reseau des Organisations Paysannes et de Producteurs Agricoles de l'Afrigue de l'Ouest (ROPPA), Ouagadougou, Burkina Faso. 
Reij, C., Tappan, G. and Belemvire, C. (2005). 'Changing land management practices and vegetation on the Central Plateau of Burkina Faso (1968-2002)'. Journal of Arid Environments 63:642-659.

Reij, C., Tappan, G. and Smale M. (2009). Agro-environmental transformation in the Sahel: Another kind of "Green Revolution." Discussion paper. Washington, DC: International Food Policy Research Institute.

Sawadogo, H. (2011). 'Using soil and water conservation techniques to rehabilitate degraded lands in northwestern Burkina Faso'. International Journal of Sustainable Agriculture 9:120-128.

Scholze, M., Knorr, W., Arnell, N.W. and Prentice, I.C. (2006). 'A climate-change risk analysis for world ecosystems'. PNAS 103(35):3116-13120.

Sendzimir, J., Reij, C.P. and Magnuszewski, P. (2011). 'Rebuilding resilience in the Sahel: regreening in the Maradi and Zinder regions of Niger'. Ecology and Society 16(3):1.

Sop, T.K. and Oldeland, J. (2013). 'Local perceptions of woody vegetation dynamics in the context of a 'Greening Sahel': A case study from Burkina Faso'. Land Degradation \& Development 24:511-527.

Teklehaimanot, Z. (2004). 'Exploiting the potential of indigenous agroforestry trees: Parkia biglobosa and Vitellaria paradoxa in sub-Saharan Africa'. Agroforestry Systems 61:207-220.

Thieba, D. (2009). L'élaboration de la politique nationale de sécurisation foncière en milieu rural au Burkina Faso: Analyse de la participation et leçons. GRAF.

Thiombiano, D.N.E., Lamien, N., Dibong, D.S., Boussim, I.J. and Belem, B. (2012). 'Le rôle des especes ligneuses dans la gestion de la soudure alimentaire au Burkina Faso'. Sécheresse 23(2):86-93.

UNDP (United Nation Development Programme) (2011). Human Development Report 2011. New York, USA.

UNDP (United Nations Development Programme) (2013). Human Development Report 2013: The Rise of the South, Human Progress in a Diverse World. New York, USA.

USAID (2010). Burkina Faso: USAID Country Profile - Property Rights and Resource Governance.

Wardell, D.A., Reenberg, A. and Tøttrup, C. (2003). 'Historical footprints in contemporary land use systems: Forest cover changes in savannah woodlands in the sudano-sahelian zone'. Global Environmental Change 13(4):235-254.

West, C.T., Roncoli, C. and Ouattara, F. (2008). 'Local perceptions and regional climate trends on the Central plateau of Burkina Faso'. Land Degradation and Development 19(3):281-304.

World Bank (2011). World Development Indicators 2011.

World Bank (2015). Poverty headcount ratio at rural poverty line (\% of rural population). http://data.worldbank.org/ indicator/SI.POV.RUHC [accessed 15 September 2015].

Wunder, S., Borner, J., Shively, G. and Wyman, M. (2014). 'Safety Nets, Gap Filling and Forests: A Global-Comparative Perspective'. World Development 64:29-42. http://dx.doi.org/10.1016/j.worlddev.2014.03.005 [accessed 15 September 2015].

Zorom, M., Barbier, B., Mertz, O. and Servat, E. (2013). 'Diversification and adaptation strategies to climate variability: A farm typology for the Sahel'. Agricultural Systems 116:7-15. 


\section{Cocoa agroforestry system}

as an alternative for degraded pastureland restoration,

food security and livelihoods

development among

smallholders in a Brazilian

Amazon agricultural frontier

Carlos Valério Aguiar Gomes, ${ }^{1}$ Edenise Garcia, ${ }^{1}$

Erivaldo de Sousa Alves, ${ }^{1}$ Márcio Marques Queiroz ${ }^{1}$ 


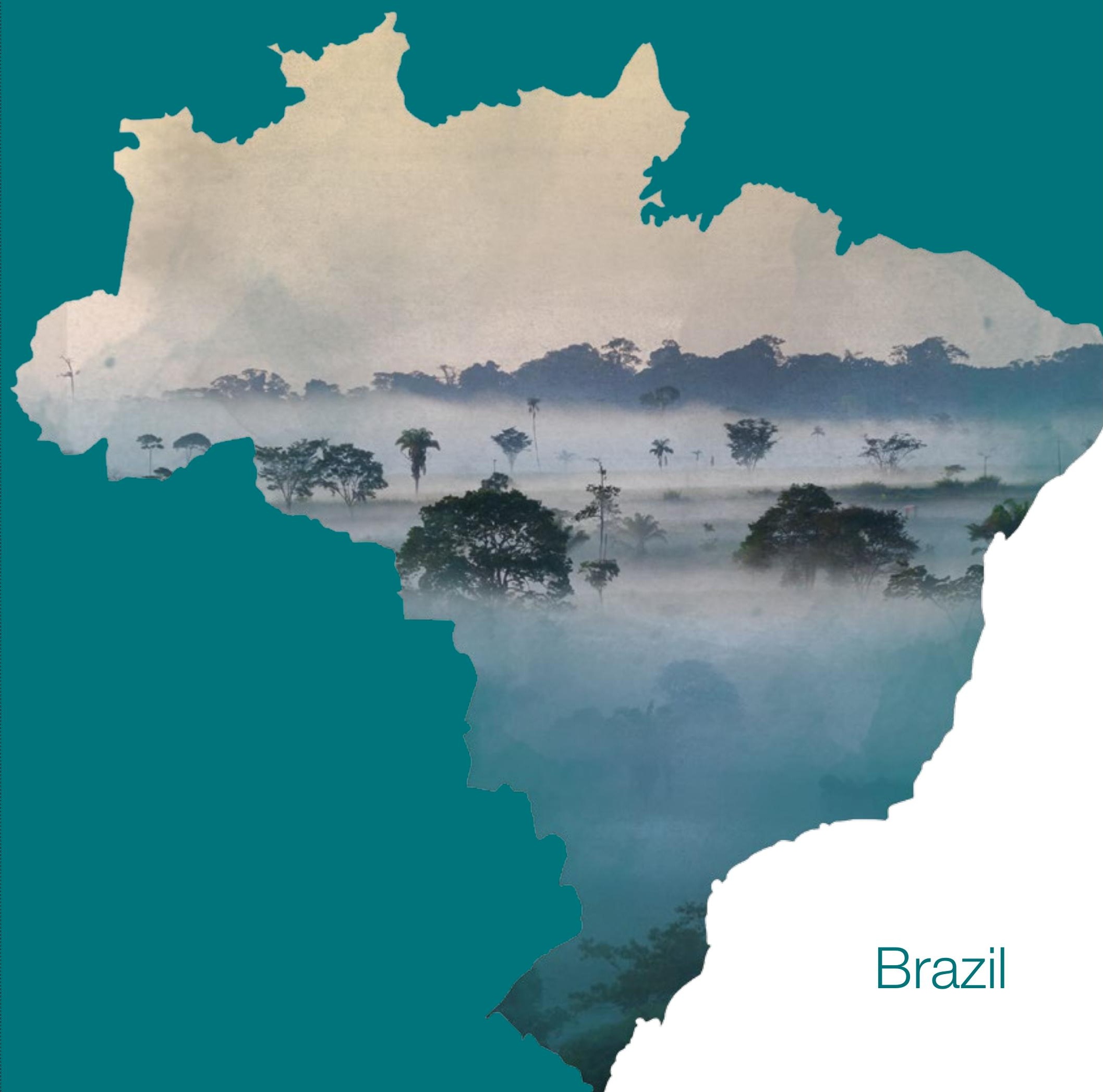




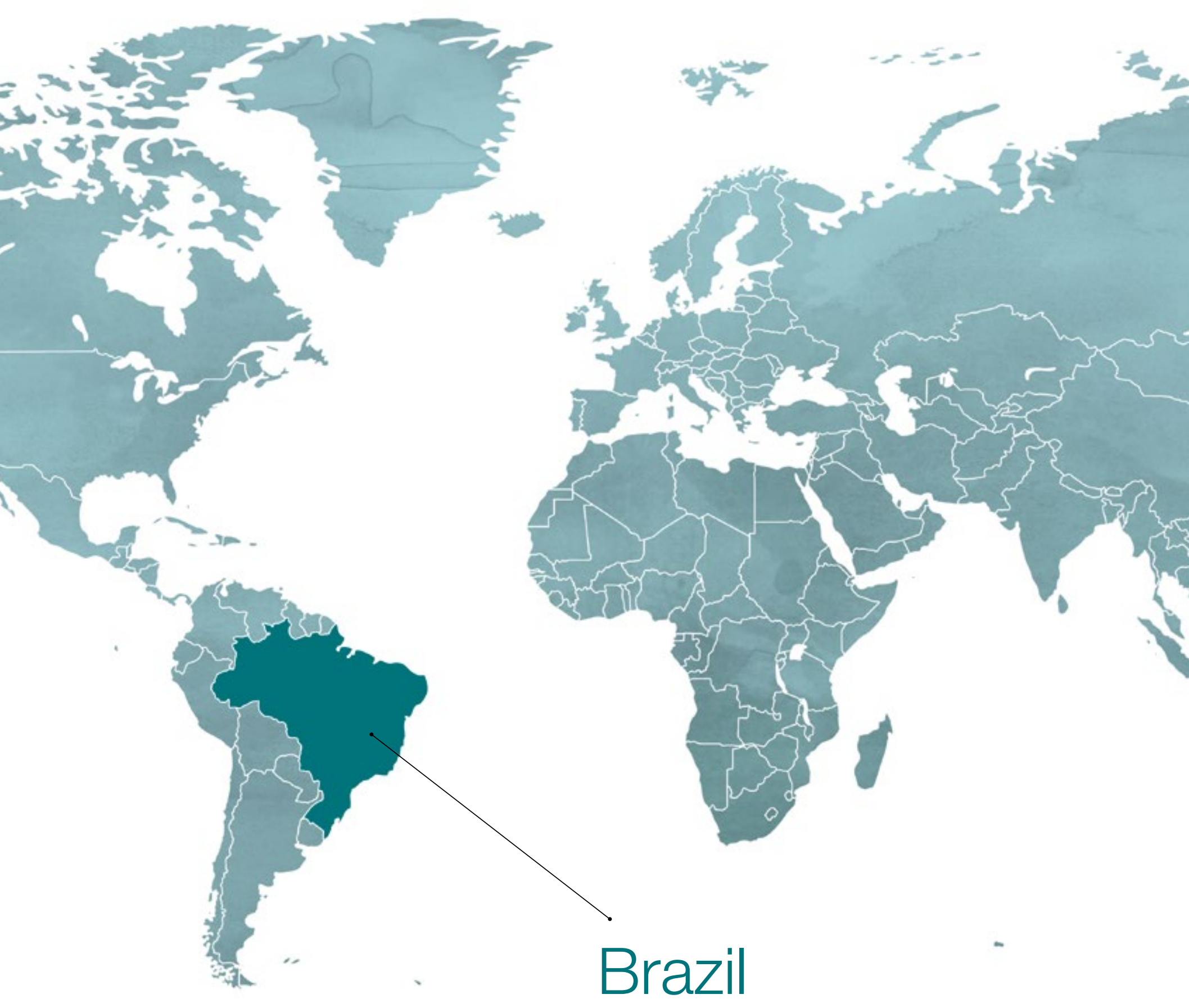

Country in South America

Size: cca 8,515,767 km²

Population: 200.4 million (2013, World Bank)

Capital: Brasília 


\section{Introduction}

During the last few decades human activities have rapidly depleted natural resources in the Brazilian Amazon, leading to the loss of 75 million hectares of forest and related ecosystems services (INPE, 2015). Approximately $60 \%$ of this deforested area was converted into pasturelands (EMBRAPA \& INPE, 2014). However, lack of adoption of proper livestock management practices resulted in gradual loss of pasture productive capacity (Dias-Filho, 2014), leading to degradation and abandonment of approximately 10 million hectares of pastureland (EMBRAPA \& INPE, 2014). This degraded area is spread within both large and small properties, but it is in the latter that the underuse or abandonment of areas engenders most negative socioeconomic impacts.

In the Amazon ranching is no longer confined to large-scale landowners, but has grown among other groups (Gomes et al., 2012). Particularly, agriculturalist smallholders who historically focused on crop cultivation have turned to cattle (Walker et al., 2000; Perz, 2002; Ludewigs et al., 2009; Pacheco, 2009). This was not only the result of price instability of agricultural produce, but was also influenced by increased demand from emerging regional markets for beef (Faminow, 1998; Barreto et al., 2005; Nepstad et al., 2006; Smeraldi \& May, 2008). Smallholders' adoption of cattle ranching practices raises concerns about livelihood systems transformations and food security, in addition to environmental costs of ranching expansion in the region.

Looking for a paradigm shift from unsustainable land use practices leading to degradation or deforestation to a sustainable model of agricultural production and food security to small farmers, The Nature Conservancy and partners have been working since 2011 to promote restoration of degraded pastures. This restoration is being implemented with cocoa (Theobroma cacao)-based agroforestry systems (AFS) in São Félix do Xingu (SFX), a municipality almost the size of Portugal, located in the eastern portion of the Brazilian Amazon. Intended to become a large-scale restoration initiative, this project aligns with Aichi Target 15 of the United Nations Convention on Biological Diversity, an international instrument for the conservation and sustainable use of biodiversity. It is also in line with the Bonn Challenge, a global restoration initiative that has established a goal of restoring 150 million hectares of deforested and degraded land globally by 2020, as well as with the New York Declaration on Forests, which expanded this goal to 350 million hectares restored by 2030 .

Finding ecological, economic and food security alternatives for small landholders is, however, a great challenge in the Amazonian frontier region (Gomes et al., 2008), especially 
when these alternatives involve forest landscape restoration (FLR), which is in the counter flow of deforestation practices adopted so far. In this paper, besides presenting the specific challenges of FLR with smallholders in the study region, an innovative, participatory approach (participatory demonstration unit - PDU) is described, and promising results in terms of adoption by farmers, positive economic returns and expansion of interested farmers are discussed. 


\section{Challenges of forest landscape restoration}

Located in the Arc of Deforestation, one of the most deforested regions of the Amazon (Figure 1), São Félix do Xingu municipality occupies 8,421,302 hectares, and has an estimated population of 111,633 inhabitants, equally distributed between rural and urban areas (Diário da União, 2014). Approximately 60\% of the area of SFX is situated within protected areas and indigenous lands, which have been playing a very important role in preventing more deforestation in the municipality. Indeed, $78 \%$ of SFX territory is still covered by ombrophilous forest, either forming large blocks within protected areas and indigenous territories or fragmented in the unprotected areas.

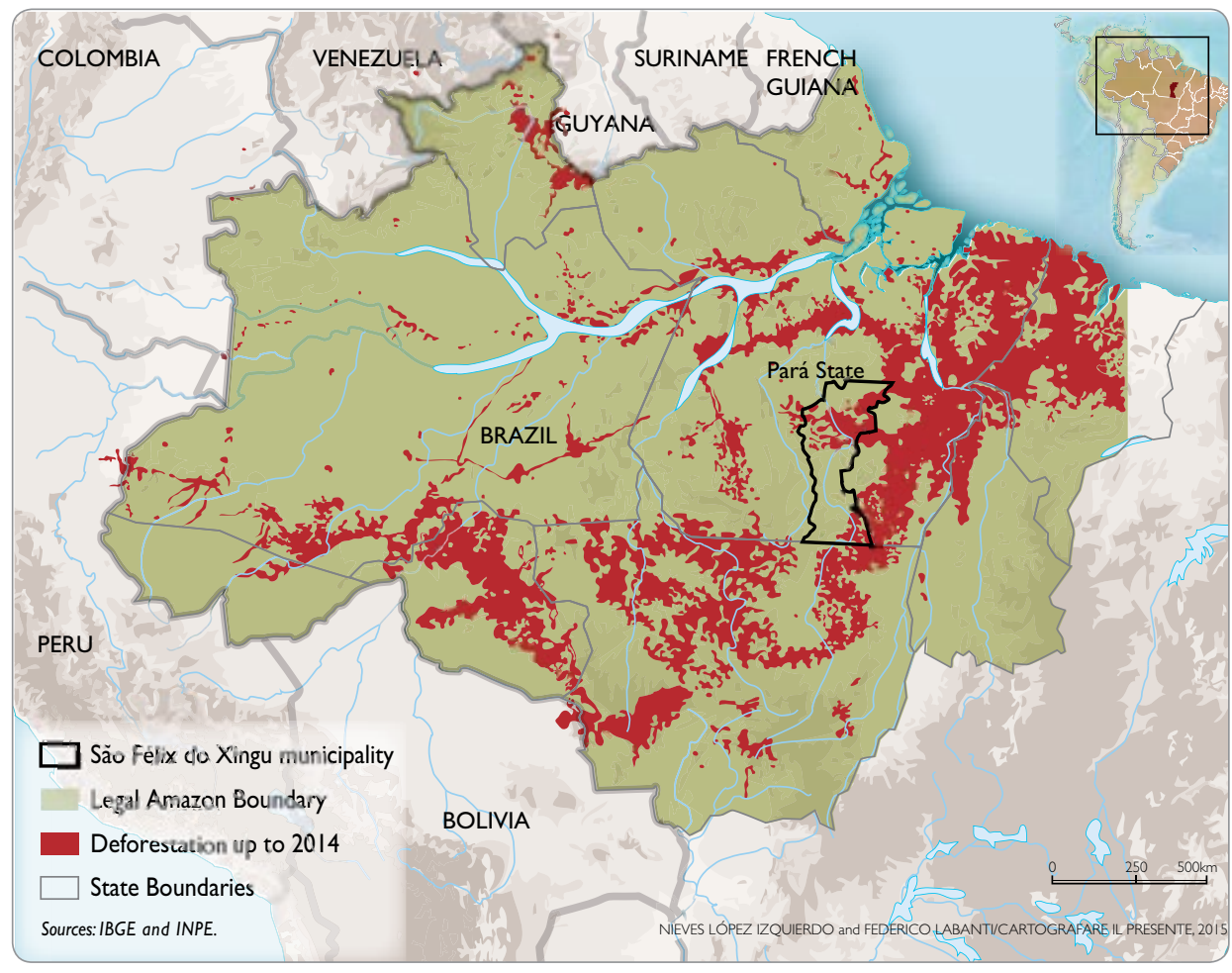

Figure 1.

Map of the Legal Amazon region, in Brazil,

highlighting São Félix do Xingu municipality, within the Arc of Deforestation 
As in other parts of the Amazon, land ownership in SFX is highly unequal. Small farms, defined as those having 300 hectares or fewer, represent $75 \%$ of properties, but only cover $18 \%$ of the total private land (The Nature Conservancy, unpublished data). Around $40 \%$ of these small farms are located in settlements originated from government-sponsored colonization projects or from the redistribution of large private landholdings. While settlers often hold documentation that authorizes their land occupation, official titles are less common. The lack of official titles is also very common among the small farms located outside the settlements.

In the last few decades, SFX territory went through an intensive occupation, which led to a significant conversion of native forests. In successive and overlapping waves, traditional riverside residents were joined by miners and loggers (1980s), migrant smallholder colonists (early 1990s), and ranchers and land speculators (early 2000s) (Schmink et al., 2014). As a consequence of a disordered occupation, SFX was included in the Environmental Ministry blacklist of the most deforesting municipalities in the Amazon, mainly due to extensive cattle ranching expansion. With a herd that increased from 30,000 to 2.3 million animals between 1997 and 2013, SFX became a top cattle producer in Brazil. Although pasture expansion was more evident in medium to large properties, small landholders also converted their lands into pasture. This small-scale forest clearing, commonly known as social deforestation, has historically happened in colonization projects, where the government's land reform policy was not accompanied by the provision of sustainable economic alternatives or technical assistance. On the contrary, in these settlements forest clearing was promoted, and perceived, by government agents as proof of land occupation; whereas subsistence agriculture was perceived as a marginal activity.

In the absence of sustainable and profitable agricultural land use alternatives, small farms have increasingly adopted cattle ranching, following the practices used in larger farms, based on successive processes of slash-and-burn of primary and secondary forest for the establishment of pastures. However, contrary to large landholders, the small ones usually own a much smaller herd, often for the production of dairy products or functioning as savings, as well as providers of calves for fattening to large ranchers. Additionally, pasture rental arrangements are also common in SFX, leading to the overexploitation of small pasture areas. With no access to best practice techniques or to financial resources, smallholders often witness a decreased productivity of most of their land, compromising its environmental, economic and social sustainability (Tourrand \& Veiga, 2003).

Indeed, by 2014 , on average, $71 \%$ of the area occupied by small properties in SFX had been deforested, whereas in medium and large properties mean deforestation was 59\%. This finding is consistent with the higher deforestation rates observed, in the last five years, 
in settlements (proportionally to the areas they occupy), in comparison with properties outside settlements (Figure 2). This is a different trend from the one observed in the whole municipality that shows a sharp decrease in deforestation rates in SFX in the last ten years (Figure 3). In parallel, the size of the deforestation plots have also decreased, particularly after 2009, when larger plots (> 500 hectares) started to occur sporadically, and most of the deforestation observed started to occupy areas smaller than 25 hectares (Figure 3).
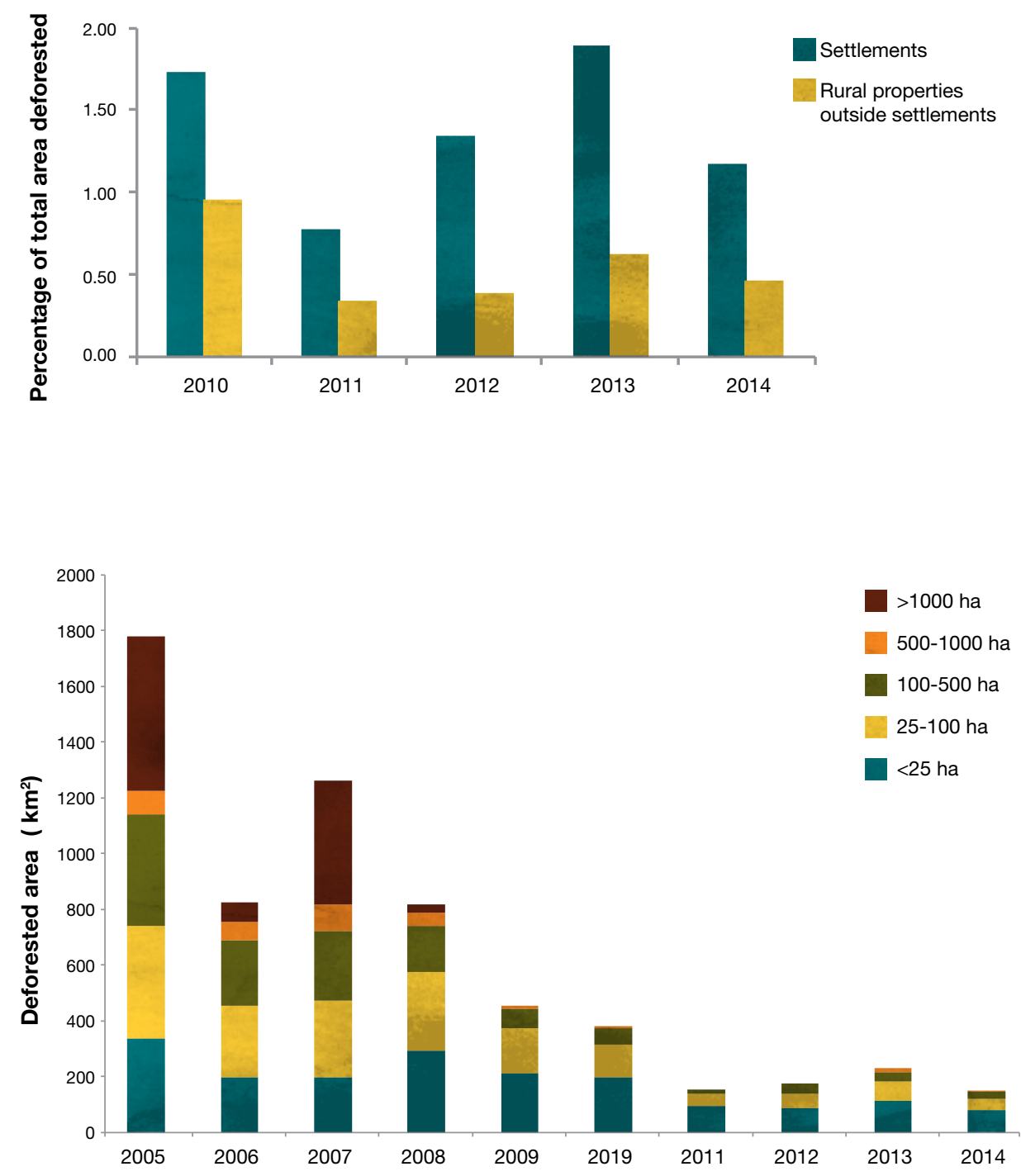

Figure 2.

Annual deforestation trends in terms of percentage of total area of settlements and of rural properties outside settlements

Figure 3.

Annual deforestation trends in São Félix do Xingu municipality total values and in terms of deforestation plot size 
Perceived by smallholders as the main opportunity to increase income, cattle raising has become unsustainable and a major challenge in achieving food security and countering deforestation. Changing this paradigm is not straightforward, given the complexity of the Amazonian frontier region. Involved is not only securing access to technical and financial support, but finding alternatives tailored to distinct socioeconomic, cultural and environmental realities, such as those found in SFX. In this context, cocoa-based agroforestry in degraded pasture is presented here as an alternative that draws on the knowledge and specific needs and socioeconomic conditions of small farmers, and that adopts an innovative approach to seek scale (participatory demonstration units), which encompasses a large number of neighbouring farmers.

\section{Opportunities for cocoa-based agroforestry systems in São Félix do Xingu}

The southeastern Pará State region, including SFX, is defined as a major expansion area by Brazil's Executive Commission for Cocoa Farm Planning (CEPLAC). Indeed, the adoption of cocoa AFS as a restoration alternative to degraded pasture by small farmers in this region is aided by a number of factors:

1. Excess of degraded and abandoned pasture land, which represents a threat to food security for small landholders;

2. Favourable prospects for cocoa on the national and international markets including the expectation of a global cocoa supply gap (Schroth et al., 2015);

3. Pará State programme for the development of the cocoa supply chain, which aims to transform the Pará into the largest Brazilian state producer of cocoa by 2023;

4. Environmental policies obliging land owners to reforest excess cleared land with native trees, with agroforests based on the native cocoa tree being an economically attractive option; and

5. Favourable biophysical conditions: i) humid tropical climate, with an average annual temperature of $26^{\circ} \mathrm{C}$ and annual rainfall between $1,800 \mathrm{~mm}$ and 2,200 $\mathrm{mm}$, favourable to cocoa cultivation (Wood \& Lass, 2001); ii) high soil fertility covering more than $60 \%$ of unprotected areas in SFX; the main soil suitable for cocoa giving their nutrient status and lack of physical restrictions are eutrophic subtypes of Argissolos, Neossolos Fluvicos and Nitossolos in the Brazilian soil classification, corresponding mainly to Acrisols, Fluvisols, and Nitisols, respectively, in the international classification (Schroth et al., 2015) (Figure 4). 


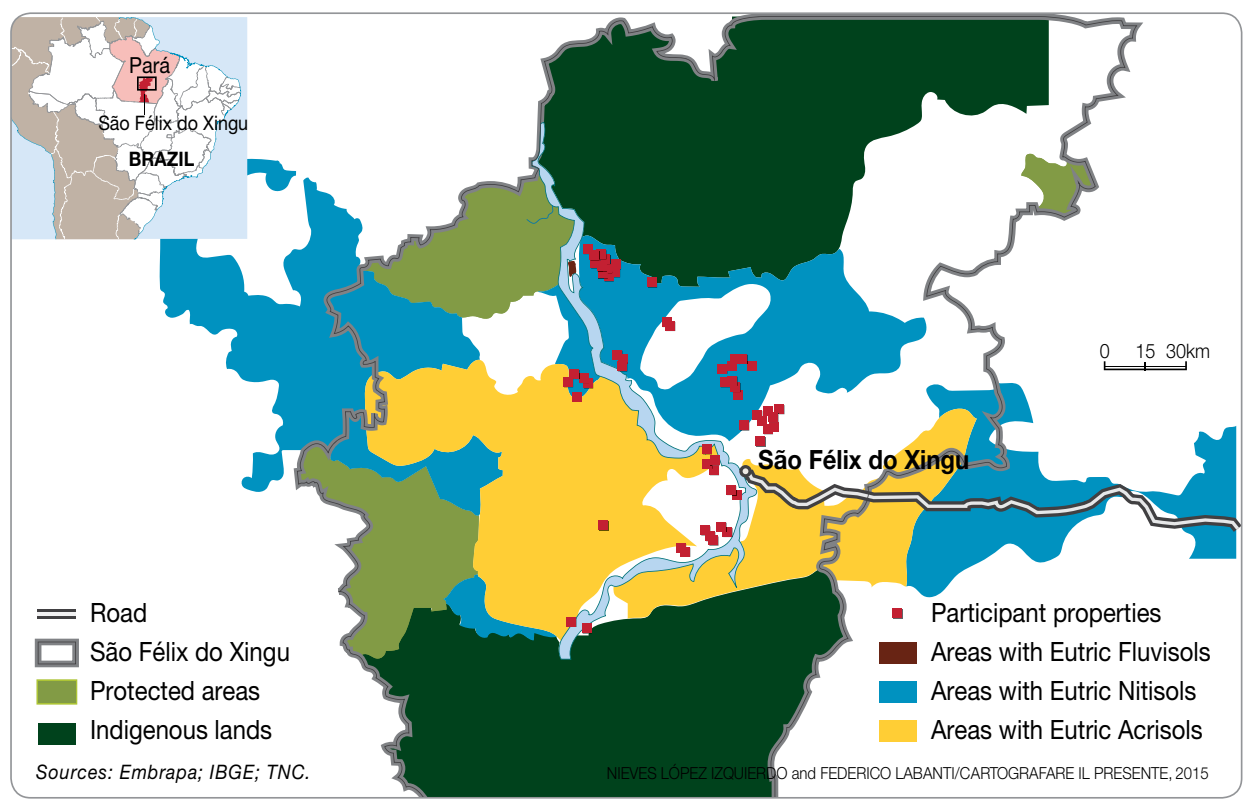

Note: Areas with soils of high chemical fertility (shown in brown, green and orange) are potentially suitable for planting cocoa (Theobroma cacao); those not suitable for cocoa are shown in white.

Additionally, the adoption of cocoa-based AFS generates significant environmental benefits. In these forest-like systems, cocoa forms the understorey below a canopy of companion trees (Schroth et al., 2004). These trees fulfil a range of functions including shading and microclimatic protection of young cocoa trees, but can also play productive roles (timber, fuelwood, fruits, etc.), maintain soil fertility and host pollinators and predators of cocoa pests (Schroth \& Harvey, 2007; Tscharntke et al., 2011). Moreover, they provide broader ecosystem services keeping water, energy and nutrient cycles closer to those of forest ecosystems, and increased biodiversity compared with monoculture systems (Cassano et al., 2009; Tscharntke et al., 2011; Waldron et al., 2012). Finally, in terms of climate change, cocoa-based AFS contributes both to increased carbon sequestration (Schroth et al., 2015), and reduced emissions (up to $135 \mathrm{Mg}$ carbon per hectare in SFX, according Schroth et al. (in press) compared with the historically common scenario of planting cocoa after forest clearing.
Figure 4.

Soil types, participant properties, indigenous lands and protected areas in São Félix do Xingu municipality, Pará State, Brazilian Amazon 


\section{Forest landscape restoration intervention: Innovative participatory approach}

\section{Implementing agencies}

The Nature Conservancy, with financial support from Cargill and the Norwegian Agency for Development Cooperation (NORAD), has been working since 2011 to promote restoration of degraded pastures with cocoa-based AFS as a sustainable agriculture alternative for small farmers. More specifically, the project sought to develop a cocoa supply chain that promoted sustainable economic development and food security for smallholder farmers, while restoring degraded lands and avoiding deforestation. This project took a multistakeholder approach, engaging a grassroots organization, government agencies and the private sector. A partnership was established with Cargill, the Alternative Cooperative of Small Rural and Urban Producers (CAPPRU), the São Félix Municipal Bureau of Agriculture (SEMAGRI), and the Ministry of Agriculture's Cocoa Research and Technical Extension Agency (CEPLAC). Each partner brought its own expertise and skills to the initiative, and exerted distinct roles. For example, Cargill was key in identifying constraints to production and in engaging CEPLAC, besides providing financial support. CAPPRU exerted an important role in the mobilization of participants and in negotiating the production. CEPLAC

- Brazil's cocoa germplasm bank, with decades of research to improve cocoa varieties - provided the cocoa seeds to farmers. SEMAGRI played a role in strengthening the local technical assistance network. The Nature Conservancy, with the role of achieving a balance between economic opportunities and conservation of natural resources, led the project planning and implementation, and contributed with a project coordinator and two field technicians to work alongside smallholder farmers, providing technical assistance on the ground, and farmers' capacity-building in forest restoration with cocoa-based AFS. The Nature Conservancy was also responsible for the supply of seeds and seedlings of noncocoa species (annual crops, and fruit and timber trees) to the participant farmers.

\section{Stakeholder mobilization and involvement}

Partnership with CAPPRU was critical in promoting a series of smallholder mobilization and information meetings and in encouraging participants' commitment to the initiative. 
Participants' adhesion to the project was also promoted on a one-by-one basis by the technicians, who during their field trips, invited neighbours of participant farmers to learn more about the project. As a result of this mobilization, adhesion to the project was gradual, with the engagement of 31 small landholders by the end of 2013 and an additional 30 during 2014, and none quitting.

\section{Description of interventions}

Figure 5 shows a flowchart summarizing the main activities developed in the establishment of cocoa-based AFS in small farms in SFX, and Figure 6 illustrates some of these activities. Details of the activities are provided below.

Figure 5.

Flowchart indicating the main activities involved in the implementation of the cocoa-based AFS in São Félix do Xingu

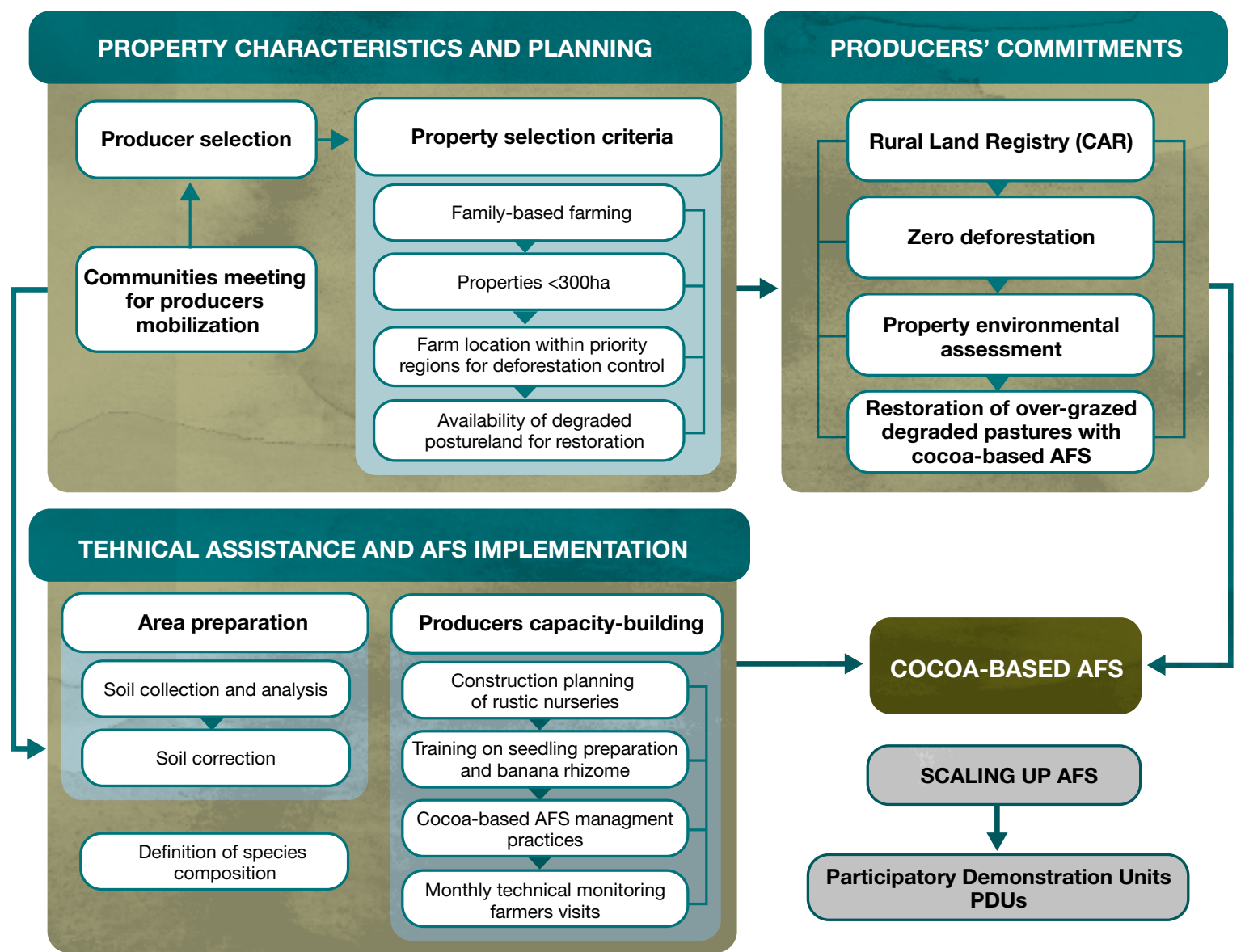


Figure 6.

Cocoa-based AFS

implementation:

A) area preparation;

B) construction of rustic nurseries;

C) training on seeding preparation;

D) cocoa, fruit and timber trees production in a property (photo credits: Erivaldo Alves and Márcio Queiroz)
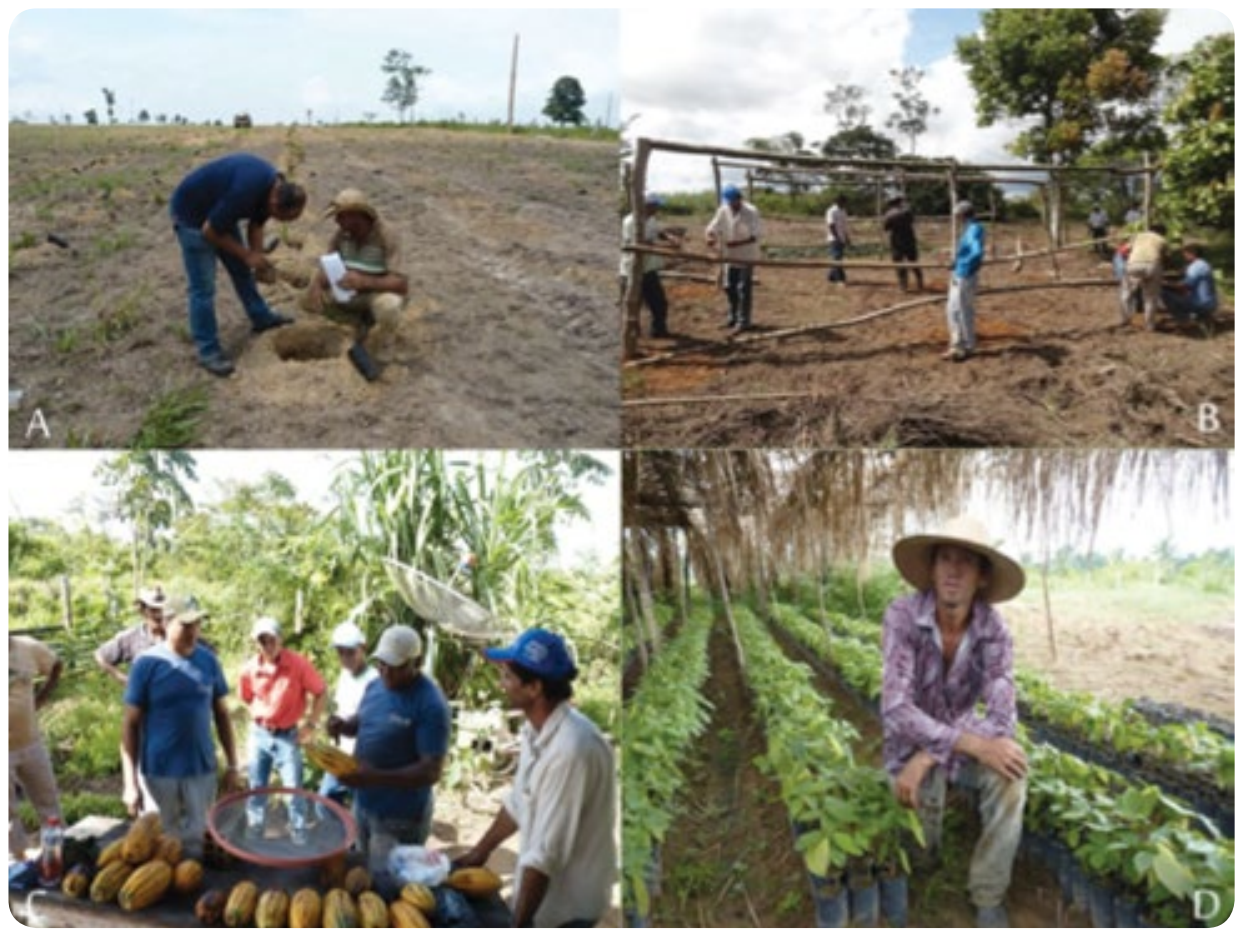

Properties selection and producers' commitments: Following the mobilization and information process, 61 small landholders were selected to participate in the project. The selection criteria took into account not only farm size and availability of degraded pastureland, but also its use in family-based agriculture production. Priority was given to lands located in areas with high recent incidence of deforestation, and to farmers at higher food security risk, identified in the initial field socioeconomic assessment. The selected producers had to commit to limit the implementation of cocoa-based AFS to degraded pasture, with no additional deforestation of their lands. All participants were also required to obtain, in case they had not yet, the rural land registry reference, which works as an official ID of each property, containing georeferenced information of its land use; this is the basis for the verification of compliance with environmental laws. Producers were also responsible for all labour inputs; and the only financial charge they had was with the fuel used during farming. Once these commitments were accepted, a detailed environmental diagnostic of each property was elaborated with the use of high-resolution satellite images (RapidEye $5 \mathrm{~m})$ and field validation. This assessment was used to identify, georeference and quantify 
different land use and land condition, as well as the presence of water sources and water bodies, serving as a basis for planning the restoration interventions (Figure 7).

Technical assistance and cocoa-based AFS implementation: After the selection of the restoration areas, the first step was soil collection and analysis and, if needed, soil correction. Activities were then focused on producers' capacity building. A series of 10 group meetings was held, each one focusing on a different topic. Participation in these meetings was optimized by promoting them at different locations to ensure access to all small farmer participants. Two field technical assistants performed monthly visits to the farms, providing additional technical assistance, and monitoring the development of the cocoa-based AFS.

From 2012 to 2014, the project focused on implementing cocoa-based AFS using a traditional approach, based on individual visits and technical assistance, and conducting collective training events. For scaling-up this initiative, setting up a much broader rural technical assistance approach for cocoa-based AFS, and addressing the concerns about rising implementation costs, from 2015 a project management decision was made to adopt a new design - the participatory demonstration unit (PDU) approach.

The PDUs, with the landowners' consent, become the central point for technical assistance in a region, allowing for a more efficient interaction with a greater number of small farmers located within a $15-\mathrm{km}$ radius (Figure 8). The selection of PDUs takes into account landowners leadership and regional potential for new farmer participation in the project. The PDUs aim at promoting greater social cohesion within neighbourhood groups, combining farmers' knowledge with technological components to define the appropriate cocoa-based AFS. They also promote joint experimentation at the local level with rural technical extension and research institutions, for the generation and adaptation of technologies, thus promoting the continued training of smallholders.

Definition of cocoa-based AFS species composition: The selection of species involved evaluation discussions between technicians and groups of farmers, or farmers individually. Decision making considered aspects related to forest restoration, food security, market and profitability, competition between plants, and family labour availability and/or needs, in addition to species lifecycle. Because these decisions influence medium- and long-term outcomes, this assessment of the AFS composition increased the chances of benefits for producers. Furthermore, the selected species were already in demand and/or cultivated randomly in the region. The change consisted in cultivating them within cocoabased AFS. 
Figure 7.

Property environmental

diagnostic

\begin{tabular}{|l|c|c|}
\hline \multicolumn{2}{|c|}{ Property environmental diagnostic } \\
\hline Feature & AREA (ha) & $\%$ \\
\hline Forest remnant & 35,3 & 49,6 \\
Pastureland & 35,9 & 50,4 \\
Cocoa-based agroforestry system & 4,35 & 6,12 \\
Riparian area & 9 & $12,6 \quad$ A \\
\hline
\end{tabular}
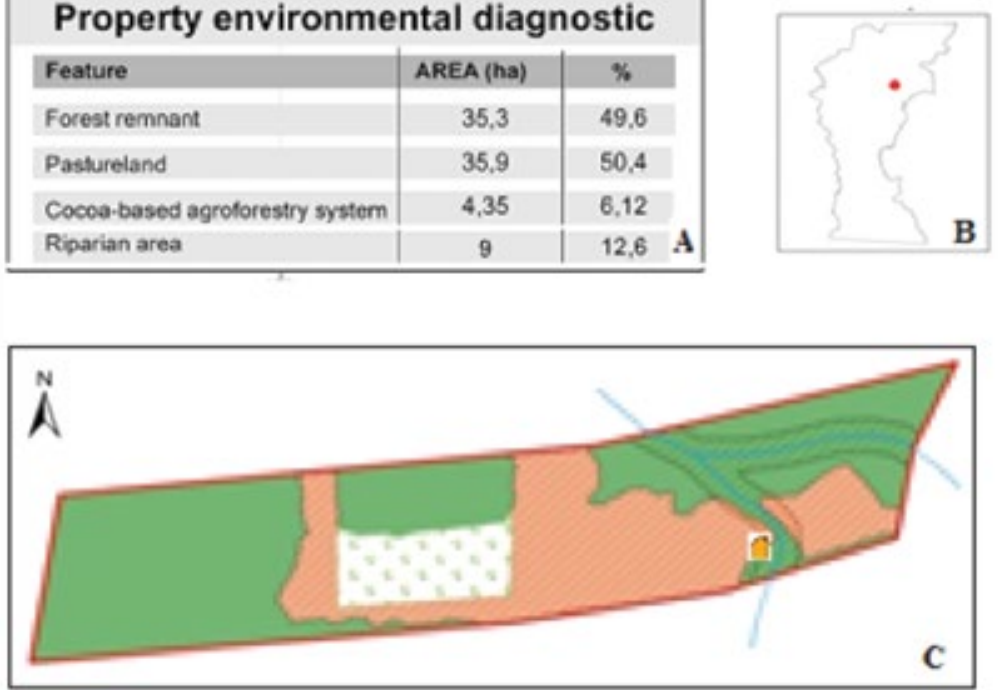

\section{Legend}

$\square$ Property boundaries

Forest remnant

Pasturelands

Riparian area

Cocoa-based agrolorestry system

\section{Family house}

- Water source

Streams

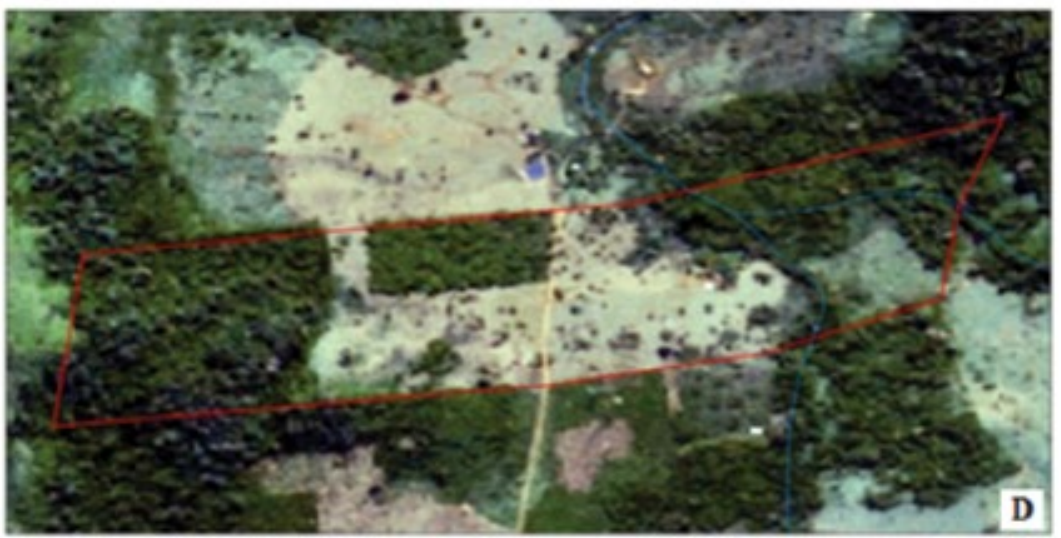

Note: Environmental diagnostic of a smallholder (A), located in São Félix do Xingu municipality (B), showing and quantifying the property land use (C), mapped with the use of spot satellite image of 5-m resolution (D). 


\section{Results and analysis}

\section{Participant properties}

In 2013 and 2014, 61 properties were engaged in the project, half of which were located in settlements (São José, São Sebastião, Campo Verde, Tancredo Neves and Pombal) (Figure 8). An environmental diagnostic of each participant farm was conducted following their adhesion to the project. An example of this diagnostic is shown in Figure 7, and a summary of the land use in these farms is presented in Table 1 . The total area of the engaged properties was approximately 5,000 hectares, and the size of individual properties ranged

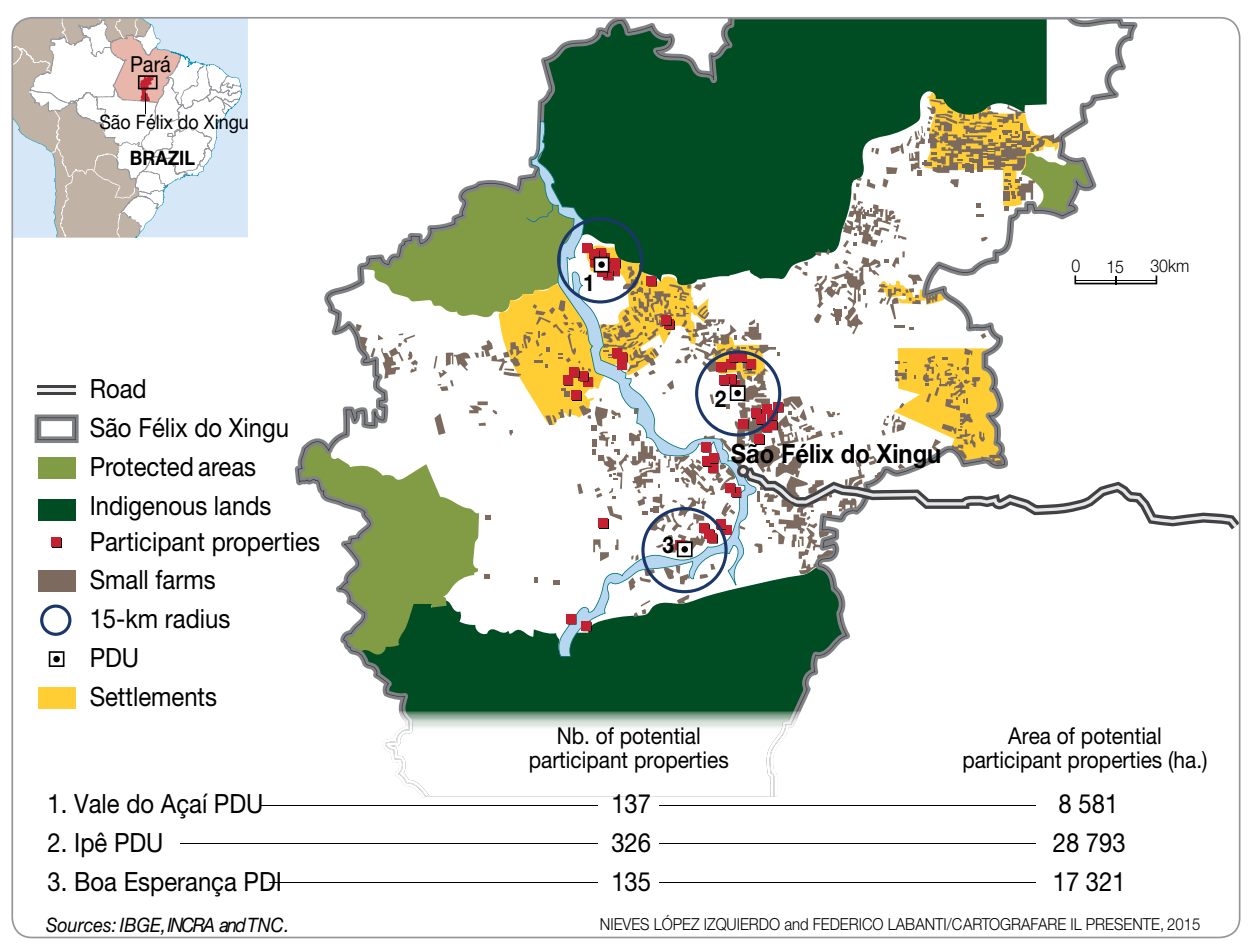

Figure 8.

Distribution of the properties initially engaged in the cocoa FAS project in São Félix do Xingu

Note: Three PDUs, including small farms ( $<300 \mathrm{ha}$ ) within a 15-km radius of the PDUs are shown. The map also illustrates the variety of land tenure in the municipality: indigenous lands, protected areas, small farms within and outside settlements, and areas occupied by medium and large properties (white). 
from 35 to 220 hectares, and averaged $79.2 \pm 43.1$ hectares. Deforestation varied from as low as 3\% to as high as 99\% of the entire property, with a mean of 53\% (41.9 hectares). Most of these areas were originally intended to be used as cattle ranching, and $60 \%$ of them were in different stages of degradation. Indeed, the majority of this pastureland had a history of use between 15 and 20 years, without any management, much higher than the period of five years from which, without proper maintenance, productivity begins to decline in the Amazon (Dias-Filho et al., 2001). In settlements, forest conversion for agriculture and livestock used to be required by the government as an incentive for maintenance of land tenure (Schmink \& Wood, 1992; Pacheco, 2009). Additionally, some settlements were created in old livestock farms expropriated by the government for purposes of agrarian reform, and thus small farmers had few options other than raising cattle on already established pasturelands.

Despite the pastureland condition, approximately $90 \%$ of the participants kept from 5 to 10 heads (only one of them had more - 30 heads) of dairy cattle in their lands. This type of herd plays an important role in ensuring food security, helping in the family diet, but only generates a little income through local selling of milk and cheese. In this context, adhesion to the cocoa AFS project has being perceived by smallholders as a sustainable alternative to augment their income and improve their livelihoods.

\begin{tabular}{|c|c|c|c|c|c|c|}
\hline \multirow{6}{*}{$\begin{array}{r}\text { Table } 1 . \\
\text { Main land use } \\
\text { characteristics of the } \\
61 \text { participant farms }\end{array}$} & & Total & Average & $\begin{array}{l}\text { Standard } \\
\text { deviation }\end{array}$ & Minimum & Maximum \\
\hline & Farm size (ha) & 4.987 & 79.2 & 40.3 & 35.1 & 219.5 \\
\hline & Deforested area (ha) & 2.594 & 41.9 & 26.7 & 3.1 & 138.5 \\
\hline & Native forest remnant (ha) & 1.811 & 28.0 & 28.8 & 0 & 90.2 \\
\hline & Regeneration area (ha) & 368 & 6.2 & 6.1 & 0 & 28.1 \\
\hline & Cocoa-based AFS area (ha) & 238 & 3.9 & 2.0 & 1.5 & 10.0 \\
\hline
\end{tabular}

The restoration of degraded pastureland with cocoa-based AFS encompassed 238 hectares. The mean individual restoration plot was $3.9 \pm 2.0$ hectares. The minimum plot size was 1.5 and the maximum 10 hectares. Plot size was based on family socioeconomic profile, including property size, family-based labour availability and cocoa-based AFS management demands. It was also a project risk management decision to keep initial plots relatively small, considering small farmers' initial insecurity about producing cocoa-based AFS on degraded pastureland, given their very limited investment capacity and labour force. 


\section{Cocoa-based AFS composition}

Table 2 shows the options for temporary annual crops, arboreal fruit trees and timber trees selected by small farmers for the composition of cocoa-based AFS. Fifteen producers' preferred species were identified and distributed as follows: two annual temporary crops, five fruit trees, and eight timber trees. At least 50 seedlings of each selected fruit and timber tree were planted per hectare for the AFS composition.

\begin{tabular}{|c|c|c|}
\hline Tree species in cocoa-based AFS & $\begin{array}{l}\text { Number } \\
\text { of plants }\end{array}$ & $\begin{array}{l}\text { Spacing } \\
\text { (m) }\end{array}$ \\
\hline \multicolumn{3}{|l|}{ A: Annual crops } \\
\hline Cassava (Manihot esculenta) & 5,000 & $2 \times 2$ \\
\hline Maize (Zea mays) & 40,000 & $1 \times 1$ \\
\hline \multicolumn{3}{|l|}{ B: Fruit-bearing plants } \\
\hline Banana (Musa sp.) & 1,111 & $3 \times 3$ \\
\hline Cocoa (Theobroma cacao L.) & 1,111 & $3 \times 3$ \\
\hline Açaí (Euterpe oleracea) & 69 & $12 \times 12$ \\
\hline $\begin{array}{l}\text { Golosa (Chrysophyllum cuneifolium } \\
\text { (Rudge) A.C.D.) }\end{array}$ & 44 & $15 \times 15$ \\
\hline Cajazeiro (Spondias mombin L.) & 11 & $30 \times 30$ \\
\hline \multicolumn{3}{|l|}{ C: Timber trees } \\
\hline Aroeira (Schinus molle L.) & 44 & $15 \times 15$ \\
\hline Andiroba (Carapa guianensis) & 68 & $12 \times 12$ \\
\hline Copaiba (Copaifera spp.) & 17 & $24 \times 24$ \\
\hline Ipê (Tabebuia serratifolia Rolfe) & 48 & $18 \times 18$ \\
\hline Jatobá (Hymenaea courbaril) & 48 & $18 \times 18$ \\
\hline Mahogany (Swietenia macrophylla) & 48 & $18 \times 18$ \\
\hline Tatajuba (Bagassa guianensis Aubl.) & 17 & $24 \times 24$ \\
\hline Seringueira (Hevea brasiliensis) & 204 & $7 \times 7$ \\
\hline
\end{tabular}

Table 2.

Species, number of plants and planting spacing defined for the agroforestry systems in 1 hectare

Among the initial annual crops, cassava (Manihot esculenta) and maize (Zea mays) stood out for their important role in food security for family-based farming (Figure 9). They are annual food crops intended for home consumption and animal feed, and the surplus goes to the internal state market. All farmers chose banana trees (Musa sp.) due to their provisional shading role for cocoa, and also for food security and the potential to generate income for three to five years before the cocoa started to produce (Figure 10). 
Figure 9.

Cocoa-based AFS in São Félix do Xingu

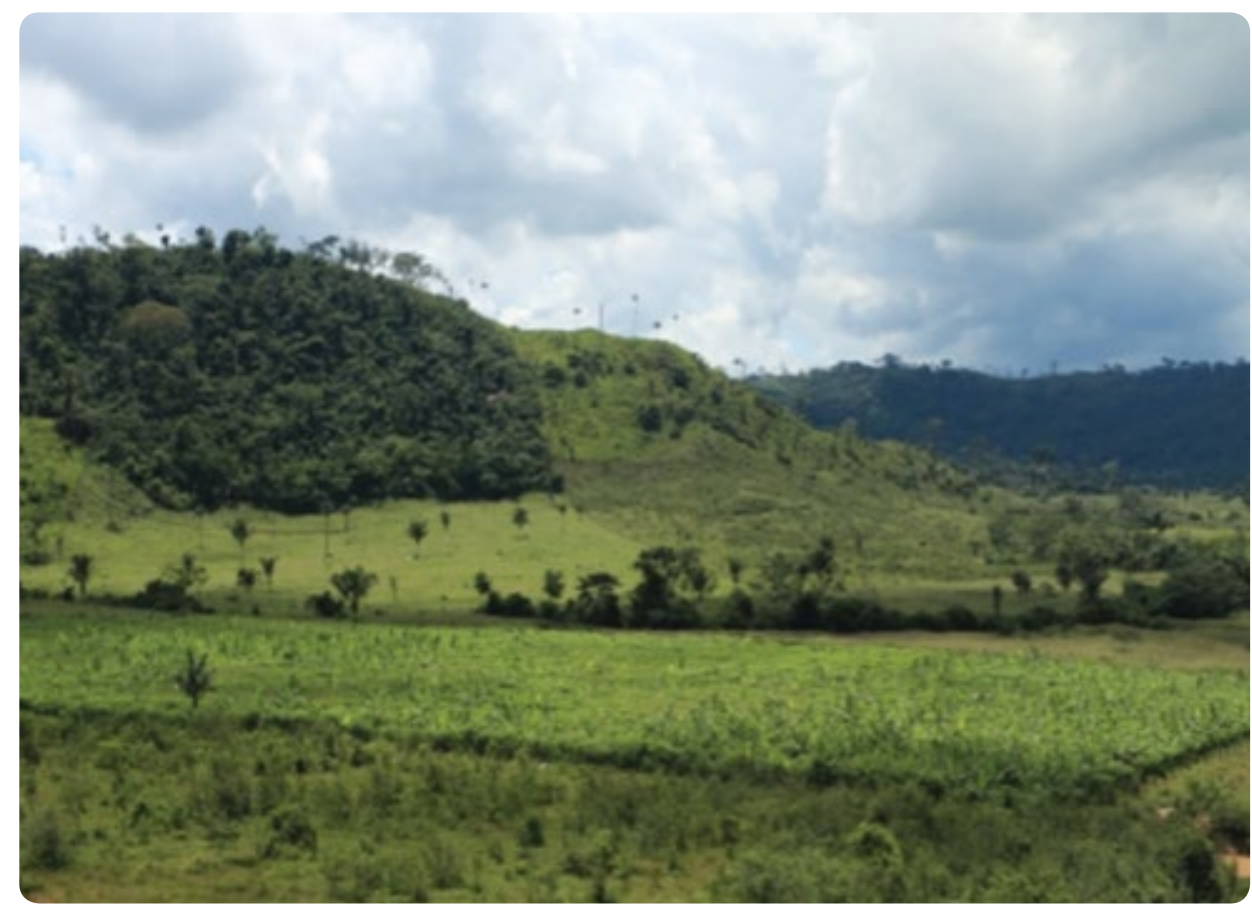

Note: In the centre of the picture, cocoa-based AFS in São Félix do Xingu municipality; eight months after the start of the project, showing cassava and banana; four-month cocoa and timber trees are not visible in the picture. In the lower part of the picture, a degraded and abandoned pasture with exposed soil can be seen (photo credit: Valério Gomes).

The most favoured fruit tree species were açaí (Euterpe oleracea) and golosa (Chrysophyllum cuneifolium (Rudge) A.C.D.). Açaí has a growing regional market demand, while golosa is popular among the local population for pulp and juice. The choice of species was also based on the farmer's socioeconomic profile. Those who already sold fruit at the municipal farmers' market chose more fruit species in order to expand their sales. Other farmers took into consideration the infrastructure and logistics of production and transportation. For example, about 30\% of farms lacked electricity, while others were located up to $170 \mathrm{~km}$ from the nearest town, in areas with almost inaccessible roads. Both factors generated constraints on market opportunities for fruit species.

The selected timber species were chosen partly for their role in providing permanent shade for the cocoa-based AFS. They also met the farmers' market expectations for reasons not related to logging. Other sources of economic value were stressed in the technical evaluation discussions. Due to the demand on the markets for its seeds, 


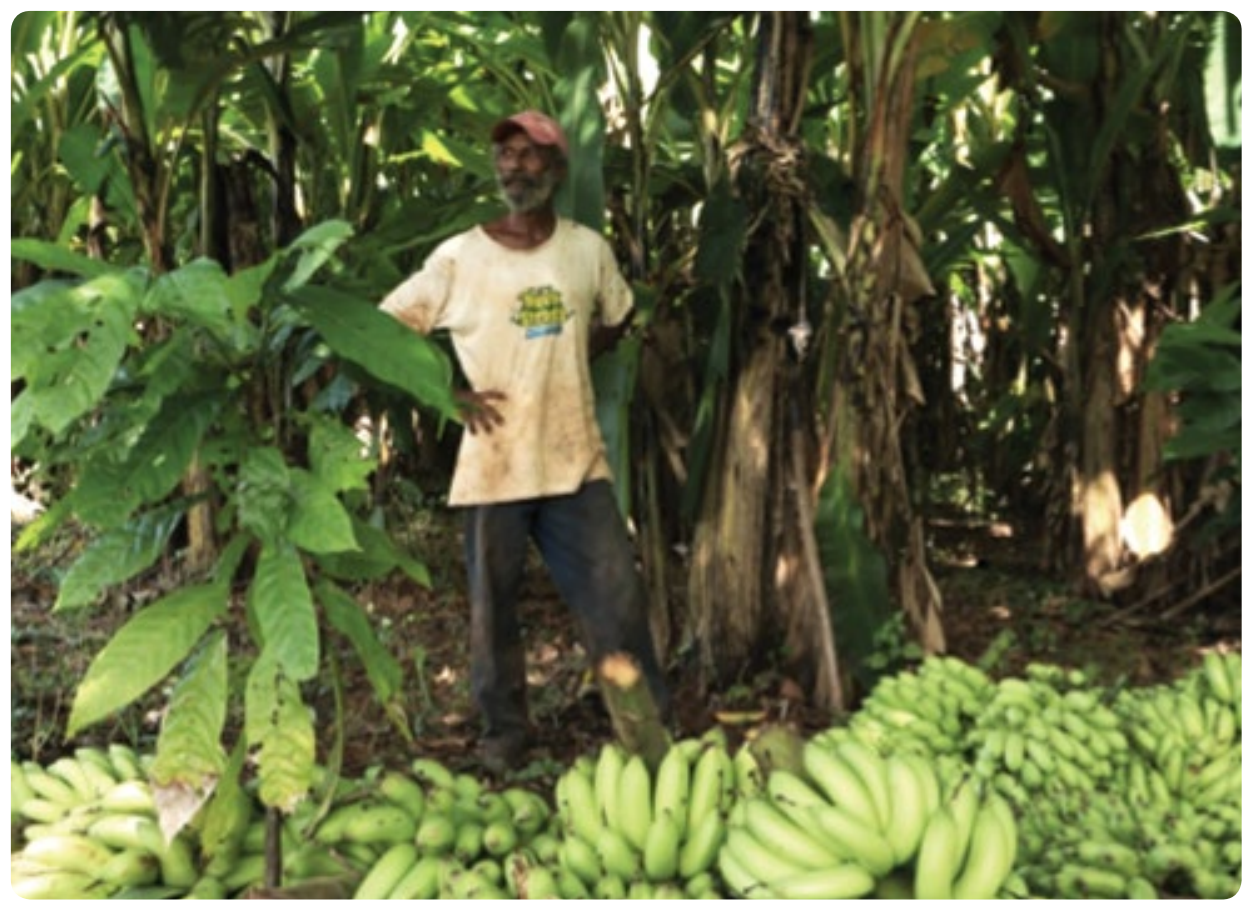

Figure 10.

Cocoa-based AFS in São Félix do Xingu municipality 18 months after adhesion to the project

Note: The first banana crop is shown, and, in the background, banana, cocoa and timber trees. At this stage, the maize planted at the start of the project had already been collected (photo credit: Valério Gomes).

mahogany (Swietenia macrophylla) was the farmers' most preferred species despite the fact that its harvesting is highly regulated. The copaiba (Copaifera spp.) and andiroba (Carapa guianensis) were also highlighted as commercially valuable for the extraction and sale of oil. Only aroeira (Schinus molle L.) was perceived as a species with good opportunity for logging. Due to the limited supply of timber in the region, wood for building fences and corrals is normally purchased in other regions of the state. Because aroeira is commonly used for this purpose, it has the potential to be commercially valuable in the future as timber.

\section{Economic return}

Economic return of cocoa-based AFS depends on a series of factors, including: cocoa area and age of cocoa trees; revenue from cocoa harvest, and fruit, timber and other produce sales from shade trees; cost of fertilizer and of other chemical inputs; cost of hired farm labour; and produce transport costs (Waldron et al., 2012). 
At this point of the project, no direct income has been generated yet by cocoa production itself, given that the cocoa trees are at most two years old; the same applies to timber production. However, the implementation of a cocoa-based AFS has allowed the generation of income from other initial crops, particularly cassava, maize, banana and other fruit-bearing shade trees. This potential for diversifying income generation was an essential strategy for managing risks of family farming production systems, ensuring an important economic return at the initial phase of the project.

Cassava, maize and banana were the preferred initial crops, being planted by all participant farmers in all cocoa areas. This preference is related to the fact that these are relatively fast growing crops, and either provide fast cash return or are important as human and livestock food. Cassava was the main income source during the first year of the project, being planted in October and harvested in April or October. The first crop was generally sold as a raw product, whereas the second was used for the production of flour, which was then sold. Maize was also planted in October, but harvested in January. A second planting was carried out by approximately $20 \%$ of the farmers in February and harvested in May. Only a small part of the crop was sold as a raw product. Maize was largely used internally on the farms, for family consumption and especially in animal husbandry, usually chickens and pigs, which, once fattened, were sold. Therefore, the main income from maize did not come from its direct sale, but was related to the added value generated by the weight gain of the sold animals. Banana was planted in September and harvested from September to December of the following year. Banana was particularly attractive to project participants because it could be sold to local schools through a federal programme, the National School Feeding Programme, which establishes that a minimum of $30 \%$ of produce served to students at public schools needs to come from local producers.

Mean cassava, maize and banana yields in the initial year of the cocoa-based AFS, and estimated generated gross income are presented in Table 3. First gross revenue was estimated at approximately US\$5,853 per hectare on an annual basis. Considering that

\begin{tabular}{|c|c|c|c|c|}
\hline \multirow{6}{*}{$\begin{array}{r}\text { Table } 3 . \\
\text { Average yield and gross } \\
\text { income from cassava, maize } \\
\text { and banana crops during } \\
\text { the first year of the cocoa- } \\
\text { based AFS in São Félix do } \\
\text { Xingu municipality }\end{array}$} & & Average yield (kg/ha) & $\begin{array}{c}\text { Mean price per kg } \\
\text { (US\$) }\end{array}$ & $\begin{array}{c}\text { Gross income per } \\
\text { hectare (US\$) }\end{array}$ \\
\hline & Cassava (raw) & 450 & 0.83 & 375 \\
\hline & Cassava (flour) & 1,800 & 1.07 & 1,926 \\
\hline & Maize & 1,100 & 0.23 & $253^{*}$ \\
\hline & Banana & 10,000 & 0.33 & 3,300 \\
\hline & Total & & & 5,853 \\
\hline
\end{tabular}

${ }^{*}$ Assuming that only $20 \%$ of the crop was sold. 
the size of restored pastureland plots ranged from 1.5 to 10 hectares (Table 1), mean gross income could vary from around US\$ 8,800 to almost US\$60,000.

Production costs of project participants are not available, but according to other studies also conducted in Pará State with cocoa-based AFS (Paraense et al., 2013; Sanguino et al., 2007), production costs at the pre-cocoa harvesting phase could represent $22 \%$ to $40 \%$ of the generated gross income. Therefore, being conservative, the net income generated by cassava, maize and banana crops during the first year of the cocoa-based AFS would be approximately US \$ 3,500 per hectare. However, this estimate does not include the added value of maize to livestock husbandry and its impact on the income generated by selling animals. In addition to the revenue from cassava, maize and banana sales, it should be considered that this produce, as well as consumption of small livestock, are important components of farmer families' subsistence strategies. Therefore, besides their commercial value, they are essential in terms of food security. It is also worth noting that the above estimates apply to the pre-cocoa harvesting phase and do not take into account all sources of household income, such as cash crop agriculture outside the AFS areas, livestock and milk production, and income from activities outside the property or from government benefits. Indeed, many small producers play an important role in the livestock production chain, serving as calf providers to large farmers in the region. In general their profitability is considered low, with the main gain being associated with fattening and sale of adult animals. Small dairy farms, such as the ones engaged in the project, also adopt this practice, but only sell male calves. However, dairy calves have an even lower market value because they tend to be smaller than beef calves. For instance, an eight-month dairy calf is sold for approximately US\$150, while a beef calf of the same age can reach a value up to $80 \%$ higher.

Despite some advantages of extensive cattle ranching (low labour demand, transport facilities and market, among others), many small farmers have realized through their own experience that raising livestock as the main alternative for generating income, on a small scale-basis, is very risky. Among the risks, are faster degradation of the soil and relatively high costs of pasture restoration, and uneven market relationships with large farmers or middlemen. Cocoa-based AFS, in the current socioeconomic context, is perhaps a main alternative that can out-perform livestock in terms of family income generation. From the first harvest season onwards, an annual production of $1,000 \mathrm{~kg} / \mathrm{ha}$ can be expected. At a selling price of US $\$ 2.50$ per kilo of cocoa beans, and a range of 1.5 to 10 hectares planted per farm, an income between US\$3,750 and US\$25,000 per year should be generated per farm, besides the revenue from fruits, woods and oils. In strict financial terms, cocoa AFS has a stable and growing market chain of value in the region, and so represents a 
profitable long-term alternative; even when all labour input costs are accounted for. Also, considering the many other factors, like the lack of job opportunities, the isolated location and marketing difficulties, these smallholders engaging in cocoa-based-AFS are doing well and building a sustainable agricultural future in the region. However, planting cocoa-based AFS in degraded pasture area has brought, initially, quite a number of uncertainties in the perception of producers, given that traditionally forest removal, and not forest restoration, has been widely used as an approach to extend the exploitation area within farms. Nevertheless, the prospects look promising. Some participants that adhered to the project in 2013 are expanding their AFS areas over degraded pasture without any subsidy, based on the experience they accumulated and on expectations of economic return. Furthermore, the initial results achieved by the current project participants are gaining visibility in their neighbourhoods and new demands to take part in the project have been received.

To scale-up the cocoa-based AFS, in a second phase of the project a new approach is being adopted. Participatory demonstration units, which comprise centres of technical dissemination and farmers' experience exchanges, are being implemented. Each PDU is founded on a successful participant in the first phase of the project, and is aimed to attract neighbouring farmers within a $15-\mathrm{km}$ radius (Figure 11). These PDUs promote: i) enhanced training and cooperation among neighbouring farmers; ii) knowledge exchange between different groups of small farmers to foster gradual changes in perceptions and practices; and iii) capacity building of rural technical assistants to reconcile technological issues with small farmers' specific needs and knowledge. Currently three PDUs, Vale do Açaí, Ipê and Boa Esperança, have been created throughout the municipality (Figure 8). A potential multiplier effect of these three PDUs is almost 600 small properties that fit key criteria (family-based farming, property < 300 ha) for participation in the project, and that together occupy an area of 55,000 hectares. Based on local socioeconomic and geographic conditions, the establishment of PDUs is the appropriate approach to leverage degraded pastureland restoration with cocoa-based AFS, while improving food security conditions with new income generation practices. In parallel to the PDUs implementation, The Nature Conservancy is working on a business plan to attract investment to the cocoa supply chain in SFX. 


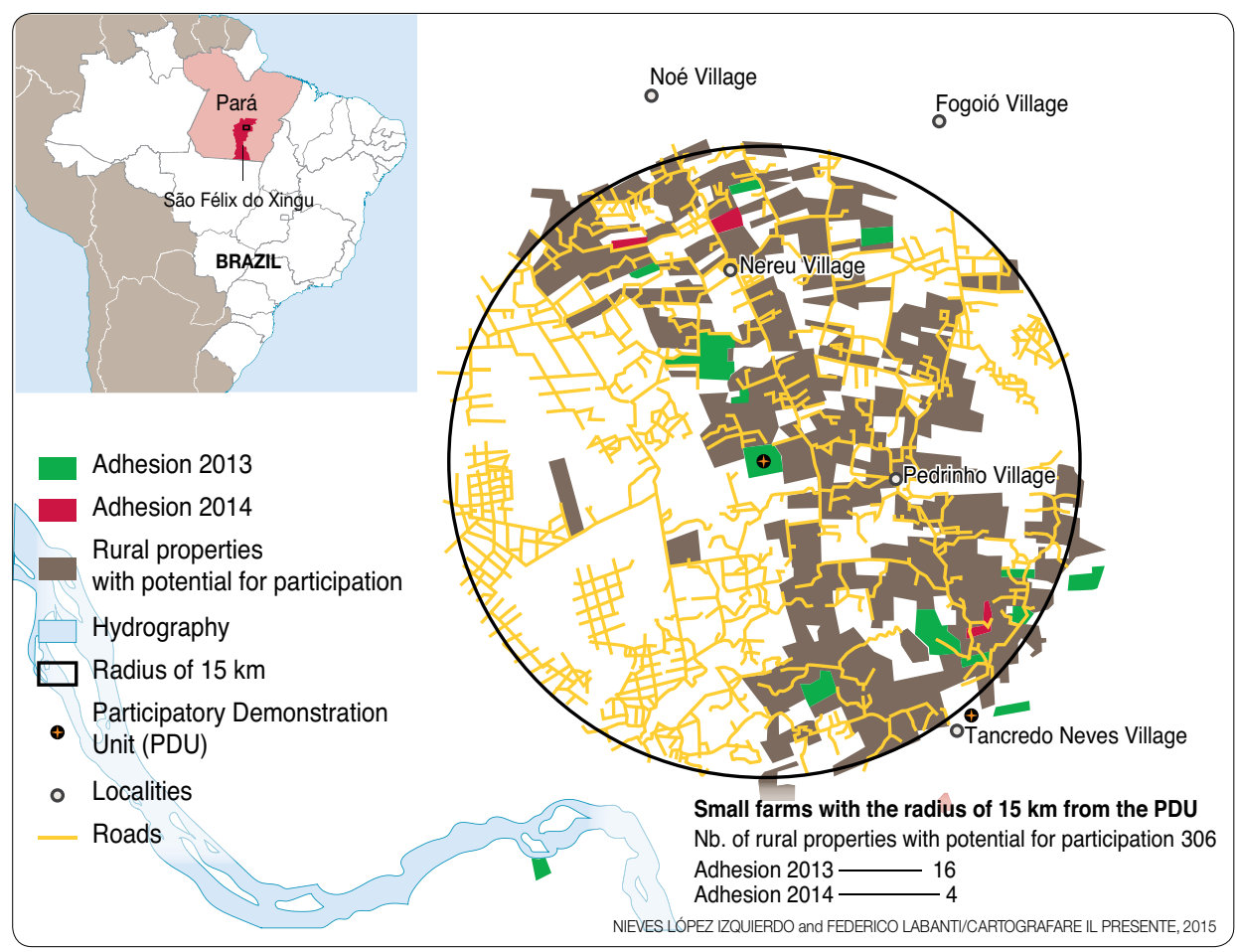

Figure 11.

Representation of

Ipê participative

demonstration unit 


\section{Lessons learned and recommendations}

From this initiative in SFX, the key lessons learned are:

- Productive paradigm shift: In an area where the dominant economic activity is cattle ranching, and where there is a pervasive distrust of innovative initiatives, convincing small farmers to implement AFS in degraded, over-grazed pastures is not an easy task. They will only adopt these innovations if they realize their economic potential.

- Starting small: It is important to motivate small farmers to initiate cocoa-based AFS models in small agricultural areas with family-based labour.

- Valuing small farmers' empirical knowledge: It is important to adopt a model of rural technical assistance that avoids pre-defined technological packages and that values small farmers' empirical knowledge. In general, the small farmers involved in the project have a long history of migration to different regions, and also have extensive knowledge about family-based agriculture in their own regions.

- A strategy for scaling up: The technical assistance model on an individual basis is unable to provide services to a large number of small famers. There are also barriers related to technical training and distance. The adoption of the PDU model represents an opportunity for scaling up while valuing small farmers' knowledge and promoting a sense of collectivism among neighbouring communities, as well as fostering forestry restoration principles and enhancing food security. Additionally, this model provides an alternative technical rural assistance approach for adoption by local, state and federal agencies working with family agriculture in general.

- An 'impact investment' approach: Building a solid business plan to bring investment resources to the cocoa supply chain will be essential to the expansion of the project and its environmental, social and economic impact.

Finding innovative and effective interventions, as in the case study presented here, that influence agricultural production practices is critical to improve environmental, climate, economic and social outcomes. Because cocoa is a global, high-demanded commodity with an established market chain and a potential for high economic return, we believe that 
this case study presents a promising opportunity for restoration while strengthening food security among small farmers in critical Amazon development frontiers today.

Despite a recent drop in deforestation and some favourable scenarios in the Amazon, there is still much uncertainty about controlling illegal deforestation in the long run. As the contribution of 'social deforestation' to the current overall deforestation rates in the region increases, it becomes more and more imperative to find sustainable productive alternatives for small farmers. This bears implications for public policies, which need to address key issues related to the dynamic of productive practices and promote new structural and sustainable economic bases in the region in order to effectively fight deforestation.

Finally, scaling up this case study will demand continued efforts in strengthening institutional partnerships, continued engagement of small farming families, and capacity-building of farmers and rural technical assistance agents. Given the current positive outcomes, and the potential for dissemination of cocoa-based AFS through PDUs by small farmers in the municipality, especially settlement projects, it is possible to scale up restoration of degraded pastureland with cocoa-based AFS and to effectively contribute to global restoration initiatives such as the Bonn Challenge and the New York Declaration on Forests. 


\section{Acknowledgements}

We thank Raimunda de Mello and Rodrigo Mauro Freire for their support with the project development and implementation, and Fábio Pereira de Oliveira for his support in the initial fieldwork. This work is fruit of a partnership between The Nature Conservancy, Cargill, São Félix do Xingu Municipal Bureau of Agriculture (SEMAGRI), the Alternative Cooperative of Small Rural and Urban Producers (CAPPRU) and the Ministry of Agriculture's Cocoa Research and Technical Extension Agency (CEPLAC), with funding from the Norwegian Agency for Development Cooperation and Cargill.

\section{References}

Barreto, P., Souza, J., Noguerón, R., Anderson, A. and Salomão, R. (2005). Pressão humana na floresta Amazônica Brasileira. Belém: WRI-Imazon.

Cassano, C.R., Schroth, G., Faria, D., Delabie, J.H.C. and Bede, L. (2009). 'Landscape and farm scale management to enhance biodiversity conservation in the cocoa producing region of southern Bahia, Brazil'. Biodiversity and Conservation 18:577-603.

Diário da União (2014). Available: (http://cidades.ibge.gov.br/xtras/temas.php?lang=\&codmun=150730\&idtema=130\&s earch=para|sao-felix-do-xingulestimativa-da-populacao-2014- [accessed 14 September 2015].

Dias-Filho, M.B., Davidson, E.A. and Carvalho, C.J.R. (2001). 'Linking biogeochemical cycles to cattle pasture management and sustainability in the Amazon Basin'. In: Mcclain, M.E., Victoria, R.L. and Richey, J.E. (eds). The biogeochemistry of the Amazon Basin, pp.84-105. New York: Oxford University Press.

Dias-Filho, M.B. (2014). Reclaiming the Brazilian Amazon: The restoration and management of pasture lands. Belém: Brazilian Agricultural Research Corporation (EMBRAPA) Eastern Amazon.

EMBRAPA and INPE (2014). Levantamento de Informações de Uso e Cobertura da Terra na Amazônia Legal - 2012. Available: http://www.inpe.br/cra/projetos_pesquisas/TerraClass_2012_26nov2014.pdf [accessed 14 September 2015].

Faminow, M.D. (1998). Cattle, Deforestation, and Development in the Amazon: An Economic, Agronomic, and Environmental Perspective. Wallingford, United Kingdom: CAB International.

Gomes, C.V.A., Bartels, W.L., Schmink, M., Duarte, A.P. and Arcos, H.D.S.S. (2008). 'Planejando Futuros Sustentáveis com Pequenos Produtores: Programa Proambiente Pólo Alto Acre'. In: Bensusan, N. and Armstrong, G. (eds). O Manejo da Paisagem e a Paisagem do Manejo, pp.121-156. Brasília: IIEB.

Gomes, C.V.A., Perz, S.G. and Vadjunec, J.M. (2012). 'Convergence and contrasts in the adoption of cattle ranching: Comparisons of smallholder agriculturalists and forest extractivists in the Amazon'. Journal of Latin American Geography $11(1): 99-120$.

INPE (2015). PRODES Digital. Instituto Nacional de Pesquisas Espaciais, São José dos Campos. Available: http://www. dpi.inpe.br/prodesdigital/prodes.php [accessed 14 September 2015].

Ludewigs, T., D’Antona, A.D., Brondizio, E.S. and Hetrick, S. (2009). 'Agrarian Structure and Land-cover Change Along the Lifespan of Three Colonization Areas in the Brazilian Amazon'. World Development 37(8):1348-1359. 
Nepstad, D., Stickler, C.M. and Almeida, O.T. 2006. 'Globalization of the Amazon soy and beef industries: Opportunities for conservation'. Conservation Biology 20:1595-1603.

Pacheco, P. (2009). 'Agrarian Reform in the Brazilian Amazon: Its Implications for Land Distribution and Deforestation'. World Development 37(8):1337-1347.

Paraense, V.C., Mendes, F.A.T. and Freitas, A.D.D. (2013). Avaliação Econômica de Sistemas Agroflorestais de Cacau e Mogno na Transamazônica: um Estudo de Caso. Enciclopédia Biosfera. Available: http://www.conhecer.org.br/ enciclop/2013a/agrarias/avaliacao\%20economica\%20de\%20sistemas.pdf

Perz, S.G. (2002). 'The Changing Social Contexts of Deforestation in the Brazilian Amazon'. Social Sciences Quarterly 83:35-52.

Sanguino, A.C., Santana, A.C., Homma, A.K.O., Barros, P.L.C., Kato, O.K. and Amin, M.M.G.H. (2007). 'Economic Evaluation of Agroforestry Systems to Minimize Deforestation in the Amazon Basin of Brazil'. Rev. Ciência. Agrária. 47:71-88.

Schmink, M. and Wood, C. (1992). Contested Frontiers in Amazonia. New York: Columbia University Press.

Schmink, M., Hoelle, J., Gomes, C.V.A., Thaler, G. and Wood, C.H. (2014). The "New Amazonian Frontier" and Environmental Governance in São Felix do Xingu, Brazil. Research Report. Palo Alto, California: Gordon and Betty Moore Foundation.

Schroth, G., Harvey, C.A. and Vincent, G. (2004). 'Complex agroforests - their structure, diversity, and potential role in landscape conservation'. In: Schroth, G., Fonseca, G.A.B., Harvey, C.A., Gascon, C., Vasconcelos, H.L. and Izac, A.M.N. (eds). Agroforestry and Biodiversity Conservation in Tropical Landscapes, pp.227-260. Washington, DC: Island Press.

Schroth, G. and Harvey, C.A. (2007). 'Biodiversity conservation in cocoa production landscapes: An overview'. Biodiversity and Conservation 16:2237-2244.

Schroth, G., Garcia, E., Griscom, B.W., Teixeira, W.G. and Barros, L.B. (2015). 'Commodity production as restoration driver in the Brazilian Amazon? Pasture re-agro-forestation with cocoa (Theobroma cacao) in southern Pará'. Sustainability Science. Available: http://link.springer.com/article/10.1007/s11625-015-0330-8

Smeraldi, R. and May, P. 2008. O Reino do Gado: Uma Nova Fase na Pecuarização da Amazônia Brasileira. São Paulo: Amigos da Terra-Amazônia Brasileira.

Tourrand, J. and Veiga, J.B. (eds) (2003). Viabilidade de sistemas agropecuários na agricultura familiar da Amazônia, pp.103-117. Belém: Embrapa Amazônia Oriental.

Tscharntke, T., Milder, J., Schroth, G., Clough, Y., DeClerck, F., Waldron, A. and Ghazoul, J. (2011). 'Conserving biodiversity through certification of tropical agroforestry crops at local and landscape scales'. Conservation Letters 8:14-23.

Waldron, A., Justicia, R. and Sanchez, M. (2012). Conservation through chocolate: A win-win for biodiversity and farmers in Ecuador's lowland tropics. Conservation Letters 5:213-221.

Walker, R., Moran, E. and Anselin, L. (2000). 'Deforestation and Cattle Ranching in the Brazilian Amazon: External Capital and Household Processes'. World Development 28:683-699.

Wood, G.A.R. and Lass, R.A. (2001). Cocoa, fourth edition. Oxford, United Kingdom: Blackwell Scientific. 


\section{Agroforesty system kuxur rum enhancing food and nutritional security in Guatemala}

Jose Artemio Ramirez Maradiaga

Food and Agriculture Organization of the United Nations, Guatemala Corresponding authors: Alberto Bigi, Baltazar Moscoso Caminade 


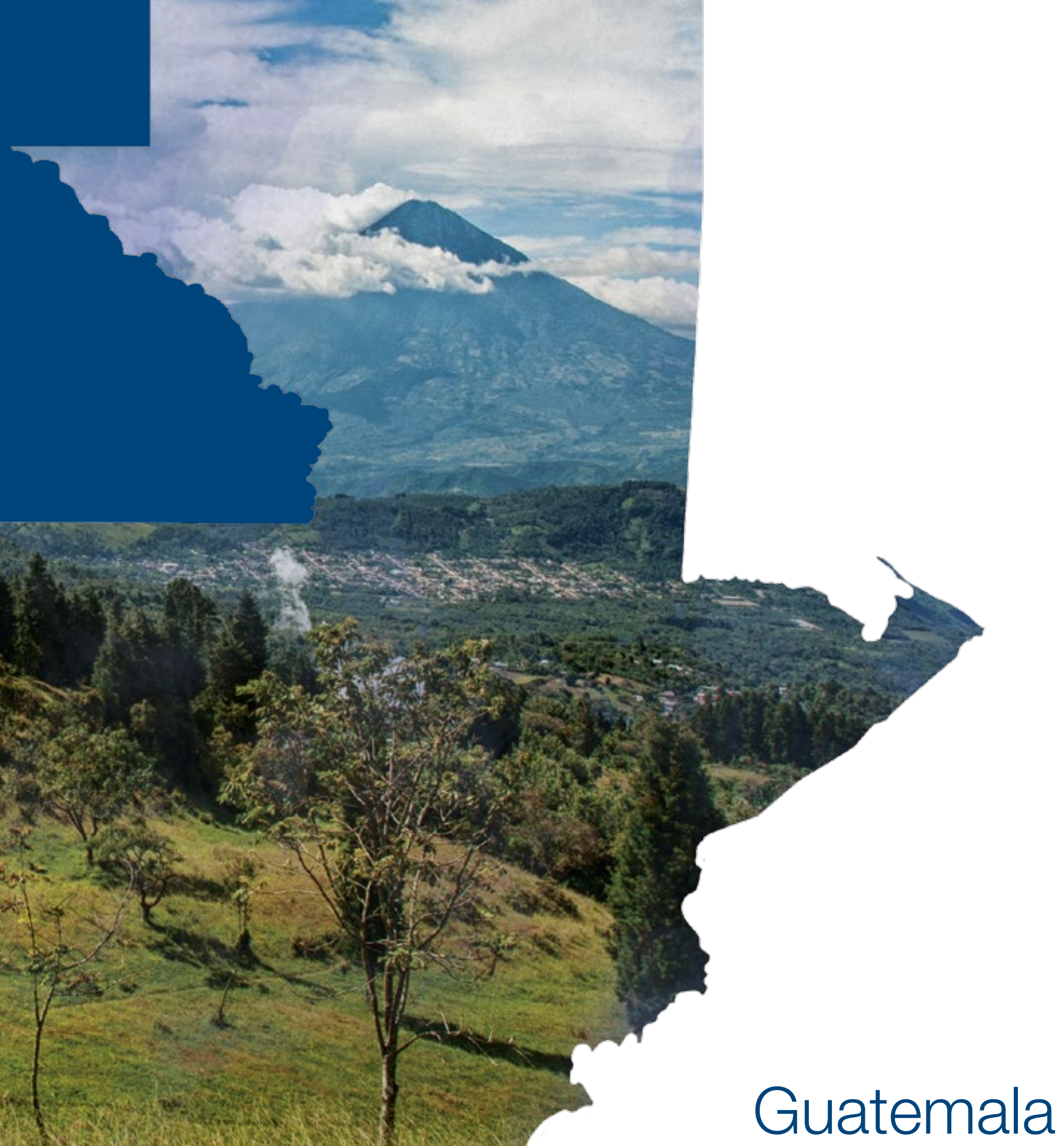




\section{Introduction}

During the 10th meeting of the Conference of the Parties (COP) on biological diversity, Guatemala was considered a 'megadiverse country' in terms of cultural and biological diversity (UNEP, 2010). This is manifested by the plurality of ethnic groups, languages, religious beliefs, arts, music, social structures, land management and agricultural practices established in its territory (CONAP, 2013). It is in the rural areas where this diversity can be best appreciated and where 51.5\% of the population live (INE, 2011).

Despite such richness of cultural and biological diversity, socioeconomic indicators in rural areas position Guatemala among the countries with the lowest human development in Central America (UNDP, 2015).

According to the National Statistics Institute (INE, 2013), Guatemala's rural population is among the poorest in Central America. More than $70 \%$ of the population suffering food insecurity live in rural areas; $50.9 \%$ were identified as indigenous people from Maya, Garifuna and Xinca ethnic groups, and around 1.3 million households depend mainly on

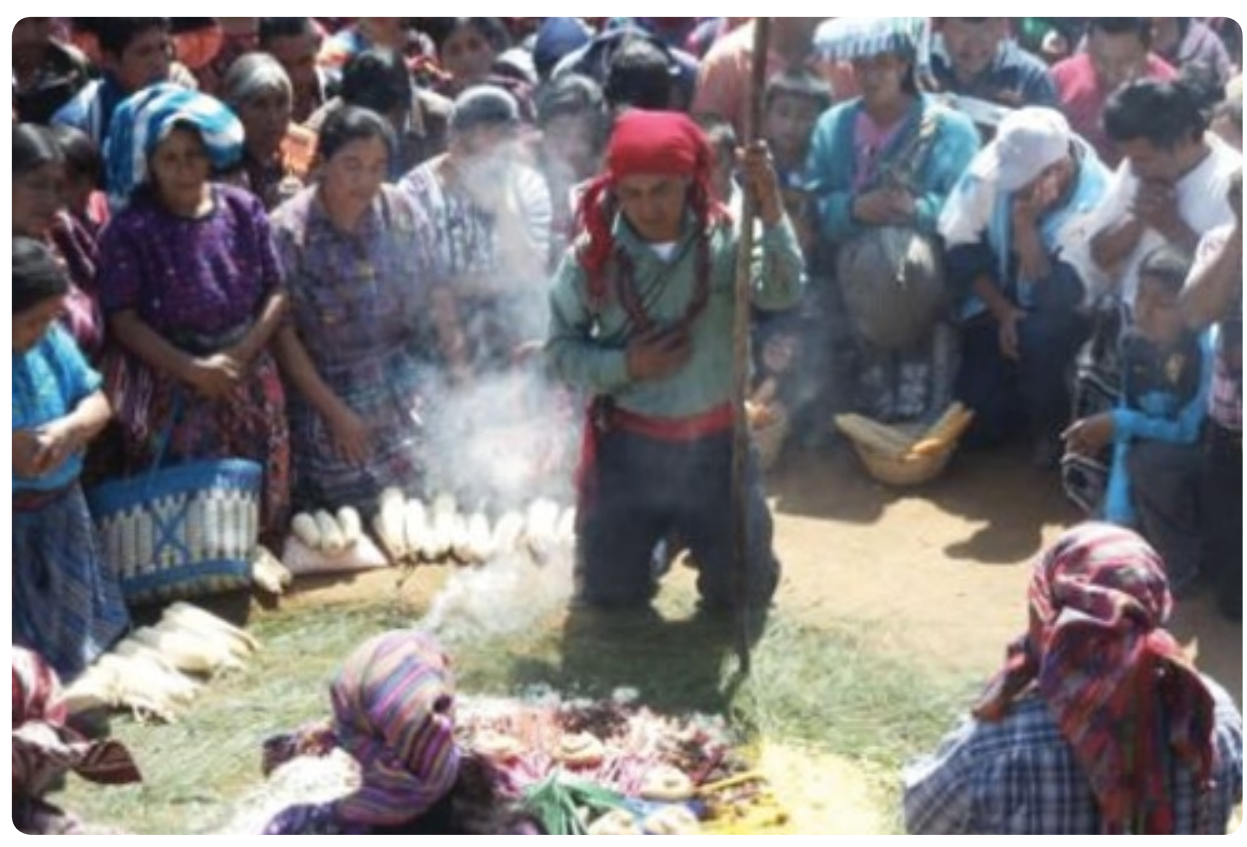

Figure 1.

Blessing beans and maize seeds for the new production cycle (Sololá, Guatemala) (photo credit: $\odot F A O / J o s e ́$ Ramirez Maradiaga) 


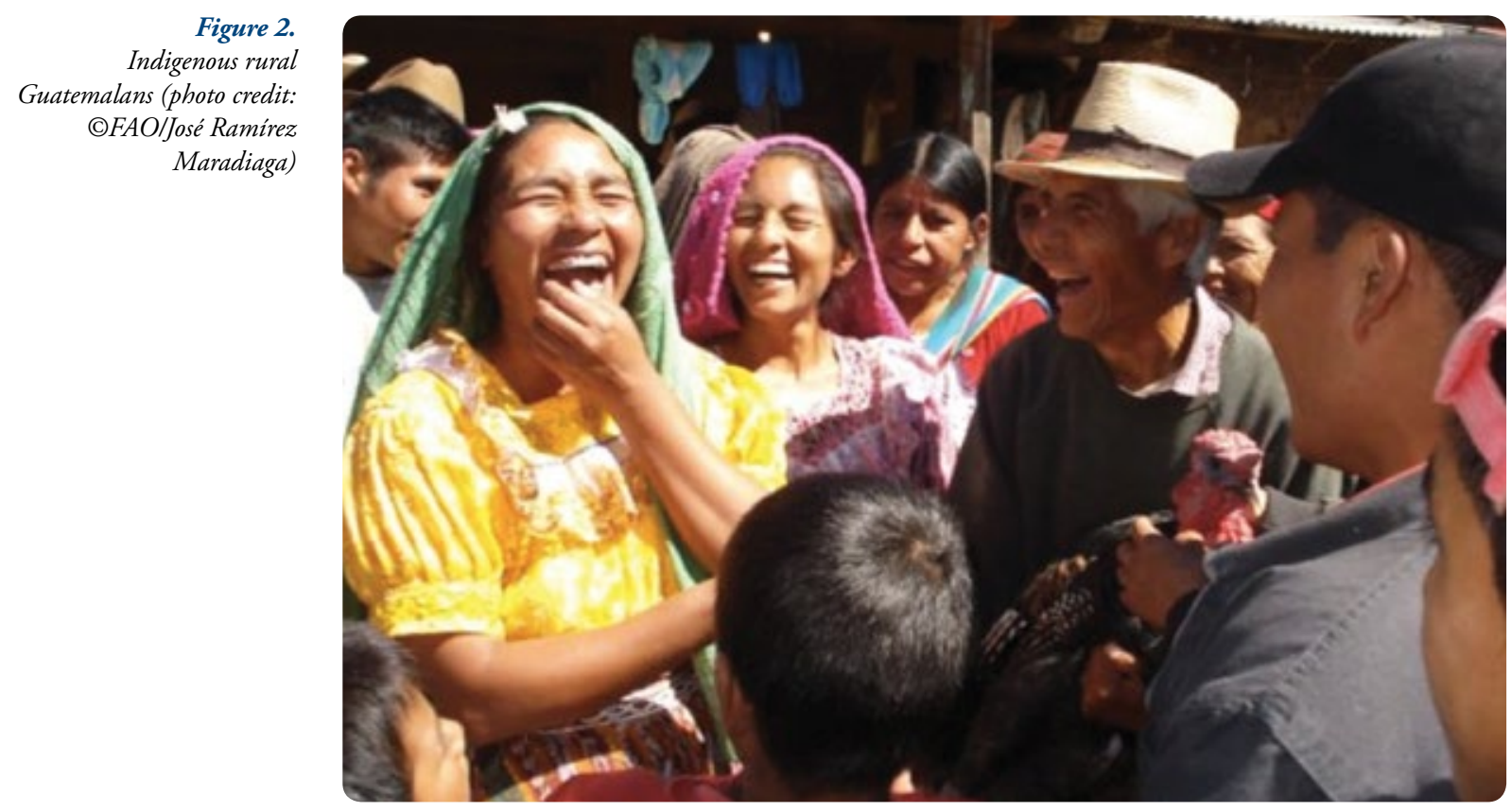

family farming. These households have insufficient access to natural resources, agricultural inputs, training and technology. Under the pressure of population growth of the 20th century, natural, physical and financial assets have continued to decrease along with a subsequent increase in land tenure fragmentation (FAO, 2014a).

It is estimated that $70 \%$ of the land of the country is used for agricultural and forestry activities, including family farming and agribusiness. Family farming is experiencing an ongoing process of farm size reduction and an increasing number of owners, particularly in farms smaller than 7 hectares. Approximately 164,097 agricultural households do not own land, but practise some degree of small-scale subsistence family farming (MAGA, 2012).

Family farms are characterized by a diverse range of assets such as: traditional knowledge about genetic resources and management techniques; capacity adaptation; partnership, family and community networks; rights over land, forests and natural resources.

Guatemala is experiencing high levels of food insecurity and malnutrition as a result of irregularities in rainfall, recurrent natural disasters, environmental degradation, inadequate agricultural infrastructure and poor agricultural policies, among other factors. Guatemala currently has one of the highest rates of chronic malnutrition in the world, which has led to a rapid increase in mortality, especially among children under the age of five (SESAN, 2012). 


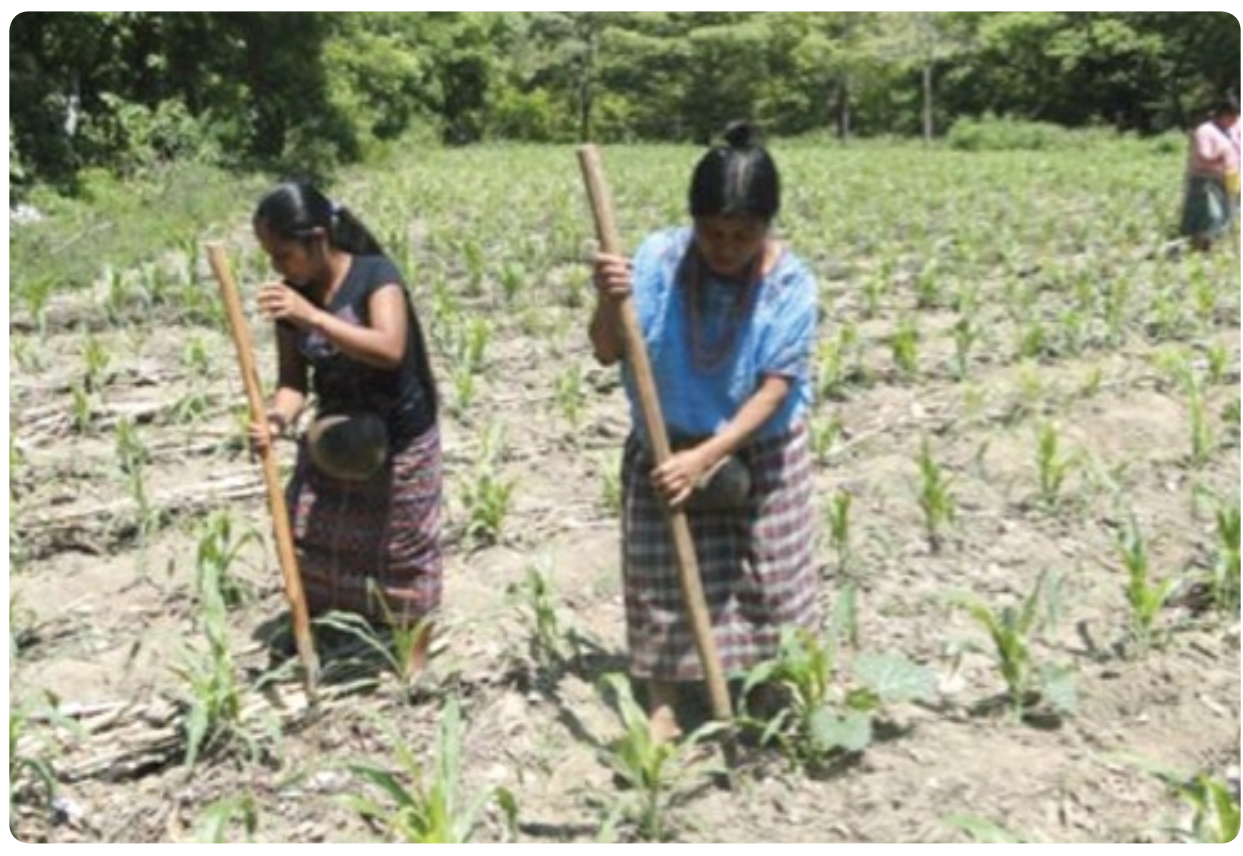

In recent years, Guatemala has been severely affected by abnormal rainfall patterns and weather phenomena, which have caused high losses of staple crops (60-100\%) in family farming production, especially in the central and eastern territories (FAO, 2014b).

Family farmers depend on natural resources, but their practices are often the main cause of the degradation. Land and water are experiencing the highest rates of degradation and deterioration in Latin America. Most of these losses were caused by fuelwood collection, unsustainable agricultural practices and land expansion for intensive agriculture use (USAID, 2011).
Figure 3.

Family farmers labouring (Baja Verapaz, Guatemala) (photo credit: (CFAO/José Ramirez Maradiaga) 


\section{Forest landscapes and the dry corridor}

According to IUCN and the National Council of Protected Areas (CONAP, 2013), the country has one of the most extensive and diverse forest systems in Central America: 14 ecoregions ranging from mangrove forest in both ocean littorals, dry forests and scrublands in the eastern highlands, subtropical and tropical rainforests, wetlands, cloud forests, mixed forests and pine forests in the highlands. Over one third of Guatemala (36.3\% $\left.39,380 \mathrm{~km}^{2}\right)$ is forested. About half of the forests $\left(49.7 \%-19,570 \mathrm{~km}^{2}\right)$ are classified as primary forest, which is considered the most biodiverse forest type. Some of Guatemala's protected areas are the largest in Central America (123 protected areas - more than 29\% of the territory) and are recognized as World Heritage sites.

Figure 4.

Forest landscape in the highlands of Guatemala (Chiquimula, Guatemala) (photo credit: (CFAO/José

Ramírez Maradiaga)

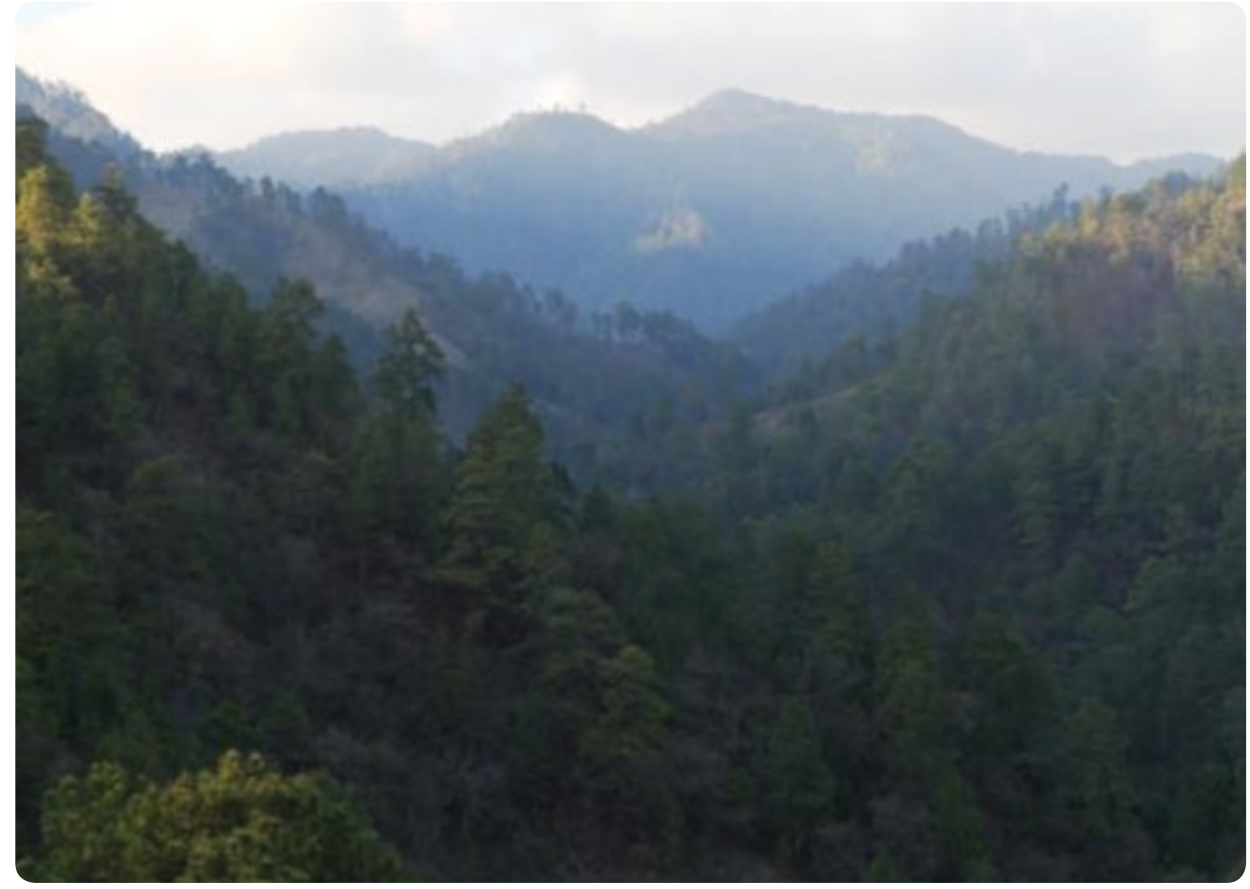




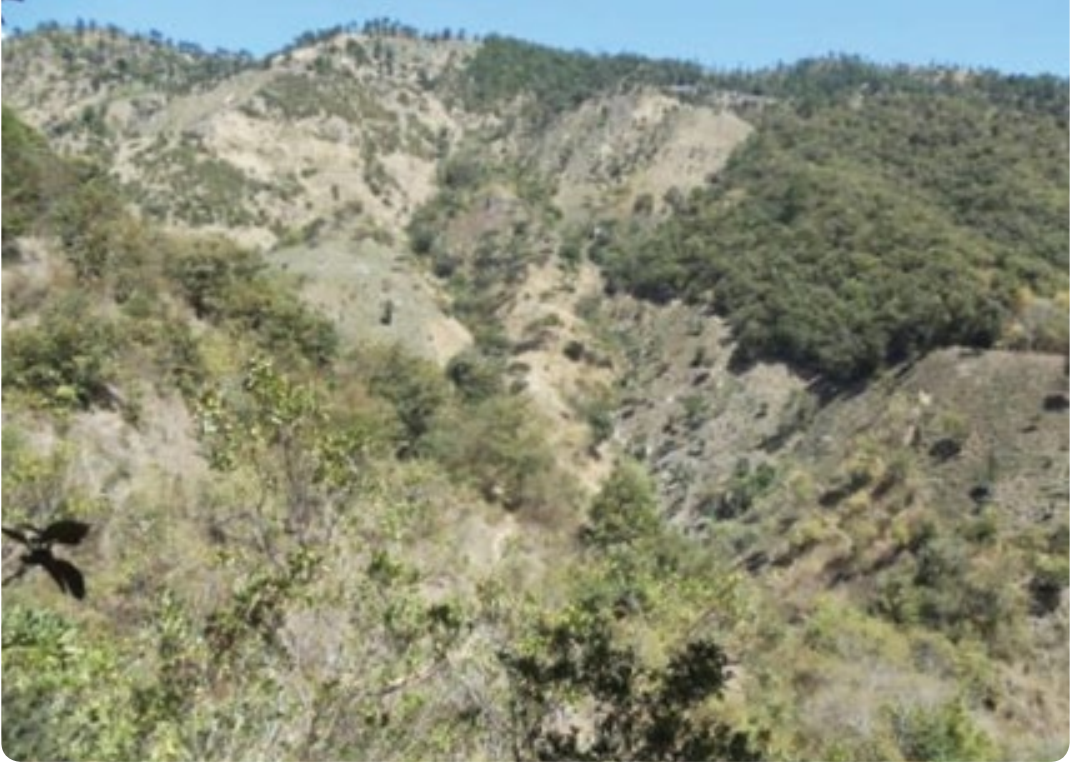

Forest coverage is falling at one of the highest rates in Latin America. Official figures show that 80,000-95,000 hectares are deforested each year, which represent $1 \%$ of the country's forests lost per year (INAB, 2012; CONAP, 2013).

One of the main reasons for deforestation is the consumption of firewood - nationally $15,771,200$ tonnes/year. An analysis of the supply/demand indicates that around $36 \%$ of the consumption $(5,725,300$ tonnes/year) comes from natural forests in unregulated processes (INAB, 2012).

The vegetation cover of the land has become inadequate to retain rainfall, humidity and soil. When rains fall, vast amounts of fertile soil are washed away via landslides threatening crops, infrastructure and lives. Delays in the start of the rainy season and irregularities in rainfall are becoming stronger and more frequent as a result of climate change, which is especially severe in the dry corridor.

The 'dry corridor', located in eastern Guatemala, is a poor, degraded and sloped territory (Figures 5, 6 and 7), with altitudes ranging from $300 \mathrm{~m}$ to 1,800 $\mathrm{m}$ above the sea level. The corridor area is comprised of six provinces including Chiquimula, Zacapa, Jutiapa, Jalapa, El Progreso and Baja Verapaz. The average annual rainfall ranges from 500 $\mathrm{mm}$ to $1200 \mathrm{~mm}$, which is distributed erratically between the months of May and October. The most important varieties of staple crops in Guatemala (and in the dry corridor) are white corn and black bean. Table 1 shows the agricultural calendar of the main staple crops (corn, sorghum and beans) and the main hazards according to season.

Figure 5.

(left)

Forest landscape in the dry corridor of Guatemala (Chiquimula, Guatemala) (photo credit: (CFAO/José Ramirez Maradiaga)

Figure 6.

(right)

Forest landscape in the dry corridor of Guatemala (Chiquimula, Guatemala) (photo credit: (CFAO/José Ramirez Maradiaga) 
Table 1.

Agricultural calendar and recurrent risks affecting food security stability

\begin{tabular}{|c|c|c|c|c|c|c|c|}
\hline Month & Jan & Feb Mar & Apr & May Jun & Jul Aug & Sep Oct & Nov Dec \\
\hline Seasons & & Dry & & Rainy & Dry $^{*}$ & Rainy & Dry \\
\hline $\begin{array}{l}\text { Sorghum, } \\
\text { corn and } \\
\text { bean }\end{array}$ & & & & Sowing & $\begin{array}{l}\text { Harvesting } \\
\text { (beans and } \\
\text { corns) }\end{array}$ & & $\begin{array}{l}\text { Harvesting } \\
\text { (sorghum) }\end{array}$ \\
\hline $\begin{array}{l}\text { Corn and } \\
\text { bean }\end{array}$ & & & & & Sowing & & Harvesting \\
\hline
\end{tabular}

\begin{tabular}{l}
\hline \multicolumn{1}{c}{ Main hazards } \\
\hline $\begin{array}{l}\text { Agricultural } \\
\text { drought }\end{array}$ \\
\hline Rain \\
excess and \\
hurricanes \\
(erosion, \\
landslides) \\
\hline High food \\
prices \\
\hline Wild fires \\
\hline
\end{tabular}

Source: Compiled by the author.

Notes: * This short dry season falling between the rainy seasons is called canicula and its variable duration is very often the cause of harvest losses.

The topography of the land is sloping and susceptible to erosion, especially if agricultural production is not implemented via appropriate agricultural practices. Many families grow crops on land less than half the size of a soccer field. One consequence of these trends is that the soil is losing organic matter, and it cannot hold as much rainwater as previously. At the same time, the risk of floods, mudslides and landslides during the rainy season has risen, especially during intense storms such as hurricane Stan in 2005 and tropical storm Agatha in 2010. Climate change is expected to worsen the situation in all Central American regions, especially in dry areas and mountainous regions such as the Guatemala dry corridor.

Poverty in the area has been aggravated by limited access to land, monoculture cropping systems, inappropriate agricultural practices, lack of irrigation systems and lack of basic production assets. This has resulted in deteriorated soils and a downward trend in productivity. Food reserves generally last for six months. In this context, occasional labour provides the income critical to the livelihoods of most families. These families adjust 


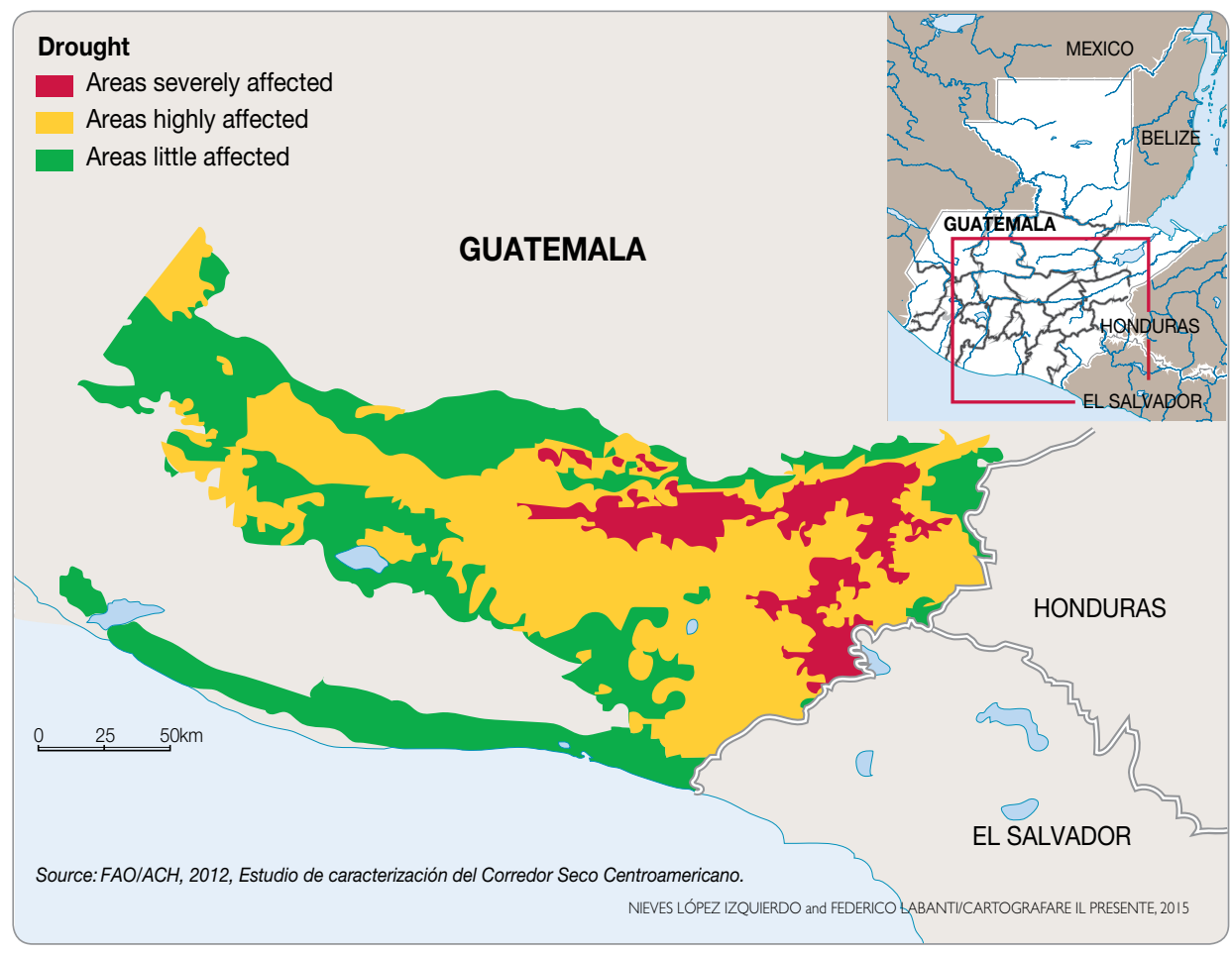

Source: FAO/ACH (2012). Estudio de caracterización del Corredor Seco Centroamericano.

Notes: Red = areas severely affected by drought; yellow = areas highly affected; green = areas little affected.

their daily diet according to their level of income. If the demand for agricultural labour is reduced and/or crops are not expected, the poor adapt their diet, reducing the number of meals, which results in increasing chronic malnutrition. One of the strategies families adopt to generate the income necessary for subsistence is migration, which causes family disintegration.

The dietary intake of the people in the area mainly depends on the family farm production (of beans and corn), which has been declining as a result of natural resources' degradation and climate change. The lack of land, forces farmers to establish subsistence corn plots on the sloping, stony, fragile and dry hillsides. As the plots have to be rotated every few years because of soil degradation, farmers need to expand their agricultural frontier causing major deforestation and degradation of the watershed.

The livelihoods of the dry corridor are basic grain production and selling of part-time, casual or seasonal labour. Coffee, especially in the highest part of the area, as well as small amounts of sorghum or millet associated with corn and beans are also grown. Poorer families
Figure 7.

The dry corridor of

Guatemala 
Identifying the sustainable development alternatives has been recognized as a priority by the government and the international community since 2000 - which have been supporting the communities through humanitarian and development aid. However, these emergency-response initiatives have been insufficient to sustain the livelihoods of family farmers in the long term.

The situation outlined, indicates the need to come up with innovative, objective and validated solutions to restore the provision of goods and services from forests and other landscapes ensuring agricultural production and food security across this region (IUCN, 2014)

One of these innovative solutions could be the Global Partnership on Forest and Landscape Restoration (GPFLR) approach. This approach emphasises that landscapes can have multiple functions, as they provide a variety of services to society, such as biodiversity, food, water, shelter, livelihood, economic growth and human well-being. All these services are interlinked; so if the agricultural area in a landscape expands, it will have repercussions for the area covered by forests. Working on this approach could be an opportunity for countries such as Guatemala to face the new global challenges embracing climate change adaptation and mitigation in an integrated development agenda.

The approach of forest landscape restoration (FLR) is supported by the Bonn Challenge, as a new global commitment, which aims to restore ecological integrity and to improve human well-being through multifunctional landscapes. The Bonn Challenge is a global agreement to restore 150 million hectares of the world's deforested and degraded lands by 2020. It was launched by world leaders in Bonn, Germany, September 2011.

\section{Forest landscape restoration and kuxur rum dissemination}

In 2000, in response to the high levels of hunger and malnutrition in the dry corridor, $\mathrm{FAO}$, in coordination with the Ministry of Agriculture of Guatemala and local authorities, launched a special food security programme located in the province of Chiquimula, sponsored by the Spanish Agency for International Development Cooperation (AECID). This province forms part of the dry corridor area, which suffers from recurrent drought cycles and food shortages. The scope of the project was to identify good practices in reducing food insecurity, with an emphasis on gender and ancestral knowledge, to create linkages between family farmers and national policies; and to establish an institutional framework aimed at combatting hunger and malnutrition.

The methodology to identify and promote good agricultural practice was through the strengthening of local extension services and the use of the participatory method of Farmer Field School (FFS) (Van den Berg, 2004). 
Table 2.

Differences between conventional extension methods and the FFS approach

\begin{tabular}{|c|c|c|}
\hline Parameter & Farmer Field School & Conventional extension \\
\hline Learning method & $\begin{array}{l}\text { By doing, experimenting, } \\
\text { participating, discovering }\end{array}$ & By listening and doing \\
\hline Training venue & Demonstration plot & Training room, field \\
\hline Duration & $\begin{array}{l}\text { Complete study } \\
\text { (season-long cycle) }\end{array}$ & One or two sessions \\
\hline Role of the extension agent & Expert facilitator & Expert promoter \\
\hline Role of the farmer & Decision maker and promoter & Listener \\
\hline Qualification to participate & Non-discriminatory & Need to be able to write and read \\
\hline Programme planning & Elaborated by farmers & Office work \\
\hline $\begin{array}{l}\text { Evaluation and adoption } \\
\text { processes }\end{array}$ & $\begin{array}{l}\text { Evaluation by farmers, adoption is the } \\
\text { choice of the farmer }\end{array}$ & $\begin{array}{l}\text { Evaluation by extension, } \\
\text { usually adoption is a process of } \\
\text { persuasion }\end{array}$ \\
\hline
\end{tabular}

Source: Data from Van den Berg, 2004.

The FFS is a group, peer-to-peer, learning extension method based on principles of adult education. It helps farmers learn from each other by improving their capacity to make decisions and innovate on their own farms and within their own communities. It is a participatory approach to extension, whereby farmers are given opportunities to make choices in the methods of production through empirical and practical discoveries on their own or their neighbours' farms.

A FFS is composed of groups of farmers who meet regularly during the course of the growing season to experiment with new production options. Typically FFS groups have 15-30 farmers. After the training period, farmers continue meeting and sharing information without input from their extension officers. The FFS methodology aims to increase the capacity of groups of farmers to test new technologies on their own, to assess results and to determine the value of the results for their own particular circumstances. Field activities and innovation evaluation are promoted through the free distribution of some of the necessary agricultural inputs and tools. The training methodology of FFS is based on learning by doing through discovery, comparison and non-hierarchical relationships among the learners and trainers. It is also carried out almost entirely in the field.

Through FFS, FAO and farmers identified the major sustainable agricultural practices aimed at building resilience of households and livelihoods, and preserving natural resources based on the local available resources (Table 3). 
2 Use of improved quality seeds

3 Use of adequate quantity of seeds and spacing for sowing

4 Establishment of contour lines and slope management approaches

$5 \quad$ Minimum tillage

$6 \quad$ Organic mulching and crop residues management

$7 \quad$ Crop rotation and diversification

8 Use of windbreaks

$9 \quad$ Terracing

11 Vegetables from home gardens

12 Integration of tree crop species in the farm management system - agroforestry system

Source: Compiled by the author, based on the reports and records of the Food Security Special Programme (FAO, 2006).

During FFS sessions, the FAO technical team realized that an ancient and sustainable practice from the Ch'orti' indigenous people already existed: the planting of dispersed trees of Gliricidia sepium and mixing them with annual crops within the plot.

The main objective of this practice was to provide protection to soil and crops from the erosive effect of rain and preserve soil moisture during the drought period, through the shade of the trees reducing evapotranspiration and the addition of organic matter through the leaves of the trees that naturally fall on the plot.

Gliricidia sepium is a medium-sized leguminous tree occurring in abundance throughout its native range in Mesoamerica. Domestication of Gliricidia has been in progress for several millennia and the multitude of indigenous common names from Mayan and Quiche peoples (Pertchik \& Pertchik, 1951) reveals the importance of this species to early occupants of the region. Spanish colonists adapted the local vernacular in naming the species madre de cacao (mother of cocoa) to describe its use as a cocoa shade tree. Despite the widespread present occurrence of $G$. sepium in cultivation throughout Central American countries and Mexico, it is thought to be native only in the seasonally dry forest (Hughes, 1987). 
Figure 10.

(left)

Gliricidia sepium multipurpose forage tree legume (agroforestry system in dry corridor (Camotan, Chiquimula, Guatemala) (photo credit: (CFAO/José Ramirez Maradiaga)

Figure 11. (right) Agroforestry system kuxur rum (San Juan Ermita, Chiquimula, Guatemala) (photo credit: (CFAO/José Ramírez Maradiaga)
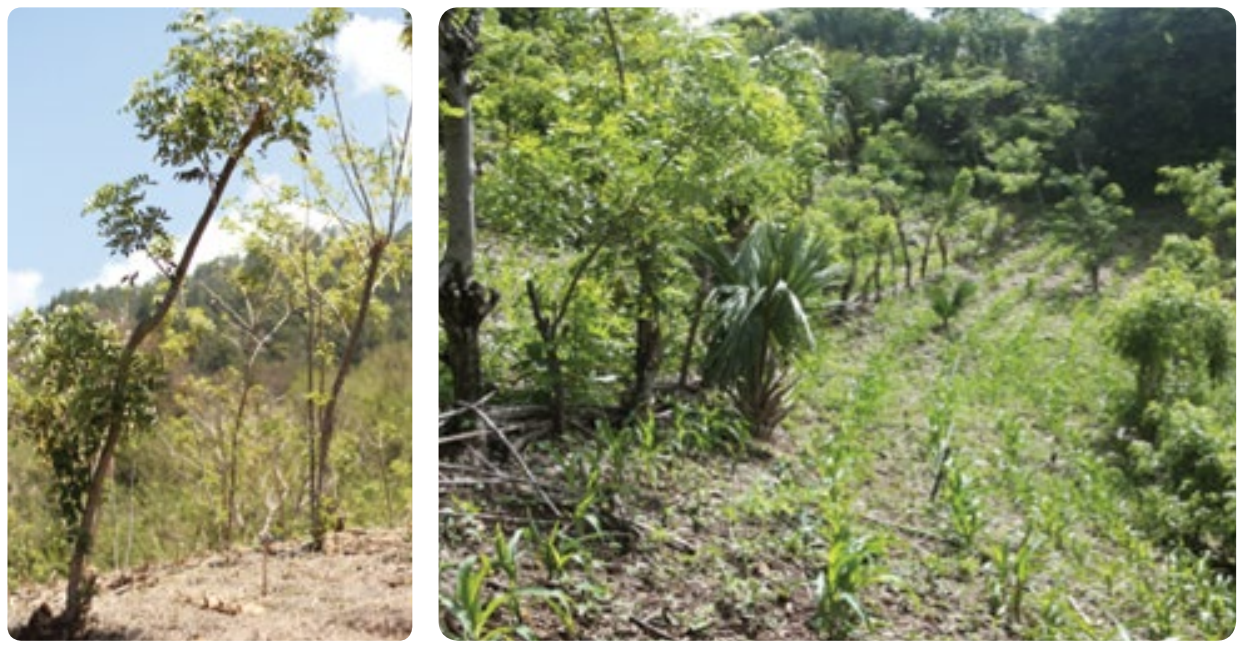

Few non-industrial tree species embody the concept of a multipurpose tree better than G. sepium. Throughout both its native and exotic ranges it is used to supply tree products such as fuelwood, construction poles, crop supports, green manure, fodder and bee forage. In addition, it is used in living fences, to stabilize soils and prevent erosion, to shade plantation crops, as an ornamental and in traditional medicine (Simons \& Stewart, 1994).

FAO recognized the traditional practice potential and promoted an increasing number of trees of Gliricidia sepium per plot with an adequate distance complementing with other technical practices for farm and plot highlighted in Table 3. This practice was developed by participative methodology to take advantage of local indigenous knowledge, for example, one of the major recommendations from farmers was to consider the influence of the lunar phases in the planting of seeds and cuttings.

The interaction of the local indigenous people and technical professionals from the programme created an alternative technology based on ancient knowledge, making use of multipurpose native trees from the dry forest. The local farmers named the practice kuxur rum - meaning 'my humid land' in Ch'orti'.

A pilot plot to validate the technology was carried out from 2000 to 2001 and started with the implementation of soil and water conservation practices before the planting of Gliricidia sepium. The trees were planted at an average distance of $6 \mathrm{~m}$ between rows with spacing $1 \mathrm{~m}$ apart in rows. As the trees were growing, the branches were pruned to provide the adequate quantity of sun irradiation to crops and left to compost on the soil.

Once the concept of kuxur rum was defined, demonstration plots were selected to 


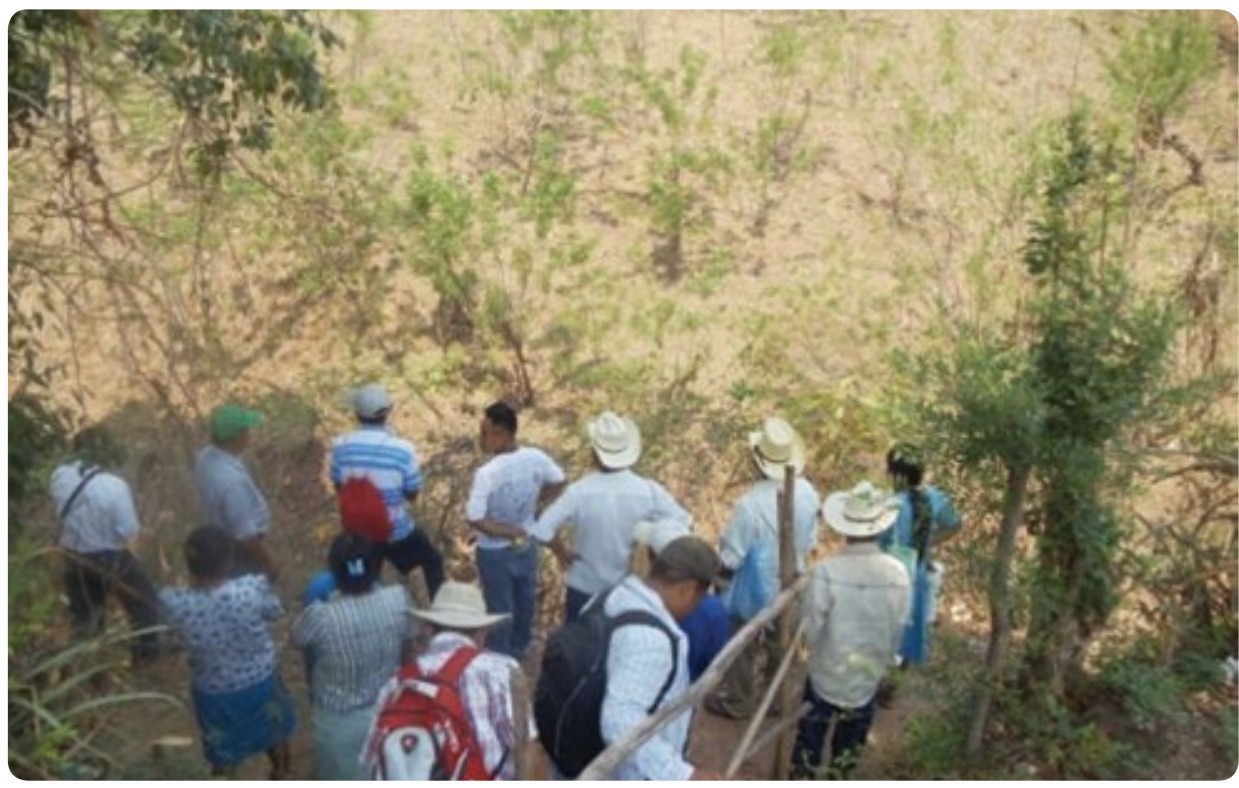

implement the practice and 25 farmers were trained as promoters to spread the technique in the province. During the period 2001 to 2003 around 190 families replicated the kuxur rum practice on an average of $0.17 \mathrm{ha} / \mathrm{family}$.

In 2004 the practice was scaled up to the other provinces in the dry corridor, including Chiquimula, Zacapa, El Progreso, Jutiapa y Jalapa, with a total of 25 municipalities and 154 communities. Partnerships and alliances were created as shown in Table 4.

\begin{tabular}{ll}
\hline \multirow{3}{*}{ Sector } & Name \\
\hline \multirow{2}{*}{ Public } & Agriculture Ministry (MAGA) \\
\cline { 2 - 2 } & Institute of Science and Technology for Agriculture (ICTA) \\
\cline { 2 - 2 } & Food and Nutritional Secretariat (SESAN) \\
\hline Private & Mayors of the municipalities \\
\hline University & Technical Institute for Training and Productivity (INTECAP) \\
\hline Cooperation (NGOs) & Action Contre la Faim or ACF International (ACH) \\
\cline { 2 - 2 } & Caritas International \\
\hline Civil society & Community-based organizations and community promoters' networks \\
\hline
\end{tabular}

Source: Compiled by author, based on the reports and records of the Food Security Special Programme (FAO, 2006).
Figure 12.

Field day with community promoters (San Juan Ermita, Chiquimula) (photo credit: CFAO/José Ramírez Maradiaga)

Table 4.

Partnerships and alliances 
The first step towards promoting the implementation of kuxur rum at a larger scale was to increase the awareness and knowledge of stakeholders about the practice. A communication strategy was executed using various channels - radio, television, newspaper and magazines - adjusting the message as appropriate. This enabled the vision to be shared with all stakeholders encouraging them to consider this practice as an alternative to conventional agriculture in the context of adapting to climate change.

The rural extension services provided training and technical assistance, and facilitated inputs such as fertilizers, agricultural tools and seeds to motivate farmers. The farmers engaged in the project made a commitment to collect cuttings or seeds and to invest their entire labour force for the establishment of the kuxur rum agroforestry system over a minimum of 0.17 ha per family.

At field level, the dissemination of this innovation was boosted by the 'farmer to farmer' methodology, involving 359 community promoters who supported and served as examples for the neighbours.

Table 5.

Timeline for scaling up the kuxur rum agroforestry system

\begin{tabular}{cccc}
\hline Year & $\begin{array}{c}\text { Number of families implementing kuxur } \\
\text { rum on their farm }\end{array}$ & Men & Women \\
\hline 2002 & 114 & 73 & 41 \\
\hline 2003 & 176 & 146 & 30 \\
\hline 2004 & 1,065 & 1,033 & 32 \\
\hline 2005 & 2,137 & 2,095 & 232 \\
\hline 2006 & 4,137 & 3,124 & 1,013 \\
\hline Total & $\mathbf{7 , 6 2 9}$ & $\mathbf{6 , 5 7 1}$ & $\mathbf{1 , 3 4 8}$ \\
\hline
\end{tabular}

Source: Compiled by the author, based on the reports and records of the Food Security Special Programme (FAO, 2006).

After five years' implementation the number of families engaged in kuxur rum numbered 7,000 with an estimated 1,100 hectares involved, spread over five provinces of the dry corridor; and $17 \%$ of households were headed by women (Table 5).

As shown in Table 6, one of the biggest challenges was to integrate the views and goals of all stakeholders - government, communities, the educational institutes, international agencies - creating synergies that allowed alignment of strategies and goals mainly by supporting networking, coordination, dialogue and harmonization among the existing programmes and initiatives aimed to enhance the food security. 


\begin{tabular}{cccc}
\hline Target & Territory space & Time/period & Outcome \\
Families & Plots/field schools & Short term & $\begin{array}{c}\text { Families improve their } \\
\text { livelihoods and food } \\
\text { security }\end{array}$ \\
\hline Communities & Micro-watershed & Short and medium term & $\begin{array}{c}\text { Build resilience and social } \\
\text { cohesion }\end{array}$ \\
\hline Municipalities & Sub-watershed & Medium and long term & $\begin{array}{c}\text { Integrate the stakeholders } \\
\text { from all sectors }\end{array}$ \\
\hline Departments & Watershed & Long term & Watershed-based planning \\
approach
\end{tabular}

Table 6.

Outcomes at different levels of interventions

Source: Reports and records of the Food Security Special Programme (FAO, 2006).

An analysis of this approach in the municipalities of Rabinal and Santa Cruz El Chol (Baja Verapaz Department) in further FAO projects (2009-2014) for a population of 2,000 families, showed an adoption rate of the practices of almost $100 \%$ in six years (Figure 12).

\begin{tabular}{|l|c|c|c|c|}
\hline & $\mathbf{2 0 0 9}$ & $\mathbf{2 0 1 1}$ & $\mathbf{2 0 1 3}$ & $\mathbf{2 0 1 5}$ \\
\hline No burning & $17 \%$ & $95 \%$ & $95 \%$ & $100 \%$ \\
\hline Mulching & $17 \%$ & $90 \%$ & $93 \%$ & $100 \%$ \\
\hline Agroforesty & $20 \%$ & $80 \%$ & $86 \%$ & $99 \%$ \\
\hline Barriers & $14 \%$ & $56 \%$ & $63 \%$ & $96 \%$ \\
\hline
\end{tabular}

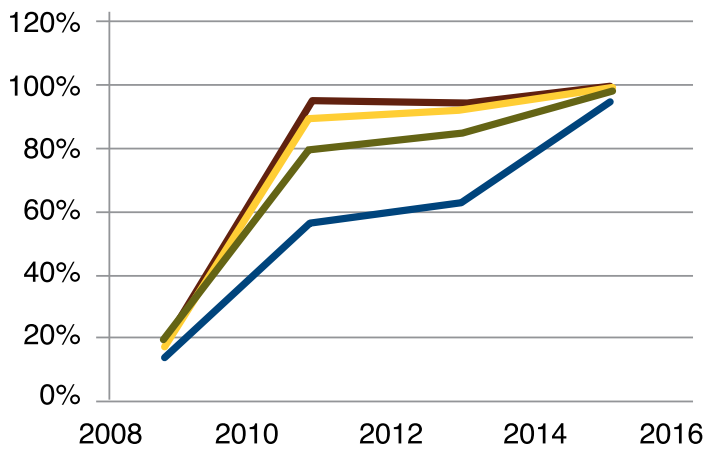

Figure 12.

Kuxur rum adoption by FAO project participants in Rabinal and Santa Cruz El Chol municipalities in Baja Verapaz

Source: Compiled by the author, based on the reports and records of Food Security Special Programme (FAO, 2006).

The investment to establish the kuxur rum agroforestry system practice is not as expensive as other traditional practices (more than $50 \%$ of the costs were family labour as described in Table 7). 
Table 7.

Cost of implementing the agroforestry approach over 1 hectare in the first year

\begin{tabular}{llcccc}
\hline & Description & $\begin{array}{c}\text { Unit of } \\
\text { measurement }\end{array}$ & Unit price (US\$) & Quantity & Total (US\$) \\
\hline 1 & Family labour & Labour day & 10.00 & 100 & $1,000.00$ \\
\hline 2 & $\begin{array}{l}\text { Technical assistance and } \\
\text { training }\end{array}$ & Labour day & 20.00 & 10 & 200.00 \\
\hline 3 & Tree seeds & Cuttings & 0.10 & 1,666 & 166.60 \\
\hline 4 & Certified corn seed & Bag & 100.00 & 1 & 100.00 \\
\hline 5 & Certified bean seed & Bag & 150.00 & 1 & 150.00 \\
\hline 6 & Fertilizer & Bag & 30.00 & 10 & 300.00 \\
\hline & TOTAL & & & $1,916.60$ \\
\hline
\end{tabular}

Source: Compiled by the author, based on the reports and records of FAO projects (FAO, 2006).

The total cost of establishing this agroforestry system is around US $\$ 1,916.60$ per hectare. One hectare is enough to supply staple crops for a family of six for one year. The investment is highest (labour and cuttings) in the first year, for the subsequent years the cost of maintaining the practice is lower by at least 30\%.

According to San Carlos National University USAC, Guatemala, in 1996 there was an estimated cost of around US $\$ 2,000$ per hectare for the loss of soil and fertility - representing an average loss of 29 metric tonnes over two years (USAC, 1996). In economic terms, there is a value to investing in agroforestry projects, because the cost of not reducing soil erosion is higher than the investment required per hectare, and it has the added benefit of providing household food security.

Is important to mention the analysis The cost of hunger: Social and economic impact of child undernutrition in Central America and the Dominican Republic conducted by the United Nations Economic Commission for Latin America and the Caribbean (ECLAC) and World Food Programme (WFP) (ECLAC, WFP, 2008). This study evidenced that chronic malnutrition has a negative economic impact on people's lives and society. In addition, the study highlights the effects on health and education, by increasing the demand for services and increasing public and private spend, while lowering the production capacity of people. In Guatemala, according to this study, the cost of hunger and malnutrition amounts to over $11 \%$ of gross domestic product (GDP). 


\section{Research questions and methods}

In 2000, the FAO technical team of the Food Security Special Programme (FAO, 2006) identified and improved the ancient Guatemalan practice of agroforestry. The programme had three different phases of implementation at field level: following identification in 2000, validation (2001-2004); scaling up (2004-2014); and then final systematization from 2015.

Data over the 15 years have come from two categories of reports and evaluations:

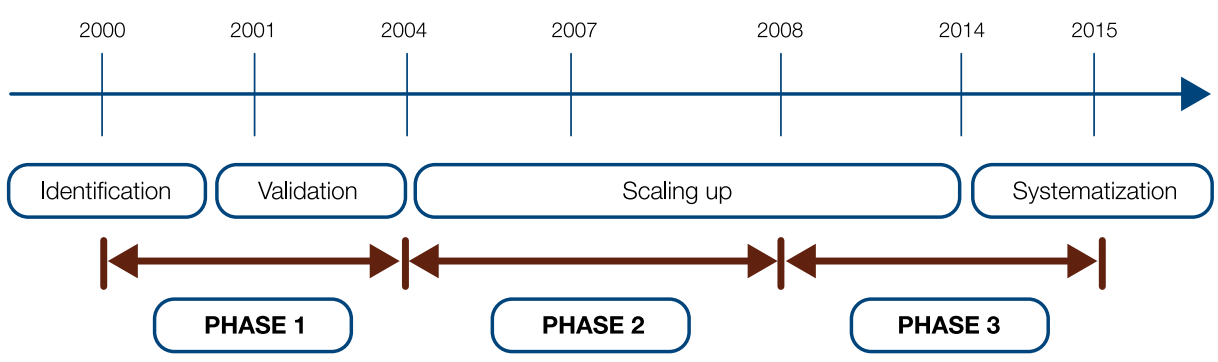

Figure 13.

Timeline for developing the practice of kuxur rum

Source: Compiled by author, based on the reports and records of the Food Security Special Programme (FAO, 2006).

Monitoring and evaluation of project performance: A continuous process to collect information from the implementation of project activities over the three phases compared with those scheduled in annual work plans, including identifying lessons learned and best practices for scaling up.

Monitoring and evaluation of project impact: Evaluation of project successes in achieving outcomes via continuous monitoring throughout the project. The key indicators can be found in the logical framework. The indicators, tools and methods reviewed during development of the three phases, to measure impact, were gathered by participatory survey methods (Table 8). 
Table 8.

Participatory survey methods for gathering information

Source: FAO guide for the conduct of the constraints analysis component and based on the reports and records of the Food Security Special Programme (FAO, 2006).

SEMI-STRUCTURED INTERVIEWING

GENERAL INFORMATION EVENTS
- Location of demonstration and implementation area

- Agro-ecological zone

- Main economic activities of local population

- Physical resource base: land, soil, water, vegetation, etc.

- Land use patterns: agriculture, livestock, forestry activities

- Cropping patterns: crops, varieties, patterns, rotations, varietal preferences

- Assets available (e.g. major tools)

- Yields per crop per unit of land

- Quantities of physical, variable inputs used per crop per unit of land

- Labour used per crop per unit of land

- Prices: inputs, outputs, labour, land, capital

- Land tenure

- Interest groups

- Labour use patterns

- Access to services and markets

- Cultural attitudes towards farming

- Distribution of assets

- Gender roles

\section{MAPPING AND DIAGRAMS}

- Individual fields

- Farms

- Communities

- Districts

- Watershed

- Private

- Public

- Cooperation

- Social/civi

- Production season per year

- Food availability

- Rainfall and temperature

- Production and post-harvest activities

- Prices crisis

\section{KNOWLEDGE, ATTITUDE AND PRACTICE SURVEYS}

- Values and belief systems and how these affect farming practices

LOCAL INDIGENOUS KNOWLEDGE • Identify those elements which may be good, those which may need to be improved, and those which may need to be discouraged

\begin{tabular}{ll}
\hline \multicolumn{2}{c}{ QUANTITATIVE ASSESSMENT } \\
\hline ASSESSING PAST PRODUCTION & $\bullet$ History of food production records (baseline) \\
\hline ASSESSING CURRENT PRODUCTION & $\bullet$ Estimated food production records \\
\hline ASSESSMENT OF GRAIN STORAGE & $\bullet$ Monthly reserve of grains \\
\hline
\end{tabular}


The programme had set performance indicators (and scale rate adoption) based on the logic framework. The indicators were calculated at different levels and were selected for positive and negative impacts on food and nutrition security at the households.

The programme had set indicators in order to provide parameters against which to assess project performance and achievement in terms of quantity (corn and beans yields), time (years from 2000 to 2015), target group (family farmers) and quality (monthly grain reserve). Quantitative indicators included: number of families, number of hectares, percentage of adoption, and qualitative: benefits perception from farmers.

The programme started with a baseline review on the character of the area and biophysical and socioeconomic data collection. This baseline allowed evidencing of positive changes in the four dimensions of food security according to the indicators (Table 9). However, for food security objectives to be realized, all four dimensions must be fulfilled simultaneously.

\begin{tabular}{ll}
\hline AVAILABILITY & $\begin{array}{l}\text { Food availability addresses the 'supply side' of food security and is determined by the } \\
\text { level of food production, stock levels and net trade. }\end{array}$ \\
\hline \multirow{3}{*}{ ACCESS } & $\begin{array}{l}\text { An adequate supply of food at the national or international level does not in itself } \\
\text { guarantee household level food security. Concerns about insufficient food access } \\
\text { have resulted in a greater policy focus on incomes, expenditure, markets and prices } \\
\text { in achieving food security objectives. }\end{array}$ \\
\hline UTILIZATION & $\begin{array}{l}\text { Utilization is commonly understood as the way the body makes the most of various } \\
\text { nutrients in the food. Sufficient energy and nutrient intake by individuals are the result } \\
\text { of good care and feeding practices, food preparation, diversity of diet and intra- } \\
\text { household distribution of food. } \\
\text { Combined with good biological utilization of food consumed, this determines the } \\
\text { nutritional status of individuals. }\end{array}$ \\
\hline STABILITY & $\begin{array}{l}\text { Adverse weather conditions, political instability, or economic factors (unemployment, } \\
\text { rising food prices) may have an impact on your food security status. }\end{array}$ \\
\hline
\end{tabular}

Source: An Introduction to the Basic Concepts of Food Security (FAO, 2008).

The unit of study was households and farms, with randomly selected sample beneficiaries to assess livelihoods, agricultural production, resilience and food security. The sampling size varied over the 15 years (there were required samplers for the three phases), but was always at least $10 \%$ of the total population (number of farms and households). The margin of error was $5 \%$ and confidence level $90 \%$.

Also the sample for data collection was based on geographical locations from the six provinces (Chiquimula, Jutiapa, Jalapa, Zacapa, El Progreso and Baja Verapaz) and 25

Table 9.

Four dimensions of food security 
municipalities. A homogenized target population from the beneficiary households was defined. The target profile of respondents was based on the following criteria:

- The farm was managed and operated by family members and predominantly reliant on family labour;

- Poor access to natural resources and technologies;

- Staple crops (corn and bean) were the main production;

- Average of 1 hectare of cropping area;

- The diet of the family was based on corn and beans;

- Farm located in dry corridor territory;

- Vulnerable to becoming food insecure.

The data was collected by the technical team of FAO, MAGA, Commonwealth Copan Ch'orti' (an intergovernmental provincial organization) and family farmer leaders. 


\section{Case study results}

The results indicate that kuxur rum agroforestry practice contributes to the four main dimensions of food and nutrition security: availability, access, utilization and stability.

\section{Availability of food: Increasing crop productivity, principally of staple crops}

The families that participated in the project reported, on average, an increase of $50 \%$ in corn yields (Figures 14 and 16).

The families who participated in the project reported, on average, an increase of 9\% in bean yields (Figures 15 and 16).

In seven years, the number of months with reserves of grains, increased from 5.4 to 7.9 months for beans and from 2.6 to 6.7 months for corn (Figure 16). This increase in reserves is associated with the increase in yields and was strengthened with the FAO training in post-harvest and storage techniques.

The increase in farm system performance is directly associated with the improvement of the soil and water conservation, especially in the drought period which occur from July to August (canicula) when the range of days without rainfall is from 15 to 45 days in the dry corridor (Figure 18).
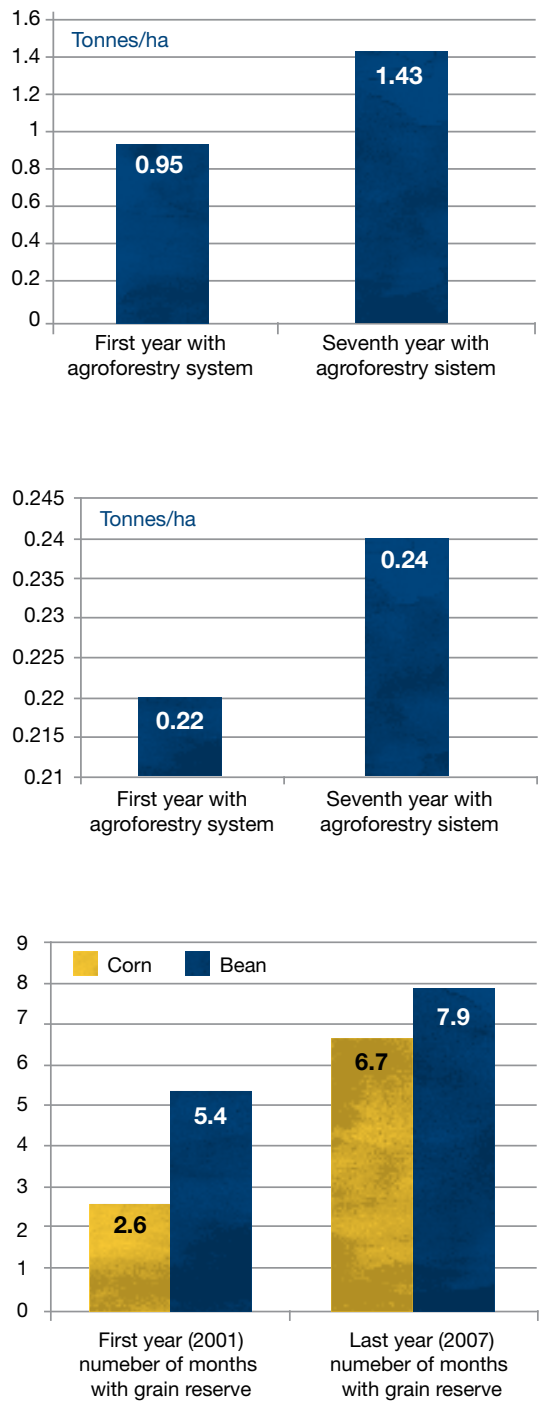

Figure 14.

Corn yield in the plots adopting the kuxur rum agroforestry system

Source: Compiled by author, based on the reports and records of the Food Security Special Programme (FAO, 2014a)

Figure 15.

Bean yields in the plots adopting the kuxur rum agroforestry system

Source: Compiled by author, based on the reports and records of the Food Security Special Programme (FAO, 2014a).

Figure 16.

Evolution of monthly grain reserve in households adopting the kuxur rum agroforestry system 2001 to 2007

Source: Compiled by author, based on the reports and records of the Food Security Special Programme (FAO, 2014a). 
Figure 17.

(Zacapa, Guatemala)

(photo credit:

CFAO/José Ramírez

Maradiaga)

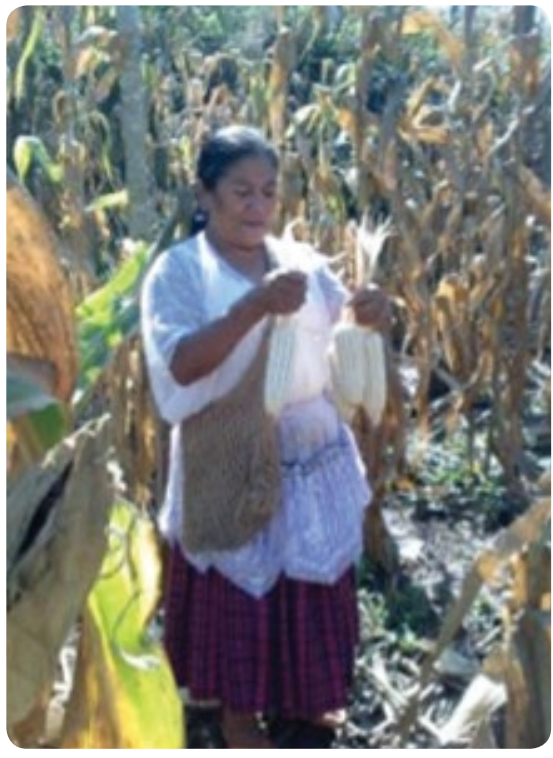

Harvesting corn

The reports indicated that the farmers that implemented kuxur rum had fewer crop losses related to extended drought periods and other climatic phenomena. The soil tested in plots with kuxur rum allowed an understanding of how the agroforestry system improves crop performance.

Figure 19 shows the increasing percentage of organic matter content over time with the kuxur rum system. One of the most important functions of the organic matter is to improve the soil and its capacity to hold and retain water. In Figure 20, we can appreciate how the older agroforestry systems with greater percentages of organic matter perform better in drought periods.

Figure 18.

Annual rainfall average in Huité, Zacapa (a representative province of the dry corridor)

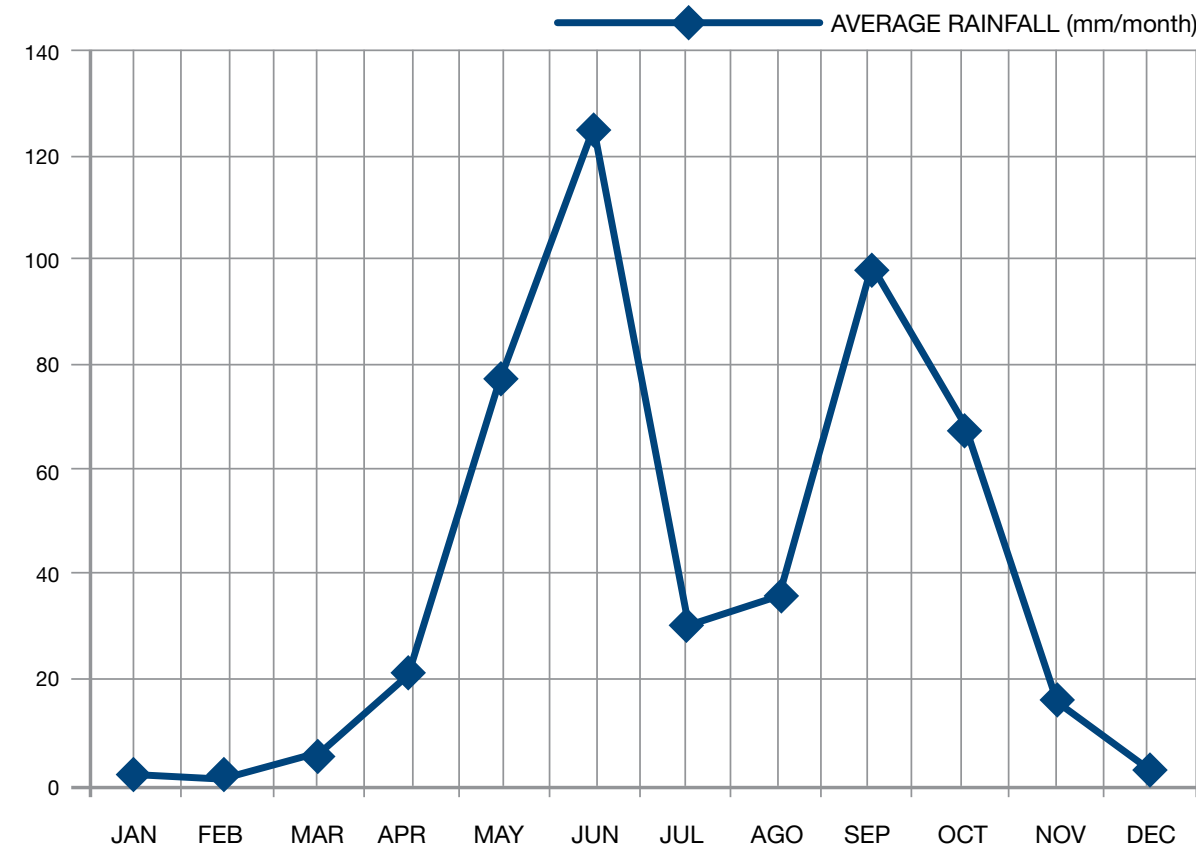

Source: Compiled by author, based on the data from National Institute of Seismology, Volcanology, Meteorology and Hydrology (INSIVUMEH, 2014). 


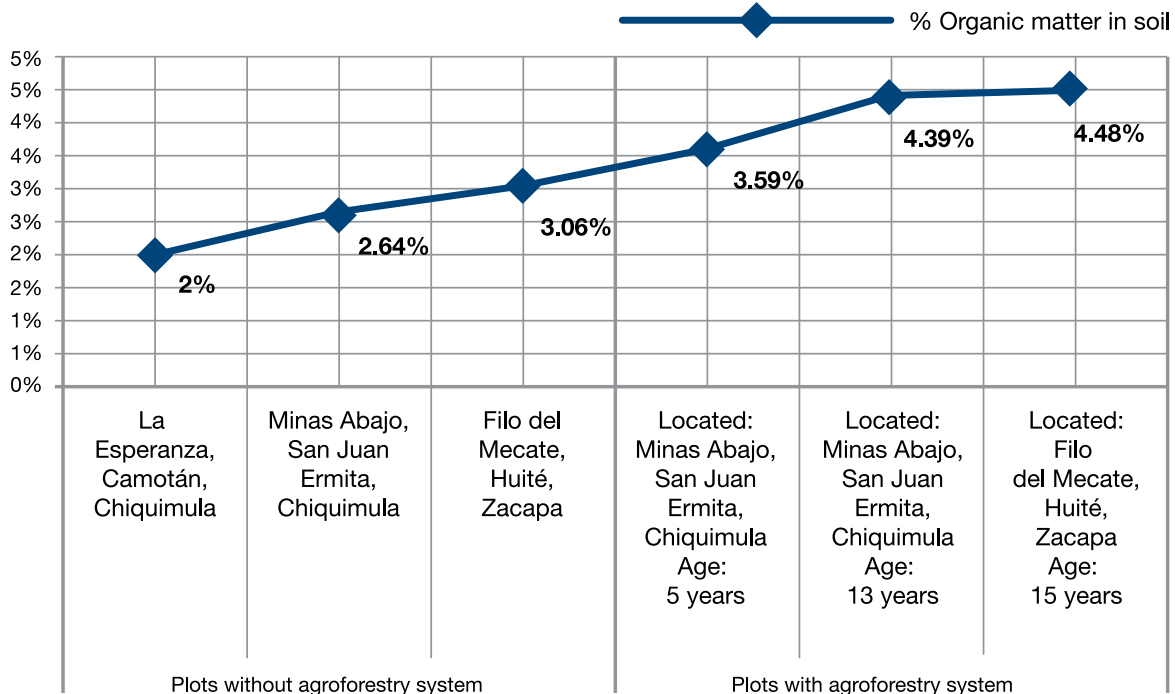

Source: Compiled by the author, based on the soil tested in the environmental laboratory of the University of San Carlos, Guatemala, 2015.

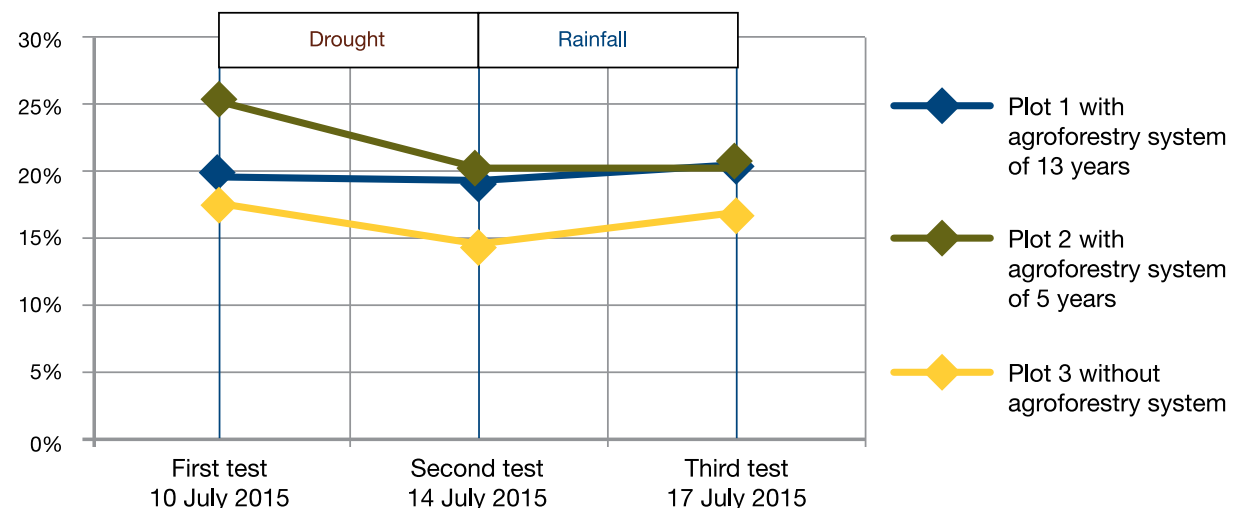

Source: Compiled by the author, based on the soil tested in the environmental laboratory of the University of San Carlos, Guatemala, 2015.
Figure 19.

Organic matter content in soil in plots under agroforestry system kuxur rum compared with plots without an agroforestry system

Figure 20.

Soil moisture content with and without agroforestry system kuxur rum 
Figure 21.

Corn production under kuxur rum (Huité,

Zacapa, Guatemala)

(photo credit: (OFAO/José

Ramirez Maradiaga)

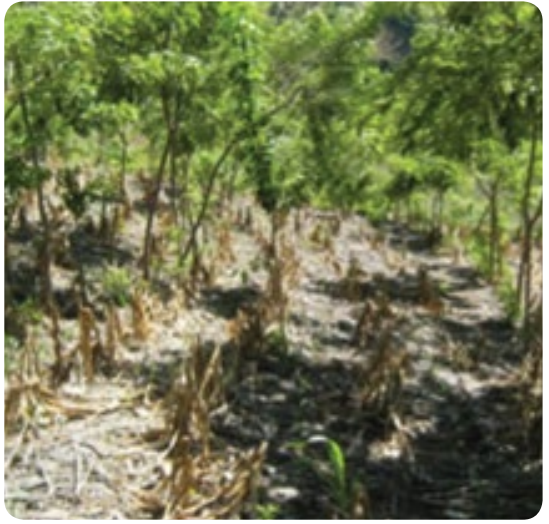

Figure 22. Firewood for cook food at a traditional stove (Plan de Nuevo Candelero, Jocotán, Chiquimula) (photo credit: (OFAO/José Ramírez Maradiaga)

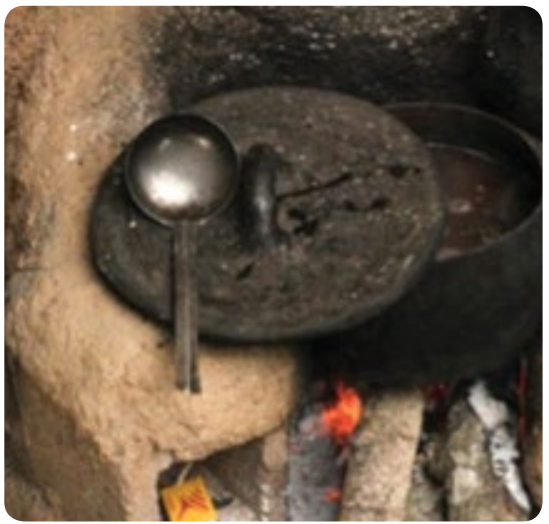

Figure 23.

Kuxur rum before harvesting (photo credit: (OFAO/José Ramirez Maradiaga)

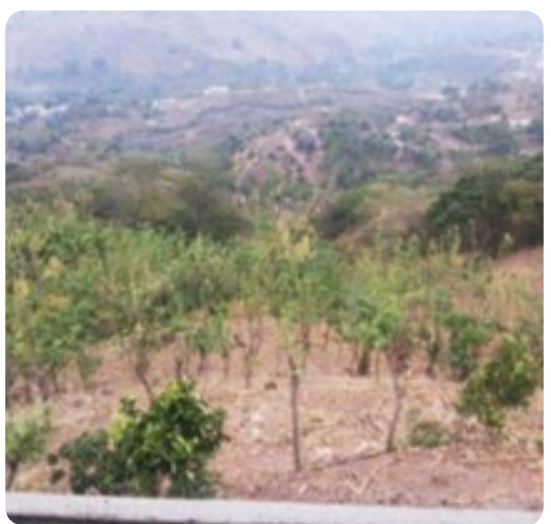

In the July 2015 drought period the percentage of moisture in the soil was monitored in three different plots at the same location of Chiquimula province; one farm having practised kuxur rum for 13 years old, a second for five years; and a third without an agroforestry system.

It can be appreciated that the plots under kuxur rum for 13 years (blue line) kept the same soil moisture in the drought period, not losing moisture between 10th and 17th of July, being the most stabilized farm system, and even increasing the moisture by $1 \%$. The plot with kuxur rum for five years (red line) lost 3.2\% of its moisture in the four days of drought, and gained $2.40 \%$ in the three days of rain, losing in total only $0.8 \%$ of its moisture. The green line that represents the farm without an agroforestry system started with 25\%, and then lost 5\% in the four days of drought, and then gained only $0.10 \%$ in the three days of rain, losing in total $4.9 \%$ of its moisture - this was the least stabilized system.

Figure 20 shows how the soil in agroforestry systems can conserve moisture, especially with the use of mulch to reduce evapotranspiration; and shade from trees. Farmers' testimonies indicate that with agroforestry crops survive at least 20 to 25 days with no rainfall, instead of only 10 to 15 in conventional farming practice. 


\section{Access to food: Diversification of agricultural products and services}

The kuxur rum agroforestry system brings the opportunity for family farmers to live in harmony with nature by making better use of the natural resources and ancestral knowledge as a strategy for sustainable livelihoods.

The use of Gliricidia sepium in the farm system provides additional products and services to family farms:

- Availability of firewood: According to the national forestry institute (INAB, 2012), the annual consumption of firewood for a household of six members is around $3.63 \mathrm{~m}^{3}$, and the harvest of Gliricidia sepium from 1 hectare provide an average supply of around $50 \%$. This reduces the pressure on the forest and allows financial savings and labour reduction for the women who usually recollect firewood.

- Availability of wood for fences (hedges), construction material, materials for processing (broomsticks) and other handicrafts.

- Availability of fodder for small cattle and chickens.

- Production of foliar fertilizer and rodenticide.

The kuxur rum practice allows families to diversify their diet, as the improvement of soil facilitates the production of a range of vegetables. Table 11 illustrates the diversification of livelihoods through kuxur rum practices and traditional system of production.

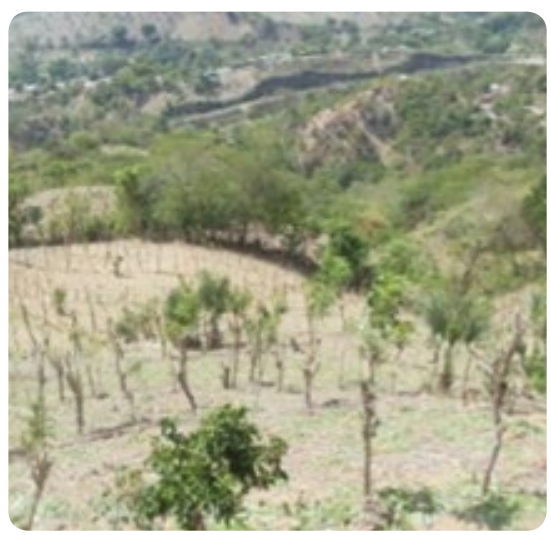

Figure 24.

Kuxur rum after

harvesting

(photo credit: @FAO/José

Ramírez Maradiaga)

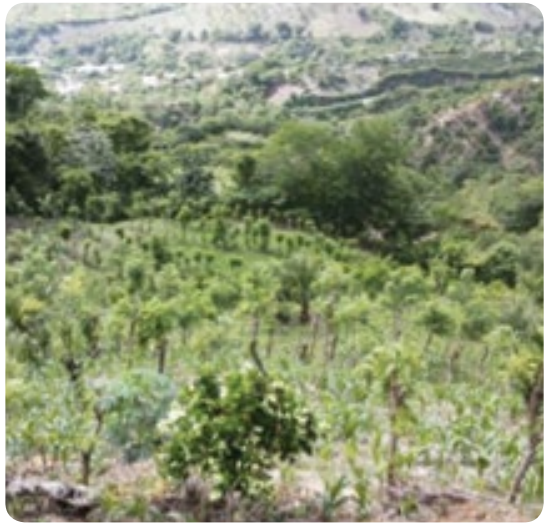

Figure 25.

Kuxur rum with corn production

(photo credit:

(C)FAO/José Ramirez

Maradiaga)

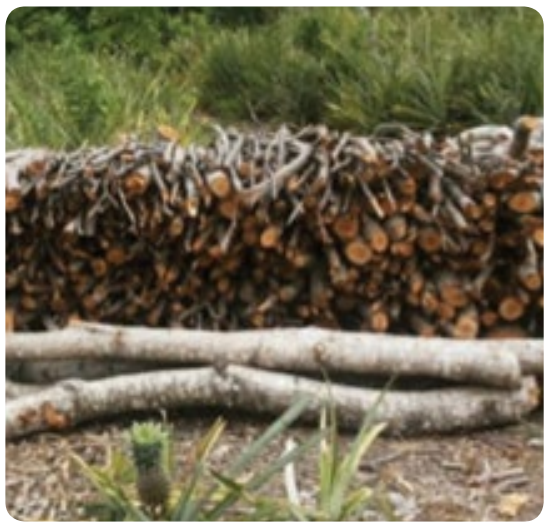

Figure 26.

Firewood from the agroforestry system

(Tierra Nueva, Camotan, Chiquimula)

(photo credit: CFAO/José Ramírez Maradiaga) 
Table 10.

Agroforestry system diversification compared with traditional production system
Traditional system without agroforestry systems (slash-and-burn plots)

\begin{tabular}{|c|c|c|c|}
\hline \multirow[t]{6}{*}{$\begin{array}{l}\text { Basic grains } \\
\text { - Corn Zea mays } \\
\text { - Frijol Phaseolus vulgaris }\end{array}$} & \multirow[t]{2}{*}{$\begin{array}{l}\text { - Sorgum Sorghum } \\
\text { bicolor } M\end{array}$} & \multicolumn{2}{|l|}{$\begin{array}{l}\text { Basic grains } \\
\text { - Corn Zea mays } \\
\text { - Frijol Phaseolus vulgaris }\end{array}$} \\
\hline & & $\begin{array}{l}\text { Green vegetables } \\
\text { - Crotalaria longirostrata } \\
\text { - Solanum nigrum } \\
\text { - Fernaldia pandurata } \\
\text { Coriandrum sativum }\end{array}$ & $\begin{array}{l}\text { - Brassica oleracea } \\
\text { italic } \\
\text { - Cucúrbita pepo } \\
\text { - Beta vulgaris var. cicla }\end{array}$ \\
\hline & & $\begin{array}{l}\text { Yellow vegetables } \\
\text { - Cucurbita moschata } \\
\text { - Daucus carota }\end{array}$ & - Amaranthus cruentus \\
\hline & & $\begin{array}{l}\text { Tubers and roots } \\
\text { - Ipomoea batatas } \\
\text { - Manihot esculenta }\end{array}$ & $\begin{array}{l}\text { - Solanum tuberosum } \\
\text { - Raphanus sativus }\end{array}$ \\
\hline & & $\begin{array}{l}\text { Perennial crops } \\
\text { - Coffee Coffea arabica }\end{array}$ & \\
\hline & & $\begin{array}{l}\text { Fruits } \\
\text { - Musa paradisiaca }\end{array}$ & \\
\hline
\end{tabular}

Source: Compiled by the author, based on reports and records of the Food Security Special Programme (FAO, 2006).

The kuxur rum system allows the cultivation of basic grains combined with other vegetables, tubers and cucurbits - sources of energy, protein, vitamins and minerals. The traditional system of farming produces only basic grains leaving families lacking micronutrients and proteins.

\section{Utilization: Reduction in water deterioration and unsafe food}

According to FAO, food intake must be sufficient and safe to meet the physiological requirements of each individual. For food to be safe it has to be free from organic and inorganic contaminants. Apart from the function of trees in purify water, the kuxur rum agroforestry system reduces the use of chemicals in fertilizers and pest control thus reducing the risk of water contamination.

The records from farmers reported a decrease in the use of chemical fertilizers and herbicides, allowing farmers to reduce their exposure to pollution by agrochemicals that affect health. In addition, by not burning the land, the risks tend to be lower for respiratory diseases, and the existence of different sizes of trees on plots allows producers to work under less sun exposure. 
The dry corridor is facing an increase in the frequency and severity of disasters. In the period between 2014 and 2015 more than 300,000 households were affected each year by disasters, predominantly floods and tropical storms, followed by droughts; family farmers are the most sensitive sector.

In order to reduce the risks related with climatic phenomena the kuxur rum practice brings the following measures:

- Appropriate crop selection and improved seeds (introducing varieties with drought resistant and quick crowing crops);

- Improved cropping systems and cultivation methods (crop diversification, intercropping, etc.);

- Adjustment of cropping calendars;

- Soil conservation;

- Sustainable water management and water conservation techniques; and

- Specific infrastructural (windbreaks, erosion control structures, etc.)

It can also mitigate greenhouse gas emissions by accumulating more biomass and carbon stocks and reduce burning of organic matter. Coordination with stakeholders has enabled boosting of the impacts at different levels, building capacities in rural areas to institutionalize the intervention at a larger scale.

Between 2005 and 2006, through the kuxur rum practice, it was possible to establish about 1,100 hectares of this agroforestry system, bringing benefits in the medium and long term of vegetation cover, and generating impacts related to water retention and soil improvement.

Figure 29. Scaling up kuxur rum practice (Huité, Zacapa, Guatemala) (photo credit: (C)FAO/José Ramirez Maradiaga)

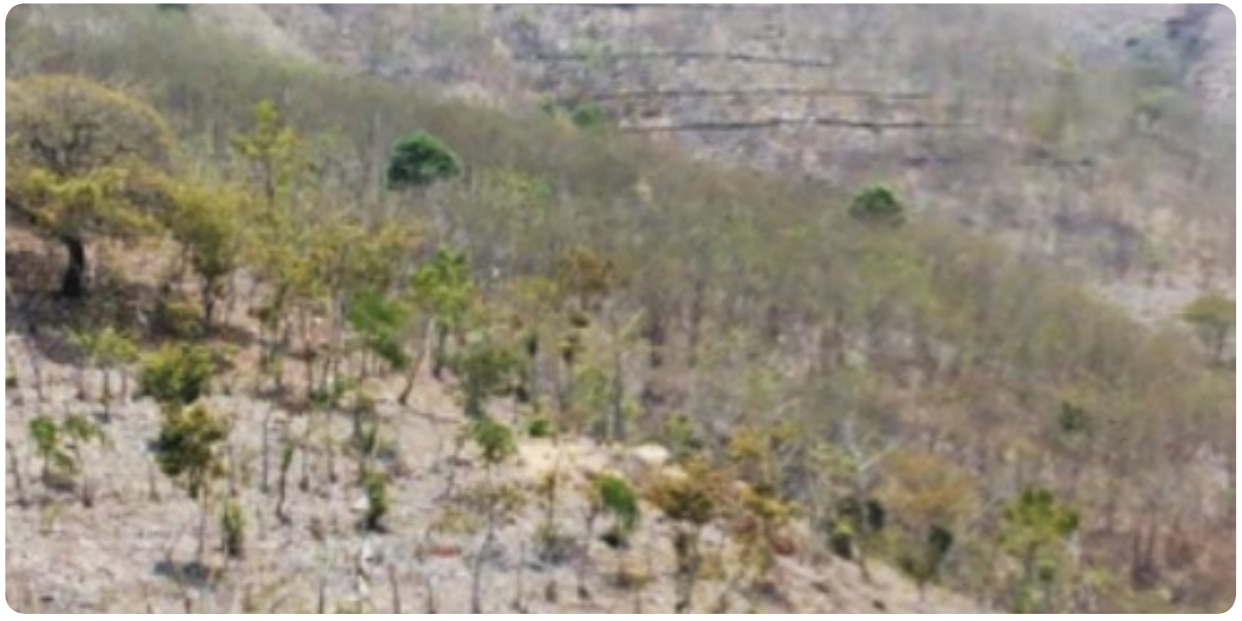




\section{Conclusion and recommendations}

Based on this analysis, the kuxur rum agroforesty system is a proven good practice in improving food and nutritional security and in contributing to the four dimensions of food security.

\begin{tabular}{ll}
\hline AVAILABILITY & Direct provision of food by supporting production and increasing yields \\
\hline \multirow{3}{*}{ ACCESS } & Providing varied and nutritionally balanced diets \\
& Raising farmers' incomes and savings to support access to food \\
& Providing fuel for cooking \\
& Bringing various ecosystem services \\
\hline UTILIZATION & Purify water \\
Reduce farmers' exposure to pollution by agrochemicals & Reduce the risks from respiratory diseases \\
& Less exposure to sun \\
\hline Improving soil fertility \\
Providing shade for moisture conservation \\
Trees can modify the microclimate \\
Stabilize crop production in drought years and during other extreme weather \\
events, and improve crop rain use efficiency in the context of climate change \\
Watershed protection, animal and plant biodiversity conservation
\end{tabular}

It is a proven good practice because it also addresses the following criteria:

\section{Based on local knowledge and requires low-cost and low-input technology:} Agroforestry system kuxur rum established through a participatory process, is a practice with cultural relevance, revitalizing and perpetuating ancient and traditional ecological knowledge. It allows farmers to take advantage of local natural resources and decreases dependence on foreign inputs.

Spontaneously adopted by farmers after the initial testing: The results of kuxur rum have been appreciated by farmers, especially for the resulting increase in yields and better soil moisture retention. The practice has been adopted by $85 \%$ of participants in the first two years and by $99 \%$ after six years.
Table 12.

How kuxur rum contributes to food security 
Decreases vulnerability to food insecurity through food production and

diversification: Households adopting kuxur rum can overcome unstable harvests and local food shortages and maintain their access to food and income.

Effective for more than one agricultural cycle: Kuxur rum is an alternative practice allowing smallholder families to coexist with drought. It restores livelihoods, builds resilience and safeguards the local agro biodiversity.

Land tenure rights are particularly important for agroforestry compared with other agricultural practices because of the relatively long period that may be required to realize benefits.

\section{Recommendations}

\section{Policy makers}

- It is necessary to increase awareness of decision makers at global, regional, national and local level about the linkages between forest landscape restoration, food security and family farming.

- It is important to invest in research to determine the impact of agroforestry systems in supporting food and nutritional security.

- The concept of FLR via the kuxur rum agroforestry system should be strengthened and institutionalized. It should be mainstreamed and harmonized into current strategies, policies and programmes (including considerations of gender and indigenous people).

- Develop differentiated policies and programmes aimed at protecting human rights, reforming financial aid and tenure systems in order to promote and link with agroforestry system initiatives.

- Analyse policy, legal and institutional frameworks and identify favourable and unfavourable conditions, key factors and restrictions that affect the adoption and dissemination of agroforestry systems - here it is important to identify the right methodology to spread kuxur rum and promote sustainable management.

- Recognize the option of agroforestry as a realistic alternative to invest in in the context of climate change, rather than the provision of traditional inputs.

\section{Technical professionals}

- Design a practical training programme about FLR, food security and family farming for rural extension service and farmers leaders.

- Ensure technical assistance to vulnerable and extremely poor family farmers for at least 
three years and combine the intervention with social protection and humanitarian help. In areas where there is no rural extension service partnerships between private and public sectors are key elements.

- Intersectoral coordination is essential; especially agriculture, environment protection, forestry, development health and social protection.

- Strengthen and institutionalize the platforms and networks of family farmers to scale-up agroforestry systems.

- Identify the ecosystem services with the potential to link with markets.

\section{Family farmers}

- At the beginning, test the implementation of kuxur rum in a small part of the farm, before extending it to the whole farm.

- The kuxur rum agroforestry system is an open system that can be integrated and complemented with other technologies and practices according to the experience and the objectives of the families. 


\section{References}

Bonn Challenge (2015). Online consultation Bonn Challenge website. Available: http://www.bonnchallenge.org/content/ challenge (accessed 23 September 2015).

CATIE (2012). Impacto del Sistema Agroforestal Kuxur Rum en la sostenibilidad de los medios de vida de las familias rurales en Camotán y Jocotán, Guatemala. Costa Rica.

CONAP, INAB, CONRED MARN (2010). Sistema de Información Geoespacial para Manejo de Incendios en la República de Guatemala (SIGMA-1).

CONAP (2013). Secretaría Ejecutiva del Consejo Nacional de Áreas Protegidas (CONAP), Integración de estadística e indicadores ambientales oficiales del CONAP. Fase IV. Unidad de Seguimiento y Evaluación. Departamento de Planificación, Estudios y Proyectos, Guatemala.

ECLAC, WFP (2008). The cost of hunger: Social and economic impact of child undernutrition in Central America and the Dominican Republic. Economic Commission for Latin America and the Caribbean, World Food Programme.

FAO (2005). Global forest assessment, progress toward sustainable forest management. Rome, Italy: Food and Agriculture Organization.

FAO (2006). Guatemala, Buenas Prácticas para la Seguridad Alimentaria Nutricional (BP-SAN) de los Programas PESA en Centroamérica; and Registros de logros, informes semestrales y anuales, reportes de evaluación de programas. Guatemala 2001-2002-2003-2004-2005-2006. Guatemala: Food and Agriculture Organization.

FAO (2008). An Introduction to the Basic Concepts of Food Security. Rome, Italy: Food and Agriculture Organization.

FAO (2008a). Climate Change and Food Security: A Framework Document. Rome, Italy: Food and Agriculture Organization.

FAO (2012). Programas Especiales para la Seguridad Alimentaria (PESA) en Centroamérica 2010, Sistemas Agroforestales, Seguridad Alimentaria y Cambio Climático en Centroamérica. Panama: Food and Agriculture Organization.

FAO/ACH (2012). Estudio de caracterización del Corredor Seco Centroamericano. Tegucigalpa, Honduras.

FAO (2014a). Hambre de Saber, Saber de Hambre. Programa Especial para la Seguridad Alimentaria (PESA) Centroamérica.

FAO (2014b). Multi-Partner Programme Support Mechanism (FMM), Concept Note Climate-Smart Agroforestry Systems for the Dry Corridor of Central America. Panama: Food and Agriculture Organization.

Hughes, C.E. (1987). Biological considerations in designing a seed collection strategy for Gliricidia sepium. Commonwealth Forestry.

INAB (2012). Oferta y demanda de leña en la República de Guatemala. Instituto Nacional de Bosque en colaboración con IARNA y FAO.

INE (2011). Living Conditions Survey. Instituto Nacional de Estadística (National Statistics Institute) Guatemala.

INE (2013). Caracterización estadística, Republica de Guatemala. Instituto Nacional de Estadística (National Statistics Institute) Guatemala. 
INSIVUMEH (2014). Available at: http://www.insivumeh.gob.gt [accessed 23 October 2015].

IUCN (2014). Guatemala, Análisis del marco normativo y regulatorio, mapeo de iniciativas y diagnóstico de la situación de la restauración del paisaje forestal en Guatemala. IUCN: Guatemala.

MAGA (2012). Family Agriculture Program to Strengthen the Rural Economy. Ministry of Agriculture, Livestock and Food, Guatemala.

Pertchik, B. and Pertchik, H. (1951). Flowering Trees of the Caribbean. New York: Rhinehart \& Co.

SESAN (2012). Zero Hunger Pact. Secretariat for Food Security and Nutrition, Guatemala.

Simons, A.J. and Stewart, J.L. (1994). 'Gliricidia sepium - a multipurpose forage tree legume'. In: Gutteridge, R.C. and Shelton, H.M.J. (eds) Fodder Tree Legumes in Tropical Agriculture. Wallingford, UK: CABI, 30-40.

UNDP (2015). Online consultation on the Millennium Development Goals for UNDP Guatemala web site. See: http://www. gt.undp.org/content/guatemala/es/home/mdgoverview/ (accessed 23 September 2015).

UNEP (2010). Convention on Biological Diversity, report of the parties to the convention on biological diversity. Report of the 10th Meeting of the Conference of the Parties to the Convention on Biological Diversity. Nagoya, Japan.

USAC (1996). Evaluación económica de la erosión, propuesta de un modelo matemático. Facultad de agronomía, Univesidad de San Carlos de Guatemala.

USAID (2011). USAID Country Profile: Property rights and resource governance, Guatemala.

Van den Berg, H. (2004). IPM Farmer Field School: A synthesis of 25 impact evaluations. Rome, Italy: Food and Agriculture Organization. 


\section{Mangrove forest restoration in northern Viet Nam}

Nguyen Thi Kim Cuc

Department of Natural Resources Management, Faculty of Water Resources Engineering Thuy Loi University, Dong Da, Hanoi, Viet Nam; Mangrove Ecosystem Research Division, Centre for Natural Resources and Environmental Studies, Viet Nam National University, Hanoi, Viet Nam 


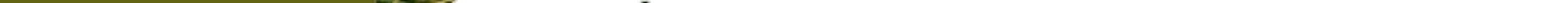




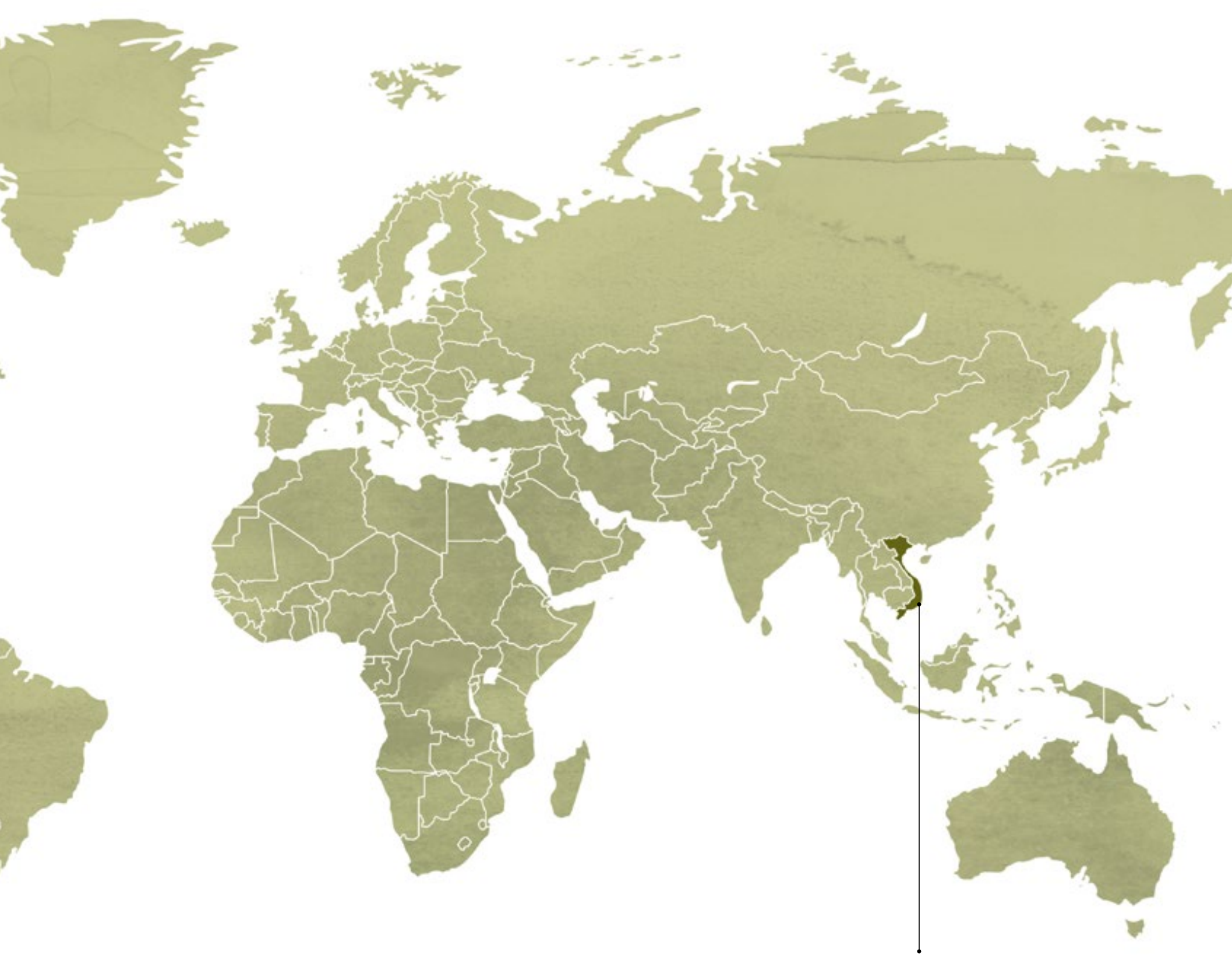

\section{Viet Nam}

Country in Asia

Size: cca $332,698 \mathrm{~km}^{2}$

Population: 89.71 million (2013, World Bank)

Capital: Hanoi 


\section{Introduction}

Mangroves are among the most important and productive ecosystems in tropical and subtropical regions (Hong \& San, 1993; Ong, 1993). According to the Millennium Ecosystem Assessment (2005) and other authors (Alongi, 2008, 2009; Giesen, et al., 2007; Mitsch \& Gosselink, 2007; Hogarth, 1999; Tri, et al., 1998), mangroves provide multiple benefits under four categories of ecosystem services:

Provisioning: source of food (fish, shellfish, crabs, etc.), timber, fuelwood, building materials;

Regulating: carbon sequestration, pollination, coastline stabilization and, in many cases, promotion of coastal accretion, providing a natural barrier against storms, cyclones, tidal bores, flooding and other potentially damaging natural forces;

Cultural: tourism, spiritual, cognitive and aesthetic value

Supporting: cycling of nutrients, nursery habitats for many commercially important aquatic organisms.

The two most important categories are provisioning (through habitats) and regulating (by acting as ecological buffers to the destructive forces of extreme weather events) services. Mangroves contribute significantly to the economies of coastal communities and, as such, their maintenance is important for livelihoods and food security throughout the Pacific (UNEP-WCMC, 2006). From a food security and livelihoods perspective, mangroves support many types of fisheries - artisanal, commercial and recreational - of numerous types of fish, lobsters, crabs, molluscs and many other species. These ecosystems are prominent features of Pacific island landscapes and offer significant opportunities to reduce the impact of climate change on food security across the Pacific.

While upland and floodplain forest-based adaptation solutions have limited application across the Pacific, adaptation options that take advantage of the ecosystem services associated with coastal and marine ecosystems have much broader scope for application. However, relative to the options available to terrestrial and coastal production systems, there is less that can be done to buffer the climate change impacts on marine systems. As a consequence, the ecosystem-based adaptation options that are most likely to add resilience to ecosystem services are those that remove other anthropogenic stressors, such as pollution, sedimentation, unsustainable fishing practices and poor coastal development planning. While mangroves can protect food security by reducing the intensity of climate- 
related events, such as storm surges, before they reach areas of human settlement, the ecosystems themselves are usually damaged in such events.

Thus their buffering capacity is a balance of both their resilience and vulnerability (UNEP-WCMC, 2006). In order to optimize the 'bounce back' of these ecosystems from such events, their resilience can be strengthened by minimizing anthropogenic stressors.

In Viet Nam, with about 169,000 ha of mangroves spreading around the 3,260km coastline (FIPI-MARD, 2013), mangroves are considered an important resource for socioeconomic development in the country. Despite their importance, mangrove forests declined significantly over recent decades from 408,500 ha in 1943 (Maurand, 1943) to 197,200 ha in 2007 (FIPI-MARD, 2007). The primary causes of mangrove loss and degradation have been population pressure, wood/firewood extraction and conversion to other land uses such as shrimp ponds, agricultural fields, salt pans, settlements, ports and coastal industrialization (Hong, 1991; Hong \& San, 1993; Macintosh, et al., 2002; Ong, et al., 1995). The degraded mangroves that can no longer provide their full ecological functions and services have a social and economic cost (UNEP-WCMC, 2006) such as: (i) reduced fish catches in coastal communities; (ii) loss of export earnings and tourism revenue due to a decline in the tourism industry; and (iii) increased coastal erosion and destruction from storms and natural disasters, which impact coastal residents, tourism operations and vital economic sectors.

Since the 1990s, the growing consensus on the impacts of mangrove forest loss has led to renewed efforts to protect and restore them by governments, NGOs and local communities - to conserve, rehabilitate and manage mangroves in a more sustainable way.

Coastal areas of Viet Nam, and northern Viet Nam in particular, have always been home to an extensive mangrove ecosystem. Mangrove reforestation was initiated by the government through the Ministry for Agriculture and Rural Development (MARD) as early as the 1960s. From the 1990s, several NGOs such as Action for Mangrove Reforestation (ACTMANG), the Viet Nam Red Cross with support from the Danish Red Cross and Japanese Red Cross associations have tried to re-plant mangroves on deserted mudflats. The first attempts at replanting suffered from high losses due to low survival rates of the young plants. Later on, technical advice from scientists and increasing awareness of the importance of these coastal forests spurred further attempts to restore mangroves, engaging governments, NGOs and local communities. As a result, by 2012 , about $50 \%$ of the 41,115 ha of planted forests in the north of Viet Nam (FIPI-MARD, 2013) have brought significant benefits to local communities.

Kandelia obovata is the most common mangroves species planted in northern Viet Nam as part of several programmes/projects. These plants grow to a height of $3 \mathrm{~m}$ and 
are mature after about five years. They feature propagules - ready-to-go seedlings - that can be picked from any mature tree and planted without the need for costly purchases from nurseries. K. candel are planted with a distance of $50-70 \mathrm{~cm}$ between seedlings and form the backbone of the mangrove forests planted in this region of Viet Nam. Sonneratia caseolaris is much higher, typically growing up to $7-11 \mathrm{~m}$. In most cases, $S$. caseolaris is interplanted between $K$. candel at distances of $3 \mathrm{~m} \times 3 \mathrm{~m}$. S. caseolaris needs to be raised in nurseries before planting in the field. Rhizophora stylosa features particularly strong roots; their propagules can be collected but usually need to be cared for in nurseries before they can be planted on mudflats. $R$. stylosa is planted to further diversify mangrove forests. Thus, of those planted species, $K$. obovata is always the dominant species due to its high planting density and its ability to regenerate at a very early stage - three to five years old.

Viet Nam is situated in the tropical monsoon zone, subject to typhoons between November and April, and is one of the ten countries most prone to, and 'at risk' from, the impacts of climate change (Francisco, 2008). The impacts of climate change are felt in different provinces of Viet Nam, such as a significant recent shift in the summer and winter rains, causing prolonged dry periods as well as massive flooding. The increase in frequency and intensity of extreme weather events has attracted considerable concern from government, NGOs and local communities in the country.

The restored mangrove ecosystems have enhanced food security and livelihoods of the poor coastal inhabitants through service provisioning fisheries nurseries and habitats as well as protecting coastal communes from natural disasters (typhoons, waves). This paper describes the services derived from small-scale mangrove restoration intervention through a case study in northern Viet Nam. Although the assessment in this research could not quantify all the values of mangroves in northern Viet Nam it still serves as an example of a sustainable solution to ensuring local food security and disaster risk reduction. 


\section{Methodology and data}

The three coastal communes of Bang La, Dai Hop and Tan Thanh, in northern Viet Nam were selected as a study area (Figure 1). The benefits of mangroves were examined by comparing two different periods. The first assessment looked at 2005, when planted mangroves in the areas were not yet mature; and the second, in 2013, by which time the mangroves had generated several offspring by natural regeneration from 'mother' trees. The benefits and values of mangroves were assessed in the two periods through questioning and discussing with local authorities, managers and communities. To add depth and validity, a qualitative component was applied. A combination of quantitative and

Figure 1. Mangroves in Hai Phong, northern Viet Nam

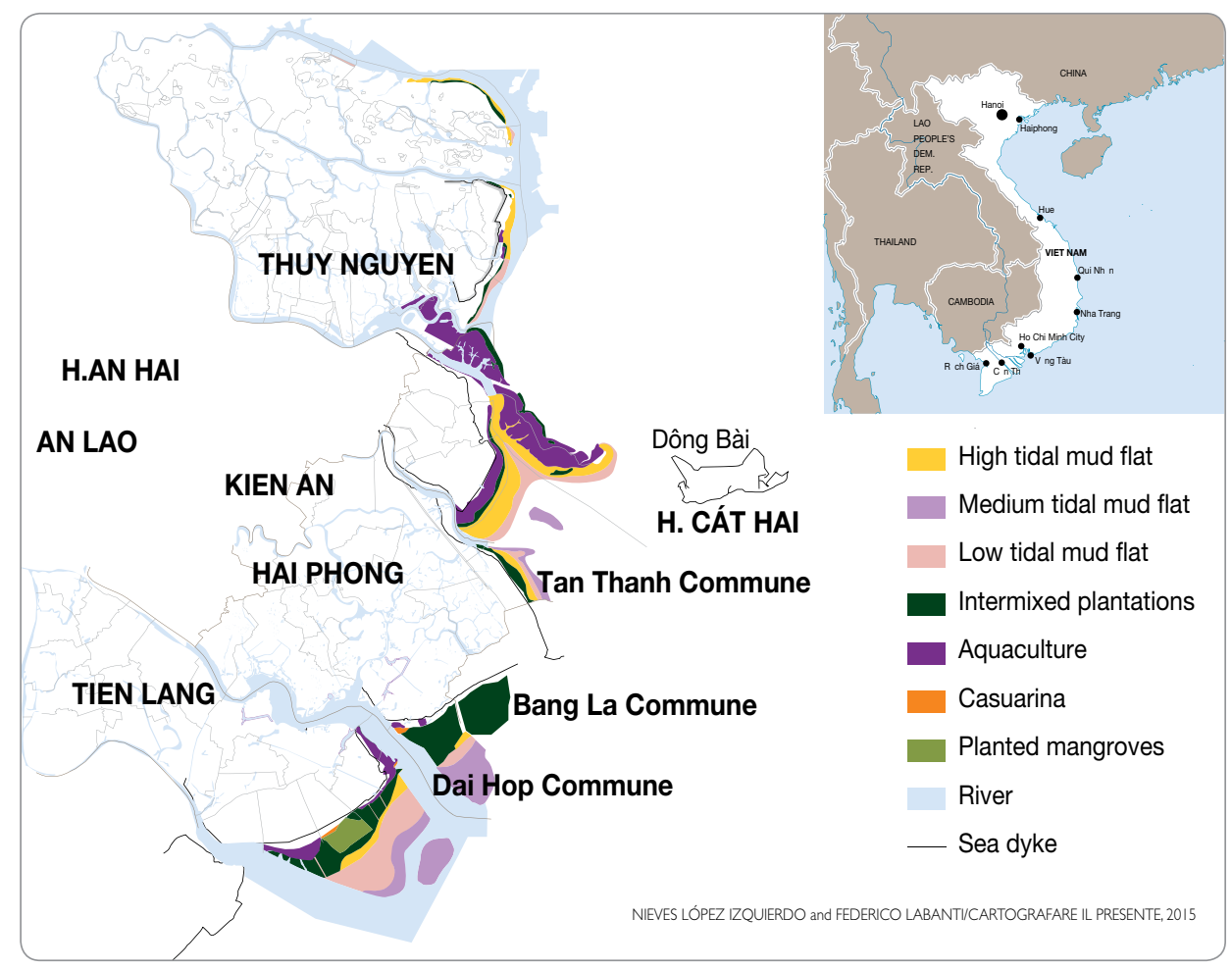

Source: Map of Viet Nam: http://www.lonelyplanet.com/maps/asia/vietnam/ 
qualitative methods was selected - a household survey and key informant interviews, focus group discussions and site visits.

In this research, 430 households were selected for sampling: $50 \%$ of the respondents were planters in mangrove plantation projects, $25 \%$ non?planters and $25 \%$ control group respondents. On average the sample size per commune was 131-150 households. The questionnaires analysed community awareness about the current status of mangroves in the area, management practices, the role of mangroves in response to climate change and the socioeconomic situation in northern Viet Nam. In addition to the questionnaire, in each commune 20 interviews with local government/leaders, association of Red Cross staff and related women's, farmers' and youth associations, school representatives, mangroves forest protection team members and some seafood catching and consumer groups were carried out.

Carbon accumulation in the mangroves was also estimated using the research results of Nguyen (2007). The amount of carbon accumulated was calculated using the formula: $y=29,766 e^{0,17 x}$.

Where: $y$ is the cumulative amount of carbon (carbon tonnes/ha) and $x$ is the stand age of planted mangrove trees.

All the qualitative and quantitative data were collected between July and September 2014. The collected data were then compiled and analysed. 


\section{The role of restored mangrove ecosystem in resilient food systems}

Mangroves offer an array of features to ameliorate the effects of extreme events such as hurricanes, tidal bores, cyclones and tsunamis (Alongi, 2008). Coastal protection was the original reason for planting mangroves in the north of Viet Nam.

The protective features of mangroves in this area were compared by studying the two level-9 typhoons (wind speed of $75-88 \mathrm{~km} / \mathrm{h}$ and mean value of wave height of $7.0 \mathrm{~m}$ ) that hit Dai Hop commune in 1987 and 2005 with similar magnitudes of wind speed and tidal levels. Dai Hop is a commune of 11,000 people located on the coastline of Kien Thuy district, Hai Phong. There are mixed Kandelia obovata, Sonneratia caseolaris and Rhizophora stylosa planted in an area of $450 \mathrm{ha}$, stretching along the entire dyke length of $3.9 \mathrm{~km}$ (and 1-1.5 $\mathrm{km}$ in width). The forest shows its maturity: being up to $4 \mathrm{~m}$ in height for $K$. obovata and up to $11 \mathrm{~m}$ in height for $\mathrm{S}$. caseolaris. In 1987, the storm caused serious damage to a $3-\mathrm{km}$ stretch of the dyke that needed to be repaired at a cost of US $\$ 300,000$. The same dyke remained totally undamaged when the storm hit the area in 2005 as it was then protected by a mangrove forest more than $1 \mathrm{~km}$ wide. The maximum damage cost from 2005 typhoons amounted to US\$ 5,000 to repair a small outer mini-dyke. The cost difference in dyke repair of US $\$ 295,000$ can be attributed to the mangrove plantation and thus this can be seen as a direct benefit of the programme. It should also be noted that over the 18 years between the storms, the mudflat was significantly expanded by up to $1 \mathrm{~km}$ (partially as a result of the higher sediment retention due to the mangroves) (IFRC, 2011).

Damage to private property was even more significantly reduced: whereas $90 \%$ of shrimp farm value had been destroyed in 1996 (when the mangrove forest had not yet been restored), only 25\% was swept away 18 years later. Furthermore, whereas paddy fields were inundated with saltwater (the existing paddies were not only destroyed but their yield was also diminished by an estimated average of $50 \%$ over four years), the same paddies remained unharmed when the sea dykes were protected by mangrove forests 18 years later. By this service, restored mangroves play a vital role in resilient food systems.

By reducing the intensity of extreme weather events such as typhoons before they reach areas of human settlement, mangroves also protect food production systems that lie further inland. 


\section{Mangrove forests and livelihoods of coastal communities}

The aquatic products within or near restored mangrove forests are a direct source of income - aquatic fishing is the most significant economic activity for local communities. The group with the largest direct income from restored mangrove forests practises aquaculture in the area. Next are beekeepers and intermediate seafood purchasers/ traders. The benefits include calculations based on the direct value of livelihood benefits, direct values that are not precisely quantified such as generating favourable conditions for aquaculture, environmental landscape, and indirect values such as dyke protection, carbon accumulation, etc.

\section{Direct benefits}

Collecting aquatic products: In the study area, collecting aquatic products within and near mangroves is the most important livelihood activity for poor households outside the main agricultral crops. The products collected are crabs, shrimp, fish, molluscs etc. they are mainly consumed in the local communities.

Results of the household survey indicated that the average income per hectare of mangrove forests in 2005 in the study area was US\$ 131-272 per month. In 2013 it was US\$ 319-498 per month. Survey results show that there are up to 200 people who undertake manual harvesting within and near the mangroves each day in each commune (Table 1), clearly demonstrating the role of the mangrove plantation in the local economy at a household level.

The results of this study can be compared with US\$370/ha - the calculation of IFRC (2011) in the coastline area of northern Viet Nam. The benefit of collecting natural aquatic products in the restored forest areas is five to eight times higher than the estimated results of that activity in the bare land areas (US\$ 75) (where there are no mangrove trees, just mud). 
Table 1.

Comparison of the benefits of collecting aquatic products inside mangrove areas in 2005 (rare and young stand of planted mangroves) and in 2013 (mature restored forest)

\begin{tabular}{|c|c|c|c|}
\hline & & Mean & Standard deviation \\
\hline \multirow{5}{*}{$\begin{array}{l}\text { Aquatic } \\
\text { products } \\
\text { collection } \\
\text { within and } \\
\text { near mangrove } \\
\text { forest (2013) }\end{array}$} & Area (ha) & 300 & 82 \\
\hline & Number of working days (day/month) & 15 & 2 \\
\hline & Number of working months (month/year) & 6 & 1 \\
\hline & Number of collectors (people/day) & 115 & 28 \\
\hline & Income per ha (US\$) & 435 & 82 \\
\hline \multirow{5}{*}{$\begin{array}{l}\text { Collecting } \\
\text { aquatic } \\
\text { products } \\
\text { within and } \\
\text { near mangrove } \\
\text { forest (2005) }\end{array}$} & Area (ha) & 210 & 57 \\
\hline & Number of working days (day/month) & 13 & 1 \\
\hline & Number of working months (month/year) & 6 & 0 \\
\hline & Number of collectors (people/day) & 89 & 38 \\
\hline & Income per ha (USD\$) & 196 & 58 \\
\hline
\end{tabular}

In addition to the results of the household survey on the role of mangroves in the livelihoods of the community, a secondary analysis of data was conducted based on the socioeconomic status of the local community as well as interviews with local authorities and relevant officials. These analyses indicate that the figures from local authorities are significantly greater than shown by the data from the survey, for example, the number of people harvesting aquatic products each day was around $30-40 \%$ greater; the number of working days was $25-35 \%$ higher; total months worked per year was 12 instead of the 6-7 months of the household survey. In Bang La the reported value of aquatic product collection was US \$2,643/ha/year (2013). This value was higher than in the survey (US\$ 435/ha/year), but is comparable with the economic efficiency of mangrove forests elsewhere in the world.

Livelihood incomes from restored mangroves in 2013 showed that local communities benefited from the increasing value of fishing activities compared with 2005. The number of people collecting aquatic products in 2013 increased 10-35\% over 2005 figures. The number of working days and working months in the year seemed stable. Regarding the quality of aquatic products, feedback on the types of fishery products changed. Noteworthy in 2013 was the large size of aquatic products, such as crabs, to be found, and some varieties of shrimps tended to be more limited than in 2005. Overall, the economic effect/labourer/ day increased from US\$ 5.90-9.30/working day in 2005 to US\$ 8.70-19.20/working day in 2013. The results of research in the planted mangroves in Giao Thuy and Nam Dinh (Hawkins, et al., 2010) showed the benefits from collection of aquatic products equivalent to US\$ 173-187/ha/year. Cabrera, et al. (1998) surveys in Hongbo, Kunchang and Yongchong Daebu-do-do (South Korea) showed values of natural fisheries (including animals and plants 
- algae and sea grass) of US\$ 8,400-10,600/ha/year. The results of integrated data from Asia (Ronnback, 1999) indicate income from fishing of US\$ 750-1,128/ha of mangrove/year. Socioeconomic values of mangrove ecosystems in Ban Naca and Ban Bangman in Ranong Province, Thailand, displayed that the value per hectare of mangroves/year for mangrove fish, crustaceans, molluscs and forest products ranged from US\$1,336-6,012/ha/year.

Additionally, around 10-20 households in each village generate their main income by buying collected aquatic products from collectors and then selling those products to markets or other buyers/traders.

Bee raising: Beekeeping is a seasonal economic activity and mostly benefits a small number of people in mangrove areas in general and in northern Viet Nam in particular. Depending on the total area of mangroves, in the flowering season, in each commune, there are 200-500 hive stands. Approximately 5 I of honey are harvested from one hive stand/ year with each litre of honey equivalent to US\$ 7.50-9.50. In total, each year, beekeeping in the study area generates US\$ $45 /$ ha/year. This figure is $6-7$ times higher than the surveys conducted by Hawkins, et al. (2010) in Nam Dinh. The different figures in the two locations can be explained by the distribution of mangrove vegetation in the study area which is close to sea dykes, and more favourable for bee-raising activities.

The direct benefits of livelihoods (such as natural fishing) from restored mangrove areas are equivalent to US\$435-2,643/ha/year with the beekeeping being worth about US\$ 45 / ha/year.

\section{Indirect benefits}

Accumulation of carbon: As explained in the introduction, in the study area, the dominant species is $K$. obovata and planted vegetation ranged in age from 6 to 14 years old (having been planted in 1998-2007). The carbon accumulated in the mangrove forest in the study site is calculated mainly based on $K$. obovata plantation. Table 2 presents the stand age of the vegetation in the study area and relative quantification of carbon accumulation in the soil and mangrove trees.

In terms of the ecological benefits, up to 2013, the amount of carbon sequestration by mangroves in the study area was estimated to be 295,433 tonnes - equivalent to $1,083,291$ tonnes of $\mathrm{CO}_{2}$. With the price of US\$37/tonne of $\mathrm{CO}_{2}$ (World Bank, 2014), restored mangroves in the areas can generate US\$ 40,081,768 (their carbon storage value for the entire region) or US $\$ 44,535 / h$. Thus, in the context of coping with climate change, mangroves act as a climate change mitigation measure and as a place for carbon accumulation. 
Table 2. Above and below ground carbon accumulation in the planted mangroves in the study area up to the year 2013 (mainly K. obovata, the dominant species)

\begin{tabular}{ccccc} 
Planting year & Stand age (years old) & Area (ha)* & Carbon/ha & Total carbon (tonnes) \\
\hline 2007 & 6 & 18 & 82.56 & 1,486 \\
\hline 2006 & 7 & 18 & 97.83 & 1,761 \\
\hline 2005 & 8 & 18 & 116.00 & 2,088 \\
\hline 2004 & 9 & 18 & 137.44 & 2,474 \\
\hline 2003 & 10 & 36 & 162.94 & 5,866 \\
\hline 2002 & 11 & 36 & 193.14 & 6,953 \\
\hline 2001 & 12 & 36 & 228.92 & 8,241 \\
\hline 2000 & 13 & 90 & 271.33 & 24,420 \\
\hline 1999 & 14 & 180 & 321.62 & 57,891 \\
\hline 1998 & 15 & 270 & 381.21 & 102,928 \\
\hline 1997 & 16 & 180 & 451.86 & 81,334 \\
\hline Total & & 900 & & $\mathbf{2 9 5 , 4 4 3}$ \\
\hline
\end{tabular}

Notes: * Data from the Forestry Department (2013).

Other values: Mangroves provide nutrition and habitats for aquaculture activities. Although a quantitative analysis of this aspect was not undertaken by the study, the evaluation of the planted mangroves in Giao Thuy, Nam Dinh by Hawkins (2010) shows a value of US\$ 882-980/ha/year for providing nutrition and habitats for aquatic organisms.

Medicinal plants were commonly used for medicine locally. This service provided little in terms of economic value (US\$1-2/ha/year) (Hawkins, 2010) but had cultural value in the community.

The indirect benefits of mangroves in the study area include the value of carbon accumulation of US $\$ 44,535 /$ ha, providing nutrition and habitats for aquatic organisms valued at US\$ 882-980/ha/year and about US\$1-2/ha/year for medicinal plants.

Natural resource harvesting - crabs, shrimp, shellfish collection, beekeeping - in mangrove areas is very common in the study area. In several villages in northern Viet Nam, a reported $70-90 \%$ of the population rely on natural resource exploitation in mangroves for income. They are mainly poor women. Natural resource use in mangrove forests is important to local people due to limited availability of agricultural land, especially given the rapidly increasing population, and there are also off-farm income opportunities. Over the past decade, as the importance of mangroves has come to be more widely recognized in Viet Nam, various management approaches, which may be used independently or as part of an integrated strategy, have emerged to promote mangrove conservation and restoration. The success of mangrove conservation in Viet Nam will ultimately depend on integrating development and conservation goals. 


\section{Conclusion}

Although the assessments in this research could not quantify all the values of mangroves in northern Viet Nam, this study indicated clear evidence that people's day-today livelihoods have been enhanced through small-scale restored mangroves. Results also demonstrated the importance of restored mangroves in coastal protection and support for local communities. It is clear that the restored mangrove ecosystem provides food resources and income for local people. In particular the life of poor women is enhanced and stabilized as a result of aquatic products collection, honeybee raising etc. Mangrove restoration in northern Viet Nam can act as habitat development and coastal protection, decreasing coastal vulnerability to extreme events. Through this service, restored mangroves play an important role in resilient food systems, which significantly contribute to food security.

In the context of coping with climate change, restored mangroves act both as climate change adaptation and mitigation measures and as the place for carbon accumulation and coastal protection. 


\section{References}

Alongi, D.M. (2008). 'Mangrove forests: resilience, protection from tsunamis, and responses to global climate change'. Estuarine, Coastal and Shelf Science 76:1-13.

Alongi, D.M. (2009). The Energetics of Mangrove Forests. New York: Springer Science, 216pp.

Cabrera, M.A., Seijo, J.C., Euan, J. and Pérez, E. (1998). 'Economic Values of Ecological Services from a Mangrove Ecosystem'. International newsletter of coastal management 32. Narragansett, Rhode Island, USA.

FIPI-MARD (2007). Report on 'Results of review and planning of coastal protection forests' (in Viet Namese). Hanoi, Viet Nam: Forest Inventory and Planning Institute-Ministry for Agriculture and Rural Development.

FIPI-MARD (2013). Report on 'Results of review and planning of coastal protection forests' (in Viet Namese). Viet Nam: Forest Inventory and Planning Institute-Ministry for Agriculture and Rural Development.

Francisco, H.A. (2008). Adaptation to Climate Change Needs and Opportunities in Southeast Asia. Economy and Environment Program for Southeast Asia (EEPSEA).

Giesen, W., Wulffraat, S., Zieren, M. and Scholten, L. (2007). Mangrove guidebook for Southeast Asia. Bangkok, Thailand: Food and Agricultural Organization and Wetlands International, 770pp.

Hawkins, S., et al. (2010). Roots in the water. Legal frameworks for mangrove PES in Viet Nam. Katoomba Group's Legal Initiative Country Study Series. Washington, DC: Forest Trends and the Katoomba Group.

Hogarth, P.J. (1999). The Biology of Mangroves. Oxford, UK: Oxford University Press, 228pp.

Hong, P.N. and San, H.T. (1993). Mangroves of Viet Nam. Gland, Switzerland: IUCN.

Hong, P.N. (1991). The Ecology of Mangrove Vegetation of Viet Nam (in Viet Namese). Hanoi National University, doctoral dissertation, 357pp.

IFRC (2011). Planting protection: Evaluation of community-based mangrove reforestation and disaster preparedness programme, 2006-2010. Geneva, Switzerland: International Federation of Red Cross and Red Crescent Societies.

Macintosh, D.J., Ashton, E.C. and Havanon, S. (2002). 'Mangrove rehabilitation and intertidal biodiversity: A study in the Ranong mangrove ecosystem Thailand'. Estuarine Coastal and Shelf Science 55:331-345.

Maurand, P. (1943). L'Indochine forestiere. Hanio, Viet Nam: d'Extreme Orient.

Millennium Ecosystem Assessment (2005). Ecosystems and Human Well-being: Synthesis. Washington, DC: Island Press.

Mitsch, W.J. and Gosselink, J.G. (2007). Wetlands (4th ed.). New York: Wiley, 582pp.

Nguyen T.K.C and Sinh, T.H. (2007). Stand structure and carbon accumulation process in mangrove forests in Thai Binh River Mouth, Northern Viet Nam. Dissertation. Faculty of Agriculture, Ehime University, Japan.

Ong, J.E. (1993). 'Mangroves - a carbon source and sink'. Chemosphere 276:1097-1107. 
Ong, J.E., Gong, W.K. and Clough, B.F. (1995). 'Structure and productivity of a 20-year-old stand of Rhizophora apiculatamangrove forest'. Journal of Biogeography 22:417-424.

Ronnback, P. (1999). 'The ecological basis for economic value of seafood production supported by mangrove ecosystems'. Ecological Economics 29:232-252.

Tri, N.H., Adger, W.N. and Kelly, P.M. (1998). 'Natural resource management in mitigating climate impacts: the example of mangrove restoration in Viet Nam'. Global Environmental Change 81:49-61.

UNEP-WCMC (2006). In the front line: Shoreline protection and other ecosystem services from mangroves and coral reefs. Cambridge, UK: United Nations Environment Programme-World Conservation Monitoring Centre, 33pp.

World Bank (2014). State and Trends of Carbon Pricing 2014. Washington, DC: World Bank. 


\section{Restoring degraded forest landscape for food security:}

\section{Evidence from cocoa}

agroforestry systems, Ghana

Isaac Nunoo, ${ }^{1,3}$ Beatrice Obiri Darko² and Victor Owusu ${ }^{3}$

1 Rural Education and Agriculture Development International, Kumasi, Ghana

2 Forestry Research Institute of Ghana

3 Kwame Nkrumah University of Science and Technology, Kumasi, Ghana 


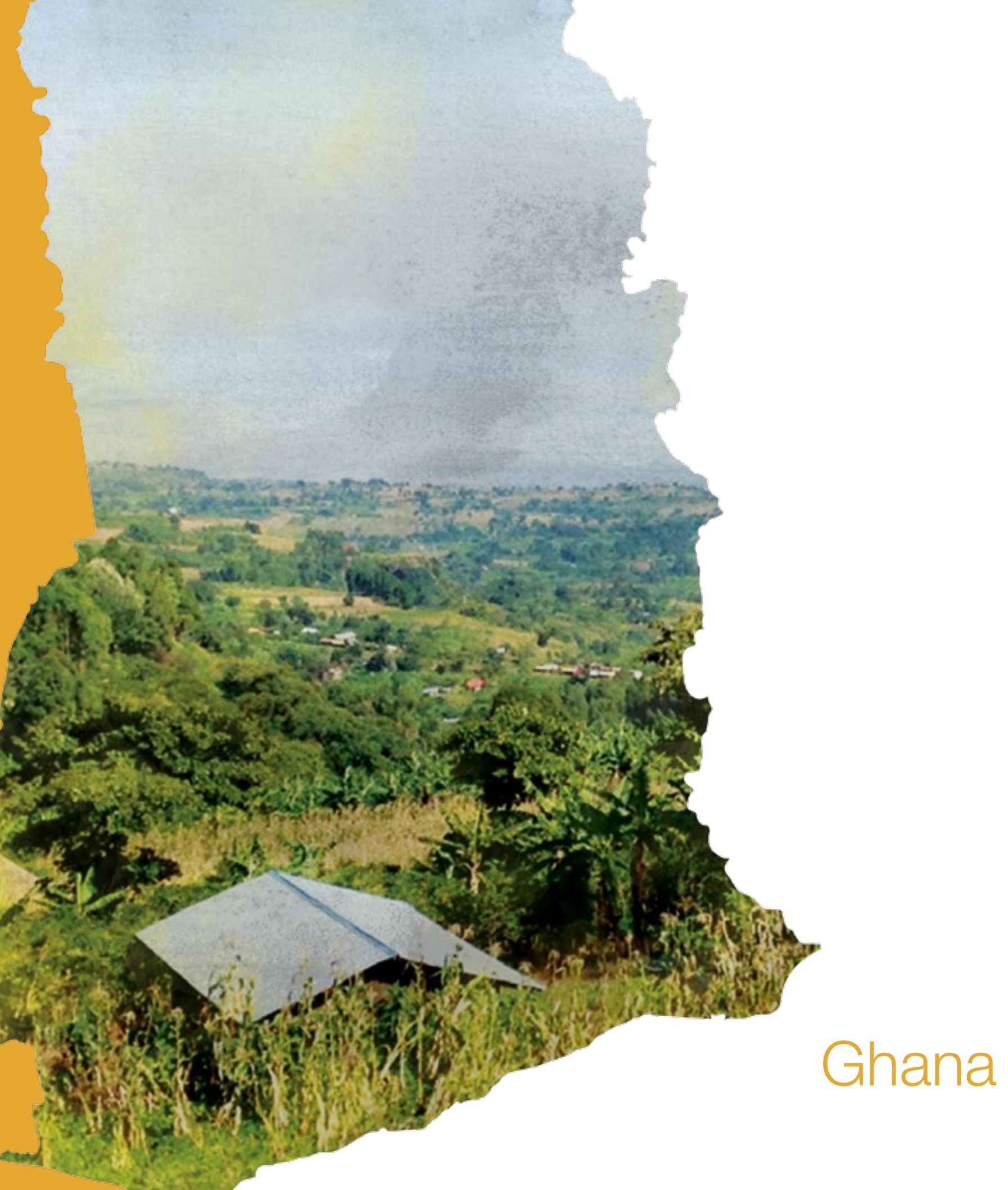




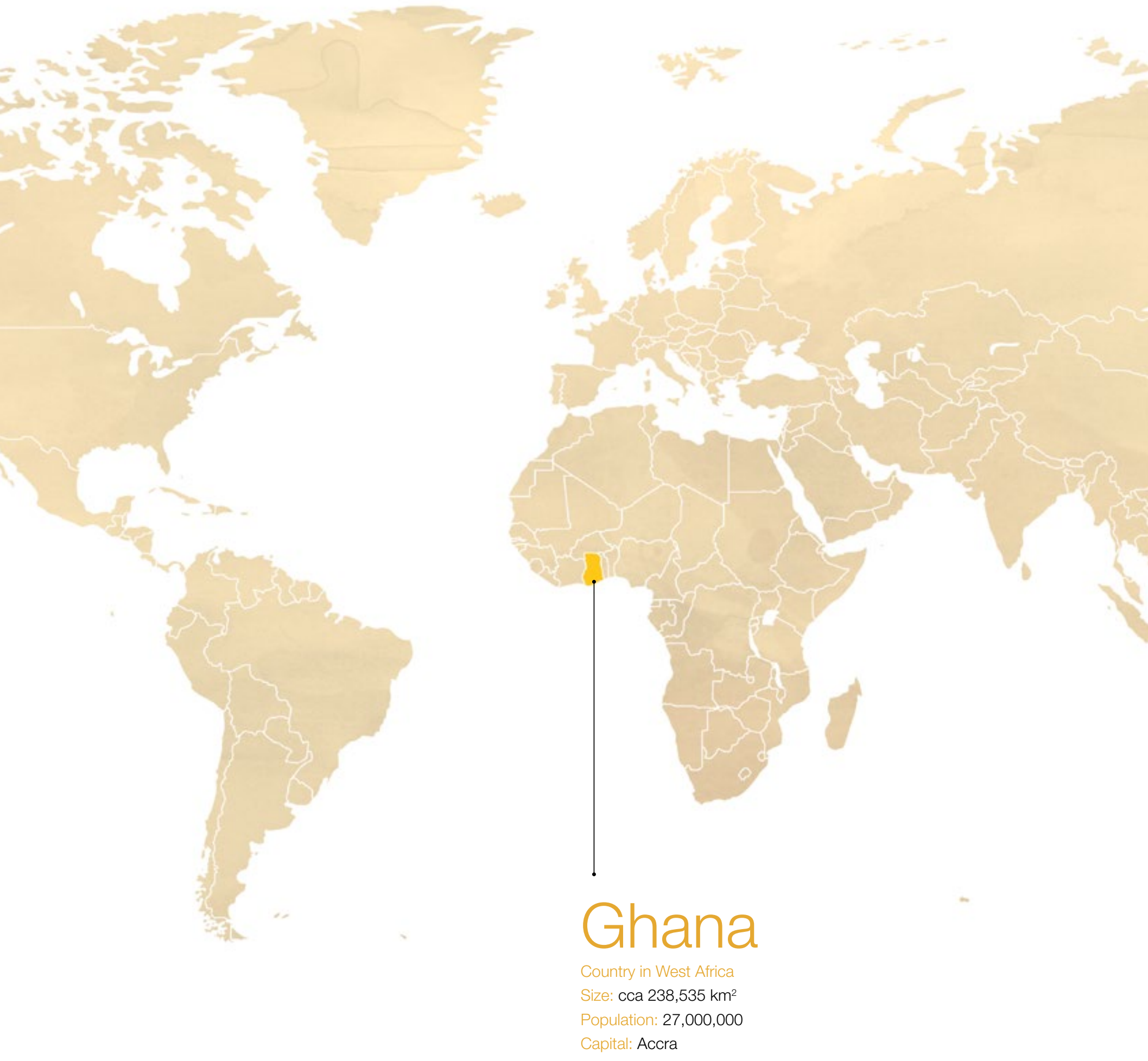




\section{Introduction}

Worldwide, cocoa production employs over 15 million people of which 1.39 million are in the Americas and 3.61 million in Asia. The remaining majority of 10.5 million workers are in West Africa, which produces more than $70 \%$ of the world's cocoa (de Lattre-Gasquet, et al., 1998). Cocoa production is an essential component of rural livelihoods and its cultivation is considered a 'way of life' in rural communities. In Ghana, the cocoa sector employs over 800,000 smallholder farm families and contributes around US $\$ 2$ billion in foreign exchange - 85\% of foreign export earnings (ISSER, 2013).

Cocoa (Theobroma cacao L.), which is traditionally a shade loving plant, is mostly intercropped with several high value tree species in addition to other crops (Duguma, et al., 2001). Cocoa agroforestry is seen to be a sustainable practice that combines forestry and agriculture, making it one of the most promising strategies to increase food production without additional deforestation. The interaction of cocoa and trees offers farmers a range of agronomic, economic, cultural and ecological benefits. Agroforestry systems have experienced a surge in interest from the research and development communities, as a cost-effective means to enhance food security, while at the same time contributing to climate change adaptation and mitigation in the wake of recurring food shortages (Mbow, et al., 2014). According to Thorlakson, et al., (2012) integrating shade trees and crops reduced food insecurity during drought and flooding in western Kenya by $25 \%$. Trees on farms provide both products and services: they yield food, fuelwood, fodder, timber and medicines, and they replenish organic matter and nutrient levels in soils and assist with erosion control and water conservation. Trees in cocoa agroforestry systems improve tree cover and improve connectivity between the cocoa agricultural landscapes and forest landscapes, thereby improving biodiversity and enhancing productivity.

Cocoa agroforestry systems can help millions of people escape poverty and prevent environmental degradation. Tree canopies can create a more adequate microclimate for crops and more resilient ecosystems for better food production. The system can be regarded as a win-win practice as it can support food security, mitigate climate change and contribute to adaptation to these changes. In addition, cocoa agroforests play a significant role in carbon sequestration. In the humid forest zone of Cameroon, cocoa plantations conserve $62 \%$ of the carbon of the primary forest (Kotto-Same, et al. 1997). A plant biomass of $304 \mathrm{t} / \mathrm{ha}$ was found in cocoa plantations, as compared with $85 \mathrm{t} / \mathrm{ha}$ in food crop 
fields and 541 t/ha in primary forest (Duguma, et al. 1998). Recently an increasing number of studies have advocated the benefits of cocoa agroforestry systems. Higher densities of shade trees may prolong the agronomic sustainability of these systems through processes of nutrient cycling associated with litter fall (Afari-Sefa, 2010), while agroforestry practices as a whole help provide natural predators and parasites for improved pest control (Obiri, et al., 2007). 


\section{Deforestation - a critical environmental issue}

Many parts of Africa continue to experience food insecurity, declining per capita farm income and land and soil degradation and, according to Vlek, et al. (2010), Ghana is no exception. According to the Food and Agriculture Organization of the United Nations (FAO), $21.7 \%$ of land in Ghana (equivalent to $4,940,000$ hectares) is covered by forest (FAO, 2010). Deforestation has been identified as a critical environmental issue and Ghana has lost more than $33.7 \%$ of its forests, equivalent to $2,500,000$ hectares, since the early 1990 s (FAO, 2010). Between 2005 and 2010, the rate of deforestation was estimated at 2.19\% per annum; the sixth highest deforestation rate globally for that period (FAO, 2010). The total area under cocoa cultivation increased by 50,000 hectares (to 1,650,000 hectares) between 2012 and 2013 (MoFA-SRID, 2014). The annual increase in cocoa farm size is recognized to be one of the major factors contributing to the high rates of deforestation in Ghana (Ministry of Science and Environment, 2002).

Until 2002, the tree tenure right and benefit sharing system discouraged cocoa farmers from retaining valuable trees on their farms. The Forestry Services Division (FSD) receives 60 percent of the total stumpage and rent collected; the office of the administrator of stool lands receives 10 percent; and the remaining 30 percent is divided as follows: 55 percent to the district assembly; 20 percent to the traditional council; 25 percent to the stool landowner (Boakye, K.A. and Baffoe, K.A. 2007). Cocoa farmers had no legal rights either to harvest the timber trees they maintained on their farms or to any of the revenue accruing from timber stumpage and rent. This discouraged the practice of retaining valuable trees on cocoa fields as most farmers destroyed such trees to avoid the risk of uncompensated damage caused to their cocoa trees during timber harvesting. Currently for greater incentive for sustainable forest management farmers are the owners of forest plantation products, and the Forestry Commission, landowners and forest-adjacent communities are shareholders. Although this provide some amount of financial incentive for cocoa farmers to retain timber tree species, further policy reforms have been recommended to ensure equitable benefit flows to entice farmers to retain and plant trees on their cocoa farm land (Bamfo, 2003; Obiri, et al., 2007). 
Rich natural forest is rapidly giving way to cocoa farms making it both a direct and indirect driver, of deforestation through progressive conversion of natural forests into cocoa fields. In the 2010-2011 cocoa production seasons, Ghana recorded an unprecedented production level of $1,024,600$ tonnes (MoFA-SRID, 2014). Policy makers may be congratulating themselves on the rise in cocoa output over the years, however, according to Baah, et al. (2009), it is quite apparent that degradation of current cocoa landscapes and dwindling forests for new planting create a great bottleneck to future cocoa output, sustainable livelihoods and, hence, food insecurity. Cocoa yield is very sensitive to rainfall, temperature and sunlight. The moist micro-environment in which cocoa thrives is being lost due to the clearing of shade trees on cocoa farms (Ruf \& Zadi, 1998) affecting yield. Most new cocoa planting in Ghana has been in the western region where approximately $80 \%$ has been established without shade trees or less than 10\% canopy cover (Katoomba Group, 2009). This current trend, of planting cocoa without shade trees, is making cocoa and other related farming systems unproductive and degraded over time. Thus, the system is making the long-term future of the remaining forest cover and farmers' livelihoods uncertain.

The four key research questions addressed in this paper are:

- What are the perceptions of cocoa farmers of cocoa agroforestry systems?

- What are the cocoa yield trends under the different cocoa agroforestry shade levels?

- What factors influence smallholder cocoa farmers' decision in adopting cocoa agroforestry systems?

- What is the agrochemicals usage under the different cocoa agroforestry shade levels? 


\section{Objectives of the study}

The main objective of the study is to providing empirical evidence on the land restoration potential of cocoa agroforestry systems on degraded land in Ghana.

The specific objectives are to:

- Assess the level of awareness and perception of farmers regarding cocoa agroforestry systems;

- Obtain cocoa yield trends under the different shade levels in Ghana;

- Identify specific factors that influence farmers' decision making in adopting a cocoa agroforestry system; and

- Determine agrochemicals usage under the different cocoa agroforestry shade levels.

This paper goes on to discuss the need for research, the methodology of the study, the data employed and the results. The final section presents some concluding remarks and policy recommendations. 


\section{Justification of the study}

Adoption of agroforestry depends on many factors such as access to information on agroforestry, training opportunities, good quality seeds, property rights on land, size of available land, flexibility and compatibility of agroforestry to existing farming systems. Cocoa agroforestry systems are sustainable if fully adopted and have the potential to improve food security, reduce the rampant environmental degradation and restore degraded landscapes. However adoption of agroforestry among smallholder farmers has generally been slow and has not attracted much attention from planners and development professionals (Kumar, 2006).

Socioeconomic and biophysical interactions greatly affect farmers' decisions in readily adopting some technologies, for example, more than others. One of the reasons why some agroforestry development projects failed was lack of attention to socioeconomic issues in the development of such systems (Mercer \& Miller, 1998). Economic considerations and short-term profitability alone have not fully explained farmers' adoption behaviours. Rather, adoption decisions appear to be guided by level of household resource endowments and the prevailing social context such as customs, obligations and beliefs which are highly affected by factors such as farmers' education, age and family size (Haggblade, et al., 2004). Socioeconomic studies need to focus on better understanding of local bottlenecks in achieving desired adoption rates of cocoa agroforestry systems. Understanding farmers' decision making processes in ensuring food security and supporting landscape restoration interventions is critical. Research frontiers in cocoa agroforestry systems need to identify and better understand barriers to adoption and development of strategies to support landscape restoration intervention that enhance food security. 


\section{Case study area}

This research focused on Sefwi Wiawso district in the western region of Ghana. The district was selected because it is among the highest cocoa producing districts in the country. Cocoa agroforestry technologies have been introduced in the study areas by the International Institute of Tropical Agriculture (ITTA) under the Sustainable Tree Crop Program (STCP). Also the district faces increasing deforestation as a result of cocoa extensification.

The district is one of the 18 in the western region of Ghana. It lies within latitudes $6^{\circ}$ $00^{\prime}$ and $6^{\circ} 30$ north and longitudes $2^{\circ} 15^{\prime}$ and $2^{\circ} 45$ west, with an area of 2,634 km². The vegetation is mostly moist semi-deciduous rainforest in the northern part, but turns into secondary forest farther south, mainly due to human activities such as tree felling and farming. The district has several timber species and other NTFPs like rattan and bamboo. It also abounds in game and wildlife all of which offer opportunities to generate resources for development.

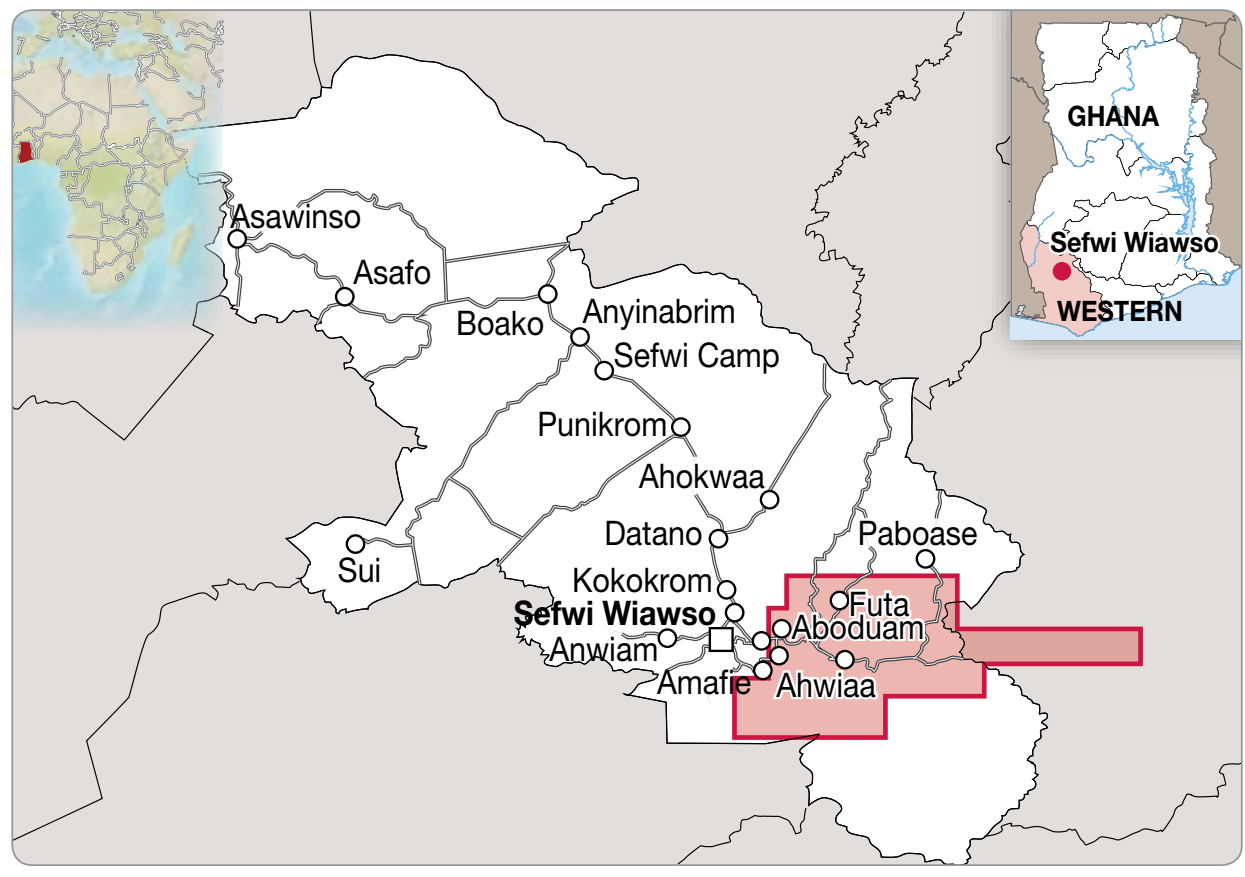

Figure 1.

The survey communities in Sefwi Wiawso 
Sefwi Wiawso district has recorded a mean monthly temperature range of $31^{\circ} \mathrm{C}$ to $33^{\circ} \mathrm{C}$ occurring within the months of February to March prior to the commencement of the rainy season. From July to August the weather is relatively cold with a mean monthly temperature of $19^{\circ} \mathrm{C}$ to $210^{\circ} \mathrm{C}$. The district falls within the higher rainfall belt of Ghana and has double rainfall peaks. It experiences an annual average rainfall of 1500-1800 mm and most soils are loamy supporting a variety of crops. The topography, which is generally undulating, makes it possible for the people to cultivate a variety of crops. It thus presents an opportunity for farmers in the district to increase their income levels through commercial farming and thus reduce poverty among households. Major staple crops grown include cassava, cocoyam, plantain, yam and maize. Cocoa is the main cash crop. While there are a few large cocoa farms and oil palm plantations, small-scale agriculture is predominantly practised in the district.

According to the 2010 population and housing census report, the Sefwi Wiawso district has a total population of 139,000 comprising 69,753 males and 69,417 females representing $50.2 \%$ and $49.8 \%$ respectively (Ghana Statistical Service, 2012). The annual growth rate is estimated to be $2.9 \%$.

The local economy in the study areas is made up of agriculture, industrial/manufacturing and services. The industries are basically small scale in nature and could be grouped into the following broad areas, agro-, wood- and metal-based. The service economy is made up of both the informal and formal economies. The informal economy comprises hairdressers, barbers, drivers, painters, market traders etc. The formal sector is made up of the financial institutions and government firms.

A total of five communities were randomly selected from the district and 40 smallholder cocoa farmers were randomly selected from each of these five communities. Primary data were obtained through structured interview questionnaires, focus group discussions and field observations. Additional data were obtained from statistical yearbooks and various related sources. Research data were collected from April to May 2012 as part of graduate research.

The respondents were stratified into four categories; no shade (full sun), low shade, medium shade and heavy shade: base on the number of shade trees and percentage canopy cover.

\begin{tabular}{|c|c|c|c|c|c|}
\hline \multirow{3}{*}{$\begin{array}{l}\text { Cocoa agroforestry } \\
\text { systems in Ghana }\end{array}$} & & No shade & Low shade & Medium shade & Heavy shade \\
\hline & No of trees/ha & No tree & $1-9$ & $10-15$ & $>15$ \\
\hline & $\%$ canopy cover & $<36$ & $36-65$ & $66-85$ & $>85$ \\
\hline
\end{tabular}

Source: UNDP, 2011; Seeberg-Elverfeldt, et al., 2009. 


\section{Conceptual and analytical framework}

The decisions to adopt various methodologies by cocoa farmers are influenced by a range of factors, from government policies, technological change, market forces, environmental concerns, demographic factors, institutional factors and delivery mechanisms. The logistic regression model which was used as the dependent variable is categorical. The model includes probit and logit - probabilistic dichotomous choice qualitative models.

Logit and probit models yield similar parameter estimates and it is difficult to distinguish them statistically. Probit models lack flexibility in that they do not easily incorporate more than one prediction variable unlike logit models. As such, probit models are less widely used in limited dependent variables. Logistic and cumulative normal functions are very close in the mid-range, but the logistic function has slightly heavier tails than the cumulative normal function (Maddala, 1983). The logit model was used in this study.

The adoption decision by farmers is specified as: $\boldsymbol{Y}=\boldsymbol{f}(\boldsymbol{X}, \boldsymbol{e})$ where $\boldsymbol{e}$ is the stochastic disturbance term assumed to follow a logistic distribution.

The logit model is generally specified as follows:

$$
\operatorname{Pr}\left(D_{t}=1 / X\right)=\Delta\left(x^{\prime} \beta\right)=\frac{e^{x^{\prime} \beta}}{1+e^{x^{\prime} \beta}}
$$

Where $\boldsymbol{D}_{\boldsymbol{t}}$ denote a dummy variable equal to $\mathbf{1}$ if household $\boldsymbol{i}$ adopts cocoa agroforestry systems (CAS) and 0 otherwise; $\boldsymbol{\beta}$ is a vector of parameters to be estimated; $\boldsymbol{x}$ is defined as a vector of the covariates that are postulated to affect adoption of CAS and $\Delta$ is a logistic cumulative distribution function (CDF). The logit model is estimated by maximum likelihood (ML), assuming independence across observations and that the $\mathrm{ML}$ estimator of $\boldsymbol{\beta}$ is consistent and asymptotically normally distributed. However, the estimation rests on the strong assumption that the latent error term is normally distributed and homoscedastic. The maximum likelihood estimate is the value of the parameter that is most consistent with the observed data in that if the parameter equalled that estimate, the observed data would have a greater chance of occurring than if the parameter equalled any other possible value. 


\section{Results and discussion}

\section{Socioeconomic characteristics}

Descriptive statistics of variables examined in the study are presented in Table 2. The average age of cocoa farmers was 46 years, close to the national average age for cocoa farmers in Ghana of 50 years (Ghana Statistical Service, 2012). About 85\% of the cocoa farmers were male. The predominant activities of cocoa farming such as pesticide, fungicide and fertilizer application as well as epiphyte removal are mostly done by men. The mean year of schooling of cocoa farmers is nine years, which is below the national average of 15 years for universal and compulsory basic education.

Table 2.

Variable definition and descriptive statistics

\begin{tabular}{|c|c|c|c|c|c|c|c|}
\hline \multirow[b]{2}{*}{ Variable } & \multirow[b]{2}{*}{ Variable definition } & \multicolumn{2}{|c|}{ CAS adopters } & \multicolumn{2}{|c|}{ CAS non-adopters } & \multicolumn{2}{|c|}{ Total sample } \\
\hline & & Mean & $\begin{array}{l}\text { Standard } \\
\text { deviation }\end{array}$ & Mean & $\begin{array}{l}\text { Standard } \\
\text { deviation }\end{array}$ & Mean & $\begin{array}{l}\text { Standard } \\
\text { deviation }\end{array}$ \\
\hline $\begin{array}{l}\text { Adoption } \\
\text { of CAS }\end{array}$ & $\begin{array}{l}\text { Adoption of CAS } \\
\text { dummy }=1 \text { if } \\
\text { household adopted } \\
\text { CAS, } 0 \text { otherwise }\end{array}$ & & & & & & \\
\hline
\end{tabular}

\section{Explanatory variables}

\begin{tabular}{|c|c|c|c|c|c|c|c|}
\hline GENDER & 1 if male, 0 otherwise & 0.87 & 0.33 & 0.76 & 0.431 & 0.85 & 0.363 \\
\hline HHSIZE & Household size & 6.81 & 2.62 & 6.12 & 2.23 & 6.64 & 2.548 \\
\hline FAMORG & $\begin{array}{l}1 \text { if farmer is a } \\
\text { member of farmers' } \\
\text { organization, } 0 \\
\text { otherwise }\end{array}$ & 0.41 & 0.49 & 0.18 & 0.388 & 0.36 & 0.480 \\
\hline EXTSERV & $\begin{array}{l}1 \text { if access to } \\
\text { extension services, } 0 \\
\text { otherwise }\end{array}$ & 0.75 & 0.43 & 0.51 & 0.50 & 0.69 & 0.464 \\
\hline COCVAR & $\begin{array}{l}1 \text { if farmer grows } \\
\text { hybrid, } 0 \text { otherwise }\end{array}$ & 0.54 & 0.50 & 0.96 & 0.198 & 0.64 & 0.480 \\
\hline AGE & $\begin{array}{l}\text { Age of respondent } \\
\text { (years) }\end{array}$ & 46.16 & 13.00 & 45.14 & 12.90 & 45.90 & 12.952 \\
\hline EDUC & $\begin{array}{l}\text { Years of schooling } \\
\text { (years) }\end{array}$ & 9.4 & 2.22 & 7.8 & 2.169 & 9.0 & 2.210 \\
\hline FMSIZE & Farm size (ha) & 2.27 & 1.28 & 2.45 & 1.82 & 2.32 & 1.43 \\
\hline CASTRAIN & $\begin{array}{l}1 \text { if farmer has had } \\
\text { training in CAS, } 0 \\
\text { otherwise }\end{array}$ & 0.32 & 0.46 & 0.06 & 0.23 & 0.26 & 0.43 \\
\hline
\end{tabular}


The average cocoa farm size was 2.3 hectares, which is relatively lower than the national average of 3.0 hectares for small-scale farmers. The study demonstrates that $25 \%$ of cocoa landscapes in the region are without trees on their cocoa farms (no shade), relatively lower compared with the $28 \%$ indicated by UNDP (2011). Further analysis showed that $37.5 \%$ of cocoa landscape is characterized by low shade, $22.5 \%$ medium shade and $15 \%$ heavy shade. This confirms Katoomba Group's (2009) finding that most new cocoa planting in the western region has been established without shade trees.

\section{Farmers' perceptions of CAS as a landscape restoration intervention and strategy for food security}

Almost all the respondents (98\%) indicated that CAS have strong potential in addressing problems of food insecurity and degraded lands in Ghana and other cocoa growing countries. The respondents further stated that proper combination of shade trees, cocoa and crops would allow producers to make the best use of their land, boost field crop yields, diversify income and increase resilience to climate change.

About $78 \%$ of the cocoa farmers are aware of CAS and $34 \%$ had actually attended a workshop on how to integrate shade trees into cocoa farming to enhance benefits. The majority of the cocoa farmers (96\%), however, have positive attitudes toward the use of shade trees on their cocoa farms, probably due to the fact most of them had 20 years' experience in cocoa farming. In Figure 1, about $85 \%$ of respondents shared the view that CAS promote sustainable yield in cocoa and increase income while $12 \%$ disagreed with this assertion. The access to additional food at markets depends on the level of cash income and purchasing power of the people. The incomes accrued from the sale of cocoa constitute the principal source of cash income and food purchasing power of the majority of the cocoa farmers in the study region.

All respondents indicated that CAS mitigate global warming by creating micro-climatic environments favourable for crop production as well as enhancing soil fertility. One of the major potential benefits of shade trees on cocoa farms is their ability to replenish nutrientdepleted soil. Related to this, almost 90\% agreed that cocoa agroforestry enhances soil fertility. Intercropping trees within a cropland, the trees circulate nutrients from deeper layers in the soil through their root system and the tree. Almost 95\% of respondents indicated that the presence of Gliricidia sepium in particular is effective at drawing nitrogen from the air and fixing it in the soil, reducing the need for large doses of manufactured nitrogen fertilizers. The leaves shed by the trees replenish the soil, increasing its structural stability and capacity to store water, which supports other food crops. Different rooting systems among diverse trees in cocoa agroforests help overlap significantly and the resultant higher root-length density may reduce nutrient leaching. 
Figure 2.

Perception of cocoa farmers on cocoa agroforestry for ensuring food security

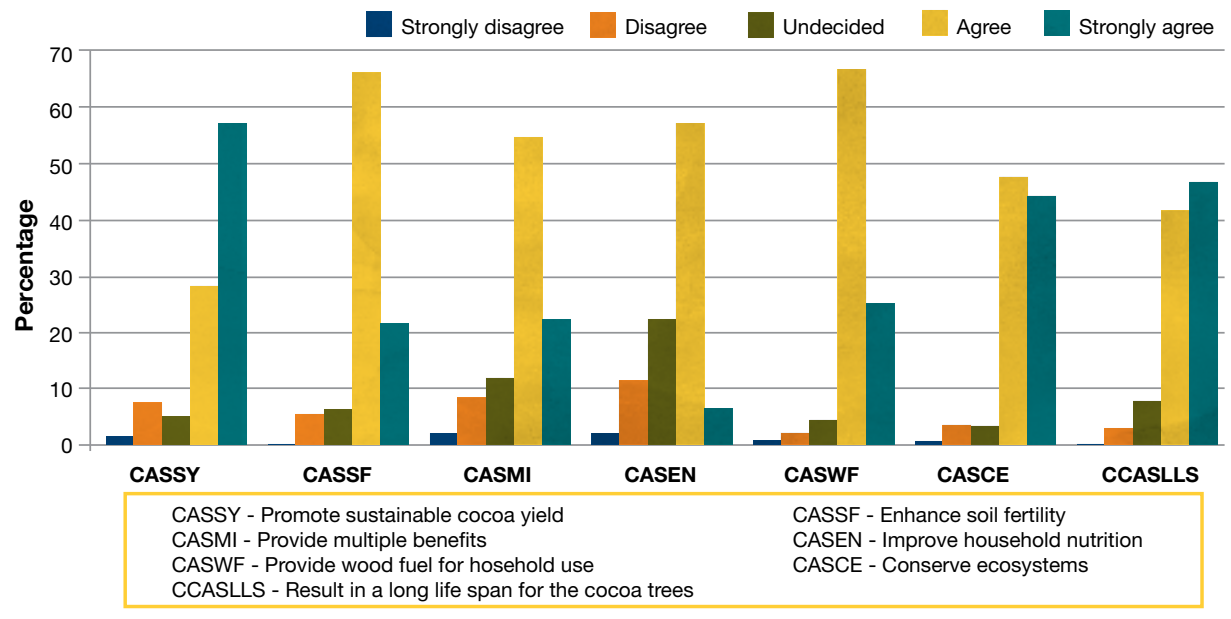

Notes: the following abbreviations denote the perception of cocoa agroforestry to: CASSY - promote sustainable cocoa yield; CASSF - enhance soil fertility; CASMI - provide multiple benefits; CASEN - improve household nutrition; CASWF - provide wood fuel for household use; CASCE - conserve ecosystems; and CCASLLS - result in a long life span for the cocoa trees.

Source: field survey (2012).

Cocoa agroforestry systems raise and stabilize farm incomes according to $75 \%$ of respondents. Direct benefits from CAS are in the form of food products, which include edible fruits, nuts, grain, rhizomes and tubers, leaves, flowers, fodder, mushrooms, medicinal plants and game. The diverse products, which are available all year round in CAS, do not only contribute to food security during the lean seasons but also ensure food diversity. According to respondents (90\%), the economic return from the sales of $60 \%$ of the diversified products from CAS, have the potential to stabilize the farmers' incomes. The higher cash incomes enhance the farmers' buying power with respect to additional food, especially when the main crop cocoa fails.

Almost all (98\%) of respondents indicated that the diverse products from CAS are a direct source of mineral nutrients for improving their household nutritional security especially for women and children. These food products aid them in alleviating deficiencies of iodine, protein, vitamin $A$ and iron as well as assisting the children of smallholder cocoa farmers escape from the likelihood of contracting Kwashiorkor, anaemia and xerophthalmia. Nutritional benefits from NTFPs in CAS help reduce the nearly 2 billion people suffering from micronutrient deficiencies (Barrett, 2014). 


\section{Agrochemical usage under CAS}

Little or no chemical inputs are used as shade levels increases. Table 3 clearly shows an inverse relation between the quantity of fertilizer used and number of shade trees. These results are in accordance with assertions by Schroth et al., (2000) indicating that in the case of cocoa plantations, agroforestry systems could modify pests and disease incidence compared with mono specific plantations. Padi and Owusu (1998) also recommended 10 to15 trees per hectare to be maintained within the cocoa plantation to avoid some of the dangers of disease and pest incidence associated with the heavy shade system.

\begin{tabular}{ccccc}
\hline Agrochemicals/ha & No shade & Low shade & Medium shade & Heavy shade \\
\hline Weedicide $(\mathrm{l})$ & 2.28 & 1.95 & 1.85 & 0.72 \\
\hline Fertilizer $(\mathrm{kg})$ & 215.25 & 160 & 144 & 126.5 \\
\hline Fungicide $(\mathrm{g})$ & 213 & 176.75 & 171.75 & 90.75 \\
\hline Insecticide $(\mathrm{l})$ & 2.35 & 2.36 & 2.22 & 2.10 \\
\hline
\end{tabular}

Table 3.

Quantity of agrochemical use under different $C A S$

Source: field survey, 2012.

\section{Cocoa yields under CAS}

The yield curve model, adopted from Ryan et al., (2007), was used to estimate the yield trends under the various CAS. The $\mathrm{R}^{2}$ values obtained under the no shade, low shade, medium shade and heavy shade were $77,61,53,56$ per cent respectively. The equations for estimating the yield of cocoa during the 40 years' production cycle are as follows:

$\begin{array}{ll}Y=\exp (-2.6720-0.3198 A+5.2176 \ln (A)) & \text { No shade 2 } \\ Y=\exp (1.8722-0.1022 A+2.2411 \ln (\boldsymbol{A})) & \text { Low shade 3 } \\ Y=\exp (3.8458-0.0784 A+1.4428 \ln (\boldsymbol{A})) & \text { Medium shade 4 } \\ Y=\exp (-0.0002-0.2600 A+3.7676 \ln (\boldsymbol{A})) & \text { Heavy shade 5 }\end{array}$

Where $\boldsymbol{Y}$ is cocoa yield per hectare and $\boldsymbol{A}$ is age of the cocoa farm in years. 
Figure 3.

Cocoa yield pattern in different $C A S$ in Ghana

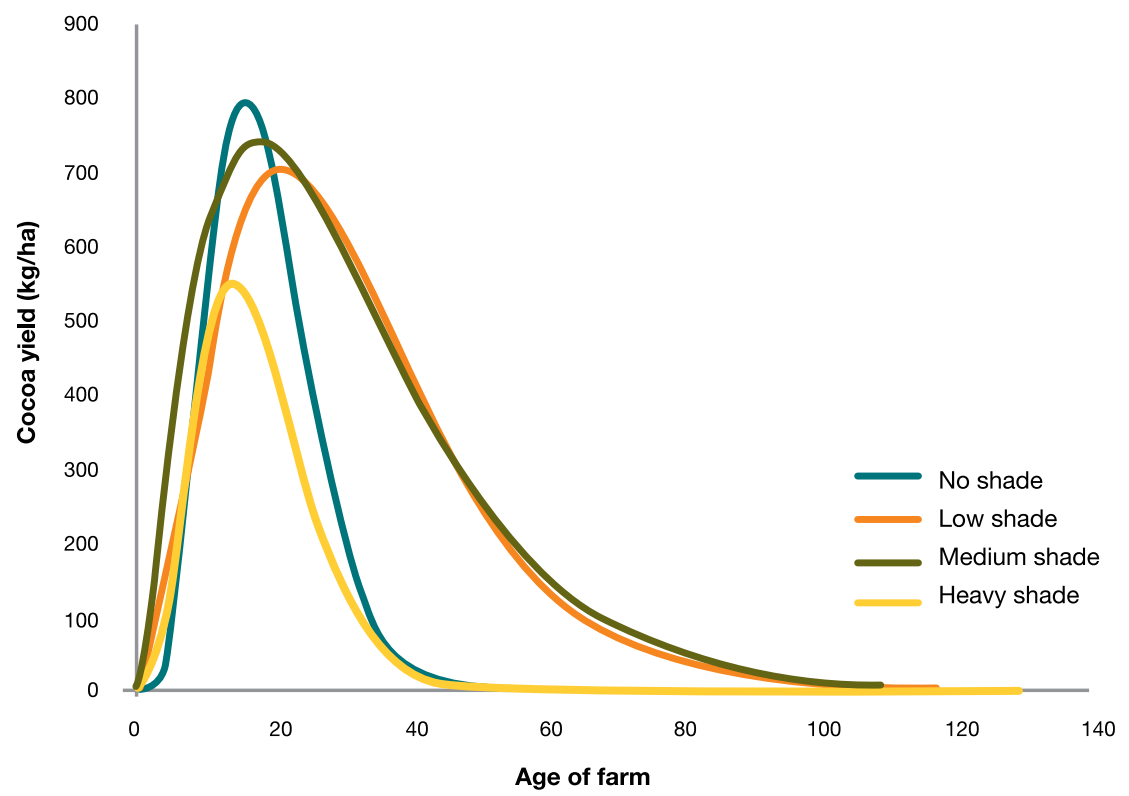

The yield curve under the full sun system shows a sharp rise in the yield, followed by a very sharp fall in the yield after age 16 . The medium shade has a gradual yield till it peaks at age 19 followed by a gradual fall in yield till age 80. Table 4 shows that, the average yield per hectare of the full sun, low shade, medium shade and heavy shade regimes were 794 $\mathrm{kg} / \mathrm{ha}, 696 \mathrm{~kg} / \mathrm{ha}, 735 \mathrm{~kg} / \mathrm{ha}$ and $546 \mathrm{~kg} / \mathrm{ha}$ respectively.

Table 4. Cocoa yields under different $C A S$

\begin{tabular}{lcccc} 
Characteristics & No shade & Low shade & Medium shade & Heavy shade \\
\hline Average yield $(\mathrm{kg} / \mathrm{ha})$ & 516 & 588 & 559 & 380 \\
\hline Highest yield obtained (kg/ha) & 794 & 696 & 735 & 546 \\
\hline Year of highest yield (years) & 16 & 22 & 19 & 15 \\
\hline
\end{tabular}

Source: field survey, 2012. 


\section{Empirical results}

Cocoa farmers' decision to adopt or not to adopt CAS is assumed to be the outcome of a complex set of factors related to the farmers' objectives and constraints. Prior to the econometric estimation, different econometric model assumptions were tested to check for possible model specification errors. In cross-sectional data set, multicollinearity is very common. Multicollinearity was addressed using pair-wise correlation matrix. This led to dropping some of the variables that showed the multicollinearity problem.

The model was statistically significant at $1 \%$ significance level. Tests showed that the model was free from multicollinearity. The Hosmer-Lemeshow test was also done to determine the goodness of fit of the model. The statistical significance confirms that the model fitted well and $78.50 \%$ of the values were correctly classified, the rest were misclassified.

\begin{tabular}{lccccc} 
Variable name & Estimate & SE & Wald & p (Sig.) & Odds ratio \\
SEX & .227 & .528 & .185 & 0.667 & 1.255 \\
\hline HHSIZE & .068 & .089 & .582 & 0.445 & 1.070 \\
\hline FAMORG & .925 & .489 & 3.585 & $0.058^{\star}$ & 2.522 \\
\hline EXTSERV & .733 & .405 & 3.270 & $0.071^{\star}$ & 2.081 \\
\hline COCVAR & -3.269 & .790 & 17.111 & $.000^{\star \star \star}$ & .038 \\
\hline AGE & -.009 & .017 & .278 & 0.598 & .991 \\
\hline EDUC & -.125 & .108 & 1.348 & 0.246 & .883 \\
\hline FMSIZE & -.225 & .152 & 2.182 & 0.140 & .798 \\
\hline CASTRAIN & 1.945 & .661 & 8.641 & $0.003^{\star \star \star}$ & 6.990 \\
\hline Constant & 3.107 & 1.187 & 6.853 & $0.009^{\star \star \star}$ & 22.357 \\
\hline Goodness-of-fit tests & & & & \\
Model chi-square $=67.249 \mathrm{p}<0.000$ & & & & \\
-2 log likelihood $=157.6859$ & & & & & \\
Pseudo R2 (Nagelkerke) $=0.423$ & & & & & \\
\hline
\end{tabular}

Table 5.

Logistic regression estimates for determinants of adoption of cocoa agroforestry

Notes: ${ }^{* *}$ significant at $1 \%$; ${ }^{* *}$ significant at the $5 \%$ level; * significant at the $10 \%$ level.

These case study results indicate that household size, age of respondents, level of formal education and farm size are not statistically significant in the adoption of CAS. The positive coefficient on the gender variable indicates that males are more likely to adopt CAS than females. The farm size holding by respondents seems unimportant in decision making. Neither was level of education an important factor in explaining the decision making on CAS. 
Some of the important factors that do impact on decision making were: access to extension services by farmers; membership of farmers' organizations; and obtaining information on CAS. The cocoa variety used by the farmer is statistically significant in affecting adoption of CAS. The negative sign of the coefficient of cocoa variety shown in Table 4 indicates that the respondents were more in favour of growing the hybrid cocoa variety on farms, which is associated with shade reduction. It comes as no surprise that most (80\%) of the new cocoa planting in the western region has been established without shade or less than $10 \%$ canopy cover (Katoomba Group, 2009). According to Kolavalli and Vigenri, (2011) trees have been cut down en masse in recent years to accommodate the open field variety, which grows in full sun conditions.

Some researchers like Padi and Owusu, (1998) and Osei-Bonsu and Anim-Kwapong (1998) advocate for mild shade to achieve high yields and precocity. The researchers further assert that, in Ghana the recommendation is to reduce overhead shade down to a maximum of 10 large and 15 medium sized trees per hectare or four trees per acre. Tree canopies can create a more adequate microclimate for crops and more resilient ecosystems for better food production.

Aside from the sustainable yield and direct and indirect benefits, CAS have the potential of restoring degraded forest landscapes. Adopting for example, medium shade CAS require retaining 10-15 trees per hectare. This could result in the planting of 500,000 to 750,000 trees annually with the annual increase of cocoa farm size by 50,000 hectare. If the annual rate of cocoa extensification of 50,000 hectares continues, by 2030 Ghana's cocoa land size would have reached 2,900,000 hectares. Policy intervention ensuring that all cocoa farmers inter plant 10-15 trees per hectare on their cocoa farms could restore the 2,900,000 hectares of this degraded land with about $29,000,000-43,500,000$ trees by 2030. 


\section{Conclusion and recommendations}

This paper presents an overview on the food production and landscape restoration potential of CAS with special reference to Ghana, where increasing human population pressure and levels of land degradation are aggravating scarcity of arable land. Forest and land degradation, as well as declining crop yields, signify, or are indicators of, poverty and food insecurity, especially for smallholder households in Ghana.

Cocoa agroforestry system emerges as a promising land use option to overcome the problem of land degradation and food insecurity. The direct and indirect benefits derived from such interventions have the potential to ensure food sufficiency. The case study showed that there were no significant differences in gender, age, number of years of schooling, farm size and household size to the adoption of CAS. The study results indicate that males are more likely than females to adopt CAS. The econometric analysis indicated that planting hybrid cocoa varieties, extension services, membership of farmers' association and training are the key factors indicating the adoption of CAS among smallholders in Ghana.

The medium shade CAS is seen as a win-win solution that can support the restoration of deforested and degraded forest landscapes by focusing on intercropping cocoa plantations with 10 to 15 trees per hectare (or four trees per acre). The study recommends that smallholder cocoa farmers' attitudes towards CAS should be positively encouraged by connecting cocoa farmers and distributors of information and knowledge through the creation of networks such as mass media, magazines, databases, cooperatives and nonprofit information distributers. Also, policies to promote this practice need to ensure training programmes and relevant extension services to educate cocoa farmers on ecosystem services and food security benefits through the establishment of cocoa agroforestry. 


\section{References}

Afari-Sefa, V., Gockowski, J., Agyeman, F.N. and Dziwornu, A. (2010). 'Economic cost-benefit analysis of certified Sustainable cocoa production in Ghana'. Third Conference of African Association of Agricultural Economists, Africa and the Global Food and Financial Crisis, 19-23 September, 2010, Cape Town.

Baah F., Anchirinah, V. and Badu-Yeboah, A. (2009). 'Perceptions of extension agents on information exchange with cocoa farmers in the Eastern region of Ghana'. Scientific Research and Essay 4(7):694-699.

Bamfo, R.K. (2003). 'Policy and institutional reform for forestry: the Ghanaian experience'. Africa Forest Law Enforcement and Governance Conference, 13-16 October 2003, Yaoundé, Cameroon, 8pp.

Barrett C.B, and Bevis L.E.M. (2014). The micronutrient deficiencies challenge in African Food Systems. In: Sahn DE (ed) The fight against hunger and malnutrition: the role of food, agriculture, and targeted policies. Oxford University Press, Oxford. http://barrett.dyson.cornell.edu/files/papers/FetschriftPaperAugust2014.pdf. Accessed on 20/02/2015.

Boakye, K.A. and Baffoe, K.A. (2007). Trends in forest ownership, forest resources tenure and institutional arrangements: case study from Ghana. Forestry Policy and Institutions Working Paper. Rome: FAO.

De Lattre-Gasquet, M., Despéraux, D. and Barel, M. (1998) 'Prospective de la Filière du Cacao Plantation'. Recherche Développment 5(6):423-434.

Duguma, B., Gockowski, J. and Bakala, J., (1998). 'Smallholder cacao (Theobroma cacao Linn.) cultivation in Agroforestry systems of West and Central Africa: Challenges and opportunities'. ICRAF-Yaoundé, 25pp.

Duguma, B., Gockowski, J. and Bakala, J. (2001). 'Smallholder cacao (Theobroma cacao Linn) cultivation in agroforestry systems of West and Central Africa: Challenges and opportunities'. Agroforestry Systems 51:177-188.

FAO (2010). Global Forest Resources Assessment, 2010. Country report, Ghana. Rome, Italy: Food and Agricultural Organization.

Ghana Statistical Service (2012). Ghana Population and Housing Census. National Analytical Report. Accra, Ghana: Ghana Statistical Service.

Haggblade, H., Tembo, G. and Donovan, C. (2004). Household level financial incentives to adoption of conservation agricultural technologies in Africa. Michigan State University Food Security Research project working paper no. 9, Lusaka, Zambia.

ISSER (2013). The State of the Ghanaian Economy in 2012. Legon: Institute of Statistical Social and Economic Research, University of Ghana.

Katoomba Group (2009). XV Meeting on Integrated Solutions: Water, Biodiversity, and Terrestrial carbon in West Africa. Accra, Ghana, 6-7October 2009.

Kotto-Same, J.P.L., Woomer, M., Appolinaire, M. and Zapfack L. (1997). 'Carbon dynamics in slash-and-burn agriculture and land use alternatives in the humid forest zone of Cameroon'. Agriculture Ecosystems and Environment (65):245-256.

Kolavalli, S. and Vigneri, M. (2011). 'Cocoa in Ghana: Shaping the Success of an Economy'. In: Chuhan-Pole, P. and Angwafo, M. (eds) Yes, Africa Can: Success Stories from a Dynamic Continent. Washington, DC: World Bank, 201-217. 
Kumar, B.M. (2006). 'Agroforestry: the new old paradigm for Asian food security'. Journal of Tropical Agriculture 44(1-2): $1-14$.

Maddala, G.S. (1983). 'Limited-dependent and qualitative variables in econometrics'. Volume 3 of Econometric Society Monographs in Quantitative Economics. Cambridge, UK: Cambridge University Press.

Mbow, C., Van Noordwijk, M., Luedeling, E., Neufeldt, H., Minang, P. A. and Kowero, G. (2014). 'Agroforestry solutions to address food security and climate change challenges in Africa. Current Opinion in Environmental Sustainability 6:61-67.

Mercer D.E and Miller R.P (1998). 'Socio-economic research in Agroforestry: progress, prospectus and priorities'. Agroforestry Systems 38:177-193.

MOFA-SRID (2014). Facts and Figures 2013. Ministry of Food and Agriculture: Statistics, Research and Information Directorate.

Ministry of Science and Environment (2002). National Biodiversity Strategy for Ghana. Ministry of Science and Environment.

Obiri, B.D., Bright, G.A., McDonald, M.A., Anglaaere, L.C.N. and J. Cobbina (2007). 'Financial Analysis of Shaded Cocoa in Ghana'. Agroforestry Systems 71:139-149.

Osei-Bonsu, K. and Anim-Kwapong, G.J. (1998). 'Preliminary evaluation of some forest trees for cocoa cultivation'. Journal of the Ghana Science Association 1(1):141-150.

Padi, B. and Owusu, G.K. (1998). Towards an Integrated Pest Management for Sustainable Cocoa Production in Ghana. Paper from workshop held in Panama, 30 March-2 April1998. Washington, DC: Smithsonian Institution.

Ruf, F. and Zadi, H. (1998). Cocoa: From deforestation to reforestation. Paper from workshop on Shade Grown Cocoa held in Panama, 30 March-2 April1998. Washington, DC: Smithsonian Institution.

Schroth, G., Krauss, U., Gasparotto, L., Duarte Aguilar, J.A. and Vohland, K. (2000). 'Pests and diseases in agroforestry systems of the humid tropics'. Agroforestry Systems 50:199-241.

Seeberg-Elverfeldt, C., Schwarze, S. and Zeller, M. (2009). 'Payments for Environmental Services - Incentives through Carbon Sequestration Compensation for Cocoa-based Agroforestry Systems in Central Sulawesi, Indonesia'. International Journal of the Commons vol. 3.

Thorlakson, T. and Neufeldt, H. (2012). 'Reducing subsistence farmers' vulnerability to climate change: evaluating the potential contributions of agroforestry in western Kenya'. Agriculture and Food Security 1(15):1-13.

Vlek, P.L.G., Le, Q.B. and Tamene, L. (2010). 'Assessment of land degradation, its possible causes and threat to food security in Sub-Saharan Africa'. In Raton, E. (ed.): Food Security and Soil Quality Advances in Soil Science. USA: Taylor \& Francis 57-86.

UNDP (2011). Greening the sustainable cocoa supply chain in Ghana.

Ryan, D., Bright, G.A. and Somarriba, E. (2009). 'Damage and yield change in cocoa crops due to harvesting of timber shade trees in Talamanca, Costa Rica'. Agroforestry Systems 77(2):92-106. 


\section{Economic contribution}

of communal land

restoration to food

security in Ethiopia: Can

institutionalization help?

Yitbarek Tibebe Weldesemaet

Watersheds Organizational and Livelihoods Affairs Support (local NGO) P.O. Box-34793, Addis Ababa, Ethiopia

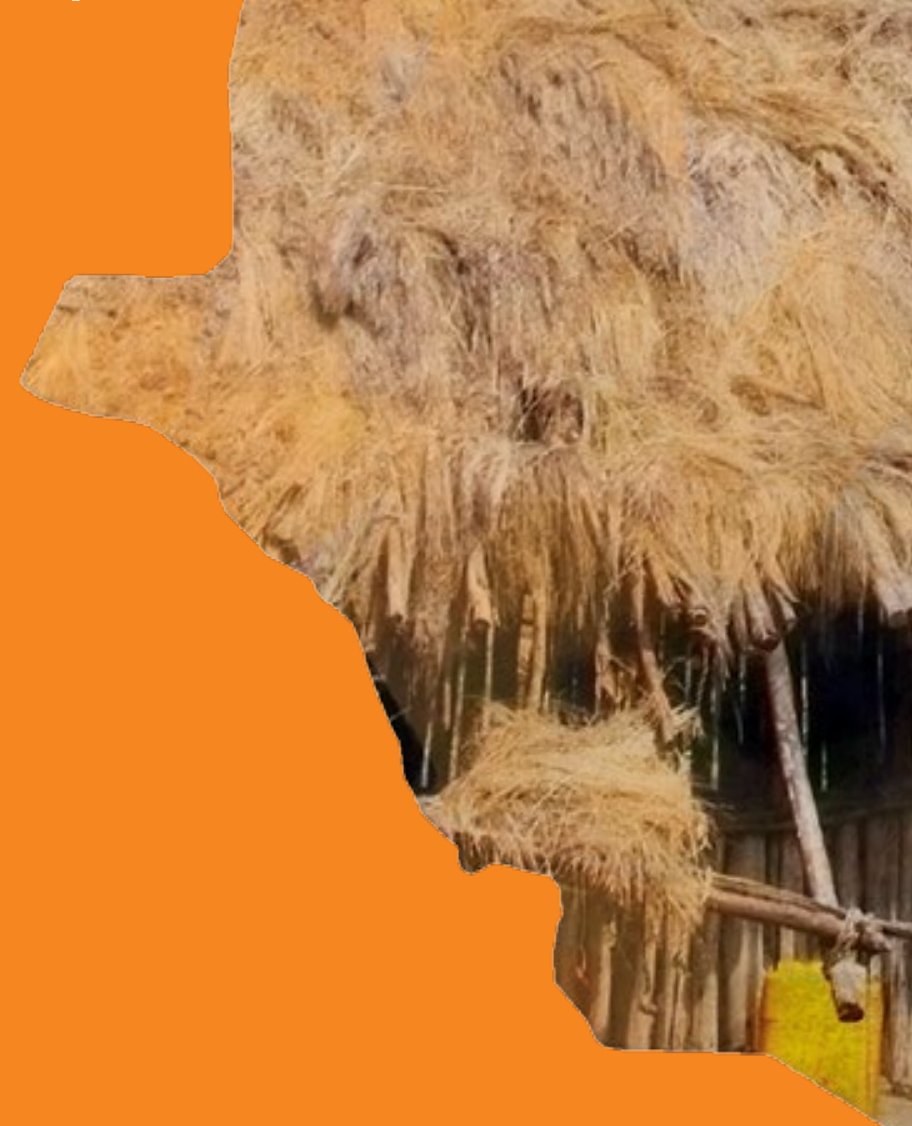




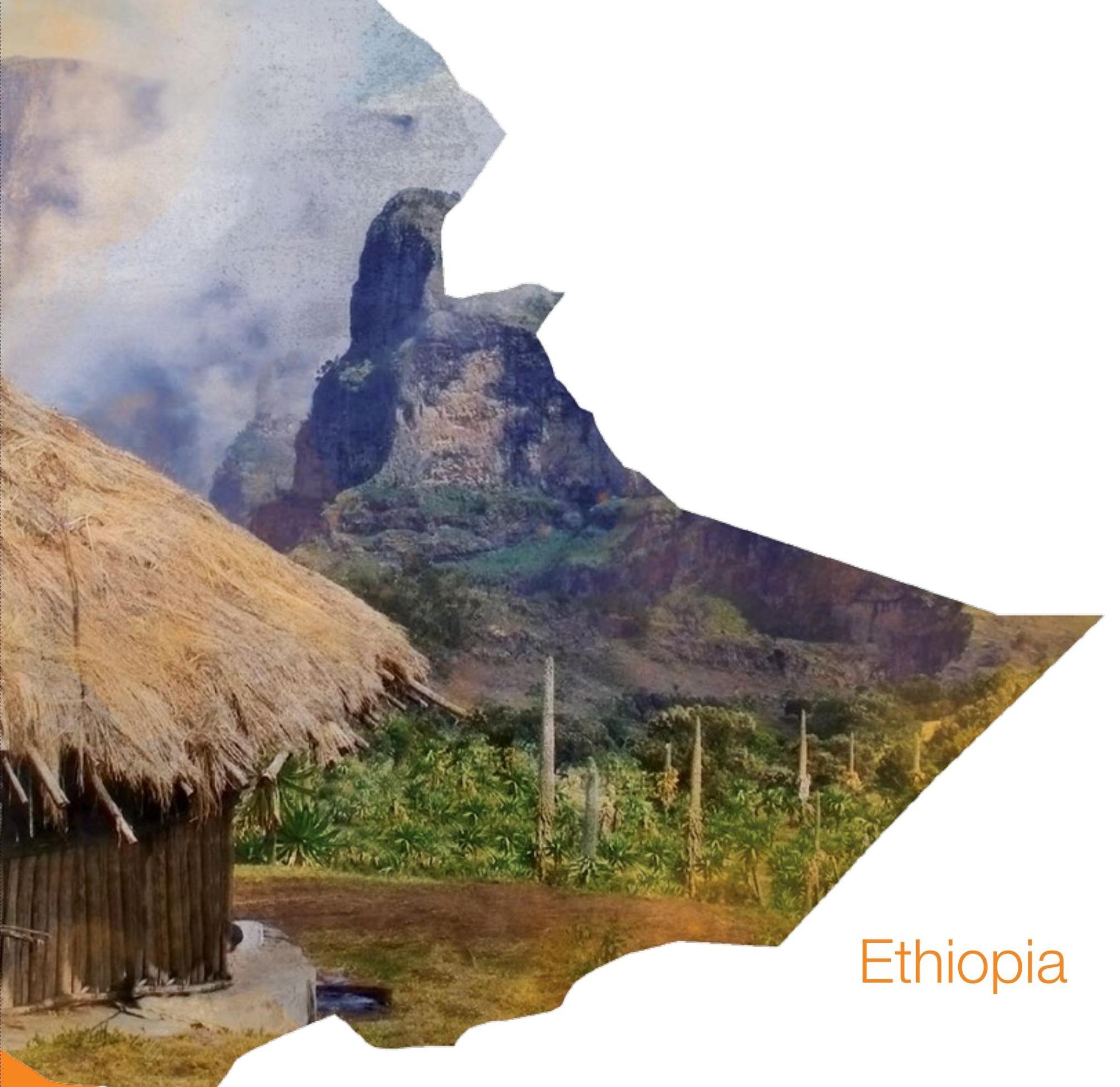





\section{Introduction}

Institutionalizing community-based natural resource management has been promoted since the 1980s and has been a topic of research and development (Agrawal, 2001; Blaikie, 2006; Abernethy, et al., 2014). The concept of decentralizing power and transferring the resource management responsibilities to local communities has been practised in most part of the world with several success and failure stories evidenced. Boonzaaier (2012) proposed a model of community institutional structure built on existing practices in South Africa, which proved the idea that, without direct involvement the community members tend to have little interest and act destructively. Wehkamp, et al., (2013) through examples from different country case studies also demonstrated that for sustainable resource management the institutional design makes the critical difference. Furthermore, several studies demonstrated that adjusting and revitalizing community institutions are essential for ensuring livelihoods and sustaining natural resources (Nelson \& Agrawal, 2008; Mbaiwa, 2009; Poteete, 2009). The adaptability of institutions to changing sociocultural norms and non-heterogeneous populations is also underscored as a major success criterion along with congruent rules, collective choice, conflict resolution mechanisms, legally recognized rights and economic viability.

Ecological restoration opportunities can contribute substantially to all aspects of livelihoods in rural communities (Blignaut, et al., 2010) and thereby strengthen food security (Blignaut, et al., 2013). Investing in restoration interventions and their proper planning management are vital to achieving food security (Cao, et al., 2009). Successful ecological restoration requires the proper institutional set up and ensuring that beneficiaries obtain benefits from the natural resources on which they depend for their livelihoods (Wiggins, et al., 2004; Sachs \& Reid, 2006; Yayneshet, 2011; Mekuria \& Aynekulu, 2013). 


\section{Background}

Ethiopia, located in the north-eastern highlands of tropical Africa, has a unique geography with enormously diversified edaphic, climatic and biological resources. The Ethiopian landmass covers a wide altitudinal variation, ranging from $110 \mathrm{~m}$ below sea level to $4,620 \mathrm{~m}$ above sea level. The country has a population of more than 80 million, of which around $85 \%$ is rural, obtaining livelihoods from agriculture, which suffers from low productivity. Land degradation and droughts are major contributors to the lack of productivity of land in Ethiopia (Holden, et al., 2003). Mainly associated with high population pressure, deforestation, overgrazing and unsustainable utilization of natural resources, Ethiopia's natural resource base has been deteriorating over time. The rate of deforestation in Ethiopia is estimated at 160,000 to 200,000 hectares per year, and the national soil loss is estimated to be up to 300 tonnes/ha/yr while the study region's rate is estimated at $56 \%$ the national rate (Birhanu, 2014). The degraded communal areas are characterized by irregularly spaced trees and shrubs and vast areas of bare land devoid of vegetation, with some gullies (Nedessa, et al., 2005; Mekuria \& Aynekulu, 2013). This is exacerbated by climate variability which is the major source of natural resource degradation (Henry, et al., 2007); combined with lack of awareness and initiatives to mitigate the impacts of climate change on land and vegetation (Muna, et al., 2009; Chirwa, 2014). In efforts to enhance the degraded land, the Ethiopian Government and its partner NGOs have committed millions of dollars annually to restore the degraded communal areas (Bekele-Tesemma, 2002; Dewees, et al., 2011). Despite the hefty capital investment, success, in terms of scaling up and continued sustainable management of restoration activities, has been limited (Desta, et al., 2005; Demeke, 2011). This is thought to be due to lack of institutionalization aligned with restoration implementation efforts (Liu, et al., 2008). 


\section{Restoration interventions}

This case study is built on the assessment conducted in 2008 of 25 pilot communal areas in northern Ethiopia that were restored by the Integrated Food Security Project of a government and bilateral NGO restoration programme. The project focused on social mobilization, institutionalization of beneficiaries and livelihood development as a strategy to restore, sustain outputs and make use of the assets derived from the restored land. The project ensured that the beneficiaries established the sustainable, self-reliant, empowered organizations for managing the implementation of restoration activities; including the legally formed community organizations and community project interest groups for each pilot communal area. These organizations were the project's key element in leading the restoration activity and identifying priority livelihood means and needs of the targeted groups. The interest groups under the beneficiaries' organization helped develop financial stability and money management capacity through funding under the project's community investment fund (CIF). During the final stage the project primarily focused on expanding livelihood opportunities from the restoration outputs by creating sustainable farm, off-farm and non-farm employment opportunities such as micro enterprises, livestock development and value addition to farm produce, trading, etc.

The Kanat communal area (Figure 1), which is 13.26 hectares, is one of the 25 pilot restoration areas, consisting 230 beneficiaries. It is in a region where population growth rate is $2.9 \%$, with an average family size of 5 and land holding of 1.4 hectares (ANRS, 2006; Girma, et al., 2006; BoARD, 2010; Ejigu, et al., 2009; ANRS-BoFED, 2010). These beneficiaries have set up an institution to initiate the restoration activities and to maintain sustainable management of the restoration outputs. Prior to the restoration project, the Kanat communal area had been used for free unsustainable grazing and was severely eroded to the extent of gully formation. In restoring this communal area the government and a bilateral NGO worked with the legal beneficiaries of the communal area. Together, they considered: the choice of species to be planted and the types of soil and water conservation measures to be adopted; the protection and sharing of restoration outputs and the likely benefits that would accrue to the beneficiaries; and, finally, getting legal recognition from the government justice department to protect the restored site and make its management sustainable. 
Figure 1.

Location of the Kanat communal rangeland area

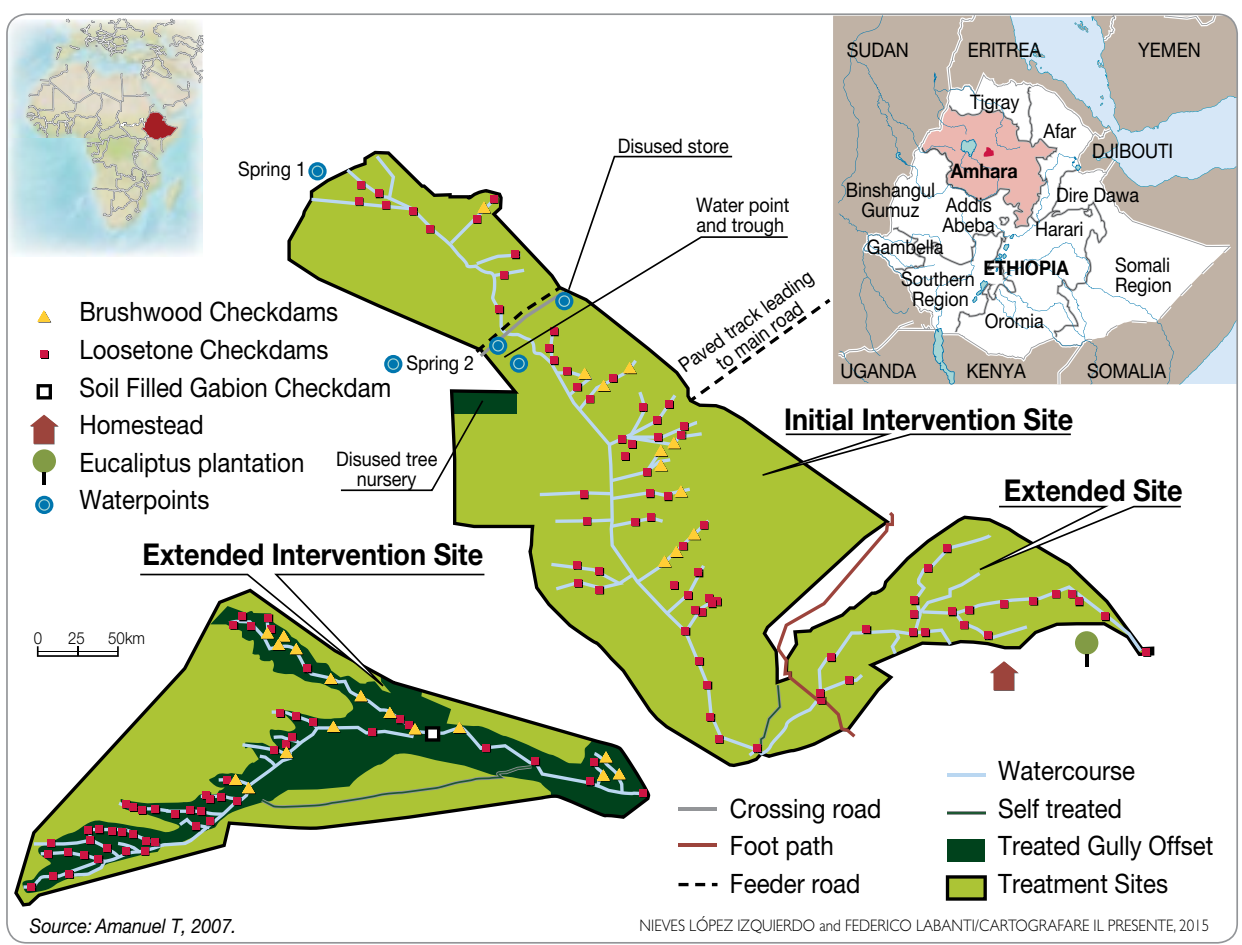

A variety of fast-growing indigenous and non-native trees taking up to 20 years to mature were planted to enrich the flora in the area and to provide much needed animal fodder (Tables 1 and 2). Plantings were designed with the multiple aims of providing soil and water conservation, fodder, construction and fuel material, and nutrient enrichment. Thus the tree species within these restored watersheds are multi-purpose, with fuelwood and construction being the most important uses. They include nyanga flat-top (Acacia abyssinica), silk-oak (Grevillea robusta), orange wattle (Acacia saligna), poplars (Populus ciliata), kosso (Hagenia abyssinica), blackwood (Acacia melanoxylon). These tree species are planted at a density of 273 trees/ha. Bare spaces were seeded with grass and legumes, such as weeping Pennisetum sp., harding grass (Phalaris aquatic), crown vetch (Coronilla varia). Across gullies, the restoration involved the use of temporary physical structures, including loose stones, 'organic' gabion boxes (made from bamboo and reed strips, woven and tied together and filled with stones) and wired gabion boxes. Gunny bags (reed boxes filled with stones and soil), arc wires (meshed wire boxes filled with stones), were used 
together with other check-dam structures. These were intended to function as an interim measure until more permanent structures (multi-purpose trees and grasses) became established.

- The beneficiaries agreed to set up an institution and effective legal bylaws for the use and management of the restoration outputs such as trees, shrubs and grass. Key activities in the legitimization process were drafting official documents:

- The association statute, which defines the association's territory, objectives, membership, organs, rights and duties.

- The natural resources bylaw which aims to regulate the sustainable use of common property resources and to enforce user compliance, as well as to implement collective schemes for soil and water conservation and natural resources conservation.

- The certificate that shows the association legally represents the communal land beneficiaries.

The body responsible for drafting the statutes and bylaws is the beneficiaries' elected committee members. The form sanctions (social or legal) should take is also decided by this committee. The draft must be presented to all beneficiary members and any changes agreed. The bylaw is then presented to the government authority for approval. After approval, the association is fully responsible for defining and executing the rules and regulations, including on the use of restoration outputs, which ensures that beneficiaries share the fodder each year and protect the trees from damage. When the trees are mature enough, as agreed by the beneficiaries and the agriculture office, the natural resource bylaw states that beneficiaries shall cut down $1 \%$ each year and conduct a replacement planting as needed. 


\section{Case study analysis}

The restoration projects have been predominantly viewed by majority stakeholders as an expense (cost), with few tangible financial and economic benefits to the rural community (Blignaut, et al., 2014). Often this is associated with erroneous accounting practices and a tendency of conventional cost-benefit analyses to exclude the impact of human activities on ecosystem goods and services (Rees, et al., 2007; Farley, 2008). Even in academic literature, the economic benefits to beneficiaries of restoration have only recently begun evolving in science and practice (Aronson, et al., 2010; Wang, et al., 2011; De Groot, et al., 2013). More specifically, very few restoration researchers in Ethiopia have barely touched the economic advantages of communal land restoration to rural livelihoods (Babulo, et al., 2009; Yitbarek, et al., 2010; Mekuria, et al., 2011; Chisholm \& Woldehanna, 2012). Thus, restoration efforts have not been economically justified in terms of their value to communal land and/or financial returns to beneficiary rural livelihoods. Therefore, the goal of this case study is to quantify the economic returns of communal land restoration by evaluating the restoration outputs at present and estimating the future (long-term) benefits expected from large-scale restoration. Moreover, this study will attempt, empirically, to suggest that the restoration efforts are economically viable and sustainable when complemented with institutionalization of communities. Specifically, this case study strives to answer:

- Have the restoration interventions in the pilot area met the expectation of improving rural livelihoods?

- How did the institutionalization of the communal area ensure the sustainability of natural resource and beneficiaries' livelihoods development?

The restoration cost was obtained from the restoration project implementers and compared with the physical assessment of the restoration outputs: tree volume, fodder biomass, soil carbon and carbon sequestered.

The volume of standing trees $(V)$ is composed of the merchantable wood volume plus the crown volume. Merchantable wood volume is measured and estimated using a standard formula as a function of three basic parameters: diameter at breast height (DBH), height ( $h$ ) and form factor (f) (Magnussen \& Reed, 2004; Akindele \& LeMay, 2006; Brandeis, et al., 2006). 


$$
\mathrm{V}_{\mathrm{m}}=\mathrm{B}_{\mathrm{bh}} \mathrm{h}_{\mathrm{m}} \mathbf{f} \quad \mathbf{B}=\boldsymbol{\pi} / \mathbf{4} \times \mathrm{XD}^{2} \quad \mathbf{f}=\mathbf{0 . 4 2 5}
$$

Where: $\mathbf{V}_{\mathbf{m}}$-merchantable wood volume of standing trees $\left(\mathrm{m}^{3}\right) ; \mathbf{B}_{\mathbf{b h}}$-basal area at breast height $\left(\mathrm{m}^{2}\right) \mathbf{D}$-diameter at breast height $(\mathrm{m}) ; \mathbf{h}_{\mathbf{m}}$-tree merchantable height $(\mathrm{m}) ; \mathbf{f}$-form factor.

The standing crown volume is obtained by measuring three parameters: crown spread; crown thickness; and crown shape ratio (Blozan, 2008; Rautiainen, et al., 2008; Frank, 2010). Crown shape ratio is determined by visual comparison with a chart to derive a crown form (CF).

\section{Crown volume $=(C F) \times($ crown thickness $) \times(\text { average maximum crown spread })^{2}$ $\mathrm{CF}=\left[(\pi)(\text { crown shape ratio })^{2}\right] / 4$}

In estimating the biomass of trees found in the above ground biomass (AGB) and below ground biomass (BGB) of trees, allometric models are used. For AGB the model by Chave, et al., (2005) was chosen, because it incorporates data from different tropical countries relying on model selection based on penalized likelihood (Preminger \& Wettstein, 2005).

$$
(A G B)=\exp \left(-2.977+\ln \left(\rho D^{2} H\right)\right.
$$

Where: AGB = above ground biomass (tonne); $\boldsymbol{\rho}=$ density of wood $\left(\mathrm{kg} / \mathrm{m}^{3}\right) ; \mathbf{D}$ diameter at breast height $(\mathrm{m}) ; \mathbf{H}=$ height $(\mathrm{m})$.

The widely used efficient and effective method to estimating BGB is to apply a regression model from knowledge of AGB as in Pearson, et al., (2005).

$$
\text { BGB }=\exp (-1.0587+0.8836 \times \ln \text { AGB })
$$

Where: $\mathbf{B G B}=$ below ground biomass $(\mathrm{kg})$.

In estimating grass biomass the clip-and-weigh method is used here because it yields the most accurate value (Butler, 2007; Oliveras, et al., 2014). This was done by harvesting each grass species from a 50×50 cm sample plot and oven drying, weighing and extrapolating to the whole area. 
The carbon sequestered in the biomass of trees and grasses is obtained by considering the carbon content of dry biomass to be 47\% (Elias \& Potvin, 2003; Malhi, et al., 2004; Pearson, et al., 2005).

\section{C = biomass x 0.47}

Where: $\mathbf{C}=$ carbon sequestered; biomass $=$ AGB, BGB or grass biomass .

In estimating soil carbon, systematic soil sampling is used with a horizontal sampling of a $5 \times 5$ metre grid scheme. For analysing the organic carbon $(\mathrm{OC})$ in the soils the Kjeldahal method is used (Walkley and Black, 1934). The percentage result is converted to $C$ mass $(\mathrm{kg})$, and scaled up to the soil of the whole study area (Yitbarek, et al., 2012).

In estimating the monetary value of the restoration outputs, such as tree wood, crown and fodder, the local market price was assessed and the official market assessment documents were examined, checking the price of tree or crown volume and grass fodder mass over the years and seasons of each species. Considering the price difference for the varying species, mean prices were used to obtain one single value for all tree species and all grass species.

In valuing carbon sequestered in the soils and biomass, the international voluntary markets are assessed (Walkera, et al., 2008). The voluntary market prices for afforestation/ or reforestation plantation and conservation from the over-the-counter (OTC) market ranged from US\$ 0.65 to over US\$ 50 per tonne $\mathrm{CO}_{2}$ e while the mean price for Africa is US\$ 10.38 per tonne $\mathrm{CO}_{2} \mathrm{e}$ (Hamilton, et al., 2009; 2010) where $\mathrm{CO}_{2} \mathrm{e}=$ carbon $\times 3.667$ (Walkera et al., 2008).

In estimating the future maximum output and maturation time from the study area, the mean results are obtained from similar agro-ecological areas and published studies (Pandey, 1983; Vanclay, 1994; Pretzsch, 2010; Burkhart a\& Tome, 2012). Although the tree volume and carbon change significantly in the future, the yield of grass (fodder or carbon) and soil carbon is not expected to show significant variation. In fact several researchers have determined that measuring soil carbon change is laborious and expensive when compared with the estimated small change (Ellert, et al., 2002; Martens, et al., 2003; Teklay \& Chang, 2008; Lichter, 2008). Due to market price volatility it is hard to estimate future output prices, hence, current market prices are used in estimating future values. The future value of the restoration outputs is discounted in order to compare it with the 2008 outputs value. In discounting, the National Bank of Ethiopia's interest rate index was used (3\%) which is the smallest realistic index. 


$$
\mathbf{P}=\frac{a}{(1+i)^{n}}
$$

Where $\mathbf{P}=$ present value of money; $\boldsymbol{a}=$ principal found; $\boldsymbol{i}=$ interest rate index $3 \% ; \boldsymbol{n}=$ number of years to obtain principal.

The benefits from the large-scale restoration intervention are estimated by taking the maximum output estimates and the current market prices of the study area. 


\section{Results}

In this study a complete inventory was conducted to make sure that the results obtained were precise. The data for this study were obtained using a metre tape to measure all the parameters in Table 1 which are required for tree volume and biomass estimation.

Table 1.

Tree parameters measured mean value in 2008 and mean maximum growth by 2025

\begin{tabular}{|c|c|c|c|c|c|c|c|c|c|}
\hline \multirow{2}{*}{ Species } & \multirow{2}{*}{$\begin{array}{l}\text { Species } \\
\text { frequency }\end{array}$} & \multicolumn{2}{|c|}{ DBH $\left(\mathrm{cm}^{2}\right)$} & \multicolumn{2}{|c|}{$\begin{array}{c}\text { Merchantable } \\
\text { height }(\mathrm{m})\end{array}$} & \multicolumn{2}{|c|}{$\begin{array}{c}\text { Crown height } \\
(\mathrm{m})\end{array}$} & \multicolumn{2}{|c|}{$\begin{array}{c}\text { Crown } \\
\text { diameter }(m) \\
\end{array}$} \\
\hline & & 2008 & 2025 & 2008 & 2025 & 2008 & 2025 & 2008 & 2025 \\
\hline $\begin{array}{l}\text { Acacia } \\
\text { abyssinica }\end{array}$ & 287 & 7.3 & 47 & 1.2 & 8 & 2.0 & 14 & 3.0 & 10 \\
\hline $\begin{array}{l}\text { Acacia } \\
\text { angustissima }\end{array}$ & 802 & 5.4 & 25 & 4.1 & 4 & 2.6 & 3 & 2.4 & 4 \\
\hline $\begin{array}{l}\text { Acacia } \\
\text { melanoxylon }\end{array}$ & 102 & 5.0 & 35 & 3.2 & 11 & 1.6 & 14 & 2.2 & 6 \\
\hline Acacia saligna & 179 & 6.7 & 40 & 2.3 & 6 & 3.3 & 7 & 3.0 & 6 \\
\hline $\begin{array}{l}\text { Chamaecytisus } \\
\text { palmensis }\end{array}$ & 211 & 5.9 & 20 & 1.0 & 2 & 2.0 & 6 & 2.1 & 5 \\
\hline $\begin{array}{l}\text { Gravillia } \\
\text { robusta }\end{array}$ & 260 & 4.1 & 46 & 3.5 & 14 & 1.7 & 18 & 2.9 & 5 \\
\hline $\begin{array}{l}\text { Hagenia } \\
\text { abyssinica }\end{array}$ & 246 & 5.3 & 39 & 2.2 & 8 & 2.2 & 12 & 1.9 & 7 \\
\hline Populus ciliata & 896 & 6.6 & 45 & 6.7 & 10 & 2.8 & 15 & 2.5 & 4 \\
\hline $\begin{array}{l}\text { Salix } \\
\text { babylonica }\end{array}$ & 263 & 4.1 & 60 & 1.7 & 4 & 1.6 & 16 & 2.4 & 13 \\
\hline $\begin{array}{l}\text { Sesbania } \\
\text { sesban }\end{array}$ & 375 & 6.4 & 12 & 1.6 & 3 & 1.4 & 5 & 2.2 & 8 \\
\hline
\end{tabular}

The estimation of the biomass of grass species (non-tree vegetation) was done by harvesting samples of grass from $50 \times 50 \mathrm{~cm}$ plots approximately $1 \mathrm{~cm}$ above the ground. The samples were then separately air-dried for days. Subsequently, the mass of each sample was weighed consecutively for weeks, until almost similar measurements were recorded between consecutive weight measurements providing the dry grass biomass depicted in Table 2. 


\begin{tabular}{|c|c|c|c|}
\hline \multirow{2}{*}{ Species } & \multicolumn{2}{|c|}{ Cover } & \multirow{2}{*}{ Dry biomass $\left(\mathrm{kg} / \mathrm{m}^{2}\right)$} \\
\hline & $m^{2}$ & $\%$ & \\
\hline Arundo donax & 5,450 & 5 & 6.88 \\
\hline Coronilla varia & 15,343 & 13 & 1.4 \\
\hline Pennisetum clandestinum & 32,800 & 28 & 3.12 \\
\hline Pennisetum purpureum & 8,765 & 7 & 7.32 \\
\hline Pennisetum sp. & 3,819 & 3 & 15.2 \\
\hline Phalaris aquatica & 44,300 & 38 & 3.88 \\
\hline Sambucus nigra & 6,674 & 6 & 7.6 \\
\hline
\end{tabular}

Table 2.

Grass species area and dry biomass

In determining the price of these tree and grass species local market was checked for tree wood volume from construction wood price; crown from wood fuel market and grass from fodder market (Table 3). Carbon price depicted in Table 3 is regarded as hypothetical as there is at present no binding national market place for carbon in Ethiopia, and hence actual monetary transfers will have to take place from international markets.

\begin{tabular}{lcc}
\hline Description of outputs & Unit & Price in 2008 \\
\hline Merchantable wood volume & US\$ $\mathrm{m}^{-3}$ & 245 \\
\hline Crown volume & US $\$ \mathrm{~m}^{-3}$ & 20 \\
\hline Fodder mass & US\$ tonne-1 & 36 \\
\hline $\mathrm{CO}_{2}$ equivalents & US\$ tonne ${ }^{-1}$ & 10.4 \\
\hline
\end{tabular}

Table 3 ,

Market price of restoration outputs in 2008

Kanat communal land has been restored at a cost of US\$7,594 ha- ${ }^{-1}$ while the mean local expenditure to restore a hectare of communal land in the study area is US $\$ 10,100$ $\mathrm{ha}^{-1}$.The mean expenditure value is obtained from the restoration of other communal areas in the study region. The restoration expense line includes every expense from commencing the communal land surveying for restoration potential to the end of the last maintenance of damaged physical structures or vegetation cover. The cost incurred by the restoration implementers, includes wages for experts and labourers throughout the whole project period; the materials and equipment rented and/or purchased to facilitate the overall restoration.

The restoration outputs (wood volume and crown volume) provided a total value of US\$ 20,355 ha $^{-1}$ by 2008 and could yield a maximum value of US $\$ 464,627$ ha $^{-1}$ when the trees mature by 2025 (Table 4). The value estimated to be obtained in 2008 is a hypothetical 
value that the beneficiaries could earn if they had to cut the trees in 2008 . Similarly the 2025 value assumes the per hectare value of all trees in the area; though realistically beneficiaries agreed to only cut $1 \%$ of the trees every year after 2025 .

Table 4.

Tree volume yield and value in the year 2008 and 2025

\begin{tabular}{lccc}
\hline Description of estimates & Unit & $\mathbf{2 0 0 8}$ & $\mathbf{2 0 2 5}$ \\
\hline Merchantable wood volume & $\mathrm{m}^{3} \mathrm{ha}^{-1}$ & 1.2 & 109 \\
\hline Crown volume & $\mathrm{m}^{3} \mathrm{ha}^{-1}$ & 1,003 & 37,068 \\
\hline Merchantable wood value & US\$ ha-1 & 296 & 16,097 \\
\hline Crown value & US\$ ha-1 & 20,059 & 448,530 \\
\hline Standing tree value & US\$ ha-1 & 20,355 & 464,627 \\
\hline Total area tree value & US\$ & 269,900 & $6,160,955$ \\
\hline
\end{tabular}

Carbon sequestered by trees, grasses and soil has increased from 382 tonnes ha-1 in 2008 to 502 tonnes ha-1 by 2025. The value of this sequestered carbon however decreased from US\$14,551 $\mathrm{ha}^{-1}$ to US\$11,560 $\mathrm{ha}^{-1}$ by discounting the 2025 value in order to compare it with the 2008 value (Table 5).

Table 5.

Biomass yield and sequestered carbon value in the year 2008 and 2025

\begin{tabular}{|c|c|c|c|}
\hline Description of estimates & Unit & 2008 & 2025 \\
\hline Tree biomass & Tonne ha- $\mathrm{yr}^{-1}$ & 1.9 & 257 \\
\hline Grass biomass & Tonne ha ${ }^{-1} \mathrm{yr}^{-1}$ & 38.2 & 38 \\
\hline Tree carbon & Tonne ha ${ }^{-1} \mathrm{yr}^{-1}$ & 0.9 & 121 \\
\hline Grass carbon & Tonne ha ${ }^{-1} \mathrm{yr}^{-1}$ & 19 & 19 \\
\hline Soil carbon & Tonne ha- $\mathrm{yr}^{-1}$ & 362 & 362 \\
\hline Total carbon sequestered & Tonne ha ${ }^{-1} \mathrm{yr}^{-1}$ & 382 & 502 \\
\hline Marketable $\mathrm{CO}_{2}$ equivalents & Tonne ha- $\mathrm{yr}^{-1}$ & 1,402 & 1,841 \\
\hline Value of carbon sequestered & US\$ ha ${ }^{-1} \mathrm{yr}^{-1}$ & 14,551 & 11,560 \\
\hline Total area sequestered carbon value & US\$ yr-1 & 192,943 & 153,284 \\
\hline
\end{tabular}


The annual amount of fodder harvested from the study area; is 38 tones $\mathrm{ha}^{-1} \mathrm{yr}^{-1}$. This means beneficiaries harvested a fodder valued US $\$ 2,748 \mathrm{ha}^{-1} \mathrm{yr}^{-1}$ in 2008 while this will be US\$ 1,521 ha-1 $\mathrm{yr}^{-1}$ in 2025 (Table 6). Though the fodder mass is comparable its monetary value decreases from 2008 to 2025 because of discounting caused by inflation rate.

\begin{tabular}{lccc}
\hline Description of estimates & Unit & $\mathbf{2 0 0 8}$ & 2025 \\
\hline Fodder mass & Tonnes ha $^{-1} \mathrm{yr}^{-1}$ & 38 & 38 \\
\hline Total area fodder mass & Tonnes yr $\mathrm{r}^{-1}$ & 506 & 506 \\
\hline Fodder value & US\$ ha $\mathrm{yr}^{-1}$ & 2,748 & 1,521 \\
\hline Total area fodder value & US $\$ \mathrm{yr}^{-1}$ & 36,432 & 20,172 \\
\hline
\end{tabular}

By 2008 the total value added by the restoration outputs to Kanat communal area amounted to US\$499,275 and this could increase to US $\$ 6,336,281$ by 2025 . The actual restoration output shared by beneficiaries till 2008 is grass fodder, which has a value of US\$ $158 \mathrm{yr}^{-1}$ household $^{-1}$. According to the beneficiaries' legal bylaw, after the year 2025 (tree maturation time) the beneficiaries are also entitled to harvest and share $1 \%$ of the trees every year. This means after 2025 beneficiaries will harvest and share 1\% of the trees US\$ $61,610 \mathrm{yr}^{-1}$ plus the annual fodder US\$20,172 $\mathrm{yr}^{-1}$. Moreover if they manage to aggregate their restoration area with others they can also share benefit from carbon sequestration US\$ 153,284 $\mathrm{yr}^{-1}$. In total, each beneficiary household would earn a maximum annual income of US\$1,022 $\mathrm{yr}^{-1}$, which is over six times the amount they earned from sharing only fodder in 2008.

The Kanat beneficiary households have an additional unrestored 274 hectares of communal land area that is severely degraded and if they were to restore this large-scale communal area, they could obtain a maximum value after the 20th year by when all trees are expected to mature. In 20 years, the number of beneficiaries would also increase from 230 to 364 households based on the $2.9 \%$ population growth rate. If we assume that the new households share half of their private land (1.4 hectares) from the unrestored communal area, they would take 94 hectares off, leaving 180 hectares for restoration. The restoration of the 180 hectares will cost about US\$1,818,000 (180 ha x US\$10,100 ha-1 mean local restoration cost). This restoration expense can be paid back from the seasonally maturing fodder harvested each year. The fodder from this large-scale restoration is valued US\$ 304,254 $\mathrm{yr}^{-1}$ which will pay back the large-scale restoration expense in just six years. This means beneficiaries can harvest and share US\$ $836 \mathrm{yr}^{-1}$ of fodder after the 6th year
Table 6.

Grass fodder mass and value in 2008 
until the trees mature. After the trees mature beneficiaries will, in addition to the fodder, harvest and share $1 \%$ of trees (US\$ 850,399 $\mathrm{yr}^{-1}$ ) and, if they are able to aggregate with other restoration areas, a carbon credit of US\$1,611,277 $\mathrm{yr}^{-1}$ (Table 7). In total beneficiaries will share restoration outputs valued around US\$2,765,930 (Table 7). From this net return, each beneficiary household can expect to share an output valued US\$7,600 $\mathrm{yr}^{-1}$ after the trees mature.

Table 7. Maximum yield and value from 200 hectares

\begin{tabular}{lccc}
\hline Description of estimates & Unit & Yield amount & Value in US\$ \\
\hline Fodder mass & Tonnes $\mathrm{yr}^{-1}$ & 7,632 & 304,254 \\
\hline Sequestered carbon $/ \mathrm{CO}_{2}$ equivalents & Tonnes $\mathrm{yr}^{-1}$ & 280,360 & $1,611,277$ \\
\hline $1 \%$ of merchantable wood volume & $\mathrm{m}^{3} \mathrm{yr}^{-1}$ & 217 & 29,462 \\
\hline $1 \%$ of tree crown volume & $\mathrm{m}^{3} \mathrm{yr}^{-1}$ & 74,135 & 820,937 \\
\hline Total area value & US $\$ \mathrm{yr}^{-1}$ & & $2,765,930$ \\
\hline
\end{tabular}




\section{Discussion}

Valuing restoration ecosystems is an important tool when considering the costs and benefits of different options for achieving food security. Many provisioning services can come from restoration areas such as food, fodder, fibre and timber (TEEB, 2010). Restored areas also help increase infiltration and reduce runoff (regulatory services) and can be used to connect forest habitats; bringing insects for pollination and soil organisms closer to fields; soil conservation, improved crop productivity, hence food security; cycle nutrients and carbon (supporting services); and also diversify production by providing fuel wood and timber in addition to fodder and fruit (increasing food security) (FAO, 2011a). For food security in the short term, provisioning services are crucial, but for future and long-term secure access to food for all, regulatory and supporting services are as important. To target all ecosystem services, a holistic view of the links between ecosystem service delivery and human needs - an ecosystem approach - is required. Thus, restored ecosystems can support a wider range of services, including water management functions that are crucial for stable food security, and become more diverse and more productive (Bennett, et al. 2009). As suggested by Vieira, et al., (2009), Institutionalization may help in extending the management period of natural resources, offsetting some food costs, providing food security for beneficiaries, while involving them in the restoration process. Yet, the major challenge would be to recognize the links between food security, livelihoods and restored ecosystem services. Restoration efforts therefore require greater integration of policies and planning for restoration areas, agriculture and other land uses (FAO, 2011b).

In populated areas the mosaic restoration of a mix of forests, farms and villages (FAO, 2011b); Minnemeyer, et al., 2011) is generally preferable. Minnemeyer and others' world map of forest restoration opportunities considers most of the highland communal areas in Ethiopia to be suitable for mosaic restoration. This case study area is also situated in this area mapped as suitable for mosaic restoration. The findings of this study are also in line with the concept of the Livelihoods and Landscapes Strategy (LLS) designed by Barrow, et al. (2012); where the restored landscapes provide a number of outputs that support the livelihoods of the beneficiaries that depend on them. Accordingly, the study results suggest that the value obtained by sharing only fodder from the 13.26 hectares is US $\$ 158 \mathrm{yr}^{-1}$ which is almost half the 2008 national per capita income. This figure will grow 
to US\$1,022 $\mathrm{yr}^{-1}$ by 2025 , when trees are expected to mature and potentially all restoration outputs deliver maximum economic value. Beside fodder, the outputs delivering this value will include carbon credit and tree volume value. This offers justification that the restoration investment is increasingly rewarding if sustainably managed till maximum economic value is attained (Aronson, et al., 2010; De Groot, et al., 2013). Yet, the realistic tree volume value shared by the beneficiaries after 2025 is only $1 \%$ of the trees, which is stated in the beneficiaries' bylaw. Yet again for the value of the carbon credit to be realized, the small sized restoration area (13.26 hectares) and tonnes of $\mathrm{CO}_{2}\left(1,841\right.$ tonnes $\left.\mathrm{yr}^{-1}\right)$ it sequesters has to join other restored communal areas using 'offset aggregators group'. This is in order that it reaches the carbon credit payment requirement of one sequestration unit each year. As the minimum project size eligible for payments is 500 hectares, one unit or 10,000 metric tonnes of $\mathrm{CO}_{2}$ each year (Locatelli \& Pedroni, 2006; Pearson, et al., 2013; Romero, et al., 2013).

When the 2025 Kanat communal area restoration outputs and economic values are projected to the large-scale 180-hectare communal land holding this will provide the maximum value that beneficiaries could accrue from restoring their total communal area (Table 7). This projection to the large scale was made from the discounted (in order to compare values kanat restoration values from 2025 were discounted to 2008 value) value of Kanat restoration area. This total communal land restoration will apparently provide beneficiaries with the greatest benefit of $U S \$ 7,600 \mathrm{yr}^{-1}$; which is over seven times the maximum economic value of US\$1,022 $\mathrm{yr}^{-1}$ attained from the 13.26-hectare communal area restoration. This is also way beyond the acclaimed government strategic plan to attain middle-income country status with a per capita income of over US\$1,200yr ${ }^{-1}$. Thus, if the benefits from the smallscale site based restoration (Dudley, et al., 2005, Newton, et al., 2012) and the benefits of the large-scale restoration (MEA, 2005; Sayer, et al., 2013) are compared the large-scale restoration approach proves to be imperative to countries like Ethiopia which has lost most of its biodiversity due to environmental degradation (Larjavaara, 2008; Rodrigues, et al., 2011). Observing the reward from large-scale restoration, financial intermediaries can be motivated to extend credit to large-scale restoration activities. Moreover, in order to make the large-scale restoration efforts effective, the engagement of stakeholders (Reed, et al., 2014) through collaborative planning for sustainable management of natural resources has a strong contribution to make. This stakeholder involvement starts from understanding the benefits of such restoration schemes to the livelihoods of beneficiaries specifically and to the country in general. Then all stakeholders take part in the scheme according to their capacity by advocating, monitoring, financing and implementing the restoration (Dewan, et al., 2014). 
As noted by Maginnis and Jackson (2007), active involvement of stakeholders in planning and management decisions is considered to be an essential component of forest landscape restoration. This is to ensure that local needs are adequately addressed, and that the distribution of benefits is equitable in order to gain the support of beneficiaries for the sustainable management of restoration outputs (Guariguata \& Brancalion, 2014). Noted by Newton, et al. (2012) the strong engagement of stakeholders in the implementation of restoration activities through formal community-led initiatives would facilitate and ensure the sustainability of restoration efforts. The legal infrastructure and institutional framework set by beneficiaries in this case study can ensure that the restoration interventions and outputs are sustainable (Sutherland, et al., 2004; Aronson, et al., 2010; De Groot, et al., 2013).

A substantial literature has focused on specifying factors affecting natural resources in communal areas, and what almost all of them have in common are institutional structure, autonomy of institutions and economic incentives (Agrawal, 2001; Blaikie, 2006; Agrawal \& Ostrom, 2007; Dressler, et al., 2010). The success stories have demonstrated how economic benefits from natural resources can be ensured through the institutional structure and capacity (Sheppard, et al., 2010; Gruber, 2011; Leisher, et al., 2012; Measham \& Lumbasi, 2013; Abernethy, 2014); while those dealing with failed projects indicated lack of economic incentives and poor institutional infrastructure as grounds of failure (Blaikie, 2006; Dressler, et al., 2010; Wever, et al., 2012; Dewan, et al., 2014; Crewett, 2015). Some studies have identified how economic incentives complemented by institutional adjustment are an important imperative to restore or preserve natural resources (Dressler, et al., 2010; Leisher, et al., 2012); while other researchers argue the importance of empowering beneficiaries through legal and autonomous entities (Nayak \& Berkes, 2008). In doing so, these researchers stated the importance of starting from raising awareness levels, institutionalizing participatory planning, developing management modality, monitoring and evaluation systems with the beneficiaries which enhance empowerment and ownership of restoration efforts. Accordingly Ethiopia's constitution article 204/2005 permits the legally organized act of interest groups. Based on this framework, the beneficiaries in this case study have established a legal institution with recognized legal rights and procedures. This has provided them the opportunity to collaborate with all stakeholders - government, NGOs and institutions. The legal bylaws developed by these beneficiaries ensured that the resources from the restored areas were managed sustainably (Blaikie, 2006; Measham \& Lumbasi, 2013; Crewett, 2015). Institutionalization also provided the opportunity to involve all beneficiaries and is believed to be the reason for the success of the restoration project (Abernethy, 2014; Crewett, 2015). 
Several studies and research have documented the benefits of different ecosystems and their contributions to socioeconomic welfare and food security (Pimentel, 1997; De Groot, et al., 2002; Richardson, 2008; Poppy, et al., 2014), such as the role of forests and NTFPs in food systems; the complex and diverse linkages between ecosystem services and food security (Richardson, 2010). This case study also documents the benefits of restoration and its linkages to the four pillars of food security as it ensured availability through providing financial resources to beneficiaries to produce or purchase their daily needs. The restoration outputs provided raw materials such as fodder and forage that also contribute to food availability through the production of livestock for meat and dairy consumption (Daily, et al., 1998). The unaccounted services, such as supply of water, soil improvement and erosion control also contribute to food availability to the beneficiaries in the study area or their downstream neighbours (Lal, 2003). The restoration outputs provided a sizable income for beneficiaries to produce, transport and process their food which falls under the accessibility to food (Pattanayak, et al., 2004; Turner, 2010) as the financial income gained from the restored site provided the opportunity for poor households to purchase additional food. The forests of restored areas directly support the utilization of food as tree products can be used for cooking, storage of food and heating. According to Johns and Eyzaguirre (2006) the sustainable management of restored outputs ensures food system stability. Accordingly, the restoration outputs have been legally protected ensuring food system stability for longer periods. 


\section{Conclusion and outlook}

Although many criticize the inadequacy of economic methodologies in accounting for the benefits of ecosystem goods and services, by only valuing marketable ones, it should be noted that such techniques may entail a range of economic instruments and policy mechanisms which can be used to scale up restoration interventions.

The results from this study demonstrated that restoration of communal areas can substantially improve the economic capacity of rural beneficiaries and thereby ensure their food security. This case study further suggests that instead of initiating small-scale restoration initiatives, as in the past; economically viable large-scale landscape restoration initiatives are better, especially when patchy large-scale communal land holdings are widely available in the country.

This case study also indicated that if communal area beneficiaries are institutionalized and given the proper tools and incentives to restore their communal areas, the beneficiaries can effectively ensure their food security and sustain their livelihoods. This is because the process of mandating legitimate beneficiaries by involving them fosters ownership, responsibility and accountability of all stakeholders in restoration and should lead to sustainable food security.

In implementing successful restoration thorough research on the legal, political, institutional, economic, socioeconomic and cultural issues, as well as trade and food prices is imperative. Where these studies are undertaken prior to implementing restoration projects they can offset the challenges to mainstreaming restoration benefits to the community and mechanisms on how to harness and manage these challenges can be designed. They could also inform mobilization approaches that would explore the most appropriate structures to be employed in decision making, bearing in mind the existing stratification within a community. The studies should also point out approaches to the distribution of benefits that will significantly foster the enhancement of restoration management attitudes and contribute to the sustainability of natural resources and livelihoods. 


\section{Acknowledgements}

We would like to thank Richard Babtist, Eco Consulting Group/GTZ, for financial and technical support; and Satishkumar Bellietahtahan for providing valuable inputs to the document.

\section{References}

Abernethy, K.E., Bodin, Ö., Olsson, P.Z., Hilly, Z.A. and Schwarz, A. (2014). 'Two steps forward, two steps back: The role of innovation in transforming towards community-based marine resource management in Solomon Islands'. Global Environmental Change 28:309-321.

Agrawal, A. (2001). 'Common property institutions and sustainable governance of resources'. World Development 29(10), 1649-1672.

Agrawal, A. and Ostrom, E. (2007). 'Decentralization and community-based forestry: Learning from experience. In: Webb, E.L. and Shivakoti, G., (eds) Decentralization, Forests and Rural Communities Policy Outcomes in South and Southeast Asia. Thousand Oaks, CA, USA: Sage, pp.44-67.

Akindele, S.O. and LeMay, V.M. (2006). 'Development of tree volume equations for common timber species in tropical rain forest areas of Nigeria'. Forest Ecology \& Management 226:41-48.

ANRS (2006). Revised Rural Land Administration and Use of the Amhara National Regional State. Proclamation No. 133/2006, ZIKRE HIG 11th Year No. 18. Bahir Dar, Ethiopia: Amhara National Regional State.

ANRS-BoFED (2010). Annual Statistical Bulletin. Bahir-Dar, Ethiopia: Amhara National Regional State Bureau of Finance and Economics Development (ANRS-BoFED), pp.29-50.

Aronson, J., Blignaut, J.N., Milton, S.J., Le Maitre, D., Esler, K., Limouzin, A., Fontaine, C., de Wit, M.W., Mugido, W., Prinsloo, P., van der Elst, L. and Lederer, N. (2010). 'Are socio-economic benefits of restoration adequately quantified? A meta analysis of recent papers (2000-2008) in Restoration Ecology and 12 other scientific journals'. Restoration Ecology 18:143-154.

Babulo, B., Muys, B., Nega, F., Tollens, E., Nyssen, J., Deckers, J. and Mathijs, E. (2009). 'The economic contribution of forest resource use to rural livelihoods in Tigray, Northern Ethiopia'. Forest Policy and Economics 11(2):109-117.

Barrow, E.R., Fisher, R. and Gordon, J. (2012). Improving ecosystem functionality and livelihoods; Epriences in forest landscape restoration and management. Gland Switzerland: IUCN. 
Bekele-Tesemma, A. (2002). Forest landscape restoration initiatives in Ethiopia. Compiled by IUCN-EARO and WWFEARPO.

Bennett, E.M., Peterson, G.D. and Gordon, L.J. (2009). Understanding relationships among multiple ecosystem services. Ecology Letters 12:1394-1404.

Birhanu, A. (2014). 'Environmental Degradation and Management in Ethiopian Highlands: Review of Lessons Learned'. International Journal of Environmental Protection and Policy 2(1): 24-34.

Blaikie, P. (2006). 'Is Small Really Beautiful? Community-based Natural Resource Management in Malawi and Botswana'. World Development 34:1942-1957.

Blignaut, J., Aronson, J. and De Groot, R. (2014). 'Restoration of natural capital: A key strategy on the path to sustainability'. Ecological Engineering 65:54-61.

Blignaut, J., Esler, K.J., de Wit, M.P., Le Maitre, D., Milton, S.J. and Aronson, J. (2013). 'Establishing the links between economic development and the restoration of natural capital'. Current Opinion in Environmental Sustainability 5:94-101.

Blignaut, J., Mander, M., Schulze, R., Horan, M., Dickens, C., Pringle, C., Mavundla, K., Mahlangu, I., Wilson, A., McKenzie, M. and McKean, S. (2010). 'Restoring and managing natural capital towards fostering economic development: Evidence from the Drakensberg, South Africa'. Ecological Economics 69:1313-1323.

Blozan, W. (2008). Tree measuring guidelines of the Eastern Native Tree Society, revised 2008. See ENT website: http:// www.nativetreesociety.org/measure/Tree_Measuring_Guidelines-revised1.pdf [accessed 16 September 2015].

BoARD (2010). Bureau of Agriculture and Rural Development technical report on soil and water management. Bahir Dar, Ethiopia: Amhara National Regional State.

Boonzaaier, C.C. (2012). 'Towards a Community-Based Integrated Institutional Framework for Ecotourism Management: The Case of the Masebe Nature Reserve, Limpopo Province of South Africa'. Journal of Anthropology (2012):530643, $11 \mathrm{pp}$.

Brandeis, T.J., Delaney, M., Parresol, B.R. and Royer, L. (2006). 'Development of equations for predicting Puerto Rican subtropical dry forest biomass and volume'. Forest Ecology and Management 233:133-142.

Burkhart, E.H. and Tomé, M. (2012). Modeling Forest Trees and Stands. New York, USA: Springer.

Butler, B. (2007). 'Calculating accurate aboveground dry weight biomass of herbaceous vegetation in the Great Plains'. In: Butler, B. and Cook, W. (comps) The fire environment - innovations, management, and policy. Conference proceedings, 26-30 March 2007, Destin, FL. Proceedings RMRS-P-46CD. Fort Collins, CO: U.S. Department of Agriculture, Forest Service, Rocky Mountain Research Station, 662pp.

Cao, S., Zhong, B., Yue, H., Zeng, H. and Zeng, J. (2009). Development and testing of a sustainable environmental restoration policy on eradicating the poverty trap in China's Changting County. Proceedings of the National Academy of Sciences of the United States of America 106:10712-10716.

Chave, J.A., Brown, S., Cairns, M.A., Chambers, J.Q., Eamus, D., Folster, H., Fromard, F., Higuchi, N., Kira, T., Lescure, J.P., Nelson, B.W., Ogawa, H., Puig, H., Riera, B. and Yamakura, T. (2005). 'Tree allometry and improved estimation of carbon stocks and balance in tropical forests'. Ecologia 145:87-99. 
Chirwa, P.W. (2014). 'Restoration practices in degraded landscapes of Southern Africa. African Forest Forum', Working Paper Series, Climate and Land Degradation (2)12:44pp.

Chisholm, N. and Woldehanna, T. (2012). Managing watersheds for resilient livelihoods in Ethiopia. Development Cooperation Report. OECD DAC.

Crewett, W. (2015). 'Street-Level Bureaucrats at Work: A Municipality-Level Institutional Analysis of Community-Based Natural Resource Management Implementation Practice in the Pasture Sector of Kyrgyzstan'. Sustainability 7:31463174.

Daily, G.I., Dasgupta, P., Bolin, B., Crosson, P., du Guerny, J. et al. (1998). 'Food production, population growth, and the environment'. Science 281(5381):1291-2.

De Groot, R.S., Blignaut, J., Van Derploeg, S., Aronson, A., Elmqvist, T. and Farley, J. (2013). 'Benefits of Investing in Ecosystem Restoration'. Conservation Biology 27:1286-1293.

De Groot, R.S., Wilson, M.A. and Boumans, R.M.J. (2002). 'A typology for the classification, description and valuation of ecosystem functions, goods and services'. Ecological Economics 41:393-408.

Demeke, T.H. (2011). Assessment of sustainable watershed management approach case study Lenche Dima, Tsegur Eyesus and Dijil watershed. MSc thesis. New York: Cornell University.

Desta, L., Carucci, V., Wendem-Ageňehu, A. and Abebe, Y. (eds) (2005). Community-based participatory watershed development: A guideline. Ministry of Agriculture and Rural Development, Addis Ababa, Ethiopia.

Dewan, C., Buisson, M.C. and Mukherji, A. (2014). 'The imposition of participation? The case of participatory water management in coastal Bangladesh'. Water Alternatives 7(2):342-366.

Dewees, P., Place, F., Scherr, S.J. and Buss, C. (2011). Investing in Trees and Landscape Restoration in Africa: What, Where, and How. Washington, DC: Program on Forests (PROFOR).

Dressler, W., Büscher, B., Schoon, M., Brockington, D., Hayes, T., Kull, C., McCarthy, J. and Streshta, K. (2010). 'From Hope to Crisis and Back? A Critical History of the Global CBNRM Narrative'. Environmental Conservation 37(1):1-11.

Dudley, N.S., Mansourian, S. and Vallauri, D. (2005). 'Forest landscape restoration in context'. In: Mansourian, S., Vallauri, D. and Dudley, N. (eds) Forest restoration in landscapes: Beyond planting trees. Springer, New York: Springer, pp.3-7.

Ejigu, K., Gebey, T., Preston, T.R. (2009). 'Constraints and prospects for apiculture research and development in Amhara region, Ethiopia'. Livestock Research for Rural Development 21(10).

Elias, M. and Potvin, C. (2003). 'Assessing inter and intra specific variation in trunk carbon concentration for 32 neotropical tree species'. Canadian Journal of Forest Research 33:1039-1045.

Ellert, B.H., Janzen H.H. and Entz T. (2002). 'Assessment of a method to measure temporal change in soil carbon storage'. Soil Science Society of America Journal 66:1687-1695.

FAO (2011a). Forests for improved nutrition and food security. Rome, Italy: Food and Agriculture Organization. 
FAO (2011b). The State of the World's Land and Water Resources for Food and Agriculture. Rome, Italy: Food and Agriculture Organization. See: http://www.fao.org/nr/solaw/en/ [accessed 16 September 2015].

Farley, J. (2008). 'The role of prices in conserving critical natural capital'. Conservation Biology 22:1399-1408.

Frank, E.F.(2010). Crownvolumeestimates. See:http://www.nativetreesociety.org/measure/volume/Crown+Volume+Estimates. pdf [accessed 16 September 2015].

Girma, O., Abebe, M.H., Angassa, A. and Weladji, R.B. (2006). 'The role of area enclosures and fallow age in the restoration of plant diversity in northern Ethiopia'. African Journal of Ecology 44(4):507-514.

Gruber, J.S. (2011). 'Article Perspectives of Effective and Sustainable Community-based Natural Resource Management: An Application of Q Methodology to Forest Projects'. Conservation and Society 9(2):159-171.

Guariguata, M.R. and Brancalion, P.H.S. (2014). 'Current Challenges and Perspectives for Governing Forest Restoration'. Forests 2014(5):3022-3030.

Hamilton, K., Sjardin, M., Shapiro, A. and Marcello, T. (2009). Fortifying the foundation: State of the voluntary carbon markets 2009. Ecosystem Marketplace and New Carbon Finance.

Hamilton, K., Sjardin, M., Peters-Stanley, M. and Marcello, T. (2010). Building Bridges: State of the Voluntary Carbon Markets 2010. The Ecosystem Marketplace and Bloomberg New Energy Finance.

Henry, B., McKeon G., Syktus J., Carter J., Day K. and Rayner D. (2007). 'Climate Variability, Climate Change and Land Degradation'. In: Sivakumar, M.V.K. and Ndiang'ui, N. (eds) Climate and Land Degradation, pp.205-221.

Holden, S.T., Benin, S., Shiferaw, B. and Pender, J. (2003). 'Tree Planting for Poverty Reduction in Less-Favoured Areas of the Ethiopian Highlands'. Small-scale Forest Economics, Management and Policy 2(1):63-80.

Johns, T. and Eyzaguirre, P.B. (2007). 'Linking biodiversity, diet and health in policy and practice'. Proceedings of the Nutrition Society 65(02):182-189.

Lal, R. (2003). Food Security and Environmental Quality in the Developing World. Boca Raton, FL: Lewis Publishers/CRC Press.

Larjavaara, M. (2008). 'A review on benefits and disadvantages of tree diversity'. Open Science Forest Journal 1:24-26.

Leisher, C., Hess, S., Boucher, T.M., van Beukering, P. and Sanjayan, M. (2012). 'Measuring the Impacts of Communitybased Grasslands Management in Mongolia's Gobi'. PLoS One 7, e30991.

Lichter, J., Billings, S.A. and Ziegler, S.E. et al. (2008). 'Soil carbon sequestration in a pine forest after 9 years of atmospheric $\mathrm{CO}_{2}$ enrichment'. Global Change Biology 14:2910-2922.

Liu, B.M., Yitayew, A., McHugh, O.V., Collick, A.S., Gebrekidan, B. and Steenhuis, T.S. (2008). 'Overcoming limited information through participatory watershed management: Case study in Amhara, Ethiopia'. Physics and Chemistry of the Earth 33:13-21.

Locatelli, B. and Pedroni, L. (2006). 'Will simplified modalities and procedures make more small[?]scale forestry projects viable under the Clean Development Mechanism?' Mitigation and Adaptation Strategies for Global Change 11(3):621643. 
Maginnis, S. and Jackson, W. (2007). 'What is FLR and how does it differ from current approaches?' In: RietbergenMcCracken, J., Maginnis, S. and Sarre, A. (eds) The forest landscape restoration handbook. London, UK: Earthscan pp.5-20.

Magnussen, S. and Reed, D. (2004). Modelling for estimation and monitoring. FAO-IUFRO.

Malhi Y, Baker TR, Phillips OL, Almeida S, Alvarez E, Arroyo L, Chave J, Czimczik CIA, Di Fiore N, Higuchi TJ, Killeen SG, Laurance WF, Laurance SL, Lewis LM, Montoya A, Monteagudo DA, Neill VP, Nunez S, Patino NC Pitman A, Quesada CA, Silva JNM, Lezama AT, Vasques MR, Terborgh J, Vinceti B, Lloyd J. 2004. The above-ground coarse wood productivity of 104 Neotropical forest plots. Glob Change Biol 10:563-591.

Martens, D., Reedy, T. and Lewis, D. (2003). 'Soil organic carbon content and composition of 130-year crop, pasture and forest land-use managements' Agronomy \& Horticulture Faculty. Paper 124. University of Nebraska. See: http:// digitalcommons.unl.edu/agronomyfacpub/124 [accessed 16 September 2015].

Mbaiwa, J.E. (2009). 'Tourism development, rural livelihoods and biodiversity conservation in the Okavango Delta, Botswana'. In: Hottola, P. (ed.) Tourism Strategies and Local Responses in Southern Africa. Oxford, UK: CABI.

MEA (Millennium Ecosystem Assessment) (2005). 'Ecosystems and human wellbeing: multiscale assessments'. In: Synthesis Report Series, vol. 4. Washington, DC: Island Press.

Measham, T.G. and Lumbasi, J. (2013) 'Success factors for Community Based Natural Resource Management (CBNRM): Lessons from Kenya and Australia'. Environmental Management 52(3):649-659.

Mekuria, W., Veldkamp, E., Tilahun, M. and Olschewski, R. (2011). 'Economic valuation of land restoration: The case of exclosures established on communal grazing land in Tigray, Ethiopia'. Land Degradation and Development 22(3):334344.

Mekuria, W. and Aynekulu, W. (2013) 'Exclosure land management for restoration of the soils in degraded communal grazing lands in northern Ethiopia'. Land Degradation and Development 24:528-538.

Minnemeyer, S., Laestadius, L., Sizer, N., Saint-Laurent, C. and Potapov, P. (2011). Global Map of Forest Landscape Restoration Opportunities. Global Partnership on Forest Landscape Restoration. World Resources Institute, International Union for Conservation of Nature and South Dakota State University. See: http://www.wri.org/resources/maps/globalmap-forest-landscape-restoration- opportunities [accessed 16 September 2015].

Muna, M., Elhag, E. and Walker S. (2009). 'Impact of Climate Change and the Human Activities on Land Degradation in Arid and Semi-arid Regions'. Nile Basin Water Engineering Scientific Magazine, vol. 2, 2009.

Nayak, P. and Berkes, F. (2008). 'Politics of co-optation: Community forest management versus joint forest management in Orissa, India'. Environmental Management 41:707-718.

Nedessa, B., Ali, J. and Nyborg, I. (2005). Exploring ecological and socio-economic issues for the improvement of area enclosure management: A case study from Ethiopia. Drylands Coordination Group Report No. 38, 63pp.

Nelson, F. and Agrawal, A. (2008). 'Patronage or participation? Community-based natural resource management reform in sub-Saharan Africa'. Development and Change 39(4):557-585.

Newton, A.C., del Castillo, R.F., Echeverría C., et al. (2012). 'Forest landscape restoration in the drylands of Latin America'. Ecology and Society 17(1):21. 
Oliveras, I., van der Eynden, M., Malhi, Y., Cahuana, N., Menor, C., Zamora, F., Haugaasen, T. (2014). 'Grass allometry and estimation of above-ground biomass in tropical alpine tussock grasslands'. Australian Ecology 39:408-415.

Pandey, D. (1983). Growth and yield of plantation species in the tropics. Rome, Italy: Food and Agriculture Organization.

Pattanayak, S.K., Sills, E.O. and Kramer, R.A. (2004). 'Seeing the forest for the fuel'. Environment and Development Economics 9:155-179.

Pearson, T., Brown, S. and Ravindranath, N.H. (2005). Integrating carbon benefit estimates into GEF projects, capacity development and adaptation group guidelines. UNDP-GEF, Winrock International, Arlington, Virginia, USA.

Pearson, T., Walker, S. and Brown, S. (2013). Sourcebook for land use, land-use change and forestry projects. Washington, DC: World Bank. See: http://documents.worldbank.org/curated/en/2013/01/18009480/sourcebook-landuse-land-use-change-forestry-projects [accessed 16 September 2015].

Pimentel, D., McNair, M., Buck, L., Pimentel, M. and Kamil, J. (1997). 'The value of forests to world food security'. Human Ecology 25:91-120.

Poppy, G.M.S., Chiotha, F., Eigenbrod, C., et al. (2014). Food security in a perfect storm: Using the ecosystem services framework to increase understanding. Philosophical Transactions of the Royal Society B 369: 20120288. See: http:// dx.doi.org/10.1098/rstb.2012.0288 [accessed 16 September 2015].

Poteete, A.R. (2009). 'Defining political community and rights to natural resources in Botswana'. Development and Change 40(2):281-305.

Preminger, A. and Wettstein, D. (2005). 'Using the penalized likelihood method for model selection with nuisance parameters present only under the alternative: An application to switching regression models'. Journal of Time Series Analysis 26:715-741.

Pretzsch, H. (2010). Forest dynamics, growth and yield. From measurement to model (7th ed.) Berlin, Heidelberg: Springer.

Rautiainen, M., Mõttus, M., Stenberg, P. and Ervasti, S. (2008). 'Crown envelope shape measurements and models'. Silva Fennica 42(1):19-33.

Reed, J., Deakin, L. and Sunderland, T. (2014). "What are "Integrated Landscape Approaches" and how effectively have they been implemented in the tropics: A systematic map protocol'. Environmental Evidence 4:2.

Rees, W., Farley, J., de Groot, R.S. and Vesely, E. (2007). Valuing Natural Capital and the Costs and Benefits of Restoration. Washington, DC: Island Press.

Richardson, R.B. (2008). 'Conceptualizing the value of ecosystem services in deserts'. In: Chapman, R.L. (ed.) Creating Sustainability within Our Midst. New York: Pace University Press, pp.225-248.

Richardson, R.B. (2010). 'Ecosystem Services and Food Security: Economic Perspectives on Environmental Sustainability'. Sustainability 2:3520-3548.

Rodrigues, R.R., Gandolfi, S., Nave, A.G., Aronson, J., Barreto, T.E., Vidal, C.Y. and Brancalion, P.H.S. (2011). 'Largescale ecological restoration of high-diversity tropical forests in SE Brazil'. Forest Ecology and Management 261(10):16051613. 
Romero, M.Z., Trærup, S., Wieben, E., Møller, L.R. and Koch, A. (2013). Economics of Forest and Forest Carbon Projects. Translating Lessons Learned into National REDD+ Implementation. Report for United Nations Environment Programme (UNEP) Riso Centre. Nairobi, Kenya: UNEP and UN-REDD.

Sachs, J.D. and Reid, W.V. (2006). 'Investments toward sustainable development'. Science 312:1002.

Sayer, J., Sunderland, T., Ghasoulc, J., Pfund, J.L., Sheilb, D., Meijaard, E., Ventera, M., Boedhihartonoa, A.K., Day, M., Garcia, C., et al. (2013). 'Ten principles for a landscape approach to reconciling agriculture, conservation, and other competing land-uses'. PNAS 110:8349-8356.

Sheppard, D.J., Moehrenschlager, A., McPherson, J.M. and Mason, J.J. (2010). 'Ten years of adaptive communitygoverned conservation: Evaluating biodiversity protection and poverty alleviation in a West African hippopotamus reserve'. Environmental Conservation 37:270-282.

Sutherland, W., Pullin, A., Dolman, P. and Knight, T. (2004). 'The need for evidence-based conservation'. Trends in Ecology and Evolution 19:305-308.

TEEB (2010). The economics of ecosystems and biodiversity: Ecological and economic foundations. Kumar, P. (ed.). London and Washington, DC: Earthscan.

Teklay, T. and Chang, S.X. (2008). 'Temporal changes in soil carbon and nitrogen storage in a hybrid poplar chronosequence in northern Alberta'. Geoderma 144(3-4):613-619.

Turner, B.L., II. (2010). Vulnerability and resilience: Coalescing or paralleling approaches for sustainability science? Global Environmental Change 20(4):570-576.

Vanclay, J.K. (1994). Modelling Forest Growth and Yield: Applications to Mixed Tropical Forests. Wallingford, UK: CABI.

Vieira, D.L.M., Holl, K.D. and Peneireiro, F.M. (2009). 'Agro-Successional Restoration as a Strategy to Facilitate Tropical Forest Recovery'. Restoration Ecology 17:451-459.

Walkley, A.J. and Black, C.A. (1934). 'An examination of the Degtjareff method for determining soil organic matter and a proposed modification of the chromic acid titration method'. Soil Science 37(1):29-38.

Walkera, S., Pearson, T., Munishib, P. and Petrovaa, S. (2008). Carbon market opportunities for the forestry sector of Africa. Winrock International and FAO in support of the 16th Session of the African Forestry and Wildlife Commission, Khartoum, Sudan.

Wang, C., Yang, Y. and Zhang, Y. (2011). 'Economic development, rural livelihoods, and ecological restoration: Evidence from China'. Ambio 40:78-87.

Wehkamp, J., Devlin, S. and Williams, C. (2013). Ownership models for sustainable natural resource governance. Working paper, New Economics Foundation.

Wever, L., Glaser, M., Gorris, P. and Ferrol-Schulte, D. (2012). 'Decentralization and participation in integrated coastal management: Policy lessons from Brazil and Indonesia'. Ocean and Coastal Management 66:63-72.

Wiggins, S., Marfo, K. and Anchirnah, V. (2004). 'Protecting the forest or the people? Environmental policies and livelihoods in the forest margins of Southern Ghana'. World Development 32:1939-1955. 
Yayneshet, T. (2011). 'Restoration of Degraded Semi-Arid Communal Grazing Land Vegetation Using the Exclosure Model'. International Journal of Water Resources and Arid Environments 1(5):382-386.

Yitbarek, T.W., Belliethathan, S. and Masresha, F. (2010). 'A Cost-Benefit Analysis of Watershed Rehabilitation: A Case Study in South Gondar, Ethiopia'. Ecological Restoration 28(1):46-55.

Yitbarek, T.W., Belliethathan, S. and Stringer, L.C. (2012). 'The onsite cost of gully erosion and cost-benefit of gully rehabilitation: A case study in Ethiopia'. Land Degradation and Development 23:157-166. 


\section{Evidence-based best practice}

community-based forest restoration in Biliran: Integrating food security and livelihood improvements into watershed
rehabilitation in the Philippines

Nestor Gregorio, ${ }^{1,2}$ John Herbohn, ${ }^{1,2}$ Steve Harrison, ${ }^{1,2}$ Arturo Pasa, ${ }^{3}$ Jufamar Fernandez, ${ }^{3}$ Rogelio Tripoli ${ }^{3}$ and Bonifacio Polinar ${ }^{4}$

1 Tropical Forests and People Research Centre, University of the Sunshine Coast, Locked Bag, Maroochydore DC, Australia 


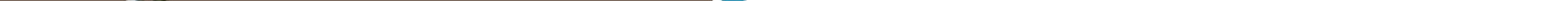




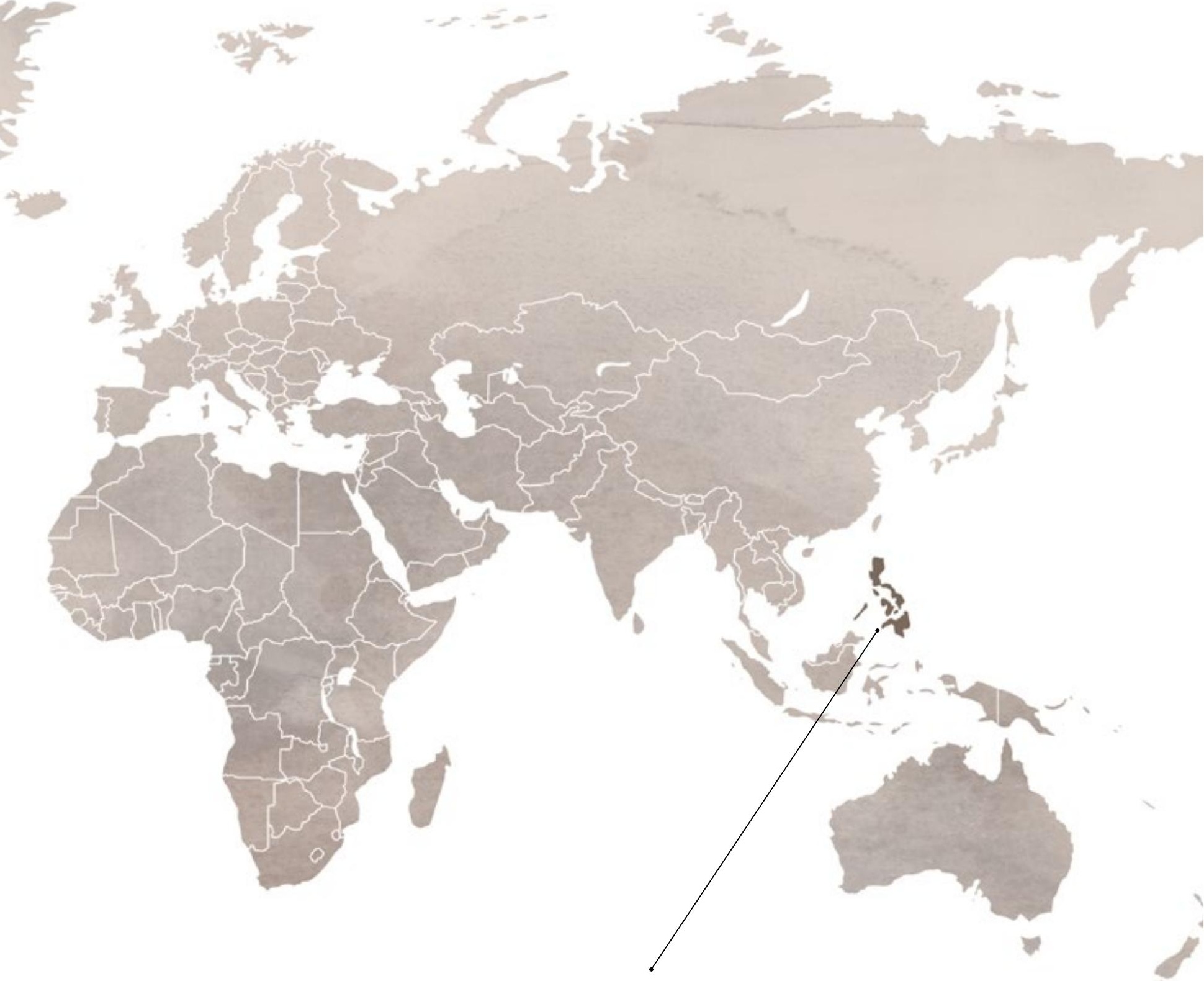

Philippines

Country in Asia

Size: cca 300,000 km²

Population: 98.39 million (2013, World Bank)

Capital: Manila 


\section{Introduction}

The negative impacts of population growth on global forest cover and subsequent effects of forest loss to the environment and people are widely reported. Issues of poverty and lack of food security are widely recognized as among the major causal factors of deforestation in many developing countries (Ekoko, 1996; Deininger \& Minten, 1996; Amacher, et al., 1998; Ptaff, et al., 2004; Le, et al., 2012; Sikor, et al., 2013). Various initiatives have been developed in many countries to combat deforestation, reduce poverty, enhance food security, and promote climate change mitigation and adaptation. In September 2011, leaders from around the world launched the Bonn Challenge in Germany. This 'challenge' is a global aspiration to restore 150 million hectares of the world's degraded lands by 2020 , adopting the forest landscape restoration approach (IUCN, 2015). The concept of FLR goes beyond usual reforestation programmes; it is not simply about restoring ecological integrity but also enhancing human wellbeing in deforested and degraded landscapes. The IUCN (2015) emphasized that FLR accommodates various land uses in a given landscape including production and protection forestry, agriculture and agroforestry. The success of FLR relies on the active involvement of stakeholders, including upland communities, in restoring the function and productivity of denuded forests and degraded lands.

The people-oriented approach in forest management has been adopted in many countries in Asia. Generally known as community forestry, this approach involves people in communities working together to establish tree plantations or manage existing stands while simultaneously planting fruit trees and agricultural crops to satisfy food requirements and livelihood (FAO, 1978). In this approach, socioeconomic benefits and food security are the key motivations for people to work as a group to conserve biodiversity and manage their forest sustainably (Sikor, et al., 2013). The community-based forestry context strongly aligns with the principles of FLR, which makes this a promising strategy to help achieve the Bonn Challenge.

In the Philippines, community forestry has been the major government strategy to promote sustainable development in the uplands for around four decades. It is associated with efforts to reforest heavily degraded former forest areas and provide improved livelihoods and food security for impoverished upland communities. There have been many programmes under various banners but most of the earlier people-based programmes were brought under the Community Based Forest Management Program (CBFMP) in 1995. While 
CBFMP is regarded as the ultimate strategy to rehabilitate denuded uplands and manage the remaining forest in a sustainable way (Guiang, et al., 2001), implementation is complex and difficult. Pulhin (2007) observed that the objectives of community forestry, including poverty alleviation and sustainable management of forest resources, are far from being realized. The assessment of Le, et al. (2014) on the success of reforestation programmes in the Philippines revealed a similar result. The failure to sustain livelihood projects, lack of financial incentives especially during the early stage of programme implementation, and failure to address food security issues are major factors that limit the success of communitybased forestry programmes in the country (Estoria, 2004; Carandang, et al., 2010).

As part of a continuing research programme, ASEM/2010/050 (referred to as the Watershed Rehabilitation Project) of the Australian Centre for International Agricultural Research (ACIAR) in the Philippines, an evidence-based best-practice watershed rehabilitation project has been developed to address the key deficiencies of the previous community-based reforestation programmes. The evidence is drawn from a series of ACIAR-funded forestry research projects in the Philippines over 15 years, and lessons learned from past people-based reforestation programmes in the country. This paper discusses the process of developing the project and presents the initial results of pilot testing the interventions. 


\section{Restoration context and research questions}

This section provides background information about deforestation in the Philippines. A contextual description of the case study site is also provided and relevant forest restoration interventions are discussed. The research questions addressed in the case study are also presented.

\section{Deforestation in the Philippines}

The massive degradation of natural resources in upland areas of the Philippines has resulted in adverse socioeconomic and ecological consequences including widespread poverty, accelerated soil erosion, massive flooding and a tremendous decline in biodiversity (Lasco, et al., 2001). In an attempt to reverse this trend, the national government and development assistance agencies have been implementing watershed rehabilitation programmes for many years. The strategies have evolved continuously in response to scientific investigations, experience, successful results and failures (Pulhin, 1997).

It was estimated that in 1900, about $95 \%$ of the 30 million hectares total land area of the Philippines was covered with lush tropical rainforest (Uitamo, 1996). However, massive logging of dipterocarp forests reduced the forest cover to about $50 \%$ of the total land area by 1940 (Bautista, 1990). It was during this period that the Philippines became the largest exporter of timber in Southeast Asia (Tucker, 1988). In 1950, there was about 49\% forest cover, which was further reduced to $22 \%$ in 1987. From 1980 to 1990, around 316,000 hectares of forest were lost, equivalent to $3.5 \%$ of the country's forest cover (ADB, 1994). In 1995, the forest cover had shrunk further to 5.6 million hectares (19\%), of which only 0.8 million hectares was old growth forest. FAO (1997) reported an annual forest loss of 262,000 hectares between 1990 and 1995. In 1996 the Philippine Forestry Statistics indicated a further reduction in the remaining forest to 5.4 million hectares (18\%) in addition to 10.5 million hectares of open, degraded or occupied forest areas (Sajise, 1998). Heaney et al. (1997) argues that the massive decline of forest area in the Philippines in less than a century is probably the most rapid and severe in the world. From being a large-scale timber-exporting country in the mid-1900s, the Philippines became a major timber importer near the end of the century. 
The rate of decline of forest cover from 1934 to 2010 is summarized in Table 1. It was only in 2003 that the decline in forest cover was reversed (up 11\% from 1988). According to Pulhin, et al. (2006), this improvement of forest cover was attributed to the efforts of the Department of Environment and Natural Resources (DENR) in slowing down commercial logging through a logging moratorium, shift in logging from old growth to second growth forest, bans on lumber and log exporting, public and private reforestation efforts, and adoption of the Community-Based Forest Management Program for forest rehabilitation and management of forestlands. However, the latest assessment of forest cover, in 2010, indicated a forest cover reduction of over 300,000 hectares from the 2003 record. Although it is apparent that the national forest cover has increased during the last two decades, there remain about 10.3 million hectares of uplands in various degrees of deforestation that need to be rehabilitated (DENR, 2015).

Table 1.

Forest cover of the Philippines, 1934-2010

\begin{tabular}{ccc} 
Year & Forest cover (\%) & $\begin{array}{c}\text { Percentage forest cover relative to land area } \\
\text { (million hectares) }\end{array}$ \\
\hline 1934 & 17.18 & 57.3 \\
\hline 1941 & 17.24 & 57.5 \\
\hline 1969 & 10.00 & 33.3 \\
\hline 1976 & 8.10 & 27.0 \\
\hline 1980 & 7.40 & 24.7 \\
\hline 1988 & 6.46 & 21.5 \\
\hline 2003 & 7.17 & 23.9 \\
\hline 2010 & 6.84 & 22.8 \\
\hline
\end{tabular}

Source: Pulhin, et al., 2006; DENR, 2015.

Deforestation in the Philippines is closely linked to poverty (Borlagdan, et al., 2000; Contreras-Hermosilla, 2000; Guiang, et al., 2001) The rapid growth of the Philippine population has been associated with increasing poverty and landlessness, which prompted rapid upland migration. Industrial logging firms felled large areas of forest in the 1980s, and upland migration is now placing pressure on the remaining forest. With the absence of, or inadequate, economic opportunities, poor and landless families are compelled to encroach government-managed forest areas and cultivate the highly fragile uplands in order to meet their food and other subsistence needs (Cabrido, 1985; Guiang, et al., 2001; Emtage, 2004). Approximately 24 million people conduct subsistence farming (slash and 
burn) inside the forestland and this number is continuously increasing due to poverty that remains a critical social problem in the country (Espiritu, et al., 2010). According to Jensen (2003), unsustainable slash-and-burn farming in forest communities has accounted for $60 \%$ of forest denudation in recent years. Slash-and-burn farming was also identified as the cause of most forest fires, which caused $72.9 \%$ of the forest loss from 1980 to 2001 (Rebugio, et al., 2007).

Realizing the importance of involving forest communities in managing forest resources, the Philippine Government shifted its forest management direction in 1995, to favour community forestry. Under this paradigm, the social and economic aspects of watershed management are given higher priority in watershed rehabilitation programmes. This integrated concept has expanded to address community needs and problems - and particularly poverty, food insecurity and unsustainable livelihoods - as part of a holistic watershed management development system.

\section{Contextual description of the study site}

The Philippines is one of the largest group of islands in the world, and an important trading partner and neighbour country of China (Taiwan), Brunei Darussalam, Viet Nam and Malaysia (Figure 1). Archipelagic in nature, the country is composed of 7,107 islands covering a total land area of $300,780 \mathrm{~km}^{2}$ (Kerr, et al., 2000). Groups of islands are further divided into regions, which in turn are divided into provinces. The provinces are divided into cities and in turn to municipalities. The cities and municipalities are further divided into barangays. As of September 2014, the Philippines has 17 regions, 81 provinces, 144 cities, 1,490 municipalities and 42,029 barangays (Bersales, 2015). In 2010, the population was estimated to be 92.3 million with a population density of 308 persons $/ \mathrm{km} 2$. Over half of the population (54.7\%) live in rural areas and approximately $75 \%$ depend on agriculture as their primary source of livelihood (NSCB 2015).

Since 1919, the Philippine Government has classified land by slope for management purposes. All land having a slope of $18 \%$ or more is classified as forestland (also called public land) and managed by the DENR. Land with a slope of less than $18 \%$ is categorized as alienable and disposable, which can be privately acquired and titled (Emtage, 2004). However, the forestland classification is not reflective of the actual forest cover, because in reality most forestland has no trees, and is used predominantly for agriculture. Jensen (2003) stated that of the total land area of the Philippines, about 15.9 million hectares are classified as forestland or public land, which is further categorized into timberland, forest reserve, national parks, and military and civil reservations. Out of 10 million hectares classified as timberland, around 5 million are under various types of community-based 
management while the rest are under co-management schemes of the DENR and the private sector.

The site selected for the pilot watershed rehabilitation project is a 26-hectare upland area in Barangay Kawayanon, a community in the municipality of Caibiran, Biliran Province (Biliran Island). Biliran Province is one of the six provinces comprising Region VIII. It is a

Figure 1.
Location of the
case study site

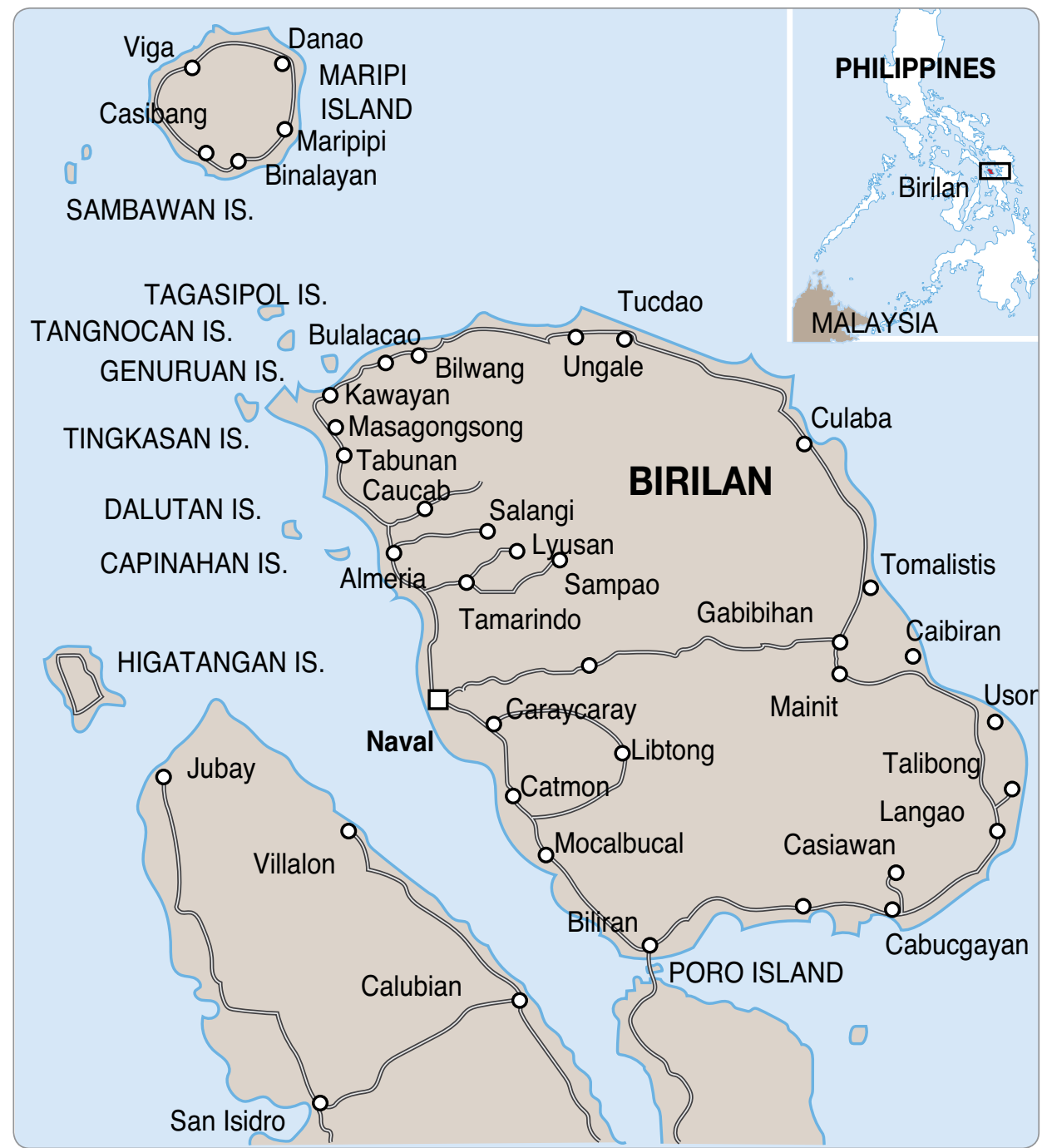

Sources: Owl \& Mouse, 2015; Gooddive.com, 2015. 
volcanic island composed of eight municipalities, with Caibiran as one of the only two municipalities with wide plains that are suitable for agriculture. The climate is characterized as having no distinct dry season and heavy rains occurring in December making it ideal for agricultural production (LGU-Biliran, 2015).

The municipality of Caibiran is the innermost town of Biliran Island. It is known for its rivers, waterfalls and hot springs, which attract both locals and tourists. The NSCB (2013) indicates that Caibiran has the highest poverty incidence (38.3\%) of the eight municipalities comprising Biliran Province. The pilot community-based watershed rehabilitation project is being undertaken in Kawayanon, one of the 17 barangays of Caibiran.

Kawayanon was once densely forested but experienced severe forest loss, erosion and land degradation due to logging in the 1960s and subsequent encroachment by slashand-burn farmers (Polinar, 2015). About 90\% of the natural forest was lost and smallholder illegal logging continues to reduce the remaining patches of natural forest. The community is basically situated in volcanic and undulating land that largely belongs to the timberland category. The upland is mainly composed of grassland, dominated by Imperata cylindrica with a mosaic of shrubs, including Chromolaena odorata and Lantana camara, and a few trees that are remnants of previous reforestation projects. There are patches of coconut plantations, smallholder kaingin (slash-and-burn) farms in which farmers have planted agricultural crops for subsistence, and a small remnant of natural forest (Figure 2). The land has been planted with trees under several national government reforestation projects. The community holds a Community-Based Forest Management Agreement (CBFMA), a tenurial

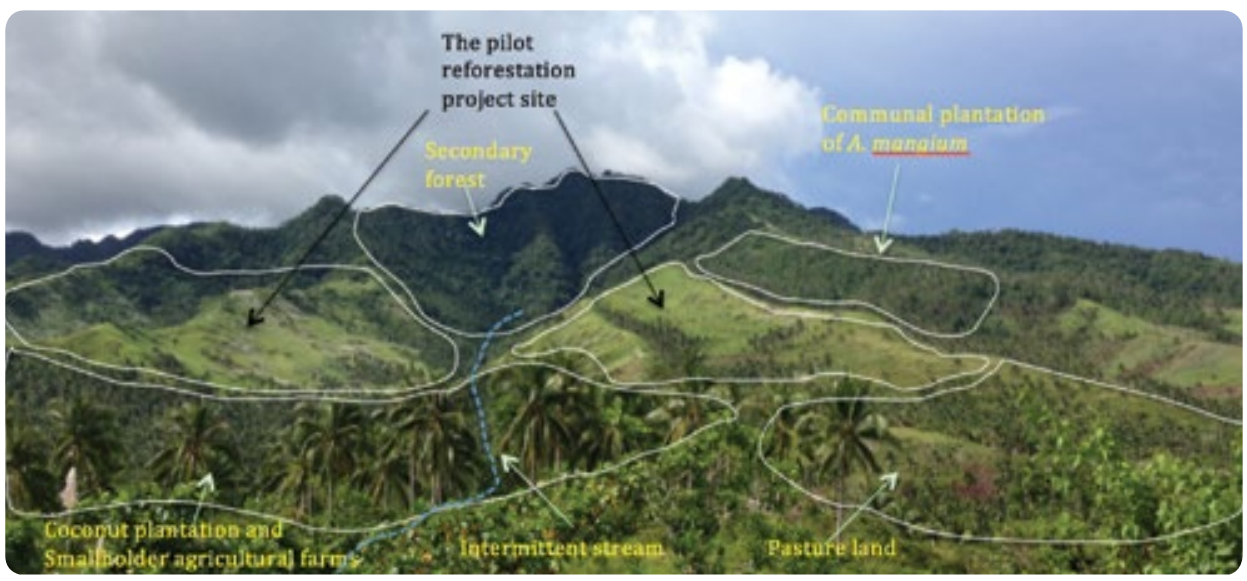

Figure 2.

The site of the pilot community-based reforestation project and adjacent land use (photo credit: Nestor Gregorio) 
instrument providing the right to develop, use and manage 100 hectares timberland for 25 years and with the possibility of renewal for another 25 years subject to appropriate management. Despite the multiple reforestation projects in the area, tree stocking remains less than $10 \%$. Fruit trees were planted as part of the reforestation programme but the grafted seedlings have had a low survival rate.

The case study site has been characterized by unfavourable conditions for forestry, including rugged landscape, steep slopes, severe soil erosion, infertile soil and windaffected ridges. The soil is relatively shallow, with frequent isolated landslides posing a high risk to communities located at the base of a mountain. The area has been used for grazing with deliberate burning to produce palatable shoots for ruminants. Uncontrolled fires from kaingin farms and deliberate burning by land claimants due to disputes over land have also been reported.

The community in the case study site is very poor, with substantial food security issues and virtually no cash earning opportunities. Smallholder farming including slash-and-burn agriculture is the major source of income and food for most families. Some residents earn income from selling firewood and working as labourers outside the community. The area has many adverse claimants over land rights. A dysfunctional people's organization (PO) named Kawayanon Farmers Association Incorporated (KFAl) represents the community's interests with only three active members still remaining out of 118 initial members.

\section{Relevant forest restoration interventions in the case study site}

The case study site has been subjected to several layers of government-funded reforestation projects under various programmes including the Contract Reforestation Project (CRP) of the National Forestation Program, the Community-Based Forest Management Program (CBFMP), the Upland Development Program (UDP) and, most recently, the National Greening Program (NGP). The following provides an overview of the performance of these programmes, as they were implemented in the site.

\section{The Contract Reforestation Project}

In the 1980s, the site was planted with Acacia mangium through the Contract Reforestation Project of the National Forestation Program. A PO was formed by the DENR to establish a contract to reforest the area within a three-year period. Part of the agreement was to turn the plantation over to the DENR after this period. The reforestation project was implemented and managed only by the PO officers. Most PO members and 
other residents of the community were only involved as labourers in seedling production and tree planting. One-off training sessions were carried out on seedling production and plantation establishment but no livelihood and food security projects were provided for the community. The community was compensated for providing labour for the implementation of the project.

\section{Implementation of the Community-Based Forest Management Program}

The CBFMP was formed in 1995 following the recognition of the linkages between forest, sustainability and poverty. It was designed to address the shortcomings of previous reforestation programmes, forging strong partnership with communities and empowering them to become effective partners in sustainable development. Previous people-based reforestation programmes were subsumed under the CBFMP.

A new PO named KFAl was formed in the community during the implementation of CBFMP because the previous group formed during the CRP was disbanded. KFAl formed part of a federation of POs in the municipality of Caibiran named the Community Forestry Program Beneficiaries Association (CFPBA). The PO was awarded the CBFMA to develop the 100-hectare timberland by planting trees and agricultural crops, utilizing the site's resources and managing the project site to promote sustainability. The CBFMA's duration was for 25 years and renewable for another 25 years. Substantial funds were allotted by the DENR for community organization, capacity-building activities and seedling production, as well as plantation establishment, maintenance and protection. Funds were also provided for the implementation of livelihood projects to help address financial needs and provide food security for the PO members.

A combination of biophysical, socioeconomic, policy and governance issues contributed to the failure of the CBFM project in Kawayanon. The PO disbanded when project funds were exhausted, the livelihood projects did not survive and plantations were left without post-planting silvicultural treatments resulting in major loss of trees due to forest fire, grazing, illegal cutting and conversion of the site to kaingin and suppression of trees by overtopping grasses and shrubs.

\section{Initiatives of the Upland Development Program}

In 2009, the UDP was implemented in the Philippines to increase the income of upland farmers and mitigate hunger, while also enhancing the country's capacity to adapt to climate change. The objective of the UDP was to create jobs for farmers in upland and 
coastal areas. The Philippines Government allotted US\$30 million for the implementation of this programme. The DENR partnered with POs engaged in community-based forest and resource management programmes.

The KFAI was a recipient of UDP funding. Although the PO was the implementing body in the contract, implementation followed a family approach wherein family members of the organization with land (tenured or untenured) were given support. Each family was provided with farm inputs including seedlings for fruit trees and fertilizer. A cash incentive of US\$ 500/ha was provided to farmers to pay for their labour in establishing the plantation. It was envisaged that this strategy would enable farmers to devote all their time to the rehabilitation of the environment while earning money in the process. There was no training programme to enhance farmers' skills in the silviculture of timber and fruit trees, and no long-term livelihood projects were established for the PO. The direct benefits to KFAl members consisted of wages for their labour in planting and managing the seedlings and the fruit harvested from the trees several years after planting.

Like previous reforestation initiatives on the site, the UDP did not succeed. About 90\% of the fruit and timber tree seedlings died. Reports revealed that funds provided for planting the seedlings and maintaining the plantation were spent for other purposes. There was no consultation with the community regarding species selection. Some of the fruit trees provided by the DENR did not match farmers' preferences. The handout nature of the UDP scheme failed to include necessary support measures such as the capacity building for recipients, a long-term livelihood component and appropriate auditing of project operations.

\section{Undertaking the National Greening Program}

In February 2011, Philippines President Benigno Aquino III issued Executive Order 26 declaring the implementation of the NGP, a government priority programme to: reduce poverty; promote food security, environmental stability and biodiversity conservation; and enhance climate change mitigation and adaptation. This programme aims to plant 1.5 billion seedlings covering 1.5 million hectares between 2011 and 2016. In line with the government's community-based approach to natural resource management, the NGP has primarily involved community organizations engaged in CBFM projects. The programme does not have funds for community organizing and has minimal financial resources for capacity building because participating communities were believed to have been empowered already and possess the appropriate knowledge and skills to implement a community-based reforestation project. The POs are expected to manage the plantations once the term of the NGP support ends because the plantations are located inside their CBFM areas. 
The KFAI, through a CBFMA, entered into a contract with the DENR to reforest 100 hectares of land in Kawayanon under the NGP. The area is located inside the CBFM site of the PO. Funds for seedling production and plantation establishment and maintenance for three years were provided to the organization. Although the project bears the name of the organization, in reality only the prominent PO officials became involved in the new NGP projects. The other former members are used as labourers, creating a scenario that harks back to the much-criticized CRP. Unlike the CBFMP, there are no specific funds for livelihood projects in the NGP. Members of KFAl obtain payment for labour in various project activities including seedling production and plantation establishment, maintenance and protection.

Assessment of the NGP plantation in 2013 revealed a seedling survival rate of only $21.5 \%$. The plantation was damaged by fire three times between 2011 and 2013, and there was suspicion that local residents and land claimants intentionally started the fires. During each incident, only the three members of the PO and their family members attempted to suppress the fire, failing each time. In this case, the essence of community participation is absent. The lack of community participation adversely affected the management of the plantation when financial support for the project ceased.

The above interventions are attempts to reforest the upland of Kawayanon as part of the national drive to rehabilitate denuded forests in the Philippines. The approaches and methodologies of these programmes have evolved through time in response to scientific investigations, experience, and lessons learned from previous reforestation endeavours. For example, the failure of the CRP to address the socioeconomic aspect of forest rehabilitation and management paved the way for the adoption of community-based forestry. However, despite a shift in approach to involve communities in forest rehabilitation and management, the site remains barren and degraded. Also, there is little evidence of improved socioeconomic conditions of the community as a benefit of undertaking the reforestation projects.

The failure of the reforestation programmes in Kawayanon is repeated in most regions in the Philippines and elsewhere in the world. While a number of studies have revealed the factors for the limited success of people-based forestry, very little attempt has been made to design and implement reforestation programmes which take into account the multitude of lessons from reforestation failures. It is to address this need that the pilot watershed rehabilitation project was initiated. 


\section{Research questions}

The case study of the ACIAR watershed rehabilitation project discusses:

- Pilot testing best practice in designing, implementing and monitoring a communitybased watershed rehabilitation programme;

- Developing a package of intervention measures to promote the success for a community forestry programme in the Philippines and other similar tropical countries; and

- Identify further lessons that can be learned throughout the implementation process.

The study aims to answer the following research questions:

1. How can a community-based watershed rehabilitation programme be designed that will effectively address the shortcomings of previous community-based reforestation initiatives?

2. What are the best approaches to implementing a watershed rehabilitation programme that will result in the sustainable development of forest resources and long-term food security of upland communities?

3. What are the best-practice technologies in watershed rehabilitation given the adverse biophysical conditions of the planting site and socioeconomic characteristics of smallholder upland farmers? 


\section{Implications for improved community-based forest restoration projects}

Community-based forestry is widely perceived as the most appropriate strategy for effective forest restoration and sustainable development of forest resources. However, most of the community-based reforestation and watershed management programmes in the Philippines have failed to address food shortage and improve the socioeconomic status of upland communities (Guiang, et al., 2001; Eslava, 2004). A plethora of biophysical, socioeconomic and policy and governance issues and problems limit the effectiveness and sustainability of community-based forestry projects in most regions. These issues and problems are typically found across community forestry projects across the Philippines (Guiang, et al., 2001; Estoria, 2004; Rebugio, et al., 2007; Le, et al., 2012; Israel \& Lintag, 2013). Thus, there is a clear need to develop an improved community-based reforestation programme, which takes on board the lessons from past community-based interventions. This section discusses the process of designing and implementing the pilot watershed rehabilitation project - this is evidence-based, participatory and emphasises food security as a strategy to promote successful forest landscape restoration.

\section{Designing the pilot watershed rehabilitation project}

The design of the pilot watershed rehabilitation project draws on the results and experience of the Philippine Government's reforestation programmes including those reported in Guiang, et al., 2001; Eslava, 2004; Pulhin, et al., 2007; Carandang, et al., 2010 and Israel \& Lintag, 2013. The design also draws on the findings of substantial past research activities undertaken as part of a series of ACIAR smallholder forestry projects in the Philippines including: the assessment of past reforestation plantings to identify drivers of success (Le, et al., 2012,2014 \& 2015; Herbohn, et al., 2014); design and implementation of a local and national tree nursery accreditation programme (Gregorio, et al., 2008 \& 2015); silviculture of key species and mixed species plantations (Gregorio, et al., 2012; Nguyen, et al., 2012, 2014a \& 2014b); research into forestry extension methods (Baynes, et al., 2011a 
\& 2011b); and community dynamics, policy, social capital and livelihood issues (Harrison, et al., 2008; Thomas, et al., 2010; Baynes, et al., 2014). The project design is also informed by empirical data obtained from stakeholders including members of the PO in the case study area, other community residents and officials of the DENR.

The project adopts the systems approach, which takes into account social, economic, biophysical, policy and governance aspects in forest landscape restoration. This contrasts with the reductionist approach followed in implementing several other reforestation programmes in the Philippines. For example, watershed rehabilitation programmes are often biased towards the establishment of plantations with little emphasis on improving the socioeconomic conditions of upland communities, promoting food security or creating a favourable policy environment. Also, the success of reforestation programmes is largely measured on the survival rate of seedlings while neglecting a plethora of factors especially those relating to the social component of the programme and its environmental impacts. A meta-analysis of factors influencing the success or failure of community forestry groups (Figure 3) was used to guide the design of the pilot community-based watershed rehabilitation project.

Figure 3.

Relationship between the factors influencing the success or failure of community forestry groups based on meta-analysis of the literature

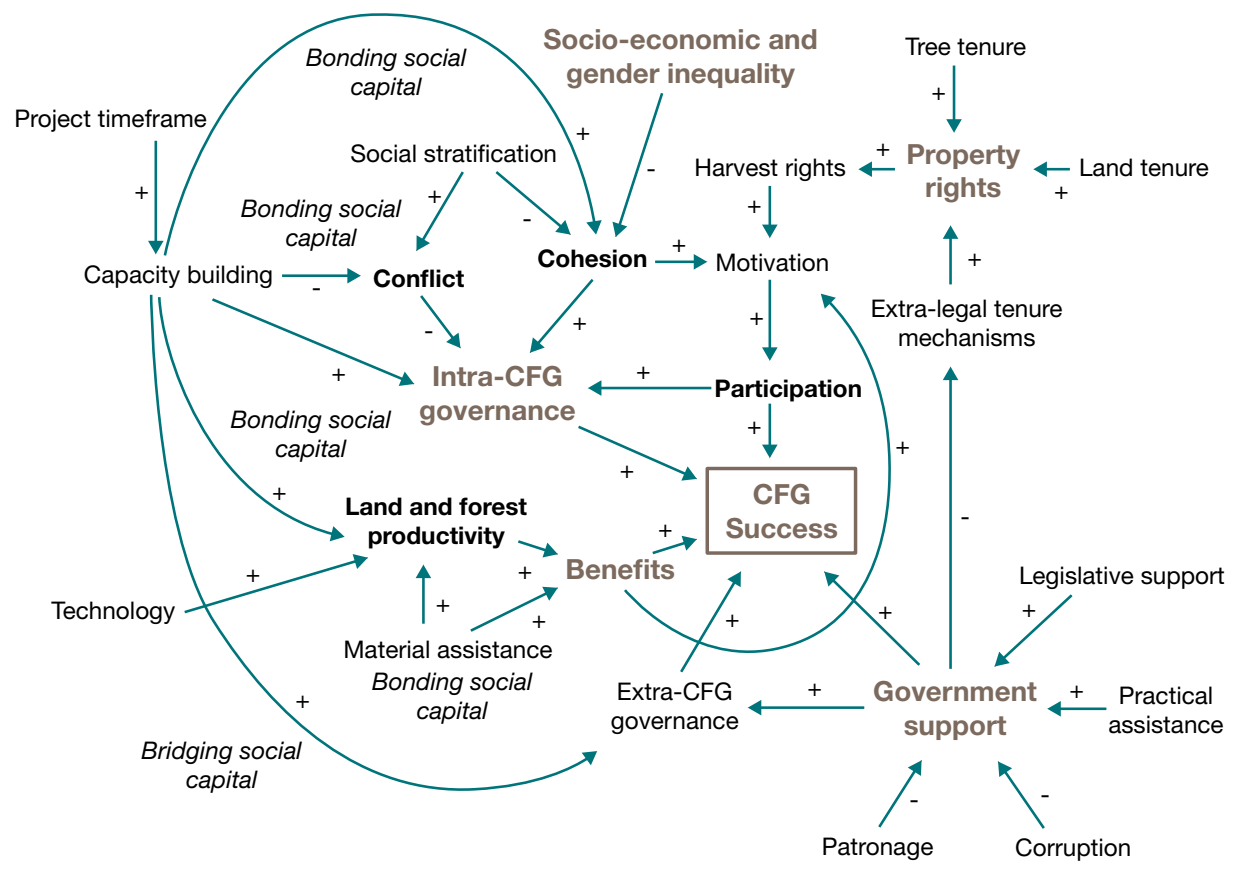

Source: Baynes, et al. (2015). 
The commonly reported drivers and indicators of successful reforestation, which also informed the design of the pilot community-based watershed rehabilitation project, are reported in Le, et al. (2012).

The design of the pilot community-based watershed rehabilitation project is also anchored on results of previous government reforestation projects. The problems and issues experienced and perceived by stakeholders in the implementation of past watershed rehabilitation projects in the Philippines (Israel \& Lintag, 2013) were also taken into account in the project design.

The design, implementation and monitoring of the pilot watershed rehabilitation project adopts a participatory approach. Stakeholders, including community leaders, land claimants or kaingin farmers, community residents, PO members and local DENR staff are involved in all stages of the project. The watershed rehabilitation planning process has included various meetings and workshops with stakeholders, which has guided the project design and included selection of tree and crop species, planting systems and agroforestry options. In addition, the consultations have identified forest-based livelihood projects and food security interventions.

A planning workshop with stakeholders provided crucial information regarding issues, problems and experiences of stakeholders in the NGP, and potential solutions to those problems (Table 2). However, it would appear that there is a recurrence of problems that led to unsuccessful outcomes in past reforestation programmes in the Philippines (Israel \& Lintag, 2013). The workshop also identified livelihood options. 
Table 2.

Summary of issues in implementing the NGP provided by $P O$ members, community residents, land claimants and local DENR personnel

\begin{tabular}{|c|c|c|}
\hline Activity & Experience or issue & Suggested intervention \\
\hline \multirow[t]{2}{*}{ Site selection } & No consultation with the community & $\begin{array}{l}\text { Public consultation } \\
\text { Information campaign about the } \\
\text { project } \\
\text { Survey site together with the PO }\end{array}$ \\
\hline & $\begin{array}{l}\text { No consultation and agreement with land } \\
\text { claimants }\end{array}$ & $\begin{array}{l}\text { Meeting with claimants to inform } \\
\text { them about the project } \\
\text { Encourage claimants to become } \\
\text { members of the PO }\end{array}$ \\
\hline \multirow[t]{4}{*}{$\begin{array}{l}\text { Organizational } \\
\text { preparation }\end{array}$} & $\begin{array}{l}\text { The PO was informed of the project but } \\
\text { there was no discussion on the roles the } \\
\text { PO would take on in the implementation, } \\
\text { conditions or benefits }\end{array}$ & $\begin{array}{l}\text { Information campaign is essential } \\
\text { to educate the PO about the } \\
\text { project, identify roles and explain } \\
\text { the benefits }\end{array}$ \\
\hline & $\begin{array}{l}\text { Only the PO officers were aware of the } \\
\text { project, not other members } \\
\text { No efforts to inform the PO members of } \\
\text { the potential benefits }\end{array}$ & $\begin{array}{l}\text { Ensure the PO officers } \\
\text { disseminate to members any } \\
\text { crucial information they learned } \\
\text { from the DENR } \\
\text { Regular meetings are necessary }\end{array}$ \\
\hline & PO members do not attend PO meetings & $\begin{array}{l}\text { Explain to PO members the } \\
\text { details of the project and the } \\
\text { benefits }\end{array}$ \\
\hline & $\begin{array}{l}\text { Claimants are not included in project } \\
\text { planning }\end{array}$ & $\begin{array}{l}\text { Identify roles of claimants and } \\
\text { include in the planning the project } \\
\text { implementation }\end{array}$ \\
\hline \multirow[t]{2}{*}{ Empowering the $\mathrm{PO}$} & $\begin{array}{l}\text { No community organizing occurs in the } \\
\text { NGP, unlike in previous reforestation } \\
\text { projects }\end{array}$ & $\begin{array}{l}\text { Re-organize the PO before the } \\
\text { start of the project }\end{array}$ \\
\hline & $\begin{array}{l}\text { Lack of identification on training needs of } \\
\text { PO members and absence of training and } \\
\text { capacity building }\end{array}$ & $\begin{array}{l}\text { Train PO members on } \\
\text { various aspects of the project } \\
\text { implementation } \\
\text { Train POs to manage livelihood } \\
\text { projects }\end{array}$ \\
\hline
\end{tabular}

\begin{tabular}{lll}
\hline $\begin{array}{l}\text { Implementing } \\
\text { livelihood projects }\end{array}$ & $\begin{array}{l}\text { There are no livelihood projects in the } \\
\text { NGP } \\
\text { PO generates revenue from seedling } \\
\text { production and plantation maintenance } \\
\text { but the budget for these activities is very } \\
\text { small }\end{array}$ & Provide livelihood to POs \\
\hline $\begin{array}{l}\text { Nursery seedling } \\
\text { production }\end{array}$ & PO not involved in species selection & $\begin{array}{l}\text { All members of the PO should } \\
\text { take part in the species selection }\end{array}$ \\
\hline & $\begin{array}{l}\text { Some seedlings were supplied by DENR } \\
\text { and the PO was only assigned to plant }\end{array}$ & $\begin{array}{l}\text { PO should produce the seedlings } \\
\text { to earn money from the project }\end{array}$ \\
\hline
\end{tabular}




\begin{tabular}{|c|c|c|}
\hline \multirow[t]{8}{*}{ Activity } & Experience or issue & Suggested intervention \\
\hline & $\begin{array}{l}\text { No training on high quality seedling } \\
\text { production }\end{array}$ & $\begin{array}{l}\text { The PO must be taught how to } \\
\text { produce high quality seedlings }\end{array}$ \\
\hline & $\begin{array}{l}\text { Seedlings were inspected by DENR but } \\
\text { low quality seedlings were accepted }\end{array}$ & $\begin{array}{l}\text { Low quality seedlings should not } \\
\text { be included } \\
\text { More stringent seedling quality } \\
\text { control e.g. nursery accreditation }\end{array}$ \\
\hline & High mortality of wildlings in nurseries & $\begin{array}{l}\text { Training on wildling collection, } \\
\text { handling and propagation in the } \\
\text { nursery }\end{array}$ \\
\hline & Insufficient seedling production period & $\begin{array}{l}\text { Seedling production must be } \\
\text { given a realistic timeline }\end{array}$ \\
\hline & $\begin{array}{l}\text { Limited sources of seeds and wildlings of } \\
\text { premium species }\end{array}$ & Inventory of mother trees \\
\hline & Delayed payment for seedlings & $\begin{array}{l}\text { Timely processing of documents } \\
\text { necessary to release the payment }\end{array}$ \\
\hline & $\begin{array}{l}\text { Only a few PO members were involved in } \\
\text { seedling production }\end{array}$ & $\begin{array}{l}\text { There must be equal distribution } \\
\text { of job opportunities especially in } \\
\text { seedling production where bulk of } \\
\text { the budget is allotted }\end{array}$ \\
\hline \multirow{5}{*}{$\begin{array}{l}\text { Plantation } \\
\text { establishment, } \\
\text { maintenance and } \\
\text { protection }\end{array}$} & $\begin{array}{l}\text { No designation of area for production, } \\
\text { protection and agroforestry }\end{array}$ & $\begin{array}{l}\text { Blocking must be done to guide } \\
\text { species selection and facilitate } \\
\text { plantation management }\end{array}$ \\
\hline & $\begin{array}{l}\text { Planting lay-out along the slope; hole } \\
\text { size just enough to accommodate the } \\
\text { root ball; plastic bags are sometimes not } \\
\text { removed }\end{array}$ & $\begin{array}{l}\text { Training on appropriate plantation } \\
\text { establishment, maintenance and } \\
\text { protection }\end{array}$ \\
\hline & $\begin{array}{l}\text { Firebreak was established but not } \\
\text { maintained due to lack of funds }\end{array}$ & $\begin{array}{l}\text { Increase funds for plantation } \\
\text { maintenance including firebreak } \\
\text { construction }\end{array}$ \\
\hline & $\begin{array}{l}\text { Weeding and strip brushing delayed due } \\
\text { to late release of funds }\end{array}$ & $\begin{array}{l}\text { Timely release of funds } \\
\text { Increase funds for plantation } \\
\text { maintenance } \\
\text { Weeding should remove roots of } \\
\text { weeds, not just cut the shoots }\end{array}$ \\
\hline & No fertilizer applied & $\begin{array}{l}\text { Increase funds to allow purchase } \\
\text { and application of fertilizer } \\
\text { Training on the production of } \\
\text { organic fertilizer, e.g. compost } \\
\text { and vermicast }\end{array}$ \\
\hline
\end{tabular}

No training on high quality seedling

Seedlings were inspected by DENR but low quality seedlings were accepted

High mortality of wildlings in nurseries

Insufficient seedling production period

Limited sources of seeds and wildlings of species

Delayed payment for seedlings

Only a few PO members were involved in

seedling production

Planting lay-out along the slope; hole size just enough to accommodate the root ball; plastic bags are sometimes not

Firebreak was established but not maintained due to lack of funds

Weeding and strip brushing delayed due to late release of funds and vermicast 
Table 2. (continued)

\begin{tabular}{lll}
\hline Activity & Experience or issue & Suggested intervention \\
& $\begin{array}{l}\text { Very small budget for plantation } \\
\text { maintenance }\end{array}$ & $\begin{array}{l}\text { Increase budget for plantation } \\
\text { maintenance }\end{array}$ \\
\hline Project monitoring & $\begin{array}{l}\text { Inappropriate basis for auditing of } \\
\text { reforestation success } \\
\text { Limited amount of funds to implement the } \\
\text { project and support effective monitoring of } \\
\text { established plantations }\end{array}$ & $\begin{array}{l}\text { The socioeconomic impact of } \\
\text { the programme should also be } \\
\text { included in the assessment rather } \\
\text { than focusing on the size of the } \\
\text { plantation }\end{array}$ \\
& $\begin{array}{l}\text { Adequate funds should be } \\
\text { provided and livelihood projects } \\
\text { must come with the reforestation } \\
\text { programme }\end{array}$ \\
\hline
\end{tabular}

The KFAI members were consulted on their most preferred forest-based livelihood projects (Table 3). Nursery seedling production was the top preference because there is a viable market for seedlings for the NGP and other government and private sector reforestation projects. Charcoal making had the second highest rating because of the presence of typhoon-damaged trees. Selling firewood and charcoal is an incomegenerating activity of upland communities in Biliran; several PO members having the skills to produce charcoal from wood. Furniture making ranked third because the PO has an Acacia mangium plantation under the CBFM programme which is a source of suitable furniture timber. Abaca production when trees are large enough to provide shade was also suggested as the fourth preference. The fifth most preferred option was the production of annual cash crops including vegetables and root crops.

\begin{tabular}{cll}
$\begin{array}{c}\text { Table 3. } \\
\text { List of livelihood } \\
\text { projects according } \\
\begin{array}{r}\text { to preference of PO } \\
\text { members and reasons } \\
\text { for choosing them }\end{array}\end{array}$ & Livelihood project & Reason \\
\cline { 2 - 3 } & 1. Seedling production & $\begin{array}{l}\text { Viable market because there are always reforestation projects being } \\
\text { implemented by government and private agencies }\end{array}$ \\
\cline { 2 - 3 } & 2. Charcoal production & $\begin{array}{l}\text { There is a market for charcoal, there are plenty of typhoon-damaged } \\
\text { trees, and charcoal is easy to produce and provides income readily }\end{array}$ \\
\cline { 2 - 3 } & $\begin{array}{ll}\text { There are mature trees for the PO to harvest; the market is available but } \\
\text { quite challenging to compete with other sellers }\end{array}$ \\
\cline { 2 - 3 } & $\begin{array}{l}\text { Viable market for abaca production, which maximizes growing space } \\
\text { in the plantation, contributes to weed control and reduces risk of crop } \\
\text { infestation }\end{array}$ \\
\hline production & $\begin{array}{l}\text { Vegetables and root crops are in demand hence easy to sell, there is } \\
\text { available space for planting and they provide early income as well as food }\end{array}$ \\
\hline
\end{tabular}


Aside from the workshop, a series of surveys was undertaken to gather baseline information regarding the socioeconomic status of the households in the community of Kawayanon. Meetings were also held with key DENR officials at the community and regional levels to gather information pertaining to policy and governance, and to identify support measures the DENR could provide in implementing watershed rehabilitation projects. A meeting with land claimants together with local DENR officials and officers of KFAI was held to discuss the roles of land claimants in the project. This meeting provided the opportunity for claimants to express their views and concerns regarding their land being included in the project site. The discussion resulted in the development of a memorandum of agreement (MOA) between the claimants and the PO setting out the rights, responsibilities and sharing of benefits between both parties.

A workshop bringing together the research team of the ACIAR Watershed Rehabilitation Project and staff members of the local DENR office was held to develop the implementation plan of the pilot watershed rehabilitation project. The plan was then presented to the stakeholders (KFAl members, community leaders, land claimants and DENR) during a workshop in Kawayanon for their deliberation, modification and approval. In general, the implementation plan was accepted and details of the project activities were approved.

\section{Pilot testing of intervention measures on the community-based watershed rehabilitation project}

A number of intervention measures (Table 4 and summarized below) were developed and implemented in the pilot community-based reforestation project.

Site selection: Selection of the pilot community-based reforestation site through consultations with key officials of the local DENR office, community leaders, PO members, land claimants and other stakeholders.

Organizational preparation: Information and education campaign to inform the community and adjacent areas about the project. Impress upon the PO their ownership of the project; not to view themselves as contractors. Workshops to identify the roles, rights and responsibilities of stakeholder groups including the PO, DENR, researchers of the ACIAR Watershed Rehabilitation Project, land claimants and community residents. Avoid corruption by designing check-and-balance mechanisms for financial transactions and regular presentation of financial reports. The extension officers are highly visible and provide constant support to the organization.

Rejuvenation of the PO: Assess the PO institution and the need to rejuvenate the group. The PO was previously organized but may require re-organization or rejuvenation. 
Rejuvenation includes renewal of membership, review and revision of by-laws, identification of new leaders to replace disinterested PO officers. This involves group deliberations, for which the presence of DENR and community organizers is essential.

Empowering the re-organized PO: Training and capacity-building activities to improve the capacity of the PO in mother tree selection and germplasm collection; high quality seedling production; and smallholder-based best practice in plantation establishment, maintenance and protection. Capacity building on record keeping and financial management, producing minutes of meetings, drafting PO resolutions for policy development, and implementation of livelihood projects. Extension officers to work closely with the $\mathrm{PO}$ to provide timely technical support to ensure the technologies conveyed during the training sessions are adopted.

Identification and implementation of livelihood projects for income and food security: Identify and design the most appropriate livelihood projects in terms of PO preferences, capability to implement such livelihood activities, and the market viability of products. Assess the training needs of the PO and implement training and capacitybuilding support to promote the sustainability of the livelihood projects. Support the PO in accessing markets for products.

Site preparation: Apply best management practice in site preparation. Design the planting area into blocks according to intended use of the plantation, i.e. production, protection and agroforestry zones. The production zone is intended for planting trees for timber production and the protection zone is for less premium species but with high environmental values. The agroforestry zone is for planting fruit trees and agricultural crops for food production and income generation.

Nursery seedling production: Species selection based on site characteristics and preferences of the $\mathrm{PO}$, land claimants and the community. The PO produces seedlings using best practice. Nursery seedling production as a livelihood project of the PO. Extension officers provide the necessary capacity-building activities and technical support to the PO. Inventory of plus trees (superior phenotypes) as germplasm sources from the natural forest and on farms. Development of a seedling quality control system to ensure only high quality seedlings are planted.

Plantation establishment: Application of best practice in plantation establishment and demonstration of appropriate methods of seedling transport to planting site, site preparation and planting. The extension officers assist and guide the $\mathrm{PO}$ in implementing best practice.

Plantation maintenance and protection: Apply best practice in plantation maintenance and protection and undertake information campaign in the community on 
the importance of maintaining and protecting the plantation. Timely provision of substantial funds for maintenance and protection of plantation including purchase of fertilizer, and construction of firebreak and lookout tower. Training on the identification and control of pests and diseases, and on post-planting silviculture. Sustainable livelihood project to provide income and support food security while managing and protecting the plantation. Appropriate information campaign for PO members to understand fully their ownership of the project rather than considering themselves as reforestation contractors.

Project monitoring: Establish permanent plots to monitor and record the survival and growth rates of seedlings. Surveys on the impact of the project on the technical knowledge and capability of the PO members, their socioeconomic status and improvement in the biophysical condition of the reforestation site. Extension officers to work closely with the community.

Policy development: Review of existing PO and DENR policies. Revise or develop new policies (local, regional and national) to support the sustainability of the watershed rehabilitation programme.

\begin{tabular}{|c|c|c|c|}
\hline Project phase & Issue or problem & $\begin{array}{l}\text { Cause of the issue or } \\
\text { problem }\end{array}$ & Intervention \\
\hline \multirow[t]{2}{*}{ Site selection } & $\begin{array}{l}\text { Inappropriate } \\
\text { site in terms of } \\
\text { biophysical and } \\
\text { social conditions }\end{array}$ & $\begin{array}{l}\text { Intervention of political } \\
\text { leaders }\end{array}$ & $\begin{array}{l}\text { Selection of the site should be } \\
\text { based on objectives rather than } \\
\text { to satisfy the requests of political } \\
\text { leaders }\end{array}$ \\
\hline & $\begin{array}{l}\text { Beneficiaries are } \\
\text { poorly selected }\end{array}$ & $\begin{array}{l}\text { Limited timeframe for } \\
\text { social preparation; no } \\
\text { funds for community } \\
\text { organizing }\end{array}$ & $\begin{array}{l}\text { Adequate timeframe to prepare } \\
\text { for programme implementation; } \\
\text { adequate resources to organize } \\
\text { the community }\end{array}$ \\
\hline \multirow[t]{2}{*}{$\begin{array}{l}\text { Organizational } \\
\text { preparation }\end{array}$} & $\begin{array}{l}\text { Unclear rights and } \\
\text { responsibilities of } \\
\text { stakeholders }\end{array}$ & $\begin{array}{l}\text { Lack of a sound } \\
\text { management plan; feeling } \\
\text { of being a contractor } \\
\text { rather than owner of the } \\
\text { project }\end{array}$ & $\begin{array}{l}\text { Management plan that clearly } \\
\text { indicates the rights and } \\
\text { responsibilities of stakeholders } \\
\text { including the PO and land } \\
\text { claimants }\end{array}$ \\
\hline & $\begin{array}{l}\text { Weak PO } \\
\text { leadership }\end{array}$ & $\begin{array}{l}\text { Inappropriate community } \\
\text { organizing; weak support } \\
\text { from supporting agencies; } \\
\text { lack of capacity building }\end{array}$ & $\begin{array}{l}\text { Capacity-building; strong support } \\
\text { and guidance from community } \\
\text { organizers }\end{array}$ \\
\hline $\begin{array}{l}\text { Species } \\
\text { selection }\end{array}$ & $\begin{array}{l}\text { Site-species } \\
\text { mismatch }\end{array}$ & $\begin{array}{l}\text { No consultation; absence } \\
\text { of long-term plan (no } \\
\text { zoning); limited germplasm } \\
\text { sources; limited seedling } \\
\text { production period; } \\
\text { delayed release of funds }\end{array}$ & $\begin{array}{l}\text { Site survey (vegetation and } \\
\text { site characteristics); PO should } \\
\text { also select the species to plant; } \\
\text { blocking must be done to guide } \\
\text { species selection and facilitate } \\
\text { plantation management }\end{array}$ \\
\hline
\end{tabular}

Table 4.

Issues and problems in implementing community-based reforestation programmes and corresponding interventions, included in the implementation plan of the pilot community-based reforestation project 
Table 4.

\section{Project phase Issue or problem Cause of the issue or} problem

\section{Nursery}

seedling

Low quality

production seedlings
Lack of knowledge and

germplasm sources skills; limited funds; limited

limited production period

delayed release of funds;

ineffective implementation

of seedling quality

control policy; seedlings

purchased from other

nurseries

\begin{tabular}{|c|c|c|c|}
\hline & $\begin{array}{l}\text { Lack of } \\
\text { participation of } \\
\text { members }\end{array}$ & $\begin{array}{l}\text { Only few members are } \\
\text { involved in seedling } \\
\text { production }\end{array}$ & $\begin{array}{l}\text { Equal distribution of job } \\
\text { opportunities and capacity to } \\
\text { benefit financially especially in } \\
\text { seedling production where bulk } \\
\text { of the budget is allotted }\end{array}$ \\
\hline \multirow[t]{4}{*}{$\begin{array}{l}\text { Plantation } \\
\text { establishment, } \\
\text { maintenance } \\
\text { and protection }\end{array}$} & $\begin{array}{l}\text { Planting in the } \\
\text { wrong season }\end{array}$ & $\begin{array}{l}\text { Limited germplasm } \\
\text { supply; delayed release } \\
\text { of funds }\end{array}$ & $\begin{array}{l}\text { Inventory of mother trees; } \\
\text { improve germplasm access; } \\
\text { timely release of funds so as not } \\
\text { to delay the implementation of } \\
\text { project activities e.g. seedling } \\
\text { production scheduling }\end{array}$ \\
\hline & $\begin{array}{l}\text { Inappropriate site } \\
\text { preparation }\end{array}$ & $\begin{array}{l}\text { Limited funds; lack of } \\
\text { knowledge on best } \\
\text { practice }\end{array}$ & $\begin{array}{l}\text { Training on appropriate plantation } \\
\text { establishment, maintenance and } \\
\text { protection }\end{array}$ \\
\hline & $\begin{array}{l}\text { Inappropriate } \\
\text { post-establishment } \\
\text { silviculture } \\
\text { including absence } \\
\text { of weeding and } \\
\text { fertilizer application }\end{array}$ & $\begin{array}{l}\text { Limited funds; lack of } \\
\text { community participation; } \\
\text { lack of knowledge on best } \\
\text { practice }\end{array}$ & $\begin{array}{l}\text { Training on appropriate plantation } \\
\text { establishment, maintenance and } \\
\text { protection; increase funds for } \\
\text { plantation maintenance including } \\
\text { firebreak construction; timely } \\
\text { release of funds; application of } \\
\text { appropriate amount of fertilizer }\end{array}$ \\
\hline & $\begin{array}{l}\text { Limited } \\
\text { participation and } \\
\text { involvement of } \\
\text { locals; only few } \\
\text { farmers maintain } \\
\text { and protect the } \\
\text { trees }\end{array}$ & $\begin{array}{l}\text { Inappropriate community } \\
\text { organizing; no } \\
\text { consultation with the } \\
\text { community; absence of } \\
\text { livelihood projects and } \\
\text { other socioeconomic } \\
\text { incentives }\end{array}$ & $\begin{array}{l}\text { Public consultation; there } \\
\text { must be equal distribution of } \\
\text { job opportunities especially in } \\
\text { seedling production where bulk } \\
\text { of the budget is allotted }\end{array}$ \\
\hline
\end{tabular}

Training on production of high quality seedlings; more stringent seedling quality control, e.g. nursery accreditation; inventory of mother trees; planting schedule to allow ample time for seedling production

Intervention 


\begin{tabular}{|c|c|c|c|}
\hline \multirow[t]{6}{*}{ Project phase } & Issue or problem & $\begin{array}{l}\text { Cause of the issue or } \\
\text { problem }\end{array}$ & Intervention \\
\hline & $\begin{array}{l}\text { Low seedling } \\
\text { survival rate }\end{array}$ & $\begin{array}{l}\text { Site-species mismatch; } \\
\text { low quality seedling; } \\
\text { inappropriate nursery, } \\
\text { planting and post- } \\
\text { planting silviculture; lack } \\
\text { of maintenance; seedling } \\
\text { damage during hauling; } \\
\text { delayed release of funds; } \\
\text { planting off season }\end{array}$ & $\begin{array}{l}\text { Appropriate site-species } \\
\text { matching using existing scientific } \\
\text { information and local knowledge; } \\
\text { seedling quality regulation; } \\
\text { training on best practice in } \\
\text { plantation establishment, } \\
\text { maintenance and protection }\end{array}$ \\
\hline & Pests and diseases & $\begin{array}{l}\text { Lack of knowledge } \\
\text { on pest and disease } \\
\text { identification and control; } \\
\text { limited monitoring of the } \\
\text { plantation }\end{array}$ & $\begin{array}{l}\text { Training to improve knowledge } \\
\text { on pest and disease identification } \\
\text { and control }\end{array}$ \\
\hline & Poaching of trees & $\begin{array}{l}\text { Limited or absence of } \\
\text { plantation monitoring; lack } \\
\text { of information campaign; } \\
\text { limited participation of the } \\
\text { community }\end{array}$ & $\begin{array}{l}\text { Collaboration with community } \\
\text { residents and leaders; barangay } \\
\text { policy to help protect the } \\
\text { plantation; information campaign } \\
\text { on importance of the project }\end{array}$ \\
\hline & $\begin{array}{l}\text { Damage of } \\
\text { plantation by stray } \\
\text { animals }\end{array}$ & $\begin{array}{l}\text { Lack of information } \\
\text { campaign; absence } \\
\text { of local policy; lack } \\
\text { of involvement and } \\
\text { participation of the } \\
\text { community }\end{array}$ & $\begin{array}{l}\text { Collaboration with community } \\
\text { residents and leaders; barangay } \\
\text { policy to help protect the } \\
\text { plantation; information campaign } \\
\text { on importance of the project }\end{array}$ \\
\hline & Forest fire & $\begin{array}{l}\text { No firebreak; insufficient } \\
\text { plantation monitoring and } \\
\text { maintenance }\end{array}$ & $\begin{array}{l}\text { Establishment of firebreak; } \\
\text { regular monitoring and } \\
\text { maintenance of plantation }\end{array}$ \\
\hline \multirow[t]{2}{*}{$\begin{array}{l}\text { Plantation } \\
\text { harvest and } \\
\text { utilization }\end{array}$} & $\begin{array}{l}\text { Unclear harvesting } \\
\text { policies }\end{array}$ & $\begin{array}{l}\text { Lack of sustained } \\
\text { information; lack of } \\
\text { long-term management } \\
\text { planning including zoning } \\
\text { according to plantation } \\
\text { use }\end{array}$ & $\begin{array}{l}\text { Development of long-term } \\
\text { project plan; zoning of plantation } \\
\text { to delineate production, } \\
\text { protection and agroforestry } \\
\text { zones; educate the PO members } \\
\text { on the harvesting process }\end{array}$ \\
\hline & Sharing of benefits & $\begin{array}{l}\text { Lack of organization and } \\
\text { internal policy on sharing } \\
\text { of benefits }\end{array}$ & $\begin{array}{l}\text { Develop internal policy regarding } \\
\text { the sharing of benefits among } \\
\text { PO members }\end{array}$ \\
\hline
\end{tabular}

Table 4.

Site-species mismatch;

ow quality seedling;

planting silviculture; lack mited monitoring of the

Limited or absence of

ation monitoring; lack

plantation; information campaign

plantation by stray

policy to help protect the

plantation; information campaign

of involvement and

community

firebreak; insufficient

tirebreak

regular monitoring and

Development of long-term

project plan; zoning of plantation

to delineate production,

protection and agroforestry

on the harvesting process

the sharing of benefits among 
Table 4. (continued)

\begin{tabular}{|c|c|}
\hline Project phase & Issue or problem \\
\hline $\begin{array}{l}\text { Implementing } \\
\text { livelihood } \\
\text { projects }\end{array}$ & $\begin{array}{l}\text { Inappropriate } \\
\text { livelihood projects }\end{array}$ \\
\hline
\end{tabular}

Cause of the issue or problem

Intervention

Livelihood that does not

Consultation with the $\mathrm{PO}$ and

match the preference

community; feasibility study

and capacity and

circumstance of the

PO; no consultation

with community and no

feasibility study

\begin{tabular}{llll}
\hline & $\begin{array}{l}\text { Unsustainable } \\
\text { livelihood projects }\end{array}$ & $\begin{array}{l}\text { Limited knowledge in } \\
\text { business ventures and } \\
\text { financial management }\end{array}$ & Training and capacity building \\
\hline $\begin{array}{l}\text { Project } \\
\text { monitoring }\end{array}$ & Corruption & $\begin{array}{l}\text { Improper auditing; lack } \\
\text { of transparency; weak } \\
\text { organizational structure }\end{array}$ & $\begin{array}{l}\text { Proper community organizing; } \\
\text { regular reporting of expenditures } \\
\text { and income to DENR and PO } \\
\text { members. POs accountable for } \\
\text { reporting to DENR as mandated } \\
\text { in the programme }\end{array}$ \\
\hline
\end{tabular}

Ineffective Unsupportive Assessment of policies, their

governance policy; loopholes in

implementation of policies

resulting in ineffectiveness

appropriateness, effectiveness

and implementation;

and corruption

improvement of implementation

of existing policies or formulation

of new policies

\begin{tabular}{|c|c|c|}
\hline $\begin{array}{l}\text { Limited support } \\
\text { from community } \\
\text { organizer }\end{array}$ & $\begin{array}{l}\text { Shortage of funds; } \\
\text { improper distribution of } \\
\text { community organiser's } \\
\text { time }\end{array}$ & $\begin{array}{l}\text { Increase budget for personnel; } \\
\text { capacity building of PO members } \\
\text { to operate even without the } \\
\text { extension officer }\end{array}$ \\
\hline $\begin{array}{l}\text { Failure to conduct } \\
\text { periodic monitoring }\end{array}$ & $\begin{array}{l}\text { Lack of funds; weak } \\
\text { community organizing and } \\
\text { capacity building }\end{array}$ & $\begin{array}{l}\text { Increase funds; improve capacity } \\
\text { of POs }\end{array}$ \\
\hline $\begin{array}{l}\text { Delayed release of } \\
\text { funds }\end{array}$ & Red tape and bureaucracy & $\begin{array}{l}\text { Improve capacity of PO to } \\
\text { prepare documents; strong } \\
\text { support from the extension } \\
\text { officer or local DENR staff }\end{array}$ \\
\hline $\begin{array}{l}\text { Inappropriate } \\
\text { funds }\end{array}$ & $\begin{array}{l}\text { Limited funds to } \\
\text { implement the project } \\
\text { and support effective } \\
\text { monitoring of established } \\
\text { plantations }\end{array}$ & $\begin{array}{l}\text { Adequate funds should be } \\
\text { provided and livelihood projects } \\
\text { must come with the reforestation } \\
\text { programme }\end{array}$ \\
\hline $\begin{array}{l}\text { Inappropriate } \\
\text { basis in auditing } \\
\text { of reforestation } \\
\text { success }\end{array}$ & $\begin{array}{l}\text { The size of area planted } \\
\text { is the basis for assessing } \\
\text { reforestation success }\end{array}$ & $\begin{array}{l}\text { The socioeconomic impact of } \\
\text { the programme should also } \\
\text { be included in the assessment } \\
\text { rather than focusing on the size } \\
\text { of the plantation }\end{array}$ \\
\hline
\end{tabular}




\section{Progress and impact of the pilot watershed rehabilitation project}

A year into implementing the pilot community-based reforestation project and substantial developments are evident. The pace, scope and cost-effectiveness of these developments are notably better than in most government reforestation sites in Biliran Province. The pilot-tested interventions and the way these interventions were implemented have proven to be effective in addressing the shortcomings of previous forest landscape restoration endeavours.

\section{Community organization}

The PO has been re-organized or rejuvenated, with the number of active members increased from three individuals to 30 families. A new set of officers was formed replacing those who were inactive, had migrated or decided not to continue. The set of officers was appointed by the PO members and witnessed by DENR officials.

With the support of the DENR and ACIAR Watershed Rehabilitation Project, the PO has developed local policies regarding membership agreements, management of the project and sharing of immediate and long-term project benefits. These policies have increased the interest of farmers to participate because of the guarantee of benefits from engaging in the project. Through the information and education campaign and capacity-building activities, the PO members have become fully aware of the project's objectives and their roles in the implementation, their rights, and the tangible and intangible benefits. From the previous concept of being a project contractor, the PO's ownership of the project is now instilled in the minds of the members.

The land claimants from the site that were a threat to project implementation have become members of the PO. Their farms were delineated and a MOA with the PO was established to recognize their claims. The MOA indicates that claimants will receive a share of the harvest of trees and agricultural crops on top of their share from being members of the organization. 
Figure 4 .
KFAI member marking the mother tree of a premium native timber species in the natural forest of the community (photo credit: Jufamar Fernandez)

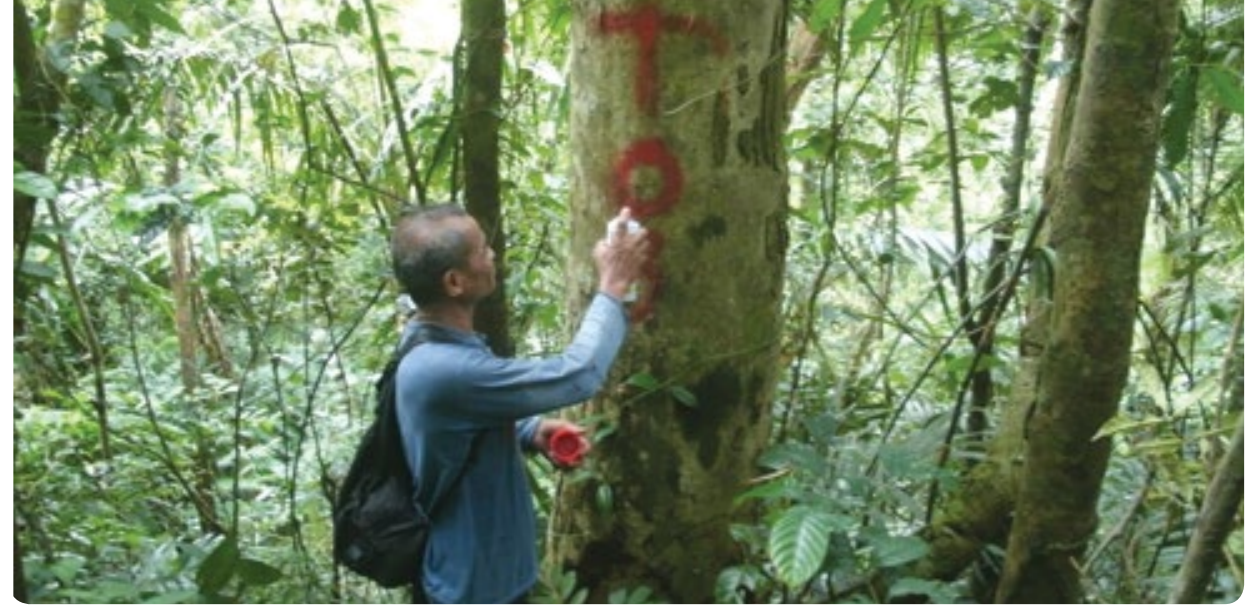

\section{Capacity development}

The capacity-building component of the project has considerably improved the technical knowledge and skills of the PO members. Through a series of handson training classes, the $\mathrm{PO}$ is now capable of inventorying and grading mother trees, a skill that is not common to many POs in the country or even among DENR personnel. They are now fully aware of the importance of using high quality seedlings and the characteristics these seedlings should possess, and have acquired the skills to produce high quality seedlings using smallholder-based cost-effective nursery techniques. The PO members have learned best-practice methods for site preparation and plantation establishment, including the appropriate size of planting holes, the correct method of planting seedlings and the process of checking and monitoring the planting process. They possess the knowledge of appropriate postplanting silviculture including the appropriate type and amount of fertilizer to apply and the application method. The PO has also developed skills in record keeping, financial management, producing reports and developing local resolutions for policy-making.

The extension officers have carried out continuous follow-up activities to ensure that technologies conveyed during training events and capacity-building activities have been adopted. This addressed the finding in previous reforestation programmes that one-off training events are ineffective in promoting technology adoption. 


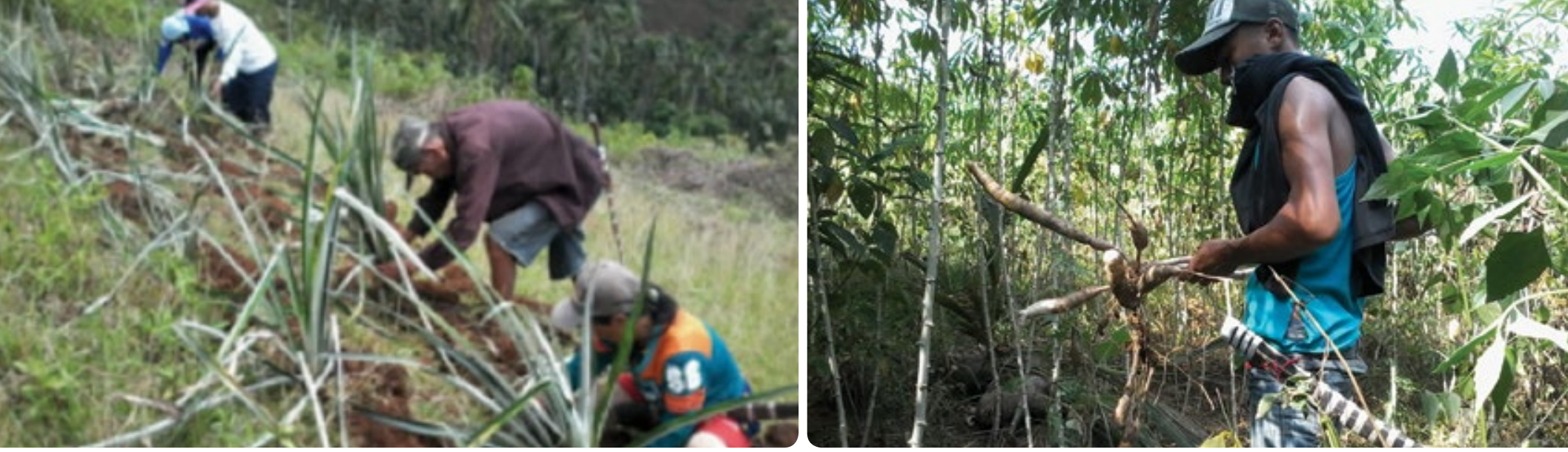

Improved supply of germplasm

With technical support from extension officers of the ACIAR Watershed Rehabilitation Project, KFAl members have carried out the inventory of plus trees (phenotypically superior seed-source trees) in the natural forest of Kawayanon (Figure 4). The PO has identified 300 plus trees of premium native species. The location of plus trees has been mapped and trees have been marked and labelled for easy identification. A mother tree conservation programme has been developed to protect the trees from illegal logging. Aside from providing germplasm for the reforestation activities of the $\mathrm{PO}$, the mother trees will generate income through the sale of high quality germplasm to other seedling producers.

Implementing livelihood projects

As the project is still in the early phase of operation, most income of the PO is derived from payment for services in implementing the pilot watershed rehabilitation project, particularly from seedling production, site preparation, and plantation establishment and protection. The income is not great but the PO members remain highly active in implementing the project, which suggests that their participation is not simply money driven. The PO has applied for nursery accreditation and passed the assessment carried out by local and regional DENR offices. This is a prerequisite for becoming an accredited seedling supplier for reforestation projects in the Philippines. Rows of Leucaena leucocephala and Acacia auriculiformis have been planted on the boundary of the plantation for production of wood for charcoal making, one of the priority livelihood activities identified. The PO has processed
Figure 5.

PO members planting pineapple in the newly developed agroforestry farm (a) and a land claimant who became member of the PO harvesting cassava planted in the firebreak (b).

(photo credit: Rogelio Tripoli) 


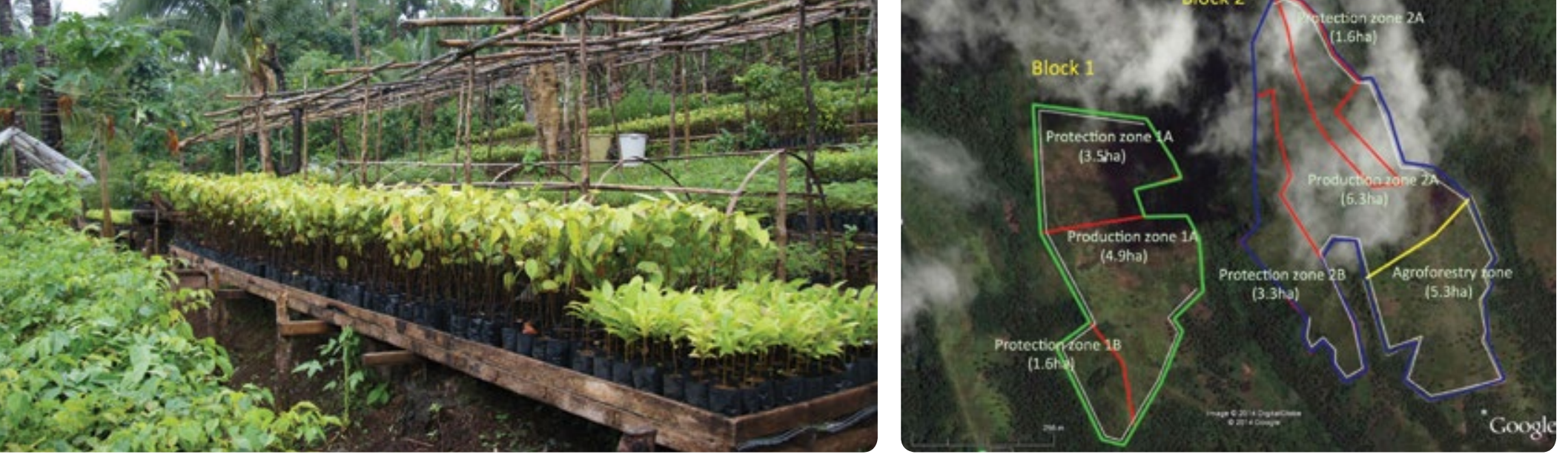

Figure 6. the application for the timber-harvesting permit to utilize the Acacia mangium trees that are

(left)

The low-cost nursery of the PO producing high quality seedlings (photo credit: Nestor Gregorio) remnants of the previous CRP. The timber will be used for furniture making, an additional livelihood activity.

The PO is starting up a vermiculture project to produce vermicast as organic fertilizer for the planted trees and also for sale to owners of plantations and implementers of reforestation projects in other areas.

Figure 7. (right) The layout of the project site showing the planting blocks (Site map courtesy of Jufamar Fernandez)

\section{Promoting food security}

An agroforestry zone within the reforestation site has been devoted to the planting of food crops, fruit trees and premium fast-growing timber species. This area is designed to help address food shortage and provide additional income to the PO while managing the trees. The PO together with the DENR and ACIAR Watershed Rehabilitation Project has developed the agroforestry farm design. Fruit tree species and agricultural crops were chosen based on PO preferences and suitability for the planting site. Through partnership with the DENR, the PO obtained funds to purchase carabao (water buffalo) used for cultivating the agroforestry farm. Funds were also used for acquiring high quality planting materials for agricultural crops and fruit trees. Figure 5a shows the newly planted pineapple in between strips planted with sweet potato and cassava in the agroforestry farm.

Less combustible crops including pineapple, cassava, taro and sweet potato are being planted on the firebreak to further food security measures and help reduce the cost of firebreak maintenance. The PO members have started harvesting agricultural crops planted in the firebreak (Figure 5b). Farm produce in excess of the food requirements of PO members are sold to provide additional income. 

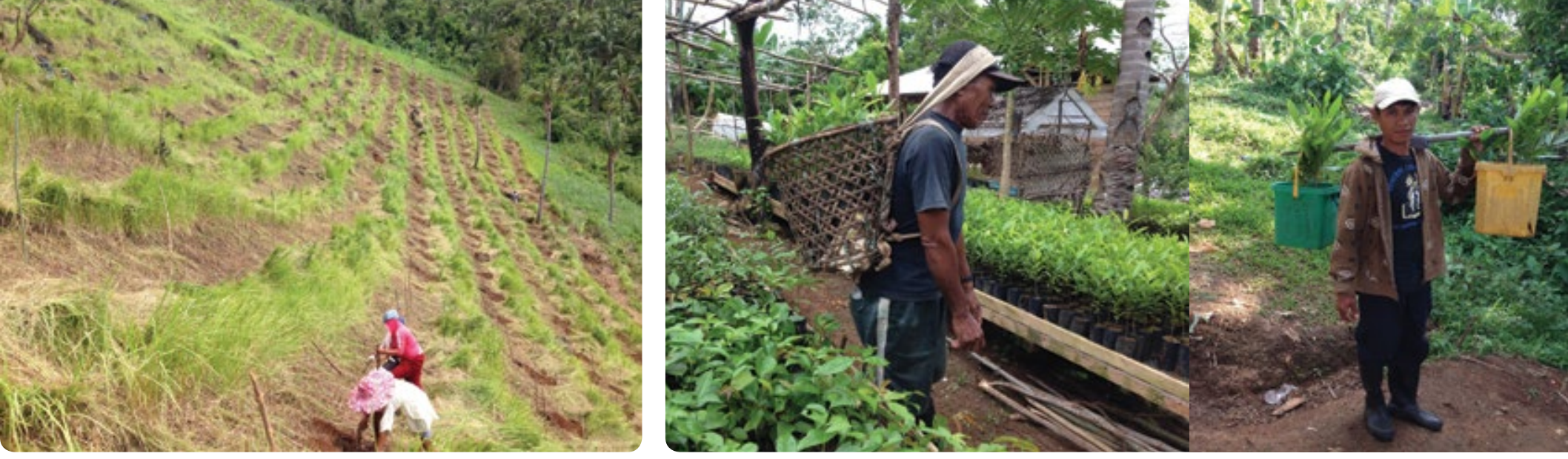

Species selection and production of high quality seedlings

Tree species for the pilot watershed rehabilitation were selected based on the preferences of the $\mathrm{PO}$ and suitability for the planting site. Through a series of training sessions, extension officers of the ACIAR Watershed Rehabilitation Project demonstrated smallholder-based production of high quality seedlings. The PO has constructed a low-cost nursery, which produces high quality seedlings (Figure 6). Elevated hardening beds have been used to produce sturdy seedlings. The nursery seedling production technologies of KFAl are being used as a model for the local DENR office to promote high quality seedling production in other communities in Biliran Province with NGP projects. A multipurpose building was constructed in the nursery and used for meetings and group gatherings.

Application of the best-practice method in site preparation

With technical support from extension officers of the ACIAR Watershed Rehabilitation Project and the local DENR office, the PO has divided the planting site into three zones - protection, production and agroforestry (Figure 7). The blocking guides plantation management, species selection and harvesting plan. The production zone is intended for planting trees for timber production and the protection zone is for less premium but highly ecologically important trees. The agroforestry zone is for the planting of fruit trees and agricultural crops for food production and income for the PO.

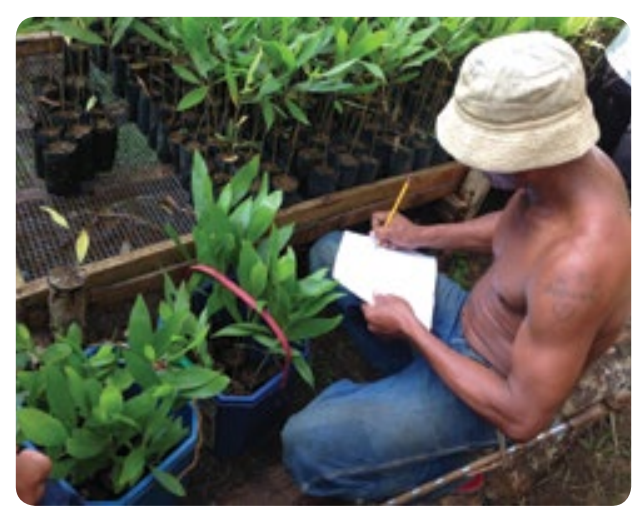

Figure 8.

(left)

KFAI members preparing the planting holes along the established planting lines (photo credit: Nestor Gregorio)

Figure 9.

(right)

Hauling techniques used by the PO to minimize seedling damage (photo credit: Nestor Gregorio)

Figure 10. A PO member recording the number of seedlings by species prior to seedling transport from the nursery to the planting site (photo credit: Nestor Gregorio) 
Figure 11.

Seedlings of Pterocarpus indicus, Acacia mangium and Calophyllum blancoi exhibiting vigorous growth at four months after planting (photo credit: Rogelio Tripoli)
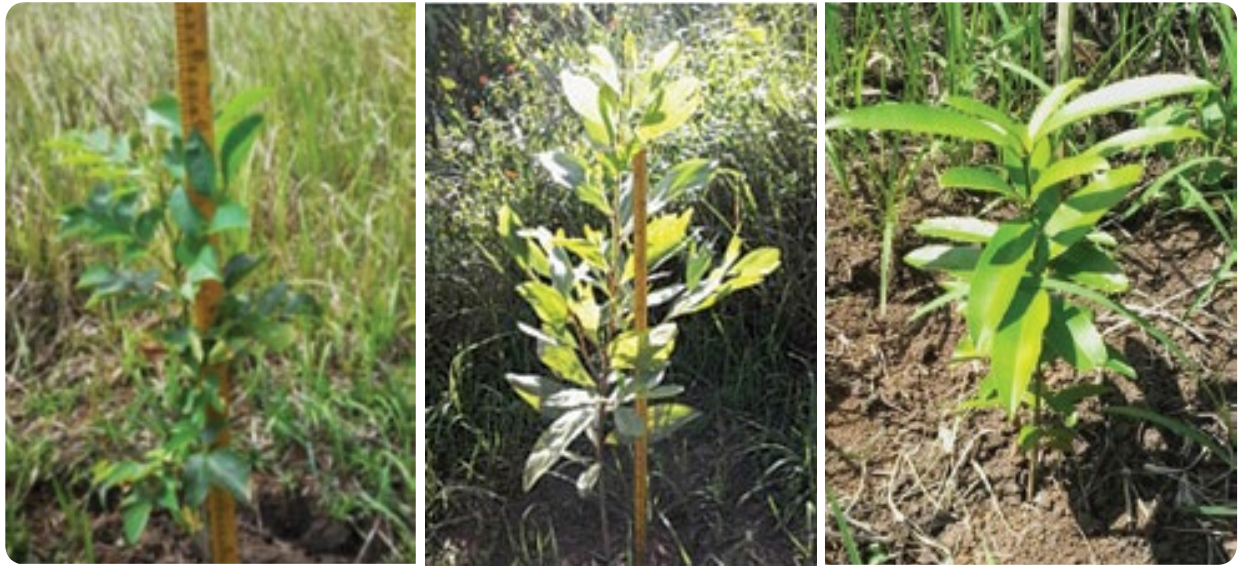

Planting lines across the slope were established to facilitate plantation maintenance activities and minimize soil erosion. Planting points were marked with pegs long enough for easy identification during planting. Planting spots were devoid of weeds over an approximately $1-\mathrm{m}$ radius. Figure 8 shows the site prepared for planting.

\section{Plantation establishment and appropriate post-planting silviculture}

Seedling damage when hauled from the nursery to the planting site is a major problem in most reforestation projects. A seedling transport system was developed to minimize damage. PO members used woven baskets and plastic containers to haul the seedlings (Figure 9). The name of the hauler, number of seedlings transported by species and seedling quality were recorded in the nursery (Figure 10). These were checked when the hauler reached the planting site. The checkers in the nursery and planting sites communicated using a two-way radio.

The PO adopted the use of large planting holes $\left(30 \mathrm{~cm}^{3}\right)$ to facilitate root system development and capture water during rain events. This technique produced a high survival rate of transplanted seedlings ( $90 \%$ four months after planting). Also, the growth of seedlings has been impressive - reaching an average height of $80 \mathrm{~cm}$ (an increase of about $50 \mathrm{~cm}$ ) in just four months after transplanting. The seedlings have also developed lush and vigorous shoots indicating their root systems have advanced rapidly (Figure 11).

Adequate NPK fertilizer is applied to boost seedling growth. The PO has commenced production of compost. A vermiculture system is planned to produce organic fertilizer for 
the transplanted seedlings and for sale. Removal of weeds around each seedling in a 1-m radius is carried out every three months.

The PO patrols the plantation daily to protect the plantation from fire, pests and diseases, and stray animals. The PO has also collaborated with community officials to develop an ordinance prohibiting pasturing of animals inside and near the plantation. The community leaders identified and designated a new community pasture site, which is relatively far from the plantation.

\section{Development of local policies and improving regional and national policies to support the forest landscape restoration programme}

A major reason for the low interest of $\mathrm{PO}$ members in sustaining their participation in previous forestry projects is the absence or unclear nature of $\mathrm{PO}$ polices regarding the sharing of benefits among members. In the pilot community-based watershed rehabilitation project the $\mathrm{PO}$, with the support of the DENR, has developed local policies about organizational membership, project management and sharing of benefits. Through collaboration with community leaders, community ordinances have been developed to help protect plantations from fire and grazing animals. PO members also receive individual certificates indicating their ownership and rights regarding the plantation.

The nursery and seedling quality assessment protocol promoted by the ACIAR Watershed Rehabilitation Project and pilot tested in the community-based reforestation project has been adopted at the local DENR office. A meeting with senior DENR officials was held to discuss the nationwide adoption of this protocol. Regular meetings with DENR at the provincial, regional and national levels are also carried out to convey salient findings of the project. These results are envisaged to pave the way for improving existing policies or developing new ones to improve the success of community-based forest restoration programmes in the Philippines. 


\section{Key initial findings in implementing the pilot watershed rehabilitation project}

Mobilizing smallholder upland communities to become partners in watershed rehabilitation and management is not straightforward. While a number of community-based forestry programmes in the Philippines appear to have sound objectives and excellent implementation plans, few have exhibited favourable results. The following are some of the key findings from the early phase of implementing the pilot community-based watershed rehabilitation project that will potentially address the shortcomings of previous communitybased reforestation programmes.

\section{Appropriate project design}

The previous community-based reforestation programmes in Kawayanon failed to be holistic and consider crucial aspects, for example the CRP failed to include livelihood and food security components. Although regarded as the most appropriate programme, implementation of CBFM was fraught with constraints. The UDP failed to address the technical limitations of smallholders and failed to consider their preferences in fruit tree selection. The NGP is constrained by social, economic and biophysical factors. These reforestation programmes provided lessons that were useful in designing the current pilot community-based watershed rehabilitation programme.

For a community-based watershed rehabilitation project to succeed, it should be timely and should match the needs and interests of the community. The project should consider community-based watershed rehabilitation as a system, which is composed of several interacting elements (including the biophysical, social, economic and policy environments). It should provide both short- and long-term benefits, particularly on economic and food security. Inputs from the smallholders are critical in designing the project. Also, the project should be informed from research results and knowledge generated from past watershed rehabilitation initiatives so that successful interventions are continued and failures are not repeated. 
The project design should have a long-term focus considering that it will take several years before trees reach harvestable age. For example, production, protection and agroforestry plots should be carefully selected before establishing the plantation; this will guide the species selection and management regimes. Most NGP plantings have failed to consider the multiple end uses of the plantation. The short-term objective of the programme (i.e. to establish the plantation) is achieved but the long-term goal to derive income from trees is jeopardized.

\section{Adequate social preparation}

The lack of social preparation including provision of information about the programme, and roles and rights of smallholders (not only PO members but community residents and land claimants) and benefits derived from the programme has been indicated by PO members as the main reason for their limited participation. The increased membership of KFAl and its strong commitment to the pilot watershed rehabilitation project has been attributed to a clear understanding of the project, the process of implementation and the multiple benefits to be derived from the project.

The assumption in NGP implementation that existing POs do not require organizing and capacity building appears incorrect. POs require re-organizing or at least rejuvenating before commencing the project to address any conflicts, issues and constraints encountered in previous projects. Community organizing is not a short-term one-off activity, as practised in most community-based projects, but a long-term process without a definite end point.

Training and capacity-building support is necessary to enhance the skills and knowledge of smallholders regarding best practices in implementing a watershed rehabilitation project. It is necessary that training and capacity-building activities be tailored to the information, skills and knowledge needs of stakeholders.

\section{Necessity for strong PO leadership}

Weak leadership was identified during the planning workshop and interviews with PO members as one of the reasons for the weakness of past watershed rehabilitation initiatives. Strong leadership is needed to motivate, mobilize and guide the organization to achieve the objectives of the project, and promote equity of social and economic benefits among PO members. Leaders should be identified by the people and not chosen by funding agencies. 


\section{Transparency in handling project funds}

A major reason why KFAl disbanded after a few months of implementing the CBFM project was corruption and lack of transparency of $\mathrm{PO}$ officials in the use of project funds. Regular meetings to present financial reports have been initiated in the implementation of the pilot project. Extension workers of the DENR are invited to attend and copies of financial reports are displayed in the PO meeting centre.

\section{Sustainable livelihood and food security measures}

Financial return and food security are prime motivators for KFAl members to engage in watershed rehabilitation projects. Recognizing that most $\mathrm{PO}$ members are severely resourceconstrained, livelihood projects to provide both immediate and long-term financial benefits and food supplies are highly important. Whenever included, livelihood projects often come after plantation establishment to support plantation maintenance, when project funds are exhausted. However, findings from the pilot watershed rehabilitation project indicate that it may be necessary for livelihood projects to be in place before commencing reforestation. Without substantial income during the early stage of the project, PO members resort to working in other areas rather than participating in project activities. A few members who have alternative sources of food and income remain active in the project implementation leaving most members not gaining from the social and economic benefits. This is the usual precursor of the $\mathrm{PO}$ disbanding.

Livelihood planning is essential to address the real needs of the people and, as evidenced from the UDP project, the PO members should be included in the planning process. Technical and marketing support is also important to promote sustainability of the livelihood project.

\section{Sufficient and timely release of project funds}

The PO members emphasized that their budget for implementation of the NGP project was very limited - constraining the adoption of best practice in watershed rehabilitation. Delayed release of funds added to the difficulty of timely implementation of project activities. For example, seedling production was often pushed towards the onset of the rainy season leaving the PO a maximum of three months to produce the seedlings. In order to satisfy the seedling height requirement of DENR, the PO resorted to using mature wildlings tall enough to pass the evaluation but with poorly developed root systems because of limited time in the nursery. This is a major reason for low seedling survival after transplanting. The limited funds also prevented the PO from providing adequate fertilizer, carrying out regular 
weeding and other important project activities. The amount of funds should be sufficient to support successful project operation, especially during the early years when livelihood activities are still developing.

\section{Adequate institutional arrangements and a supportive policy environment}

Smallholders are always concerned about their rights and benefits in engaging with government-led community-based programmes. As emphasized during the interviews with KFAI members, lack of appropriate institutional arrangements and limited understanding of their rights, roles and benefits have undermined interest in participating in previous programmes. The lack of appropriate arrangements also prevented land claimants from participating. It is imperative that institutional arrangements are in place that will ensure smallholder partners realize the sustained benefits of participation. A policy environment (local, regional and national) that will provide support in achieving the objectives of the programme is essential.

\section{Security of land tenure}

Security of land tenure is a major issue in promoting community-based forestry projects using timberland (forestland or public land). Land tenure often equates to tree and crop tenure, which is largely connected to food security and economic returns from the project. In the pilot watershed rehabilitation project, the PO has established tenure security of the land for 25 years with the opportunity to renew for another 25 years. The land claimants, although not possessing a legal instrument for using the land, cannot be simply evicted from the site. An official agreement signed by land claimants and PO officials and witnessed by the DENR respecting the land claims of the farmers, the responsibilities and roles of each party, and the sharing of benefits from the project has been developed.

\section{Presence of extension officers}

Extension officers play a crucial role in organizing the community, providing training and promoting capacity building, and guiding the PO to achieve the objectives of the programme. KFAl members pointed out that limited guidance and participation of extension officers was one of the reasons for the disbandment of the group during previous projects. It was noted that the pace of operation, particularly during the early stage of the pilot watershed rehabilitation project implementation, and the motivation of the PO members to carry out the project was largely influenced by the presence of extension workers. 
Extension officers were also necessary in following up on the adoption of technologies conveyed during training activities. Investigations of training and extension activities associated with watershed rehabilitation projects indicated that training classes were usually carried out as one-time events, without follow-up to address constraints in the adoption of technologies. The extension workers of the ACIAR Watershed Rehabilitation Project assisted the PO for several months in community organizing, training and capacity building and follow-up activities, conflict resolution, and in acting as a third party reviewing financial reports of the programme's operation.

\section{Women at the forefront in watershed rehabilitation project}

Women have been important in implementing watershed rehabilitation initiatives. In most reforestation projects, involvement of women is limited to seedling production, weeding and other relatively light activities. However, the case of the pilot watershed rehabilitation showed women leading the establishment of the plantation including site preparation, hole digging, hauling of seedlings to the planting site (a 2-km uphill climb), planting of seedlings and maintenance of the plantation. About $70 \%$ of PO members involved in daily project operations are women (see Figure 12). When livelihood activities are in the initial stage and income from early phase project activities is relatively low for supporting the basic needs of families, husbands engage in jobs outside the project to satisfy the subsistence needs of the family. It is envisaged that once financial returns from livelihood projects become significant, the involvement of male members will increase.

Figure 12.

The PO members discussing the financial report and project activities (note the proportion of women compared with men) (photo credit: Rogelio Tripoli)

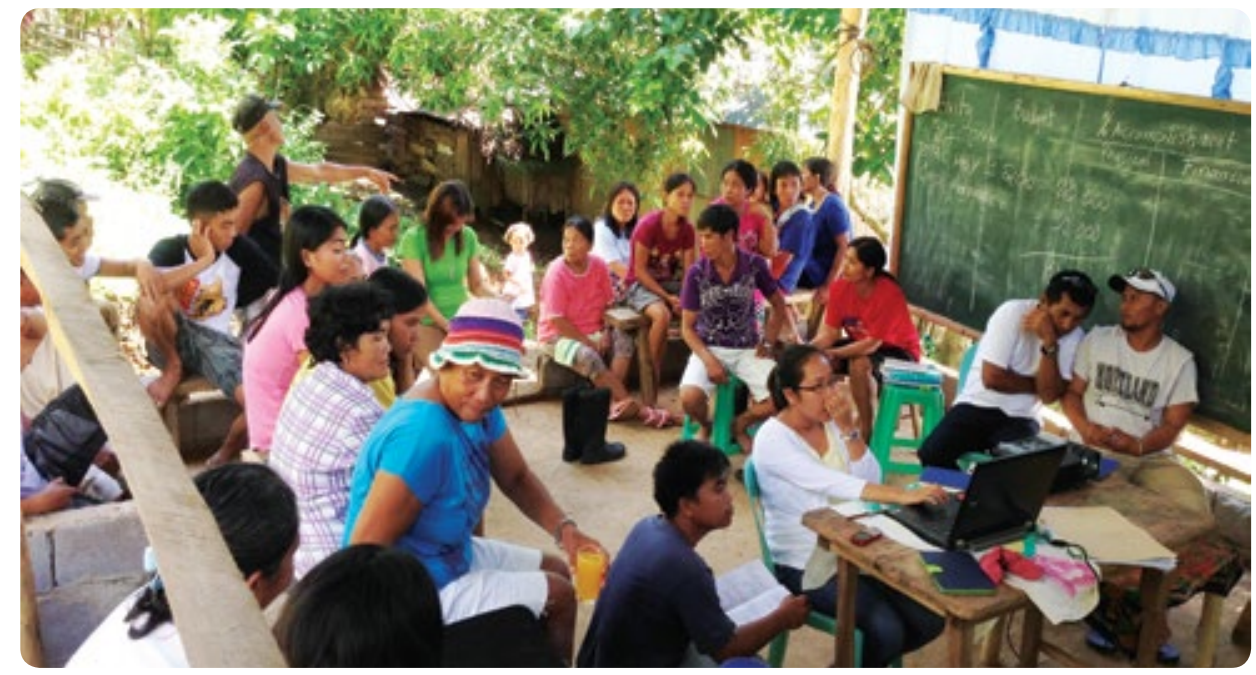




\section{Conclusion}

Key to the success for people-based forest landscape restoration programmes is addressing socioeconomic and food security issues of smallholder farmers. The ecological reason for reforestation of denuded uplands is widely understood. However, when a reforestation programme does not provide short- and long-term financial benefits and is in conflict with smallholders' subsistence farming activities in terms of time, labour and use of the land, the programme is unlikely to succeed.

The Philippines has a long history of undertaking community-based watershed rehabilitation programmes. Programme names and implementation strategies have changed but their objectives have remained similar. Accordingly, the concept of a community-based reforestation programme is not new in that there has been a plethora of community-based forest landscape restoration models, which also addressed food security and poverty issues. For example, a similar approach has also been implemented in tropical countries including Indonesia, Thailand and Nepal. However, our case study has proven that designing and implementing a community-based FLR requires a holistic view of the FLR systems and the application of an integrative systems approach to identifying and implementing the interventions. The factors contributing to mixed results of communitybased forestry are complicated and designing and implementing interventions is equally difficult. A systems approach to understanding causalities and designing interventions is needed. Unfortunately, most reforestation programmes failed to take this holistic view of the highly complex community-based forestry system. The application of a genuine participatory process at all levels of the programme and use of evidence and learning from past FLR interventions and research undertakings is also paramount. 


\section{References}

Amacher, G., Cruz, W., Grebner, D. and Hyde, W. (1998). 'Environmental motivations for migration: Population pressure, poverty and deforestation in the Philippines'. Land Economics 74(1):92-101.

ADB (1994). Asian Development Bank Approves New Forestry Policy for Asia-Pacific Region. Manila, 6 March 1994.

Bautista, G.M. (1990). 'The forestry crisis in the Philippines: Nature, causes and issues'. The Developing Economies 28(1):67-94.

Baynes, J., Herbohn, J., Smith, C., Fisher, R. and Bray, D. (2015). 'Key factors which influence the success of community forestry in developing countries'. Global Environmental Change 35:226-238.

Baynes, J., Herbohn, J., Gregorio, N. and Fernandez, J. (2014). 'How useful are small stands of low quality timber?'. Small-scale Forestry 14:193-204.

Baynes, J., Herbohn, J.L. and Russell, I. (2011a). 'The influence of farmers' mental models on an agroforestry extension program in the Philippines'. Small-scale Forestry 10(3):377-387.

Baynes, J., Herbohn, J.L., Russell, I. and Smith, C. (2011b). 'Bringing agroforestry technology to farmers' in the Philippines: Identifying constraints to the success of extension activities using systems modelling'. Small-scale Forestry 10(3):357-376.

Bersales, L.G.S. (2015). Total number of Barangays still stands at 42,029 as of First Quarter of 2015. PSA-NSCB press release. Available: http://nap.psa.gov.ph/pressreleases/2015/PR-2015_18May_psgc.asp [accessed 19 August 2015].

Borlagdan, S.B., Bautista, G., Bernasor, S., Quiroz, T., Ramirez, M.A. and Antolihao, L. (2000). Six Case Studies of Community-Based Forest Resource Management in the Philippines. Report submitted to the Ford Foundation by the Institute of Philippine Culture, Ateneo de Manila University, Quezon City.

Cabrido, C. (1985). 'An assessment of national soil erosion control management programs in the Philippines'. In: Craswell, E., et al. (eds), Soil Erosion Management. Los Banos, Laguna, Philippines: PCARRD.

Carandang, A., Dizon, J. and Pulhin, J. (2010). 'Promoting sustainable forest management through community forestry in the Philippines'. In: Mery, G., et al. (eds) Forests and Society - Responding to Global Drivers of Change, 509pp. IUFRO World Series Volume 25. Vienna.

Contreras-Hermosilla, A. (2000). The underlying causes of forest decline. CIFOR Occasional Paper No. 30. Indonesia. Center for International Forestry Research.

Deininger, K.W. and Minten, B. (1996). Poverty, policies, and deforestation: The case of Mexico. PEG Working Paper. Washington, DC: World Bank.

DENR (2015). Philippine Forestry Statistics. Available: http://forestry.denr.gov.ph/PFS2013.pdf [accessed 16 August 2015].

Ekoko, F. (1996). Poverty and deforestation. UNU/IAS Working Paper No. 18.

Emtage, N. (2004). 'An Investigation of the Social and Economic Factors Affecting the Development of Small-scale Forestry in Leyte Province, the Philippines', PhD thesis. University of Queensland, Brisbane: School of Natural and Rural Systems Management. 
Eslava, F. (2004). 'Community forestry in the Philippines: A country report'. In: Sim, H., Appanah, S. and Lu, W. (eds) Forests for Poverty Reduction: Can Community Forestry Make Money? Bangkok: Food and Agriculture Organization of the United Nations.

Espiritu, N.O., Casin, M.C.S. and Camacho, S.C. (2010). 'Development pathways in the Philippine uplands: Impacts and influences on forest resource management and human well-being'. Asian Journal of Agriculture and Development $7(2): 27-47$.

Estoria, E. (2004). 'The performance of community organisers in promotion of community forestry in Leyte Province, Philippines'. Small-scale Forestry 3 (3):363-384.

FAO (1978). Forestry for Local Community Development. FAO Forestry Paper No. 7. Rome: Food and Agricultural Organization of the United Nations.

FAO (1997). State of the World's Forests. Rome: Food and Agriculture Organization of the United Nations.

Gooddive (2015). Leyte Island Map. Available: http://www.gooddive.com/philippines-diving/leyte-island-map.htm [accessed 16 September 2015].

Gregorio, N.O., Harrison, S.R. and Herbohn, J.L. (2008). 'Enhancing Tree Seedling Supply to Smallholders in Leyte Province, Philippines: An Evaluation of the Production System of the Government Nursery Sector and Support to Smallholder Tree Farmers'. Small-scale Forestry 7(3-4):245-261.

Gregorio, N.O., Herbohn, J.L. and Vanclay, J.K. (2012). 'Developing establishment guidelines for Shorea palosapis in smallholder plantings in the Philippines'. International Forestry Review 14(4):492-501.

Gregorio, N.O., Herbohn, J.L. and Harrison, S.R. (2015). 'A systems approach to improving the quality of seedlings for reforestation, agroforestry and tree farming in the Philippines'. Land Use Policy 47:29-41.

Guiang, E.S., Borlagdan, S.B. and Pulhin, J.M. (2001). Community-based forest management in the Philippines: a preliminary assessment. Project Report. Ateneo de Manila University, Quezon City: Institute of Philippine Culture.

Harrison, S.R., Gregorio, N.O. and Herbohn, J.L. (2008). 'A Critical Overview of Forestry Seedling Production Policies and Practices in Relation to Smallholder Forestry in Developing Countries'. Small-scale Forestry 7(3-4):207-23.

Heaney L. and Mittermeier R. (1997). 'The Philippines'. In: Mittermeier R., et al. (eds.) Megadiversity: Earth's Biologically Wealthiest Nations. Mexico, pp. 236-255.

Herbohn, J., Vanclay, J., Nguyen, H., Le, H.D., Baynes, J. Harrison, S.R., Cedamon, E., Smith, C., Firn, J., Gregorio, N.O. and Mangaoang, E. (2014). 'Inventory procedures for smallholder and community woodlots in the Philippines: Methods, initial findings and insights'. Small-scale Forestry 13:79-100.

IUCN (2015). Bonn Challenge. Gland, Switzerland; International Union for Conservation of Nature. Available: http://www. bonnchallenge.org/ [accessed 22 October 2015].

Israel, D. and Lintag, J. (2013). Assessment of the Efficiency and Effectiveness of the Reforestation Program of the Department of Environment and Natural Resources. Final report. Manila: Philippine Institute of Development Studies.

Jensen, C. (2003). 'Development assistance to upland communities in the Philippines'. In: Developing Mechanisms For Rewarding The Upland Poor In Asia For Environmental Services They Provide. Bogor, Indonesia: World Agroforestry Centre. 
Kerr, R., Bindlos, J., Jealous, V., Liou, C. and Looby, M. (2000). The Philippines, 7th edition. Melbourne, Australia: Lonely Planet Publications, pp. 24-28.

Lasco, R., Visco, R. and Pulhin, J. (2001). 'Formation and transformation of secondary forests in the Philippines'. Journal of Tropical Forest Science. 13: 652-670.

Le, H.D., Smith, C. and Herbohn, J. (2015). 'Identifying interactions among reforestation success drivers: A case study from the Philippines'. Ecological Modelling 316: 62-77.

Le, H.D., Smith, C. and Herbohn, J.L. (2014). 'What drives the success of reforestation projects in tropical developing countries? The case of the Philippines'. Global Environmental Change 24:334-348.

Le, H.D., Smith, C., Herbohn, J. and Harrison, S. (2012). 'More than just trees: Assessing reforestation success in tropical developing countries'. Journal of Rural Studies 28:5-19.

LGU-Biliran (2015). Province of Biliran. Available: https://en.wikipedia.org/wiki/Biliran\#cite_note-8 [accessed 22 October 2015].

NSCB (2015). Poverty Statistics. National Statistics Coordination Board. Available: http://www.nscb.gov.ph/poverty/

NSCB (2013). Poverty Statistics. Ranking of cities and municipalities by poverty incidence in 2009. National Statistics Coordination Board. Available: http://www.nscb.gov.ph/ru8/poverty/Region8_Poverty_Incidence_2009/Municipal_ Poverty_Incidence_Region8.htm

Nguyen, H., Herbohn, J., Firn, J. and Lamb, D. (2012). 'Biodiversity-production relationships in small-scale mixedspecies plantations using native species in Leyte Province, Philippines'. Forest Ecology and Management 274:81-90.

Nguyen, H., Firn, J., Lamb, D. and Herbohn, J. (2014a). 'Wood density: a tool to find complimentary species for the design of mixed species plantations'. Forest Ecology and Management 334:106-113.

Nguyen, H., Lamb, D., Herbohn, J., Firn, J. (2014b). 'Designing Mixed Species Tree Plantations for the Tropics: Balancing Ecological Attributes of Species with Landholder Preferences in the Philippines'. PLoS ONE 9(4): e95267.

Owl and Mouse (2015). Map of the Philippines. Owl and Mouse Educational Software. Available: http://www. yourchildlearns.com/online-atlas/philippines-map.htm [accessed 10 September 2015].

Polinar, B. (2015). Personal communication, 10 February 2015. Forester, DENR-PENRO, Naval, Biliran.

Ptaff, A., Kerr, S., Cavatassi, R., Davis, B., Lipper, L., Sanchez, A. and Timmins, J. (2004). Effects of poverty on deforestation: Distinguishing behaviour from location. ESA Working Paper No. 04-19. Rome: Food and Agricultural Organization of the United Nations.

Pulhin, J.M. (1997). 'Trends, issues and challenges', in V. Lang and J. Bornemier (eds) Community Forestry at a Crossroad: Reflections and Future Directions in the Development of Community Forest, Regional Community Forestry Training Centre, Bangkok, pp. 201-215.

Pulhin, J.M., et al. (2006). 'Historical Overview'. In: Chokkalingam, U., Carandang, A.P., Pulhin, J.M., Lasco, R.D., Peras, R.J.J. and Toma, T. (eds) One century of forest rehabilitation in the Philippines: Approaches, outcomes and lessons. Bogor, Indonesia: World Agroforestry Centre, pp. 5-41.

Pulhin, J., Inoue, M. and Enters, T. (2007). 'Three decades of community-based forest management in the Philippines: Emerging lessons for sustainable and equitable forest management'. International Forestry Review 9(4):865-883.

Rebugio, L.L., Pulhin, J.M., Carandang, A.P., Peralta, E.O., Camacho, L.D. and Bantayan, N.C. (2007). 
'Forest Restoration and Rehabilitation in the Philippines'. International Union of Forest Research Organizations (IUFRO) World Series Vol. 20-I, Keep Asia Green, 'Southeast Asia'. Volume I. Ed. Don Koo Lee.

Sajise, P.E. (1998), 'Forest policies in the Philippines: a winding trail towards participatory sustainable development'. In: A Step Towards Forest Conservation Strategy: Current Status on Forests in the Asia-Pacific Region, Interim Report. Tokyo: The Institute of Global Environmental Strategies (IGES).

Sikor, T., Gritten, D., Atkinson, J., Huy, B., Dahal, G., Duangsathaporn, K., Phanvilay, K., Maryudi, A., Pulhin, J., Ramirez, M., Win, S., Toh, S., Vaz, J., Sokchea, T., Marona, S. and Yaqiao, Z. (2013). Community Forestry in Asia and he Pacific: Pathway to Inclusive Development. Bangkok: RECOFTC - The Centre for People and Forests.

Thomas, S., Dargusch, P., Harrison, S. and Herbohn, J. (2010). 'Why are there so few afforestation and reforestation Clean Development Mechanism projects?' Land Use Policy 27:880-887.

Tucker, R.P. (1988). 'The commercial timber economy under two colonial regimes in Asia'. In: Dargavel, J., Dixon, K. and Semple, N. (eds) Changing tropical forests: historical perspectives on today's challenges in Asia, Australasia and Oceania. Canberra: Centre for Resource and Environmental Studies, pp. 219-229.

Uitamo, E. (1996). 'Land use history of the Philippines'. In: Palo, M. and Mery, G. (eds) Sustainable Forestry Challenges for Developing Countries. Dordrecht, Netherlands: Kluwer Academic Publishers, pp. 141-156. 



\section{IUCN}

INTERNATIONAL UNION FOR CONSERVATION OF NATURE

WORLD HEADQUARTERS

Rue Mauverney 28

1196 Gland, Switzerland

Tel +41 229990000

Fax +41 229990002

www.iucn.org

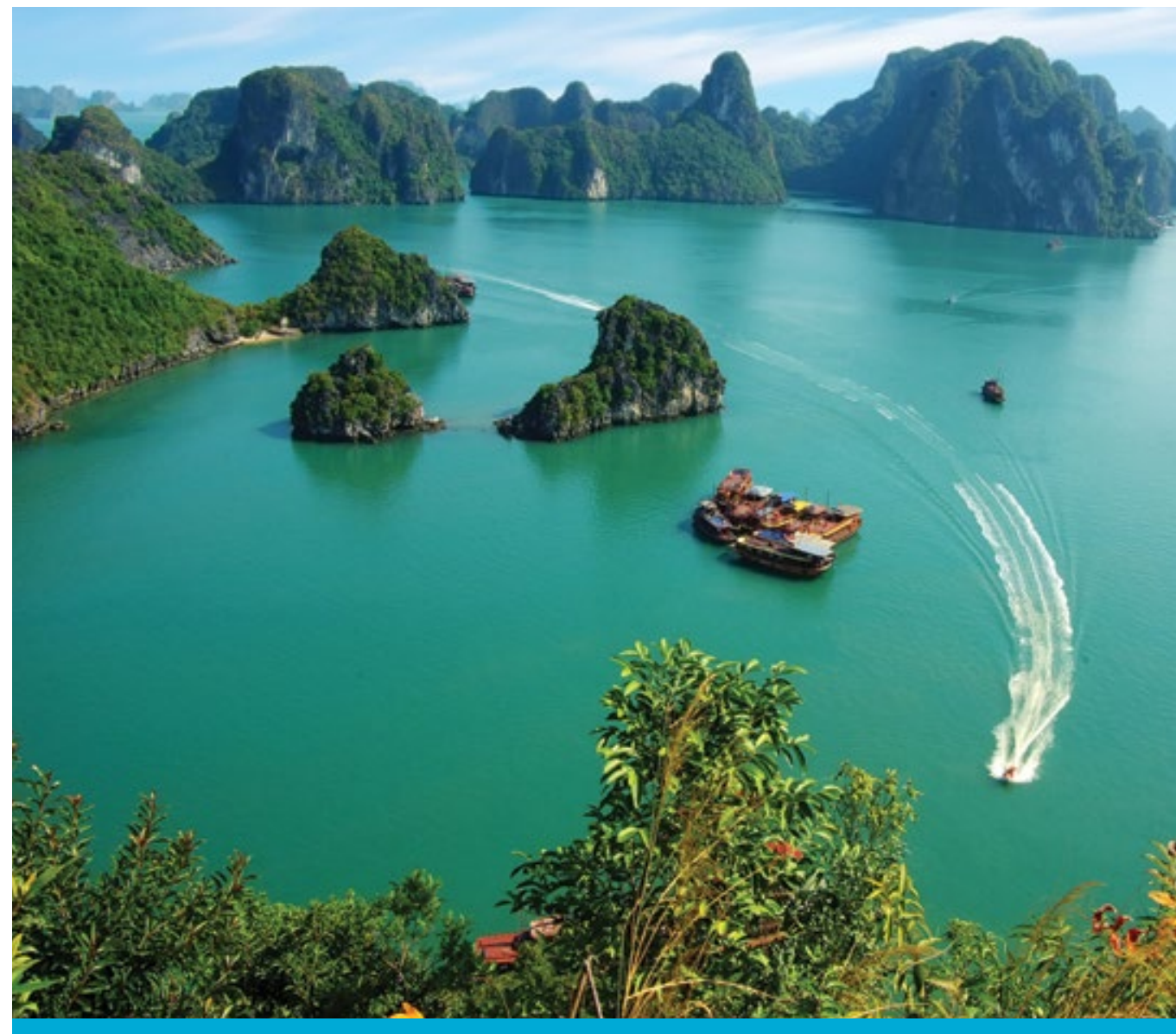

